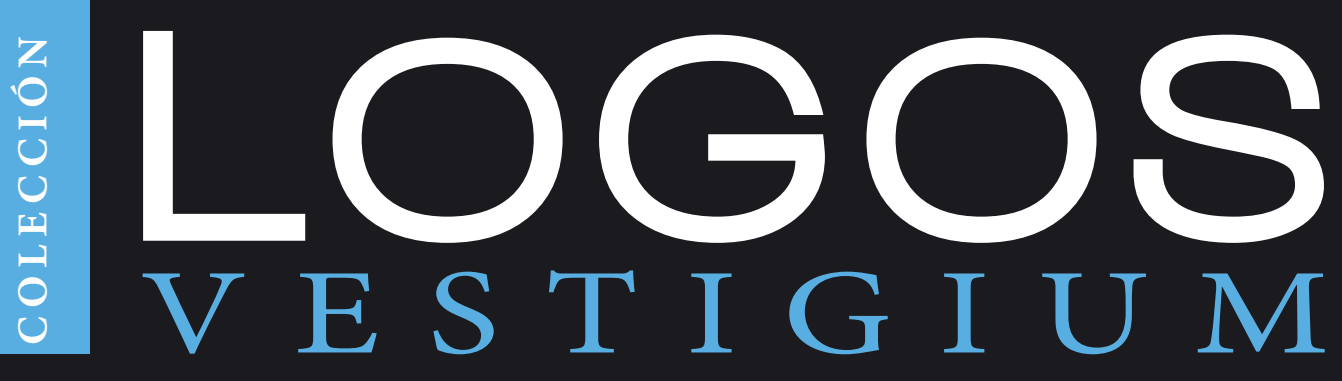

\title{
La vigencia del contrato psicológico: Aproximaciones teoricas y empíricas desde las Américas
}

Carlos-María Alcover (ed.), Sigmar Malvezzi, Juan Javier Vesga R., Rafael Chiuzi, Roberto O. Díaz-Juarbe, Sonia Maria Guedes Gondim, Mino Correia Rios, Mónica García-Rubiano, Carlos Forero-Aponte, Emmanuel Martínez-Mejia, Erika Mariana Ascencio Cabrera, Estefanía Aponte-Restrepo, Álvaro Giovanni Gonzallez- Herrera

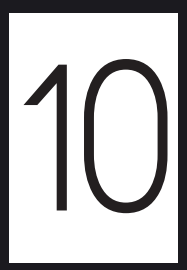




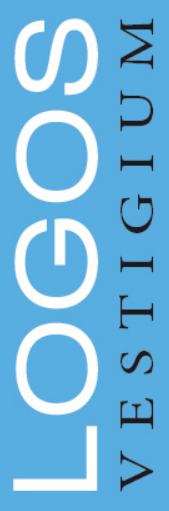

Carlos Forero-Aponte

Profesor universitario. Licenciado y Magíster en Psicología por la Universidad Católica de Colombia. $\mathrm{PhD}$ student Doctorate in Psychology, Universidad de La Laguna. carlosforeroaponte@gmail.com

\section{Emmanuel Martínez-Mejía}

Profesor investigador en la Facultad de Psicología de la UNAM y miembro del Sistema Nacional de Investigadores de CONACyT (México). Director Científico de Investigación en Psicología Organizacional S.C. emmanuel.martinez.mejia@comunidad.unam.mx

\section{Erika Mariana Ascencio Cabrera}

Gerente de proyectos en Investigación en Psicología Organizacional S.C. Licenciada en Pedagogía por la Universidad Nacional Autónoma de México. mariana@iporganizacional.com

\section{Estefanía Aponte-Restrepo}

Psicóloga egresada de la Fundación Universitaria Konrad Lorenz (FUKL), Colombia. Apoya la gestión de los procesos académicos y administrativos de la Facultad de Psicología de la FUKL. estefania.aponter@konradlorenz.edu.co

\section{Álvaro Giovanni González- Herrera}

Psicólogo de la Fundación Universitaria Konrad Lorenz, Colombia. Especialista en Gerencia en Seguridad y Salud en el Trabajo, Especialista en Medición y Evaluación en Ciencias Sociales y Magíster en Psicología. giovanni.gonzalez@konradlorenz@edu.co

\section{Carlos-María Alcover}

Catedrático de Psicología de los Grupos y de las Organizaciones en la Universidad Rey Juan Carlos, España. Licenciado y Doctor en Psicología por la Universidad Complutense de Madrid. carlosmaria.alcover@urjc.es

\section{Sigmar Malvezzi}

Profesor "Libre Docente" de la Universidad de São Paulo, Brasil; doctor en Comportamiento Organizacional por la

Universidad de Lancaster (UK). sigmar@usp.br

\section{Juan Javier Vesga R.}

Decano de la Facultad de Psicología en la Universidad El Bosque. Doctor y magíster en Psicología de la Universidad del Valle, Colombia. juanjaviervesga@gmail.com

Rafael Chiuzi

Profesor asistente, teaching stream, en la Universidad de

Toronto Mississauga, Canadá. Psicólogo organizacional experto en estrategias para aprovechar el capital humano. rafael.chiuzi@utoronto.ca

\section{Roberto O. Díaz-Juarbe}

Catedrático auxiliar del Departamento de Ciencias Sociales y Justicia Criminal en la Universidad de Puerto Rico en Carolina. Doctor en Psicología Industrial Organizacional de la Universidad de Puerto Rico.roberto.diaz2@upr.edu

\section{Sônia Maria Guedes Gondim}

Profesora titular del Programa de Postgrado del Instituto de Psicología de la Universidade Federal da Bahia,

Brasil. Doctora en Psicología de la Universidade Federal do Rio de Janeiro. sggondim@gmail.com

\section{Mino Correia Rios}

Profesor en la Universidad Estatal de Bahía (UNEB) y en el Centro Universitario Jorge Amado (UniJorge). Magíster en Psicología Social y del Trabajo y Doctor en Psicología en la UFBA. mino.rios@gmail.com

\section{Mónica García-Rubiano}

Docente e investigadora en la Universidad Católica de Colombia. Doctora por la Universidad de Almería (España). Coordinadora de la especialización en psicología de las organizaciones en la Universidad Católica de Colombia.mgarcia@ucatolica.edu.co 


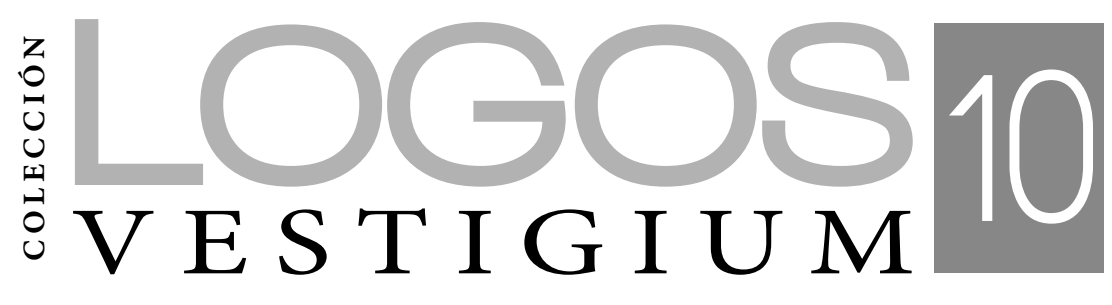

\author{
La vigencia del \\ contrato psicológico: \\ Aproximaciones teóricas y empíricas \\ desde las Américas
}

Carlos-María Alcover Editor 
Vesga Rodríguez, Juan Javier

La vigencia del contrato psicológico: Aproximaciones teóricas y empíricas desde las Américas / Juan Javier Vesga R. y otros once ; Carlos-María Alcover (editor) .-Bogotá: Universidad Católica de Colombia, 2020

252 páginas; 17 x 24 cm.- (Colección Logos Vestigium; no. 10)

ISBN: 978-958-5133-60-0 (impreso)

978-958-5133-61-7 (digital)

I. Tìtulo II. Chiuzi, Rafael III. Díaz-Juarbe, Roberto O. IV. Guedes Gondim, Sônia Maria V. Correia Ríos, Mino VI. García Rubiano, Mónica VII. Forero Aponte, Carlos VIII Martínez-Mejía, Emmanuel IX. Ascencio Cabrera, Erika Mariana X. Aponte-Restrepo, Estefanía XI. González-Herrera, Álvaro Giovanni XII. Malvezzi, Sigmar XIII. Alcover, Carlos-María (editor)

1. Psicología industrial 2. Contrato psicológico

Dewey 158.7 ed 21

\section{Proceso de ARbitraje}

Primer concepto de evaluación:

23 de octubre de 2019

Segundo concepto de evaluación:

25 de noviembre de 2019

(C) Universidad Católica de Colombia

(C) Carlos-María Alcover

(C) Juan Javier Vesga R.

(C) Rafael Chiuzi

(C) Roberto O. Díaz-Juarbe

(c) Sônia Maria Guedes Gondim

(C) Mino Correia Rios

(C) Mónica García-Rubiano

(C) Carlos Forero-Aponte

(C) Emmanuel Martínez-Mejía

(C) Erika Mariana Ascencio Cabrera

(C) Roberto O. Díaz-Juarbe

(C) Estefanía Aponte-Restrepo

(C) Álvaro Giovanni González-Herrera

Primera edición, Bogotá, D.C.

Diciembre de 2020

Dirección Editorial

Stella Valbuena García

CoOrdinación EdiTorial

María Paula Godoy Casasbuenas

Corrección DE ESTILO

Felipe Chavarro (español)

Myriam Rodríguez (inglés)

Diseño DE COLECCIÓN

Juanita Isaza

Diagramación

Andrés Mauricio Enciso B.

Las pruebas citadas en este libro han sido obtenidas de publicaciones electrónicas, tesis de grado y web relacionados. No son ni pretenden ser autoría de los autores que escribieron la presente obra.

\section{Cómo CITAR EN APA}

Impreso

Alcover, C. M. (Ed.). (2020). La vigencia del contrato

psicológico: aproximaciones teóricas y empíricas desde las

Américas. Editorial Universidad Católica de Colombia.

Digital

Alcover, C. M. (Ed.). (2020). La vigencia del contrato

psicológico: aproximaciones teóricas y empíricas desde las Américas. Editorial Universidad Católica de Colombia.

https://doi.org/10.14718/9789585133617.2020

FACUltad DE PSICOLOGÍA

Avenida Caracas \# 46-22

Bogotá, D. C.

psicologia@ucatolica.edu.co

\section{EDITORIAL}

Universidad Católica de Colombia

Av. Caracas 46 - 72 piso 5

Bogotá, D. C.

editorial@ucatolica.edu.co

Todos los derechos reservados. Esta publicación no puede ser reproducida ni total ni parcialmente o transmitida por un sistema de recuperación de información, en ninguna forma ni por ningún medio, sin el permiso previo del editor.

Hecho el depósito legal

(c) Derechos reservados

Licencia Creative Commons Atribución-CompartirIgual 4.0

Internacional (CC BY-SA 4.0)

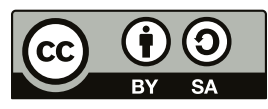


Prólogo

Los contratos psicológicos, sus desafíos y recursos.............................. 9

Sigmar Malvezzi

INTRODUCCIÓN

17

Carlos-María Alcover

PRIMERA PARTE

APROXIMACIONES TEÓRICAS SOBRE EL CONTRATO PSICOLÓGICO

Capítulo 1

Evolución y usos del concepto "contrato psicológico"

Juan Javier Vesga $R$.

CAPÍTUlO 2

A psychosocial approach to psychological contracts:

theory and application for modern organizations

Rafael Chiuzi

CAPÍTULO 3

Una aproximación psicosocial al estudio del contrato psicológico

Roberto O. Díaz-Juarbe, Juan Javier Vesga R.

Capítulo 4

Contratos psicológicos y moralidad: en busca de relaciones

de trabajo mas justas

Sônia Maria Guedes Gondim, Mino Correia Rios

SEGUNDA PARTE

APROXIMACIONES EMPÍRICAS SOBRE EL CONTRATO PSICOLÓGICO

CApítulo 5

Relación entre calidad de vida laboral, contrato psicológico

y cambio organizacional en trabajadores formales colombianos..... 117

Mónica García-Rubiano, Carlos Forero-Aponte 


\section{Capítulo 6}

Aproximación a la dinámica del contenido del contrato

psicológico en méxico: estudio comparativo entre trabajadores

de organizaciones de la iniciativa privada e instituciones

de gobierno

Emmanuel Martínez-Mejía, Erika Mariana Ascencio Cabrera,

Carlos-María Alcover

Capítulo 7

Configuración del contrato psicológico en profesores

universitarios en condición de multiempleo.

Juan Javier Vesga R., Roberto O. Díaz-Juarbe

CApítulo 8

Caracterización del contenido del contrato psicológico

en un grupo de voluntarios de una organización sin ánimo

de lucro en colombia

Estefanía Aponte-Restrepo, Álvaro Giovanni González-Herrera

\section{TERCERA PARTE}

BALANCE Y PERSPECTIVAS DE FUTURO

Capítulo 9

El largo pasado y la corta historia del contrato psicológico

y las relaciones empleado-organización

Carlos-María Alcover 


\section{GRUPO: EUROPSIS}

\section{LÍNEA DE INVESTIGACIÓN}

Psicología organizacional

\section{PROYECTO:}

Configuración del contrato psicológico en trabajadores en condición de multiempleo: el caso de profesores universitarios 



\section{Resumen}

Los continuos cambios que caracterizan al mundo del trabajo y las relaciones laborales en la actualidad modifican de diversas formas las percepciones, las expectativas y las creencias de los trabajadores y los empleadores acerca del contenido y el cumplimiento de sus relaciones de intercambio. Estas percepciones, expectativas y creencias configuran los contratos psicológicos, los cuales definen el marco de las interacciones entre los individuos y los agentes organizacionales e influyen en sus actitudes, comportamientos y decisiones. Por todo ello, el contrato psicológico constituye un elemento fundamental para la comprensión de los procesos psicosociales implicados en las relaciones laborales.

El libro que se presenta a continuación tiene como objetivo ofrecer una panorámica de la diversidad que caracteriza la reflexión conceptual y la investigación sobre el contrato psicológico realizadas desde varios países de las Américas. Investigadores e investigadoras de Colombia, Puerto Rico, México, Brasil, Canadá y España presentan un conjunto de trabajos teóricos y empíricos que tratan de profundizar en la comprensión de las relaciones empleado-organización en los múltiples contextos de trabajo de los respectivos países. En suma, este libro ofrece por primera vez una panorámica amplia, aunque no exhaustiva, de la investigación sobre el contrato psicológico en una selección de países americanos de habla española, inglesa y portuguesa del sur, centro y norte del continente, y representa una valiosa aportación a la investigación en psicología de las organizaciones y del trabajo en estos contextos.

Palabras clave: contrato psicológico, relaciones laborales, expectativas, creencias, relaciones de intercambio, procesos psicosociales, trabajo. 


\section{Abstract}

The continuous changes that characterize the world of work and labor relations today change in various ways the perceptions, expectations and beliefs of workers and employers regarding the content and fulfillment of their commercial relations. Thus, these perceptions, expectations and beliefs configure psychological contracts which define the framework of the interactions between individuals and organizational agents and influence their attitudes, behaviors and decisions as well. That's why the psychological contract constitutes a fundamental element for understanding the psychosocial processes involved in labor relations.

This book aims to offer an overview of the diversity that characterizes the conceptual reflection and research on the psychological contract carried out from various countries in the Americas. Researchers from Colombia, Puerto Rico, Mexico, Brazil, Canada and Spain present a set of theoretical and empirical works that seek to deepen the understanding of employee-organization relations in the multiple labor contexts of their countries.

Summarizing, this book offers for the first time a broad, though not exhaustive, overview of psychological contract research in a selection of Spanish, English, and Portuguese-speaking American countries in the south, center, and north of the continent, also represents a valuable contribution to research in organizational and work psychology in those contexts.

Keywords: psychological contract, labor relations, expectations, beliefs, exchange relationships, psychosocial processes, work. 


\section{PRÓLOGO \\ LOS CONTRATOS PSICOLÓGICOS, SUS DESAFIOS Y RECURSOS}

Sigmar Malvezzi, Ph. D.*

Universidade de São Paulo

La interacción interpersonal es una actividad rutinaria y estructurante de la existencia humana, individual y colectiva, que actúa como acción mediadora. Por existencia humana se entiende la trayectoria de vida construida a través de complejos intercambios entre individuos y grupos en el emprendimiento de retos que utilizan los recursos físicos del ambiente; la interacción es una herramienta visible desde los primeros momentos de la vida humana. Interactuando entre sí, los individuos logran complementariedad para sobrevivir y realizarse administrando la adaptación individual y colectiva que hace viable las trayectorias. La trama de intercambios que produce la complementariedad para la provisión de insumos materiales, subjetivos y culturales para la adaptación necesaria del ser biológico, se construye a través de la mediación de la interacción entre los individuos. Actuando como mediadora, la interacción es un recurso crucial de la cooperación.

La cooperación es una forma de relación que articula a los individuos para compartir sus recursos y acciones, poniéndolos al servicio de las necesidades, aspiraciones y proyectos de otros. La cooperación es una propiedad de la relación que pauta el intercambio de insumos entre el yo y el otro para satisfacer la complementariedad en la construcción de sus existencias en sociedad. La relación cooperativa direcciona la interacción para servir a la adaptación. El análisis de la cooperación desvela estructuras y mecanismos subjetivos que la subyacen y los conflictos y paradojas que la pueden dificultar. Su comprensión, sea a través de una simple relación diádica o a través de la compleja trama de intercambios entre distintos individuos y grupos, atrajo la curiosidad humana desde los tiempos más remotos. Buscando esa comprensión, la sociedad

\footnotetext{
${ }^{*}$ https://orcid.org/0000-0002-4103-6654
} 
aprendió a identificar y administrar esas estructuras y mecanismos, logrando la cooperación. La cultura, la religión, las leyes y los contratos psicológicos despuntan como algunos de esos mecanismos y estructuras que pueblan la interacción interpersonal.

La cultura, la religión y las leyes ofrecen patrones de interacción para que los individuos construyan puentes entre sí, creando mecanismos de intersubjetividad. La intersubjetividad articula sentidos, valores y normas para regular diferencias que pueden ser obstáculos potenciales de la interacción. Las tablas de piedra que Moisés recibió de Yahvé son una ilustración de tales patrones. Esa articulación entre cultura, leyes y religión es un recurso que crea trayectorias para las demandas de adaptación al mundo físico y a los efectos del propio ajuste de la subjetividad individual. Los patrones intersubjetivos de adaptación son transmitidos de una generación a otra, como lo fueron las tablas de Moisés, a través de la socialización y de las artes, que fueron un mecanismo poderoso de enseñanza de modos de interacción y de vida, antes de la sistematización del conocimiento científico. La psicología, la antropología y la sociología dedicaron un espacio significativo a la explicación de las relaciones interpersonales.

Las ciencias dieron un carácter universal a la evaluación y diferenciación entre conocimiento verdadero y falso, entre creencias confiables y no confiables, para explicar y fundamentar la acción sobre la intersubjetividad. El intercambio entre la ciencia y otras distintas fuentes de comprensión de la relación interpersonal estructuró el desarrollo del conocimiento que hoy la sociedad tiene acerca de sí misma, de los comportamientos de los individuos que la constituyen y de los mecanismos que los producen. Buscando profundizar en la comprensión de la relación interpersonal, la sociedad aprendió a identificar los mecanismos y estructuras que tejen la trama de puentes entre los individuos y las condiciones que los sostienen, como la libertad, la inteligencia, los sentimientos, las identidades, la vida comunitaria y los emprendimientos. Esos mecanismos y condiciones exponen la compleja instrumentalización subjetiva ofrecida por las estructuras que subyacen y construyen la relación yo-otro. Ese aprendizaje fue registrado y puesto a disposición en los poemas, en la literatura novelesca y en las películas.

Las diversas formas de representación de la sociedad y de su construcción revelan el conocimiento que hoy permite emprendimientos sobre la mediación de la trama de interacciones entre individuos y grupos. El arte es una reproducción imaginaria, pero competente para reproducir la trama de mecanismos y estructuras subjetivas que promueven y sostienen las relaciones interpersonales y su acción mediadora en la construcción de la existencia individual y en sociedad. Las artes, particularmente las literarias y las escénicas, reconstruyen, directa o indirectamente, la riqueza de recursos y soluciones que los individuos inventan para su adaptación al entorno 
produciendo las trayectorias que revelan su existencia. Basta analizar una película como Una aventura extraordinaria (La Vida de Pi) (Ang Lee, 2012), o el libro del mismo nombre (Yann Martel, 2013, Editorial Destino) para reconocer los mecanismos y estructuras que viabilizan la interacción interpersonal descrita en esas dos obras que son imaginarias, pero realistas de la relación entre un chico y un tigre, durante un periodo de doscientos días en un barco perdido en el Océano Pacífico. Como las artes, las ciencias igualmente enriquecen la comprensión de la trama de interacciones entre el yo y el otro.

Este libro es una sistematización de los contenidos creados en el campo del conocimiento científico para explicar los mecanismos y la formación de los contratos psicológicos. Su reto es explicitar que los contratos psicológicos son un mecanismo crucial de la construcción de los puentes entre los individuos y los grupos. Tal como las manos y el lenguaje simbólico, los contratos psicológicos son instrumentos de adaptación exclusivos de la condición humana, son mecanismos que construyen y reproducen la intersubjetividad y su carácter flexible para servir a individuos creativos que aprenden continuamente a ajustarse al entorno, construyendo trayectorias compartidas de sus existencias. Los contratos psicológicos pueblan la rutina que instrumentaliza los medios que el yo y el otro crean para compartir sus recursos, y son propios de la condición humana, porque revelan la adaptación entre individuos creativos y libres que buscan complementariedad en relaciones de cooperación recíproca.

La complementariedad a través de la cooperación recíproca es aprendida desde los años de la infancia y llega a ser más compleja con la madurez y la autonomía del individuo. Los contratos psicológicos son compromisos recíprocos de relaciones cooperativas para subsidiar la complementariedad, reconociendo y respetando la autodeterminación que caracteriza al yo y al otro. La comunicación sistematizada de esos compromisos, tal como este libro lo expone, desvela la complejidad de la relación yo-otro, las estructuras subjetivas que la producen, los mecanismos que la sostienen y los problemas que la desafían. Este libro explicita los factores, procesos y problemas implicados en el desarrollo de esos compromisos y los factores que facilitan o dificultan su materialización.

Las relaciones interpersonales, la adaptación y la cooperación, llegaron a ser más complejas en la sociedad actual por fuerza de la velocidad de los eventos, de las incertidumbres, del multiculturalismo y de la creciente intermediación de herramientas-sistemas en las actividades humanas. Hoy es rutina desempeñar e interactuar a través de la mediación de plataformas donde las interacciones son normativizadas y limitadas por procedimientos programados. El estudio de los contratos psicológicos esclarece muchos aspectos que angustian a los individuos en la gestión de sus 
comportamientos adaptativos dentro de esas plataformas. Esa emergente mediación explica por qué, en los últimos cincuenta años, la investigación de los contratos psicológicos creció significativa y exponencialmente dentro del campo de las ciencias sociales. El espacio de la gestión de los negocios como consecuencia de la flexibilización, alta velocidad y virtualización de los eventos, requiere del dominio más consistente de la interacción bajo esas condiciones que integran los protagonistas a pesar de la larga distancia física entre ellos.

Ese desarrollo de la investigación de los contratos psicológicos no fue casual, sino resultante de la demanda de comprensión más profunda y consistente de la interacción dentro de contextos constituidos por desempeños virtuales y programados. La relación empleado-organización se convirtió en un vínculo menos regulado por los individuos y más administrado por la mediación del imaginario, potencializando posibilidades de controversias, conflictos e inestabilidad. El diálogo, que siempre fue herramienta crucial de la interacción, enfrenta en la actualidad limitaciones en la comunicación a través de plataformas. Hoy, la producción económica, por fuerza de las tecnologías de la globalización, intervino en la división de las tareas, que es un factor neurálgico en la relación empleado-organización y, por lo tanto, en los mecanismos de la interacción interpersonal en equipos. La compresión del tiempo y del espacio propiciada por las nuevas tecnologías de la comunicación y de intervenciones distantes cambió los mecanismos de supervisión del trabajo, debilitando el poder de la autoridad gerencial en esa relación. Los patrones de interacción interpersonal evolucionaron, a través de ecuaciones constituidas por relaciones cuerpo a cuerpo, desde la cooperación hacia la cooperación distante, bajo fuerte mediación del imaginario colectivo.

Este cambio en los mecanismos de interacción agitó la estructura jerárquica que fuera, hasta mitad del siglo XX, herramienta efectiva para el control de la relación organización-empleado. La estructura jerárquica perdió fuerza frente a la articulación social en redes, la comunicación veloz y la ambigüedad propia del multiculturalismo. Este contexto requiere mecanismos de gestión más flexibles para supervisar tareas más artesanales e imprevistas. Una nueva gramática social emergió de la facilidad y la velocidad de la comunicación interpersonal, en la cual los contratos psicológicos despuntan con un realce significativo.

Este realce es explicado por el cambio en la actividad gerencial que tuvo que adaptarse a la migración del control operacional sobre las relaciones interpersonales de sus equipos, hacia el autocontrol. Esa migración debilitó la autoridad como herramienta de gestión y fortaleció otras herramientas como el liderazgo, los equipos autodirigidos y los contratos psicológicos como mecanismos de gestión que son compartidos 
y requieren cooperación. Dentro de esa gramática, la acción gerencial tuvo que buscar flexibilidad y espacio para la participación artesanal de los individuos, actuando “just-in-time" en eventos que se mueven con rapidez, con virtualización de muchas actividades y con complejidad de las redes. Los contratos psicológicos, al igual que el liderazgo, ofrecen muchos recursos para la integración de los equipos, el autocontrol y la supervisión de tareas en ambientes donde el trabajador es protagonista y artífice.

Esos cambios fueron institucionalizados a través de la introducción gradual de nuevos formatos de gestión, como las células de manufactura y los equipos autodirigidos, en los cuales la división de tareas y la regulación de la producción son responsabilidades compartidas entre los componentes de los equipos. Estos nuevos formatos presuponen el autocontrol y, por lo tanto, la supervisión más dependiente de mecanismos como los contratos psicológicos que comparten los ajustes a contingencias específicas. Los contratos psicológicos se convirtieron en herramientas de supervisión más visibles con la reinstitucionalización del trabajo en la forma del empleo hacia la forma del trabajo autónomo precario. La gestión del desempeño de tareas en equipos se compartió entre los operarios, condición que pone la intersubjetividad como factor crucial de la acción gerencial por el hecho de ser la materia prima del liderazgo y de los contratos psicológicos. Ambos se convirtieron en factores estratégicos tanto para la obtención de resultados como para el desarrollo de la calidad de vida en el trabajo.

El reconocimiento de ese carácter estratégico del autocontrol demanda comprensión más profunda de los contratos psicológicos como herramienta efectiva para la formación de equipos que funcionan fuera del espacio de alguna estructura jerárquica. ¿Cómo se podría administrar la supervisión de trabajadores físicamente distantes y acoplados al ritmo de herramientas-sistemas? Dentro de ese contexto, la comprensión de las regularidades y de las razones de la confianza de los otros fundamenta más claramente la efectividad de la supervisión gerencial. Los contratos psicológicos despuntan como mecanismos para la gestión capaz de administrar la paradoja del trabajador protagonista y artífice de la adaptación de las tareas y de su propia autoproducción, actuando dentro de redes y plataformas que imponen ritmos y procedimientos que él no puede flexibilizar. Desde la implementación de los modelos de gestión, como las células de manufactura, el trabajador encontró condiciones de trabajo que son manejadas por él, o con su participación. La cooperación con los otros y la interfaz entre su trabajo y las relaciones con el entorno dependen de los vínculos creados a través de los contratos psicológicos. Esta dependencia le impone al trabajador más actuación para ajustar los contratos psicológicos con el propósito de que lo apoyen y capaciten para dar cuenta de situaciones paradójicas, de las incertidumbres y de los cuidados con él mismo. 
Estos cambios en la gestión del trabajo revelan que el protagonismo del trabajador pone en sus manos las actividades de su adaptación personal al entorno y las actividades relacionadas con las demandas por sus tareas y metas de trabajo. Dicho de otra forma, hoy los retos de supervivencia, de realización personal y de efectividad, son administrados concomitantemente con las demandas de producción. Su adaptación llegó a ser una acción más amplia y compleja que le demanda de administrar las tareas y su propia autoproducción. Esa demanda requiere más acciones afirmativas que podrán ser facilitadas con el apoyo de sus contratos psicológicos. Bajo una gramática social que separa el apoyo de instituciones y los patrones culturales a sus desempeños, los contratos psicológicos pueden actuar como fuentes inspiradoras de trayectorias y de sentidos para su adaptación. Ellos implican visión de largo plazo y valoración de la cooperación que, a su vez, implica atención continua a su capacitación y su relegitimación.

La construcción de la existencia individual y en sociedad para realizar retos definidos por el trabajo y retos deseados por el trabajador demanda aprendizaje de la cooperación y de su sostenibilidad a través de vínculos de largo plazo. Los contratos psicológicos son una herramienta necesaria e inevitable en esa difícil articulación. Su efectividad es sensible a la reciprocidad que es factor crucial para la sostenibilidad de la intersubjetividad, observada en las comunidades de práctica. Articular la intersubjetividad es una tarea compleja y mediada por el mecanismo integrador de los contratos psicológicos que crean normas de conducta para el yo y el otro que buscan cooperación entre sí.

A diferencia de las estructuras biológicas, muchas de las estructuras subjetivas implicadas en la creación de los contratos psicológicos no son directamente observables ni susceptibles de experimentación, ampliando el desafío de su comprensión. Esta dificultad fue superada por la investigación científica que desarrolló métodos para observar esas estructuras a través de las inferencias, que son herramientas que funcionan bajo el control de la lógica. Las estructuras subjetivas como los contratos psicológicos y el liderazgo, son articulaciones subjetivas reconocidas a través de inferencias sobre la observación de la relación yo-otro. La observación identifica regularidades que son explicadas por conceptos y teorías que explicitan las cadenas de razones que subyacen a los comportamientos. Este esfuerzo de observación y de interpretación de las regularidades en la relación interpersonal abre los ojos del gestor para el reconocimiento de las estructuras subjetivas, como los valores, creencias, representaciones e identidades, que son los elementos que justifican la consideración de vínculos o compromisos recíprocos, los cuales conforman los contratos psicológicos. 
La investigación de estas estructuras es un gran desafío, no solamente para el gestor sino también para la psicología, que estudia fenómenos que son inferidos, no observables, y que no pueden ser provocados en situaciones experimentales. Es por ese motivo que aún cabe preguntarse si los contratos psicológicos existen y si vale la pena explicar las relaciones interpersonales a través de este concepto. Seguramente, el lector de este libro, al final de su lectura, tendrá comprensión más clara de los desafíos de su propia emancipación.

Una de las señales de los contratos psicológicos es su espontaneidad. Tal aspecto ha sido un desafío para la psicología porque es difícil inducir la espontaneidad en situaciones experimentales, tal como se observa igualmente en la investigación del amor, que es otra situación que implica espontaneidad. Así como los contratos psicológicos, el amor es manifestado a través de la observación de regularidades en las conductas e inferido como una articulación interna de la subjetividad del individuo que logró una dimensión estructural. El amor es un objeto que resiste a la experimentación porque resulta de reacciones espontáneas que no pueden ser provocadas, sino solamente estimuladas. Los contratos psicológicos son regularidades análogas, igualmente originadas a través de situaciones espontáneas. Por causa de esta dificultad, uno de los desafíos de su estudio se relaciona con su categorización, que es compatible con los conceptos de expectativa, compromiso, relación de reciprocidad, obligación-derecho y vínculo. Todas estas categorías permiten explicar las regularidades encontradas en la complementariedad, y aún no hay elementos seguros para diferenciarlas.

El contenido de este libro apoyará a su lector en la sistematización de la búsqueda de la comprensión de los contratos psicológicos. Su análisis le permitirá reconocer sus propias experiencias y observaciones y le comunicará las dudas que los psicólogos tienen y comparten con él. El lector de este libro reconocerá fácilmente los contratos psicológicos como estructuras y mecanismos de la interacción y los desafíos para su comprensión. Su lectura enriquecerá sus herramientas para ampliar la comprensión de los problemas que las personas enfrentan para lograr cooperación, complementariedad y calidad de vida. 



\section{INTRODUCCIÓN}

Carlos-María Alcover*

Universidad Rey Juan Carlos, Madrid

Sesenta años después de que Argyris (1960) y Levinson, Price, Munden, Mandl y Solley (1962) utilizaran el término "contrato psicológico" para referirse a un tipo de contrato no escrito conformado por la suma de expectativas mutuas entre la organización y el empleado (Thomas \& Anderson, 1998), la investigación sobre el constructo continúa plenamente activa y en estado de efervescencia (Coyle-Shapiro, Costa, Doden \& Chang, 2019; Griep \& Cooper, 2019). Esta creciente actividad investigadora ha sido especialmente fructífera a partir de la década de los noventa (Conway \& Briner, 2009) y ha reflejado los significativos cambios producidos desde entonces en los contextos de trabajo, las relaciones laborales y las organizaciones (Bankins, Griep \& Hansen, 2020; Conway \& Pekcan, 2019). A lo largo de estas décadas, los significados del constructo han cambiado y los debates y controversias entre los investigadores lo han convertido en uno de los conceptos de mayor utilidad y con mayor presencia como marco teórico en el análisis de las relaciones entre el individuo y la organización (Coyle-Shapiro, Shore, Taylor \& Tetrick, 2004; Kraak \& Linde, 2019).

Para entender los cambios de perspectiva en relación con los contratos psicológicos durante estos años hay que considerar simultáneamente las transformaciones de los significados de términos como "empleado", "trabajo", "organización", "contrato", "empleo" o "relaciones laborales". El arco de las distancias entre los significados y las realidades a las que hacen referencia puede trazarse con el contraste entre las acepciones utilizadas en estos dos ejemplos separados por sesenta años. En 1960, para Argyris (1960), la principal función del contrato psicológico se encontraba en que si los capataces o supervisores garantizaban y respetaban las normas que caracterizaban la

\footnotetext{
${ }^{*}$ https://orcid.org/0000-0001-9632-9107
} 
cultura informal de los trabajadores (tales como métodos relajados de supervisión, percepción de unos salarios adecuados y garantía de un trabajo estable y seguro) se facilitaba el mantenimiento de una elevada productividad y de un menor número de conflictos laborales y de huelgas (Alcover, 2002). En 2020, Bankins y Formosa (2020) reflexionan acerca de cómo se establecen los contratos psicológicos entre robots sociales (también llamados robots humanoides) y empleados, considerando que las relaciones entre ambos pueden establecerse como compañeros de trabajo (miembros de un mismo equipo) o como una relación empleado-supervisor, donde las funciones de este puede desempeñarlas un robot o un dispositivo de inteligencia artificial. En los próximos años, el estudio de los efectos de la digitalización del trabajo en el empleo y las ocupaciones (Fossen \& Sorgner, 2019), con su correspondiente redefinición de las relaciones empleado-organización y de los contratos psicológicos, constituirá sin duda un área prioritaria de investigación. En definitiva, las relaciones laborales se han transformado, así como las creencias, expectativas, promesas y obligaciones de los múltiples agentes implicados, lo que convierte la formación y desarrollo de los contratos psicológicos en procesos dinámicos y complejos (Alcover, Rico, Turnley \& Bolino, 2017a; Griep, Cooper, Robinson, Rousseau, Hansen, Tomprou et ál., 2019; Rousseau, Hansen \& Tomprou, 2018).

$\mathrm{Al}$ igual que los significados y las realidades laborales se han transformado en las últimas décadas, las propias relaciones entre el empleado y la organización se han convertido en procesos más complejos y volátiles. Así, la consideración tradicional de la organización como un agente único, o representada por los supervisores directos (Petersitzke, 2009), se ha sustituido por el enfoque de la agencia múltiple, o los múltiples focos (Alcover et ál., 2017a), donde se identifican diferentes agentes organizacionales que se encuentran implicados e influyen en la formación y desarrollo de los contratos psicológicos: supervisores, responsables en diferentes niveles jerárquicos, gerentes o miembros de la alta dirección. Todos ellos pueden tomar decisiones e influir de manera diversa en el desarrollo de las carreras de los empleados, y crean ecosistemas profesionales característicos por medio de una amplia variedad de flujos recíprocos de ayuda, obligaciones y recursos (Baruch \& Rousseau, 2019; Rousseau, 2020). Esta multiplicidad de agentes también ha traído consigo la dificultad de establecer un único cumplimiento o una única ruptura o violación del contrato psicológico, ya que algunos agentes organizacionales pueden cumplir las promesas y otros no hacerlo, o hacerlo en unas ocasiones y no en otras, de modo que los cumplimientos e incumplimientos ya no se referirían a estados experimentados como "todo o nada” (Alcover et ál., 2017a, 2017b). Por otra parte, las relaciones laborales actuales también fomentan que los empleados establezcan relaciones triangulares con dos o 
más organizaciones; es decir, están contratados por un empleador, pero realizan su trabajo en otra u otras empresas, como ocurre con los servicios externalizados y la prestación laboral parcial o temporal en múltiples entidades. Estas nuevas condiciones impiden la consideración de un contrato psicológico "único", el tradicional establecido entre el empleado y la organización, y conllevan al establecimiento de un contrato psicológico distribuido (Alcover et ál., 2017b) o contratos psicológicos múltiples, simultáneos y anidados, entre diferentes agentes que pueden pertenecer a su vez a distintas organizaciones (Knapp, Diehl \& Dougan, 2020; Raeder, 2018). También es preciso considerar cómo las condiciones económicas abusivas y los contextos de explotación laboral pueden incidir en los procesos de incumplimiento y violación de los contratos psicológicos y en las respuestas de los empleados a ellos (Braeklan \& Sowa, 2015), experiencias que pueden afectar a los colectivos de trabajadores más vulnerables, como es el caso de las personas con discapacidad (Alcover, Martínez-İ̃nigo \& Zambrano, 2007; Kim \& Choi, 2010) o en sectores ocupacionales caracterizados por el trabajo precario (Alcover, Martínez-Í̃igo \& Rodríguez-Mazo, 2005; Tomprou \& Bankins, 2019). En definitiva, los contextos de trabajo y las organizaciones en la actualidad presentan escenarios laborales y relacionales muy diferentes de los definidos en las últimas décadas del siglo XX, y a los que la investigación y la intervención tratan de analizar, comprender y dar respuesta.

El libro que se presenta a continuación tiene como objetivo ofrecer una panorámica de la diversidad que caracteriza la reflexión conceptual y la investigación sobre el contrato psicológico realizadas desde varios países de las Américas. Investigadores e investigadoras de Colombia, Puerto Rico, México, Brasil, Canadá y España presentan un conjunto de trabajos que tratan de profundizar en las relaciones empleado-organización en los múltiples contextos de trabajo de los respectivos países.

El libro está estructurado en tres partes. La primera de ellas ofrece diferentes análisis conceptuales y teóricos sobre el contrato psicológico. El primer capítulo, titulado Evolución y usos del concepto "contrato psicológico", del profesor Juan Javier Vesga R., de la Universidad Católica de Colombia, ofrece una exhaustiva revisión histórica de la emergencia, evolución y usos en la literatura especializada del concepto. El autor identifica cinco periodos en su evolución: emergencia del concepto, declive de su uso en la literatura especializada, reemergencia y reconceptualización, cuestionamientos al concepto y lecturas alternativas del término.

El segundo capítulo, firmado por el profesor Rafael Chiuzi, de la University of Toronto Mississauga (Canadá) y titulado A psychosocial approach to psychological contracts: Theory and application for modern organizations, tiene como principal 
objetivo presentar con un enfoque práctico los resultados de un estudio de cuatro años que se realizó con gerentes de diferentes organizaciones y sus equipos. Los resultados obtenidos permitieron al autor formular un modelo de contrato psicológico fundamentado en cuatro premisas: la definición y redefinición de sus contenidos, la importancia de la reciprocidad, tanto en su forma homomórfica como heteromórfica, el dinamismo constante de su formulación, y su dependencia, como fenómeno psicosocial, de contingencias tanto intrínsecas como extrínsecas. El autor concluye con unas consideraciones sobre el papel del contrato psicológico en los contextos laborales y organizacionales actuales.

El tercer capítulo lleva por título Una aproximación psicosocial al estudio del contrato psicológico, de los profesores Roberto O. Díaz-Juarbe, de la Universidad de Puerto Rico y Juan Javier Vesga R., de la Universidad Católica de Colombia. Los autores presentan una reflexión teórica sobre el concepto de contrato psicológico desde una perspectiva psicosocial, defendiendo su relevancia en los estudios organizacionales como medio para superar los enfoques predominantemente psicológicos utilizados en la investigación tradicional. Tras analizar la perspectiva psicológica del contrato psicológico, las teorizaciones clásicas sobre las relaciones de trabajo y los cambios experimentados en estas, los autores abordan las perspectivas psicosociales de las relaciones de trabajo y del contrato psicológico para llegar a una formulación del contrato psicológico como configuración subjetiva basada en la teoría de la subjetividad del profesor cubano recientemente fallecido Fernando González Rey (La Habana, 1949 - São Paulo, 2019).

El cuarto capítulo, que cierra la primera parte del libro, firmado por la profesora Sônia Gondim, de la Universidade Federal da Bahia y el profesor Mino Correia Rios, de la Universidade do Estado da Bahia, y titulado Contratos psicológicos y moralidad: en busca de relaciones de trabajo más justas, presenta una visión del contrato psicológico desde la moralidad, incluyendo elementos teóricos y empíricos que faciliten el establecimiento de relaciones de trabajo justas y equitativas a través de una gestión de los contratos psicológicos que tenga en cuenta un compromiso doble soportado en intercambios homomórficos (equivalentes en la forma, con contenidos semejantes) y heteromórficos (no equivalentes en forma).

La segunda parte del libro comprende cuatro capítulos de carácter empírico dedicados al análisis de diferentes procesos laborales y organizacionales relacionados con el contrato psicológico. El capítulo quinto, firmado por la profesora Mónica García Rubiano y el profesor Carlos Forero Aponte de la Universidad Católica de Colombia, y titulado Relación entre calidad de vida laboral, contrato psicológico y cambio 
organizacional en trabajadores formales colombianos, tiene como objetivo identificar la relación entre las condiciones de calidad de vida laboral y la percepción del contrato psicológico con el cambio organizacional en una muestra de trabajadores de empresas de Bogotá.

El sexto capítulo, firmado por el profesor Emmanuel Martínez-Mejía, de la Universidad Nacional Autónoma de México, la consultora Erika Mariana Ascencio Cabrera, de Investigación en Psicología Organizacional S.C., y el profesor Carlos María Alcover, de la Universidad Rey Juan Carlos de Madrid, lleva por título Aproximación a la dinámica del contenido del contrato psicológico en México: estudio comparativo entre trabajadores de organizaciones de la iniciativa privada e instituciones de gobierno. El estudio, en el que participaron 493 trabajadores, tenía como objetivo principal identificar las características del contenido del contrato psicológico y la comparación de su configuración en empleados mexicanos de organizaciones privadas y públicas; y como objetivos específicos, aportar evidencia a la validez y confiabilidad del inventario de contrato psicológico (Rousseau, 2000) en población mexicana, conocer las características del contenido del contrato psicológico en México, y poner a prueba modelos de interdependencia entre los elementos del contenido del contrato psicológico.

El séptimo capítulo, titulado Configuración del contrato psicológico en profesores universitarios en condición de multiempleo, de los profesores Juan Javier Vesga R., de la Universidad Católica de Colombia y Roberto O. Díaz-Juarbe, de la Universidad de Puerto Rico, presenta, a través de un estudio de caso en el que participaron seis profesores y cuatro directivos académicos de ambas universidades ubicadas en Cali, Colombia y San Juan de Puerto Rico, una indagación acerca de la manera como se configura el contrato psicológico en profesores universitarios vinculados laboralmente con varias universidades en relaciones de multiempleo, profundizando en el análisis de las condiciones de trabajo con varias organizaciones y sus relaciones con el contrato psicológico mencionadas al comienzo de esta presentación.

La segunda parte del libro se cierra con el capítulo octavo, titulado Caracterización del contenido del contrato psicológico en un grupo de voluntarios de una organización sin ánimo de lucro en Colombia y escrito por la psicóloga Estefanía Aponte Restrepo y el profesor Álvaro Giovanni González Herrera, de la Fundación Universitaria Konrad Lorenz, donde presentan una investigación dirigida a caracterizar el contenido del contrato psicológico de voluntarios que forman parte de organizaciones sin ánimo de lucro y a analizar sus similitudes y diferencias con el desarrollo y el contenido de los contratos psicológicos que se establecen en relaciones laborales tradicionales basadas en intercambios económicos y sociales. 
La tercera parte, dedicada a presentar un balance y perspectivas de futuro, cierra el libro con el capítulo del profesor Carlos María Alcover, titulado El largo pasado y la corta historia del contrato psicológico y las relaciones empleado-organización. En este capítulo se trata de ofrecer una síntesis y recapitulación del estado actual de la investigación y la práctica sobre este constructo, así como de sus futuras líneas de investigación, y una reflexión sobre las tensiones y paradojas, tanto conceptuales como relativas a los contextos de trabajo en los que se encuentran implicados, articuladas en tres ejes: 1) el enfoque de la agencia múltiple, o múltiples stakeholders; 2) el carácter temporal del contrato psicológico; y 3 ) el papel del contrato psicológico y los contratos idiosincrásicos (i-deals) en las nuevas relaciones laborales. El capítulo finaliza presentando sugerencias y ámbitos de interés para la investigación del contrato psicológico en los próximos años.

En suma, este libro ofrece una panorámica amplia, aunque no exhaustiva, de la investigación teórica y empírica sobre el contrato psicológico en una selección de países americanos de habla española, inglesa y portuguesa del sur, centro y norte del continente. Como editor de esta obra, deseo expresar mi reconocimiento y agradecimiento a quienes la han hecho posible. En primer lugar, a los investigadores y las investigadoras que han participado en ella por su implicación, su comprensión y su paciencia a lo largo del proceso, así como a sus universidades e instituciones por financiar y apoyar los proyectos de investigación que sustentaron sus trabajos. En segundo lugar, al profesor doctor Sigmar Malvezzi, del Instituto de Psicología de la Universidade de São Paulo, por su generosidad al aceptar escribir la estimulante reflexión que sirve de prólogo a este libro. En tercer lugar, a la profesora doctora Idaly Barreto, decana de la Facultad de Psicología, al profesor doctor Julián Camilo Sarmiento, director del Centro de Estudios e Investigaciones en Psicología, y a los y las responsables de la Editorial de la Universidad Católica de Colombia por su compromiso y su decidido apoyo para culminar la publicación de este trabajo colectivo. Por último, quiero agradecer expresamente al profesor doctor Erico Rentería Pérez, director del Grupo de Investigación en Psicología Organizacional y del Trabajo del Instituto de Psicología de la Universidad del Valle, y de la Universidade Federal da Bahia, su triple papel como facilitador de la gestación de este proyecto durante la celebración en octubre de 2017, en Cali, del V Congreso Iberoamericano de Psicología de las Organizaciones y del Trabajo, como curator o intermediario de conocimiento durante su etapa como coordinador de la Red Iberoamericana de Psicología de las Organizaciones y del Trabajo (Ripot) entre 2017 y 2019, y como modelo de ética y compromiso académicos en la etapa final del proceso editorial; su espíritu y su ejemplo, ya que lamentablemente no su firma, están presentes en este libro. Espero y deseo que una segunda edición del libro permita incluir no solo el trabajo del profesor Rentería, sino también los 
trabajos de investigadores e investigadoras de otros países americanos, logrando con ello enriquecer y mantener vivo el debate sobre el constructo y los significados de los contratos psicológicos y sobre las complejas relaciones empleado-organización en la tercera década del siglo XXI, que ha comenzado profundamente marcada por las consecuencias sociolaborales y económicas - además de los obvios efectos sobre la salud y la vida de las personas- provocadas por la pandemia del Covid-19.

\section{Referencias}

Alcover, C. M. (2002). El contrato psicológico. El componente implícito de las relaciones laborales. Ediciones Aljibe.

Alcover, C. M., Martínez-Íñigo, D. \& Rodríguez-Mazo, F. (2005). “¿Cuánto tiempo trabajaremos aquí?” Antigüedad en la organización y características de los contratos psicológicos en empleados de call/contact centers. Revista de Psicología Social, 20, 73-91.

Alcover, C. M., Martínez-Î́nigo, D. \& Zambrano, Z. (2007). Efectos de las oportunidades de incorporación al mercado laboral sobre el desarrollo del contrato psicológico y las actitudes hacia el trabajo: el caso de trabajadores con discapacidad en el sector de call/ contact centers. Psicologia, 21, 151-176.

Alcover, C. M., Rico, R., Turnley, W. H. \& Bolino, M. C. (2017a). Understanding the changing nature of psychological contracts in 21st century organizations: A multiple-foci exchange relationships approach and proposed framework. Organizational Psychology Review, 7, 4-35.

Alcover, C. M., Rico, R., Turnley, W. H. \& Bolino, M. C. (2017b). Multi-dependence in the formation and development of the distributed psychological contract, European Journal of Work and Organizational Psychology, 26, 16-29.

Argyris, C. (1960). Understanding organizational behavior. Tavistock.

Bankins, S. \& Formosa, P. (2020). When AI meets PC: exploring the implications of workplace social robots and a human-robot psychological contract. European Journal of Work and Organizational Psychology, 2, 215-229.

Bankins, S., Griep, Y. \& Hansen, S. D. (2020). Charting directions for a new research era: addressing gaps and advancing scholarship in the study of psychological contracts, European Journal of Work and Organizational Psychology, 29, 159-163.

Braeklan, K. F. \& Sowa, V. T. (2015). Exploitation by economic necessity: using the marxist conceptualization of exploitation to investigate the impact of workplace violations. Journal of Workplace Rights, 5, 1-10.

Conway, N. \& Briner, R. B. (2009). Fifty years of psychological contract research: What do we know and what are the main challenges. En: G. P. Hodgkinson \& J. K. Ford (eds.). International review of industrial and organizational psychology (pp. 71-131). Wiley-Blackwell. 
Conway, N. \& Pekcan, C. (2019). Psychological contract research: older, but is it wiser? En: Y. Griep \& C. Cooper (eds.). Handbook of Research on the Psychological Contract at Work (pp. 10-34). Edward Elgar.

Coyle-Shapiro, J. A.-M., Costa, S. P., Doden, W. \& Chang, C. (2019). Psychological contracts: past, present, and future. Annual Review of Organizational Psychology and Organizational Behavior, 6, 1-25.

Coyle-Shapiro, J. A.-M., Shore, L. M., Taylor, M. S. \& Tetrick, L. (eds). (2004). The Employment Relationship: Examining Psychological and Contextual Perspectives. Oxford University Press.

Fossen, F. M. \& Sorgner, A. (2019). Digitalization of work and entry into entrepreneurship. Journal of Business Research. https://doi.org/10.1016/j.jbusres.2019.09.019

Griep, Y. \& Cooper, C. (2019). Introduction. En Y. Griep \& C. Cooper (eds.). Handbook of Research on the Psychological Contract at Work (pp. 1-8). Edward Elgar.

Griep, Y., Cooper, C., Robinson, S., Rousseau, D. R., Hansen, S. D., Tomprou, M. et ál. (2019). Psychological contracts: back to the future. En Y. Griep \& C. Cooper (eds.). Handbook of Research on the Psychological Contract at Work (pp. 397-414). Edward Elgar.

Kim, M. S. \& Choi, J. N. (2010). Layoff victim's employment relationship with a new employer in Korea: effects of unmet tenure expectations on trust and psychological contract. The International Journal of Human Resource Management, 21, 781-798.

Knapp, J. R., Diehl, M.-J. \& Dougan, W. (2020). Towards a social-cognitive theory of multiple psychological contracts. European Journal of Work and Organizational Psychology, 29, 200-214.

Kraak, J. M. \& Linde, B. J. (2019). The usefulness of the psychological contract in the 21st century. En Y. Griep \& C. Cooper (eds.), Handbook of Research on the Psychological Contract at Work (pp. 101-121). Edward Elgar.

Levinson, H., Price, C. R., Munden, K. J., Mandl, H. \& Solley, C. M. (1962). Men, Management, and Mental Health. Cambridge, MA: Harvard University Press.

Petersitzke M. (2009). Supervisor Psychological Contract Management. Gabler.

Raeder, S. (2018). Psychological Contracts of Multiple Jobholders: A Multilevel Analysis. Sage Open, 8, 1-18.

Rousseau, D. M. (2000) Psychological Contract Inventory Technical Report. Pittsburgh: Carnegie Mellon University. http://www.andrew.cmu.edu/user/rousseau/0_reports/reports. html

Rousseau, D. M. (2020). Becoming an Organizational Scholar. Annual Review of Organizational Psychology and Organizational Behavior, 7, 1-23.

Rousseau, D. M., Hansen, S. D. \& Tomprou, M. (2018). A dynamic phase model of psychological contract processes. Journal of Organizational Behavior, 38, 1081-1098. 
Thomas, H. D. C. \& Anderson, N. (1998). Changes in newcomers' psychological contracts during organization socialization: A study of recruits entering the British Army. Journal of Organizational Behavior, 19, 745-767.

Tomprou, M. \& Bankins, S. (2019). Managing the aftermath of psychological contract violation: employee-organizational interplay, calling, and socio-cognitive coping in vulnerable work populations. En Y. Griep \& C. Cooper (eds.). Handbook of Research on the Psychological Contract at Work (pp. 206-222). Edward Elgar. 


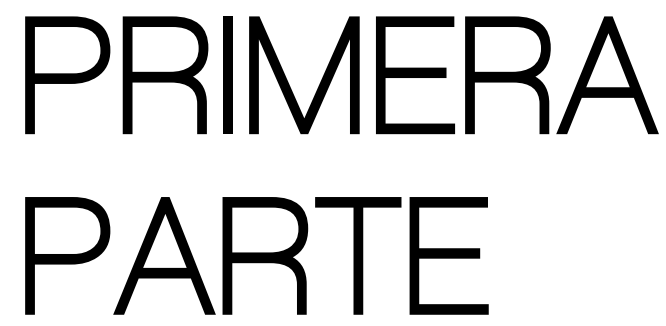

APROXIMACIONES TEÓRICAS

SOBRE EL CONTRATO PSICOLÓGICO 



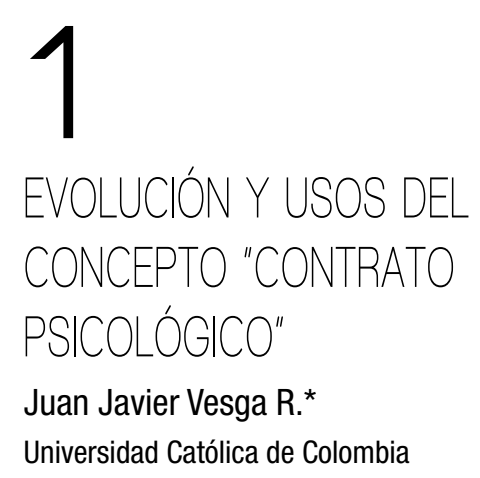

\section{Introducción}

Este capítulo presenta una visión histórica de la emergencia, evolución y usos en la literatura especializada del concepto "contrato psicológico", como una ampliación y profundización del trabajo previo realizado por Vesga (2014).

Los conceptos surgen en un momento histórico determinado, y su uso permanece, en algunos casos, inalterable a través del tiempo, aunque las realidades de las que el concepto intenta dar cuenta se hayan transformado. En otros casos, los conceptos evolucionan a la par que lo hacen las condiciones teóricas o contextuales que llevan a que en la literatura se presenten nuevos usos teóricos para un concepto determinado. Sin embargo, es posible ver que hay una versión oficial y documentada en la literatura, a veces de forma lineal, pero no discutida en términos de los hitos y condiciones de las épocas en las que un concepto sufre transformaciones útiles y necesarias para mantener su vigencia.

Tomando como referente de análisis el concepto de contrato psicológico, se propone un uso contextualizado y crítico de los conceptos que permiten la lectura de fenómenos psicosociales en las relaciones y condiciones de las épocas y momentos históricos clave asociados a cada concepto. Se espera que el uso de un concepto sea un llamado que parta de su vigencia y del reconocimiento de los intereses implícitos. De esta forma, el aporte que busca hacerse es la conceptualización, la mirada histórica del concepto en términos de su evolución en función de hitos, hechos sociales y teorías disponibles, para situarle como relevante en un campo específico del conocimiento. La actualización en la vigencia de los conceptos; más que una reconceptualización,

* https://orcid.org/0000-0003-2382-5104 
es la revisión de un marco de referencia para la lectura y ubicación de las diversas posturas sobre el fenómeno visto desde el concepto.

En cuanto al contrato psicológico se refiere, el interés despertado en este concepto a partir de los años noventa del siglo pasado por los estudiosos e investigadores del tema se debe en gran parte a que este se ha constituido en un elemento teórico importante para entender las complejas relaciones de trabajo en la actualidad, leídas o vistas a través de conceptos específicos que son fenómenos resultantes de las relaciones en sus contextos y condiciones. El concepto como tal, en este caso el contrato psicológico, es la referencia o "disculpa" para leer las relaciones de trabajo y sus implicaciones para las personas inmersas en ellas.

Desde que fuera propuesto por primera vez en 1960, el concepto ha presentado variaciones y matices tanto en su definición como en su concepción y uso en la literatura especializada sobre el tema. En tal sentido, se presenta aquí un análisis de las trasformaciones en las conceptualizaciones que este ha tenido a lo largo de su historia.

Para este propósito, se realizó inicialmente una selección de los principales referentes teóricos del concepto citados o discutidos sobre el tema y considerados claves en la literatura especializada por la comunidad científica. Se destacan autores como Argyris (1960), Levinson, Price, Munden, Mandl y Solley (1962), Schein (1994), Rousseau (1989; 1995), y las discusiones y críticas a las definiciones del concepto propuestas por Arnold (1996), Guest (1998), Conway y Briner (2005) y Cullinane y Dundon (2006), así como propuestas alternativas para la comprensión del contrato psicológico como las de Guest (2004) y de Malvezzi (2011). Posteriormente, se hizo un análisis de las ideas propuestas, "procurando destacar su sentido y caracteres fundamentales" (López, 2002, p. 172) respecto al concepto de contrato psicológico y su relación con el contexto teórico e histórico, que le proveen elementos intertextuales en la construcción de su conceptualización desde diversas perspectivas y concepciones subyacentes.

Como resultado de este análisis, se logró identificar variaciones a lo largo de su historia, tanto en el interés mostrado por investigadores y teóricos por el uso y estudio del concepto evidenciado en las distintas publicaciones, como en las concepciones de los autores sobre el mismo; así como las teorías y conceptos subsidiarios de sus definiciones y conceptualizaciones, las cuales se organizan y presentan en los siguientes tres apartados.

\section{Primer periodo: la emergencia del concepto}

El término contrato psicológico es propuesto por primera vez en 1960 por Chris Argyris en su libro Understanding organizational behavior. En él, Argyris se refiere al 
contrato psicológico como concepto y manifiesta que "es creado con el fin de ayudar a organizar y explicar ciertos fenómenos" (Argyris, 1960, p. 96), específicamente lo que denominó el "liderazgo pasivo" ejercido por los supervisores y sus efectos sobre el comportamiento y desempeño de los empleados en el trabajo. Este hecho significa un estilo de liderazgo comprensivo, una forma de dirigir que implique la asignación de tareas justa y equitativamente entre los empleados, un jefe con buenas relaciones interpersonales, que permite que los empleados puedan trabajar solos tanto como sea posible (Argyris, 1960).

Argyris encontró, en la investigación que es fuente de su libro, características de las relaciones supervisor-empleado en las cuales predominaban factores como los siguientes: confianza de los jefes en sus subalternos, salarios adecuados y respeto de los jefes por las propias prácticas de la cultura informal de los trabajadores, hechos por los cuales estos a su vez se comprometerían a realizar altos niveles de producción y a mantener un bajo nivel de quejas (Argyris, 1960). A tal relación de confianza y acuerdos en la que existe un intercambio de beneficios mutuos, el autor la denominó psychological work contract o contrato psicológico de trabajo. La propuesta de denominarlo "de trabajo" es clave, pues define el trabajo como referente para la delimitación del concepto y evita que se presente en abstracto.

Para Argyris, el contrato psicológico se presenta como una variable mediadora entre el ejercicio del liderazgo de los jefes y la conducta de los trabajadores; al respecto, afirma que los jefes no serían vistos por los empleados como causa de presión si existiera entre ellos un contrato psicológico percibido en el marco de la relación (Argyris, 1960).

Para este autor, este contrato psicológico hace referencia a un conjunto de acuerdos pactados tácitamente entre cada uno de los empleados de un grupo o área determinada de una empresa y su jefe inmediato. Mediante tales acuerdos, cada una de las partes está dispuesta a dar algo en beneficio de la relación de trabajo construida, recibiendo por ello beneficios de manera recíproca en el orden de lo relacional. La denominación que este autor da al fenómeno obedece, por un lado, al carácter contractual de la relación, es decir, los acuerdos hechos entre las partes, y por otro, asume que la condición tácita de tales acuerdos implica su condición de psicológico; de ahí la expresión "contrato psicológico de trabajo".

¿Cuál es el contexto en el que surge este concepto? La década de los sesenta, en la que aparece, es una época de transformaciones en el pensamiento sobre las relaciones de trabajo, especialmente las relaciones jefe-subordinados, ya que en dicha década ocurrieron desarrollos clave en la literatura sobre el liderazgo. De acuerdo con Salas, Priest, Stagl y Burke (2007), en las décadas de los cincuenta y sesenta prevalecía una 
mirada humanística de las organizaciones, ya que según dichos autores, estas son creadas para dar respuesta a las necesidades humanas. "Esta nueva línea de pensamiento cambió la naturaleza de la relación entre empleadores y empleados desde la dependencia a la codependencia" (Salas et ál., 2007, p. 417). Tal época está marcada por una forma particular de estabilización en el contexto de la reconstrucción de la posguerra, motivo por el cual el foco en las personas es central en sus relaciones con las organizaciones de trabajo.

En 1960 se publica también el libro de Douglas McGregor, The human side of enterprise, en la cual se presentan las que el autor denominó teorías X y Y para la comprensión de las relaciones jefe-empleados. Esta obra hace un aporte a la diferenciación, en términos del liderazgo, sobre las concepciones implícitas que tienen los dirigentes acerca del trabajador y su relación con el trabajo y las actividades en la organización. Su propuesta se fundamenta en una crítica a las ideas tradicionales sobre la naturaleza humana - por ejemplo, "la pereza natural del hombre es algo serio" (Taylor, 2003, p. 28) - para ofrecer una visión alternativa orientada más hacia "el lado humano de las organizaciones". Las teorías X y Y implican supuestos sobre la naturaleza humana que tienen los jefes respecto de los trabajadores y que los llevan a relacionarse con ellos en función de tales supuestos, ya que para McGregor (1994) "en la base de toda decisión o acción gerencial existen supuestos sobre la naturaleza y la conducta humanas” (p. 33).

La teoría Y tiene una mirada cercana a la noción de contrato psicológico propuesta por Argyris. En esta perspectiva, McGregor (1994) afirma:

\begin{abstract}
Al considerar el medio psicológico de las personas que trabajan, lo primero que se nos viene a la mente es la relación entre superior y subordinado [...]. Una característica fundamental de esta relación es la interdependencia de las partes. Como en una relación de dependencia mutua cada parte afecta en alguna medida la capacidad de la otra para lograr sus fines o satisfacer sus necesidades, es probable que surjan dificultades de consideración a menos que ambas partes esperen resultados positivos de dicha relación. (p. 130)
\end{abstract}

Esta perspectiva de interdependencia entre las partes que constituyen una relación jefe-empleado es la que subyace a la noción de contrato psicológico propuesta por Argyris, puesto que las partes implicadas se afectan mutuamente y el contrato psicológico termina siendo la resultante de esta interacción como mecanismo para establecer un patrón armonioso en busca de un equilibrio en la interacción de la relación. Claramente aquí el enfoque es de corte sistémico-armónico en la concepción de las relaciones de las personas con su trabajo a partir de dimensiones concretas de su relación con los jefes/líderes. 
La aparición de este concepto ocurre en un periodo en el que el mundo occidental se recuperaba de las condiciones dejadas por la Segunda Guerra Mundial, y tal recuperación se centraba en el crecimiento económico. Según Hobsbawm (1998), en la década de los sesenta "la economía mundial crecía, pues, a un ritmo explosivo. Al llegar los años sesenta, era evidente que nunca había existido algo semejante" (p. 264). Dadas estas condiciones de fortalecimiento económico, según se desprende de los argumentos de Hobsbawm (1998), emergieron una serie de acuerdos entre empresas y empleados procurando una mayor armonía en el desarrollo del trabajo, sin preocuparse mucho por los costos de los salarios. $\mathrm{Al}$ respecto, este autor menciona:

Los acuerdos resultaban aceptables para todas las partes. Los empresarios, a quienes apenas les importaba pagar salarios altos en plena expansión y con cuantiosos beneficios, veían con buenos ojos esta posibilidad de prever que les permitía planificar por adelantado. Los trabajadores obtenían salarios y beneficios complementarios que iban subiendo con regularidad, y un estado del bienestar que iba ampliando su cobertura y era cada vez más generoso. (p. 285)

Como lo plantea Vesga (2014), aquel periodo se caracterizó por condiciones económicas y laborales "que demandaban acuerdos entre trabajadores y empleadores como mecanismo para dar respuesta a la creciente ola de desarrollo económico y estabilización de las relaciones de trabajo, condiciones que están en la base de la formulación del contrato psicológico como concepto" (p. 247). En tal sentido, tal contexto y condiciones, en especial sus características de auge económico, se convirtió en una fuente de expectativas para los trabajadores asociadas a estabilidad laboral y capacitación. Era una época en la cual la tendencia proteccionista de los gobiernos configuraba un Estado de bienestar (Boltanski \& Chiapello, 2002), y las relaciones de trabajo se basaban en la seguridad y estabilidad en el empleo; es la época en que "la seguridad forma parte, por lo tanto, de la definición implícita, pero admitida por todos, del contrato de trabajo" (Boltanski \& Chiapello, 2002, p. 138). De la misma manera, las imágenes del mundo del trabajo y la gestión empresarial estaban basadas en lo sólido, lo estable, las relaciones de largo plazo, la carrera laboral ascendente y lineal y la configuración de una "empresa monolítica integrada, con organización y estructuras estables” (Jauregizar, 1998, p. 174)

También en este periodo, "la literatura gerencial prescribía una cultura de negociación entre patronos y sindicatos, permaneciendo el conflicto social en un nivel latente" (Alonso \& Fernández, 2006, p. 129). De acuerdo con los autores citados, las publicaciones en asuntos de gerencia mantenían la idea de que esta debía trabajar por evitar el conflicto entre jefes y empleados, por lo que "el conflicto social dentro 
de la empresa se puede resolver mediante una adecuada política de gestión" (p. 130), razón por la cual la confianza era un aspecto clave de las relaciones de trabajo: "la retórica dominante era la de la lealtad, la confianza entre empleadores y empleados, el reconocimiento de la existencia de un conflicto social y la búsqueda de un acuerdo tácito entre las clases involucradas en el proceso productivo" (p. 130). Este conjunto de ideas fundamentó la conceptualización del contrato psicológico en aquella época en línea con las características sociales y económicas prevalecientes en ese periodo.

Posteriormente, Levinson et ál. (1962) proponen una conceptualización más elaborada, pues definen el concepto como no lo había hecho Argyris dos años antes. Según estos autores, las dinámicas de la relación de trabajo entre trabajadores y sus organizaciones generan exigencias y compromisos entre las partes que demandan reciprocidad, todo lo cual genera expectativas en ambas partes y es lo que constituye el denominado contrato psicológico. En tal sentido, Levinson et ál. (1962) definen este concepto de la siguiente manera:

... una serie de expectativas mutuas de las que las partes de una relación pueden no
ser siquiera vagamente conscientes pero que sin embargo gobiernan su relación del
uno con el otro. Dada esta estructura, fue evidente para nosotros que la reciprocidad
podría ser entendida como el camino a través del cual el contrato es afirmado, alte-
rado o negado en la experiencia diaria de trabajo dentro de la organización. (p. 21)

La definición presentada por estos autores no se deriva de la propuesta antecedente de Argyris dos años atrás, sino que parte de otra hecha cuatro años antes por el psiquiatra Karl Menninger, quien describiera la existencia de un "contrato de psicoterapia" entre terapeuta y paciente en el marco de procesos psicoterapéuticos (Menninger, 1958). A este respecto, Levinson et ál. (1962) sostienen que a partir de las ideas de Menninger acerca de los "aspectos intangibles de las relaciones contractuales" (p. 21), ellos desarrollaron el concepto de contrato psicológico.

En 1965, en su libro Organizational psychology, Edgar Schein afirma que "la noción de un contrato psicológico implica que hay un conjunto de expectativas no escritas operando en todo momento entre cada miembro de una organización y los gerentes y otros miembros de esa organización" (Schein, 1994, p. 22).

A diferencia de Argyris, quien había propuesto el contrato psicológico como acuerdos tácitos entre las partes de una relación de trabajo, tanto Levinson y colaboradores como Schein, proponen el contrato psicológico como un conjunto de expectativas mutuas que existen por parte de los empleados y de la organización. Para Schein, por ejemplo, los trabajadores desarrollan expectativas sobre salarios, beneficios extra y 
estabilidad laboral, y por su parte, las organizaciones generan expectativas acerca de la lealtad, confidencialidad y compromiso por parte de los trabajadores (Schein, 1994). Las propuestas de Levinson et ál. en 1962 y de Schein en 1965, surgen en un contexto que estaba definido por un contrato social de acuerdos por el progreso, la estabilidad y el desarrollo en las relaciones de trabajo. En aquella época la seguridad formaba parte de la definición implícita, pero admitida socialmente, del contrato de trabajo, y el Estado de bienestar, como se mencionó antes, era considerado como un elemento clave en la dinámica de los negocios (Vesga, 2014). Las organizaciones despedían solo de manera excepcional y se ofrecían posibilidades de emprender carreras de por vida; por su parte, el Estado brindaba seguridades contra el desempleo en caso de que las empresas llegasen a cerrar (Boltanski \& Chiapello, 2002), y en este contexto las relaciones de trabajo estaban marcadas por las expectativas en el largo plazo entre las partes (empleados y organizaciones).

Igualmente, las propuestas Levinson et ál. y de Schein incluyen además otra perspectiva de análisis un tanto diferente a la mirada que hace Argyris sobre el concepto. El foco de comprensión de las relaciones de trabajo como trasfondo en el cual se instauran los contratos psicológicos ya no es la relación diádica jefe-empleado, sino que se amplía a una relación empleado-organización, lo cual en cierta medida implica la introducción de otros referentes para entender las relaciones de trabajo en un marco mucho más amplio, específicamente un sistema social, lo que por aquella época se proponía como el enfoque sistémico de las organizaciones. Esta perspectiva hace su aparición en 1966 con la obra de Katz y Kahn, pero la misma "es una aplicación al campo de la teoría organizacional, de la teoría general de sistemas, cuyos conceptos básicos fueron desarrollados por el biólogo Ludwing Von Bertalanffy a comienzos de la década de los años treinta" (Dávila, 2001, p. 230).

La propuesta teórica de Katz y Kahn (1966) ofrece una visión totalizadora de la organización como sistema social a partir de la teoría de sistemas, la cual "está básicamente involucrada con los problemas de relaciones, de estructura y de interdependencia, más que con los permanentes atributos de los objetos" (Katz \& Kahn, 1966, p. 18). En tal sentido, esta propuesta se centra en concebir las organizaciones como sistemas sociales, los cuales "están anclados en las actitudes, percepciones, creencias, motivaciones, hábitos y expectativas de los seres humanos" (p. 33); de esta manera, la relación de los trabajadores con la organización a la que pertenecen tiene en esta perspectiva un fuerte componente psicológico; de ahí que en las propuestas de Levinson et ál. y de Schein, el contrato psicológico puede ser concebido como un dispositivo de implicación de los trabajadores con la organización en el largo plazo. 


\title{
Segundo periodo: el declive del uso del concepto en la literatura especializada
}

Entre las décadas de los años setenta y parte de los ochenta, el concepto tiene una reducción en el uso por parte de teóricos e investigadores, ya que este, como lo afirma Alcover (2002), "parece olvidarse, o al menos estancarse, pues durante otros quince años no lo encontramos apenas citado por otros autores, ni tampoco se reelabora o se profundiza en los términos planteados en los trabajos iniciales" (p. 47), idea que también es compartida por Conway y Briner (2005), quienes manifiestan:

\begin{abstract}
Antes de finales de los ochenta es difícil identificar un cuerpo de trabajo acerca del contrato psicológico, aunque varios autores, a menudo muy independientemente, mencionan la idea. En otras palabras, aunque el concepto había emergido claramente, fue ampliamente ignorado por varias décadas y se mantuvo sin desarrollo hasta años más recientes. (p. 3).
\end{abstract}

Este estancamiento no implica la eliminación total del concepto en la literatura especializada, sino que es muy pocas veces mencionado en las publicaciones, y cuando se usa, se utiliza en el mismo sentido de las primeras definiciones hechas en la década de los sesenta. En la revisión de la literatura hecha por los autores del presente capítulo, se encontraron cuatro publicaciones en este periodo, siendo solo dos de ellas estudios empíricos.

El primero de ellos es un artículo de Kotter (1973), The psychological contract: managing the joining-up process, en el cual este autor presenta sus ideas, producto de sus investigaciones, sobre el papel que juega el contrato psicológico en el gerenciamiento de los procesos de vinculación de empleados nuevos a las organizaciones; específicamente, define el contrato psicológico como "un contrato implícito entre un individuo y su organización que especifica lo que cada quien espera dar y recibir del otro en su relación" (Kotter, 1973, p. 92).

El segundo trabajo empírico fue el realizado por Portwood y Miller (1976), donde los autores publican los resultados de un estudio longitudinal en el que se analizaron las expectativas iniciales de los sujetos en relación con las percepciones posteriores acerca de las condiciones en el trabajo. En este artículo los autores definen el contrato psicológico como "un acuerdo implícito, negociado entre el empleado y la empresa empleadora (por lo general en el momento de la entrada del empleado), y es un reconocimiento de obligaciones mutuas para ser cumplidas por ambas partes en el curso de su asociación" (p. 109). 
La tercera publicación aparece a finales de la década de los setenta por parte de Schein, quien en su libro Career dynamics: matching individual and organizational needs, publicado en 1978, presenta el contrato psicológico en una dirección similar a la propuesta por Kotter cinco años atrás, esto es, como parte del proceso de vinculación de un individuo a la organización, aunque Schein lo inserta además como un elemento importante del desarrollo de la carrera de un empleado al interior de la organización, específicamente en una etapa inicial a la que denomina "aceptación mutua" (Schein, 1982, p. 135).

La cuarta publicación aparece diez años después, en la que Schein menciona nuevamente el contrato psicológico en su texto de 1988, Process consultation volume $i$, its role in organization development, y lo presenta como un componente importante y clave de las relaciones entre consultores y empresarios en el desarrollo de un proceso de consultoría. Al respecto menciona que un contrato de consultoría tiene dos dimensiones, una formal relacionada con el tiempo dedicado a la misma, los servicios prestados y aspectos referidos al pago, $\mathrm{y}$

\footnotetext{
... el "contrato psicológico" informal que incluye expectativas implícitas (y algunas veces explícitas) del cliente con respecto a lo que obtendrá de la relación y a las obligaciones que aceptará, y las expectativas implícitas (y algunas veces explícitas) del consultor en relación con lo que aportará a la relación, las obligaciones que aceptará y lo que espera obtener de ella. (Schein, 1990, pp. 123-124)
}

¿A qué se debe este desinterés por el concepto en la literatura especializada en dicho periodo?

De acuerdo con Hobsbawm (1998) "la historia de los veinte años que siguieron a 1973 es la historia de un mundo que perdió su rumbo y se deslizó hacia la inestabilidad y la crisis" (p. 403), y de acuerdo con Alonso y Fernández (2006), en aquella época "la productividad y la tasa de ganancia tendían a decrecer y los mercados sometidos a una competencia agónica se fragmentaban" (p. 133).

Dadas las condiciones de recesión y dificultades en la productividad de las organizaciones en aquel periodo, los intereses de la literatura gerencial se centraron en las discuciones sobre el cambio para superar las características de rigidez que caracterizaban a las estructura empresariales, ya que se preveían condiciones de incertidumbre en el contexto económico, razón por la cual conceptos como el de contrato psicológico perdieron interés para teóricos e investigadores. Los temas de cooperación y acuerdos perdían vigencia para dar paso a otros como el cambio y la estrategia de mercados. 
En esta época entra en crisis el taylorismo como sistema de gestión y los dirigentes organizacionales reconocen lo pesado de las organizaciones debido a las macroestructuras burocráticas encargadas de líneas jerárquicas de mando y control, por lo que la seguridad de los asalariados fue sustituida por medidas que trataban de "aligerar el control jerárquico y tomar en consideración los 'potenciales' individuales. A raíz de una inversión de política, la autonomía fue, de alguna manera, intercambiada por la seguridad" (Boltanski \& Chiapello, 2002, p. 280 [cursivas en el original]).

Un asunto importante que debe destacarse es el hecho de que, aunque en la literatura especializada sobre un tema no se haga uso o no se discuta algún constructo o concepto en particular en un periodo determinado, esto no significa que el hecho al que el concepto o constructos se refieren desaparezca de la cotidianidad de las personas o en los sistemas sociales. Tal es el caso por ejemplo del tema de los grupos, sobre el cual Levine y Moreland (1990) refieren que se mantienen vigentes y vivos, aunque el tema haya dejado de ser discutido en la psicología social y la categoría "grupo" se haya dejado de lado en las discusiones teóricas por la época en que estos autores hacían su discusión en torno al tema.

En el caso del contrato psicológico, el poco uso del concepto en la literatura especializada sobre el tema en aquel periodo es indicativo de que, aunque como hecho social este haya estado siempre presente en las dinámicas de las relaciones de trabajo, los intereses de investigadores y teóricos se orientaron hacia otros asuntos que se presentaban como apremiantes, dadas las condiciones sociales, políticas y económicas de esas dos décadas. Las condiciones de inestabilidad financiera en los mercados mundiales, recesión económica y serios problemas de productividad y ganancias de las empresas pusieron en crisis las pesadas estructuras empresariales y los sistemas de gestión basados en el taylorismo y el fordismo. Tanto la literatura gerencial como las estrategias y prácticas administrativas de los gerentes se orientaron hacia la búsqueda de soluciones a las difíciles condiciones del momento, estando el tema del cambio fuertemente marcado en los discursos de la época (Alonso \& Fernández, 2006).

En las relaciones de trabajo, las condiciones de seguridad fueron reemplazadas en esos años por una mayor autonomía de los trabajadores en la búsqueda de aligerar el control jerárquico (Boltanski \& Chiapello, 2002), reduciendo el número de niveles de mando como estrategia para adelgazar las pesadas estructuras organizacionales y elaborando programas de capacitación tanto para gerentes como para empleados en el tema del cambio organizacional. La recuperación del control de las empresas era el objetivo principal de los propietarios y gerentes (Boltanski \& Chiapello, 2002), y 
en este contexto, conceptos comprensivos y explicativos de las relaciones de trabajo como el contrato psicológico no tuvieron espacio representativo en la literatura sobre psicología organizacional de la época.

\section{Tercer periodo: reemergencia y reconceptualización}

A finales de los años ochenta el concepto reemerge en la literatura de la psicología organizacional, y es Denise Rousseau quien lo pone nuevamente en escena con su artículo Psychological and implied contracts in organizations, que se publica en 1989 (Vesga, 2014) y a partir de allí comienza un periodo de resurgimiento del uso del concepto en el campo de la psicología organizacional. Rousseau (1989) lo define como "las creencias individuales respecto de los términos y condiciones de un acuerdo de intercambio recíproco entre una persona específica y otra parte" (p. 123). Luego, en 1995, esta autora amplía la reflexión y conceptualización del contrato psicológico al publicar el libro Psychological contracts in organizations: understanding written and unwritten agreements, en el cual define este concepto como "las creencias individuales, inducidas por la organización, respecto de los términos de un acuerdo de intercambio entre los individuos y su organización" (Rousseau, 1995, p. 9).

El asunto de las promesas es un elemento central en la propuesta de Rousseau, ya que para esta autora el aspecto contractual del contrato psicológico es esencialmente promisorio. Sin embargo, para esta autora, las promesas que forman los contratos psicológicos son percepciones: "las promesas, en última instancia, son las percepciones de lo que fue enviado y fue entendido. Las percepciones no son simples interpretaciones pasivas de la realidad: la gente crea sus significados para muchos eventos" (Rousseau, 1995, p. 27). Este hecho sitúa la formación de contratos psicológicos en una dimensión subjetiva individual, dado que para Rousseau el centro de análisis es el individuo y no la interacción entre dos sujetos como es el caso de la propuesta de Argyris, ni entre individuo-organización, como ocurre en las perspectivas de Levinson et ál. y de Schein.

Una diferencia fundamental de la propuesta de Rousseau $(1989,1995)$ en relación con los trabajos anteriormente publicados (Argyris, 1960; Levinson et ál., 1962; Schein, 1965), se centra en que para esta autora el contrato psicológico es un elemento esencialmente cognoscitivo, basado en las percepciones sobre aspectos del trabajo y la organización. Asimismo, para esta autora los contratos psicológicos se basan en promesas más que en expectativas.

Posteriormente a las publicaciones de Rousseau, y en el inicio del siglo XXI, el interés por el concepto se ha incrementado entre investigadores y teóricos, y el número de 
publicaciones sobre este tema ha tenido un crecimiento exponencial (Coyle-Shapiro \& Parzefall, 2010).

¿Por qué tal interés en ese momento por un concepto del cual no se publicó mucho en las dos décadas anteriores?

El periodo comprendido entre finales de los años ochenta y la década de los noventa del siglo pasado, fue una época de profundas transformaciones tecnológicas, sociales y políticas que consolidaron un nuevo orden mundial, transformaciones que postularon nuevos retos para las ciencias sociales en la comprensión de los fenómenos y hechos sociales que estaban ocurriendo en la administración de recursos humanos.

El contexto de la década de los noventa estuvo caracterizado por la emergencia de los procesos de globalización de la economía impulsados por las transformaciones políticas dirigidas a la consolidación del capitalismo como sistema económico - aunque ya con un matiz de capitalismo financiero-y los importantes desarrollos en materia de tecnologías de informática, comunicaciones y transporte. Los sistemas productivos avanzaron desde el fordismo hacia el posfordismo o el toyotismo, transformando las rígidas y verticales estructuras organizacionales para dar paso a organizaciones más planas, es decir, con menos niveles jerárquicos - dando un mayor empoderamiento a los trabajadores centrado en la autogestión y el autocontrol (Boltanski \& Chiapello, 2002)-, y más flexibles, con capacidad de responder de manera rápida a los acelerados cambios del contexto. Como lo afirman Boltanski y Chiapello (2002),

... los temas de la competencia y del cambio permanente y cada vez más rápido de
las tecnologías $[\ldots]$ adquieren una dimensión sin precedentes, pudiéndose rastrear,
prácticamente en todos los textos, consejos para poner en práctica esta organización
flexible y creativa que sabe "surfear" sobre todas las "olas", adaptarse a todas las trans-
formaciones, tener constantemente un personal dotado de los más recientes cono-
cimientos y obtener una ventaja tecnológica permanente sobre sus competidores.
(p. 116)

En términos de las relaciones de trabajo, en aquella época "la creatividad, la reactividad y flexibilidad son las nuevas consignas que hay que seguir" (Boltanski \& Chiapello, 2002, p. 140). Las formas de dirigir se orientaron hacia la creación de mecanismos de autocontrol y autodirección, siendo el papel del jefe el de un facilitador u orientador: "las nuevas organizaciones han de solicitar todas las capacidades de la persona, que podrá, de este modo, desarrollarse plenamente" (Boltanski \& Chiapello, 2002, pp. 140-141). Las imágenes del mundo del trabajo y de la gestión empresarial a partir de la década de los noventa son lo líquido, lo incierto, lo inestable y lo ligero. En la gestión de las organizaciones ya no se tiene un énfasis en la tarea sino en los 
procesos, lo que lleva a que los trabajadores tengan que estar capacitados para lograr movilidad a través de estos. De esta manera, surge un concentrado interés por el tema del desarrollo de las competencias.

De otra parte, dado que el pacto social presente en la década de los años sesenta que implicaba un Estado de bienestar y la promesa a los trabajadores de un empleo estable y el desarrollo de una carrera al interior de las organizaciones- ya no está vigente, pues surgen con fuerza procesos de flexibilización de la fuerza de trabajo, el salario y la coacción no son suficientes para motivar el compromiso y el avivamiento del entusiasmo de los trabajadores por el desarrollo de las tareas, por lo que empiezan a desarrollarse mecanismos para lograr la implicación del personal con las organizaciones (Boltanski \& Chiapello, 2002), siendo uno de ellos el argumento de la libertad que pueden experimentar los trabajadores al verse disminuidos los procesos de influencia directa por parte de los jefes.

\footnotetext{
En el nuevo universo todo es posible, ya que la creatividad, la reactividad y la flexibilidad, son las nuevas consignas que hay que seguir. Nadie se encuentra ya limitado por su pertenencia a un servicio concreto ni se encuentra sometido por completo a la autoridad de un jefe, porque todas las fronteras son transgredibles gracias a los proyectos. (Boltanski \& Chiapello, 2002, p. 140)
}

Este panorama determinó nuevas formas de relacionamiento en los ámbitos laborales, mediadas por múltiples formas de contratación, aunque se mantiene la relación de subordinación como base de lo laboral. Aunque se dio una mayor autonomía a los trabajadores para sobreponerse a la rutinización y sobre-especialización en las funciones derivadas del sistema taylorista, esta fue también una estrategia para la disminución de costos derivada de un menor número de niveles jerárquicos. Como lo afirman Boltanski y Chiapello (2002), "los autores de gestión empresarial de la década de los noventa $[. .$.$] imaginan [. .$.$] una gran cantidad de nuevas formas de$ organización que se alejan lo máximo posible de los principios jerárquicos" (p. 116).

De otra parte, la flexibilización de la fuerza laboral en esta época también conllevó una individualización en las relaciones de trabajo, condición que se ha mantenido y ha crecido hasta el presente. Asimismo, emergieron estrategias como la "autonomía controlada", condición que implica formas de "administración a distancia" (Pagès, Bonetti, De Gaulejac \& Descentre, 1993).

Las transformaciones en la gestión de las organizaciones que empezaron a ocurrir a partir de los años noventa, derivadas principalmente del auge de las tecnologías de la informática y las comunicaciones, conllevó a la complejización en las relaciones de trabajo, condición que impulsó el estudio del contrato psicológico, ya que este 
concepto aparecía como una categoría clave para la comprensión de las complejas relaciones de trabajo que empezaban a configurarse por aquella época.

Una de las razones es la multiplicidad de formas de contratación y la aparición de formas cada vez más flexibles de gestión, razón por la cual Rousseau (1989) sostiene que "cada vez más, la relevancia de los temas contractuales dentro y entre organizaciones sugiere una necesidad de explicar el rol de los contratos subjetivos en la investigación y teoría organizacional" (p. 123); además, sugiere que "es tiempo de valorar de nuevo nuestros supuestos sobre los contratos. Los contratos tradicionales de empleo han ido cambiando debido a las resestructuraciones de las corporaciones y el declive en las organizaciones de trabajadores" (Rousseau, 1995, p. xi). En este mismo orden de ideas, para Alcover (2002), los cambios en los ámbitos de trabajo han producido un aumento en el interés por el contrato psicológico, concepto que se usa, según este autor "para referirse, en general, a los intercambios que de manera implícita se encuentran implicados en toda relación laboral que se establece" (p. 26).

Las condiciones presentes en esa época marcaron importantes y drásticos cambios en el ambiente de los negocios, lo que llevó también a profundas transformaciones en la conformación de las organizaciones y, concomitantemente, de las relaciones de trabajo. Los programas de reingeniería orientaron la reestructuración de las organizaciones y tomaron fuerza procesos de flexibilización de la gestión del trabajo.

\section{Con las nuevas organizaciones, la prisión burocrática estalla; se trabaja con personas de la otra punta del mundo, de otras empresas o de otras culturas. El descubrimiento y el enriquecimiento pueden ser permanentes. Asimismo, las nuevas "relaciones elec- trónicas" a distancia se revelan incluso más sinceras y más libres de lo que eran las relaciones cara a cara. (Boltanski \& Chiapello, 2002, p. 140)}

Esta reconfiguración, flexibilización y sobre todo la individualización de las relaciones de trabajo, trae consigo nuevos retos para la comprensión de las mismas y hay que asir todos los recursos teóricos disponibles para ello. En tal sentido, se busca en el ático de las teorizaciones sobre gestión de las organizaciones algo que puede servir al propósito de comprender y explicar los fenómenos y hechos sociales que ocurren, y se encuentra entonces que el concepto contrato psicológico puede llenar los vacíos de conocimiento existentes, no obstante que requiere de ciertos ajustes y modificaciones.

La década de los noventa, igual que las anteriores, requiere del involucramiento y compromiso de los trabajadores con sus organizaciones, solo que ahora se impone una individualización de las relaciones de trabajo con la elaboración de discursos como el de la empleabilidad y la autonomía, que centran el esfuerzo en el propio 
desarrollo de los trabajadores y la construcción y gestión de su carrera en el propio individuo, desligando de esta responsabilidad a las organizaciones (Rentería \& Malvezzi, 2008), condición que está expresada en el concepto de empleabilidad.

Tal individualización en las dinámicas de trabajo trae consigo la necesidad administrar de manera eficaz al individuo en relación con su puesto de trabajo, por lo que la organización requiere entonces contar con instrumentos y mecanismos que le permitan medir y evaluar las capacidades de cada persona con el propósito de fortalecer y desarrollar aquellos aspectos identificados como esenciales para la competitividad organizacional, por lo que la gestión por competencias se propone como una herramienta de gestión que podrá facilitar el logro de estos propósitos.

De esta manera, la conceptualización del contrato psicológico centrada en una perspectiva individual responde a las características y condiciones de individualización y empoderamiento prevalecientes en la época, en materia de gestión de las personas en las organizaciones.

\section{CUARTO PERIODO: CUESTIONAMIENTOS AL CONCEPTO}

Posterior a este resurgimiento del interés por el contrato psicológico en la década de los noventa, los años siguientes estuvieron marcados por algunas discusiones y críticas en torno a la definición del concepto. Entre el final de la década de los noventa y principios del siglo XXI, varios autores (Arnold, 1996; Conway \& Briner, 2005; Cullinane \& Dundon, 2006; Guest, 1998) proponen algunas críticas a las definiciones hechas sobre este concepto, siendo especialmente el foco del análisis el tema de la mutualidad en el contrato psicológico, dado que un "contrato" implica el concurso de dos partes y esto no siempre se ha hecho evidente en las definiciones propuestas hasta el momento. La crítica sobre este aspecto se hace principalmente al trabajo de Rousseau, ya que esta autora es quien fundamentalmente sostiene una conceptualización del contrato psicológico centrada en el individuo. En relación con este aspecto, Conway y Briner (2005), afirman lo siguiente:

\footnotetext{
[E]l rol de mutualidad es importante porque determina el nivel de análisis más apropiado. Si el contrato psicológico es predominantemente un constructo subjetivo, entonces el análisis a nivel individual parece más apropiado. Si involucra acuerdos entre las partes, entonces el análisis a nivel relacional (por ejemplo creencias contractuales que son formadas por ambas partes) puede ser más apropiado. (Conway \& Briner, 2005, p. 29)
}

$\mathrm{Al}$ respecto, Rousseau (1990) sostiene que "los contratos psicológicos existen en el ojo del observador y es en ese nivel (individual) que las creencias en los contratos 
psicológicos son postuladas y afectan tanto actitudes como comportamiento. La mutualidad no es una condición necesaria” (p. 391).

La conceptualización del contrato psicológico centrada en el individuo ha sido criticada también por Cullinane \& Dundon (2006), en el sentido en que, si el contrato psicológico implica una relación entre dos partes, el análisis desde el individuo deja por fuera a la otra parte, lo que constituye en sí una paradoja, según se desprende de las ideas plateadas por estos autores:

\footnotetext{
En términos legales, la noción de contrato implica un acuerdo, o al menos la apariencia externa de un acuerdo. Sin embargo, dado que el contrato psicológico está orientado hacia las percepciones subjetivas - o como Rousseau $(1995$, p. 6) ha afirmado "el acuerdo está en el ojo del espectador" - el potencial para la investigación de tal acuerdo o encontrar la "zona de aceptación" es inherentemente problemático. (Cullinane \& Dundon, 2006, p. 118)
}

La noción de mutualidad también está presente en las propuestas de Argyris, Levinson et ál. y Schein. Cabe señalar aquí particularmente la perspectiva de Schein, para quien el contrato psicológico implica un conjunto de "expectativas mutuas" (Schein, 1982, p. 135) que ocurren entre el trabajador y la organización, lo cual, a juicio de Arnold (1996), "implica que los puntos de vista tanto del individuo como de la organización están involucrados, y emerge la cuestión recurrente de exactamente quién constituye la organización como una parte del contrato psicológico" (p. 512). Pero si se tiene en cuenta que las relaciones de trabajo en la actualidad se llevan a cabo en muchos casos con más de un empleador, o como ocurre en condiciones de tercerización en que las tareas se realizan a través de contratistas, o en el trabajo por proyectos en el que un individuo puede pertenecer a varios proyectos y tener así que responder a más de un líder, surge la pregunta de ¿quién es la organización? Como lo afirman Conway y Briner (2005) "si bien existe acuerdo sobre quién representa el empleado, es menos claro qué constituye la organización, y el asunto de si las organizaciones pueden tener un contrato psicológico permanece en un área de permanente controversia" (p. 33).

Para Rousseau (1995) no existe conflicto al momento de identificar "la organización" como contraparte del contrato psicológico, ya que en ella, "aunque propietarios/ empleadores crean sus propios contratos con empleados individuales, la mayoría de quienes hacen contratos son individuos actuando como agentes de las organizaciones" (p. 60). Esta propuesta es criticada por Guest (1998), para quien hablar de agentes representantes no resuelve el problema, puesto que en las organizaciones puede haber diversos tipos de agentes que actúan como representantes de la organización, razón por la cual, según este autor, un empleado podría tener varios contratos 
psicológicos, uno con cada agente representante, lo cual inhabilita la existencia de una sola parte tipificada como "la organización".

Este es un asunto bastante complejo, pues implica también cuestiones de orden ontológico, ya que la concebir la organización como esa otra parte en el contrato psicológico puede evidenciarse que esta y el trabajador son diferentes en su naturaleza (Vesga, 2014). Por una parte, está la persona única, particular y singular como la denomina Barnard (1968) y, de otra, se encuentra la organización como una construcción social y artificial, como producto intersubjetivo resultante de un complejo sistema de relaciones (Spink, 1996). Dado que la vida cotidiana se presenta como un "mundo intersubjetivo" (Berger \& Luckmann, 1995, p. 40), tal intersubjetividad necesariamente se da entre dos o más sujetos, y en tal sentido "la organización" no puede experimentar subjetividad puesto que no es un individuo, sino un ente abstracto que tiene una naturaleza ontológica diferente a la de un sujeto humano.

Lo que se conoce como "organización" es un ente artificial cuya existencia se basa en el "uno" tal como lo propone Heidegger: "En la cotidianidad del Dasein la mayor parte de las cosas son hechas por alguien de quien tenemos que decir que no fue nadie" (Heidegger, 2009, p. 147). Esto significa, por ejemplo, que si bien las decisiones, políticas y directrices en la organización surgen de una persona y son escritas por ella, estas no se conciben como emanadas de un solo individuo por parte de los trabajadores, sino de un ente generalizado que se define como "la gerencia", "recursos humanos" o simplemente "la empresa", entre otros apelativos. De esta manera, la identidad de un sujeto que ha creado y escrito una norma que debe ser acatada por los miembros de una organización queda diluida en la identidad colectiva del "uno", que es "la organización", y así, "el uno se revela como 'el sujeto más real' de la cotidianidad" (Heidegger, 2009, p. 148). El contrato psicológico se establece, en esta perspectiva, entre el trabajador y un "otro" que es la organización, objetivado a través de las políticas y prácticas de recursos humanos, que son las que regulan las relaciones de trabajo en la organización, la cual es percibida por el trabajador como un "otro generalizado" (Mead, 1934, p. 154), pero personificada en el directivo de recursos humanos como agente representante de la organización ante los trabajadores, quien es el encargado de establecer las directrices que regulan las relaciones de trabajo en una organización.

Otras miradas críticas han surgido en materia de los abordajes metodológicos usados para estudiar el contrato psicológico. Estas parten del hecho de que Denise Rousseau, quien es la autora que ha tenido la más importante influencia teórica, y por lo tanto metodológica, en el uso e investigación del concepto a partir la década de los noventa del siglo pasado, se propuso en su momento "ofrecer una teoría conductual 
de contratos para ayudar a académicos y gerentes en la dirección de los roles fundamentales que los contratos juegan en las organizaciones" (1995, p. xi), lo cual ha incidido en una tendencia a abordar el estudio del contrato psicológico con un enfoque predominantemente cuantitativo. En este sentido Taylor \& Tekleab (2004) sostienen que "mucha de la investigación sobre contrato psicológico parece haber fallado en una ruta metodológica" (p. 279), debido a que "los investigadores del contrato se han centrado más en la prueba empírica de las proposiciones existentes que en un refinamiento de las propuestas conceptuales y el desarrollo de modelos conceptuales más comprensivos" (p. 280).

\section{Quinto periodo: lecturas alternativas del concepto}

En las dos primeras décadas del presente siglo se han propuesto lecturas alternativas al hecho social de los acuerdos y pactos en las relaciones de trabajo y en la forma de concebir y definir el contrato psicológico.

Conway \& Briner (2005) proponen dos referenciales teóricos como alternativa a los abordajes de corte cuantitativo para el estudio del contrato psicológico que, de acuerdo con estos autores, permitirían concebir el contrato psicológico desde miradas más cualitativas. Ellos son las autonarrativas de K. Gergen y M. Gergen (1988) y la perspectiva de construcción de sentido de Weick (1995). Al respecto, Conway y Briner (2005) afirman:

Gergen \& Gergen (1988) argumentan que los individuos usan narrativas para dar sentido a sus relaciones sociales y estas narrativas, a su vez, informan cómo los individuos entienden quiénes son, referido como el "self" [cursivas añadidas] [...]. A través de ver las interacciones sociales como narrativas, los individuos se posicionan en roles y desarrollan nociones del self [cursivas añadidas]. Gergen y Gergen usan el concepto de autonarrativas [cursivas en el original] para definir estos procesos, los cuales refieren a lo que "los individuos" reportan sobre la relación entre los eventos auto-relevantes a través del tiempo. (p. 142)

Desde esta perspectiva, las narrativas dan sentido a las relaciones sociales. Por su parte, para Gergen (1996) el lenguaje es clave en la construcción de significados y sentidos, pero esta construcción solo ocurre en el marco del intercambio social, de la interdependencia relacional, pues como lo afirma este mismo autor,

... el lenguaje significativo es el producto de la interdependencia social, exigiendo las acciones unas coordenadas formadas al menos por dos personas, y hasta que no existe un acuerdo mutuo sobre el carácter significativo de las palabras, no logran constituir 
el lenguaje. [...] la certeza que poseemos no la proporciona la mente del individuo singular, sino que más bien resulta de las relaciones de interdependencia. (p. 2)

En esta perspectiva, las autonarrativas aparecen como un mecanismo fundamental para comprender tanto el mundo intrasubjetivo de los sujetos como aspectos de la interacción social. Para Gergen (1996) las autonarraciones son recursos conversacionales, "recursos culturales que cumplen con ese tipo de propósitos sociales como son la autoidentificación, la autojustificación, la autocrítica y la solidificación social" (p. 165).

Es posible ver la comprensión que un trabajador tiene de su contrato psicológico como una autonarrativa para entender los altos y bajos de la relación de trabajo. Existen algunos beneficios del enfoque de autonarrativas para la comprensión del contrato psicológico, pues las autonarrativas vinculan la evolución continua del contrato psicológico con su identidad, sirven para predecir posibles trayectorias futuras, pueden proveer pistas de cómo los individuos usan teorías acerca del contrato psicológico y permiten mostrar el despliegue de eventos del contrato psicológico (Conway \& Briner, 2005).

De otra parte, respecto a la construcción de sentido de Weick (1995), Conway y Briner (2005) afirman que esta perspectiva permite la comprensión de los contratos psicológicos debido a que los sentidos son socialmente construidos, y evidentemente los contratos surgen en el marco de las relaciones de trabajo en un sistema social que es la organización. De esta manera,

La perspectiva de la construcción de sentido de Weick se enfoca en cómo la gente da sentido a los eventos y situaciones en las organizaciones. [...] La construcción de sentido se activa cuando los individuos encuentran sorpresas, choques, o más generalmente una discrepancia entre lo que ellos perciben que ha pasado y lo que esperaban que pasara. Tales discrepancias crean una necesidad de información, explicación, interpretación y consecuente acción constituyendo los procesos de construcción de sentido. (Conway \& Briner, 2005, p. 148)

Para Weick (1995), la construcción de sentido presenta siete características que diferencian este concepto de otros procesos explicativos tales como entendimiento, interpretación y atribución. De esta manera, la construcción de sentido es entendida como un proceso que 1) está fundamentado en la construcción de identidad, es decir, implica un sujeto que construye sentido; 2 ) es retrospectivo, lo que implica que está basado en las experiencias vividas; 3 ) implica el establecimiento de ambientes perceptibles, el cual se relaciona con la promulgación de normas que determinan espacios, tiempos y líneas de acción, establecen categorías y etiquetas clave que crean nuevas 
características en el ambiente que no existían antes; 4) es social, lo que implica contingencias entre las acciones de los sujetos en un contexto social determinado y que los significados son socialmente construidos; 5) es continuo, fluye constantemente; 6) es focalizado sobre y por señales extraídas del contexto, las cuales se refieren a estructuras familiares para los sujetos que actúan como piezas clave de información; y 7) es regido por plausibilidad más que por exactitud, es decir, prima más la credibilidad que tiene un fenómeno para los sujetos que su precisión (Weick, 1995).

Cada una de estas características puede, a juicio de Conway \& Briner (2005) ayudar a entender los contratos psicológicos en las organizaciones. La primera puede ser entendida en condiciones de percepción de incumplimiento del contrato psicológico, puesto que este se constituye en una amenaza a la identidad, entendida como la búsqueda de objetivos valorados, y si las organizaciones fallan en el cumplimiento de las promesas esto frustra el progreso de los trabajadores hacia sus objetivos. La segunda característica subraya la importancia de las experiencias pasadas en la percepción presente del contrato psicológico. La tercera sugiere cómo las acciones del empleado son interpretadas por la organización y viceversa, lo cual contribuye a la formación de los contratos psicológicos. La cuarta característica es clave en el sentido en que la formación de contratos psicológicos es un proceso social, que se enmarca en las dinámicas de la interacción social en las organizaciones. La quinta implica que la formación del contrato psicológico es un proceso continuo y dinámico, que se transforma a partir de las continuas experiencias del sujeto con la organización. La sexta sugiere que los sujetos exploran su entorno en la búsqueda de señales que dan sentido a sus relaciones de trabajo. Finalmente, la séptima característica sugiere una condición opuesta a la percepción de incumplimiento del contrato psicológico, puesto que este implica percepciones sociales y buscar exactitud en tales percepciones es fútil (Conway \& Briner, 2005).

Por su parte, Guest (2004) manifiesta que el contrato psicológico no puede ser analizado de manera aislada, sino que es necesario desarrollar una estructura analítica que tenga en cuenta además el contexto, involucrando variables tanto en el nivel individual como en el organizacional; el autor afirma que "el contexto no solo ayuda a dar forma al contenido del intercambio que forma el contrato psicológico, sino también las respuestas al mismo" (p. 549). De esta manera, propone una estructura para el análisis y comprensión del contrato psicológico en una perspectiva ampliada.

Tal estructura, de acuerdo con el autor, considera no solo el contrato psicológico en sí, sino también su contexto, lo cual permite explorar sus causas, naturaleza y consecuencias. Como antecedentes, es necesario tener en cuenta aspectos organizacionales como la estrategia de negocios, sector de la economía a la que pertenecen la 
organización y sus políticas y prácticas de recursos humanos, y asimismo aspectos individuales del trabajador como el nivel del cargo, la clase de trabajo que realiza y el tipo de contrato, entre otros, aspectos que anteceden a la formación de los contratos psicológicos, los cuales tienen consecuencias actitudinales relacionadas con el nivel de compromiso del trabajador, satisfacción en el trabajo, así como efectos comportamentales asociados a las conductas de ciudadanía organizacional, desempeño laboral e intención de permanecer o abandonar la organización (Guest, 2004).

El propósito de Guest (2004) al presentar este modelo del contrato psicológico es proveer un marco de análisis amplio dentro del cual pueda entenderse el contrato psicológico en un contexto en el cual se exploren las relaciones de trabajo en el siglo XXI. Esta propuesta permite ver el contrato psicológico como parte de un proceso y entender que existen elementos antecedentes que contribuyen a su formación, así como sus correspondientes efectos tanto para el trabajador como para la organización de la cual forma parte. En tal sentido, el contrato psicológico se observa como un elemento más de un complejo mucho más amplio que son las relaciones de trabajo.

Otro autor que ha elaborado una propuesta alternativa a las definiciones y miradas tradicionales del contrato psicológico es Malvezzi (2011). Para este autor, "uno de los elementos que diferencian la sociedad moderna de esta que emerge en el siglo XXI es la sustitución de dependencia de las instituciones colectivas, como las tradiciones e ideologías, por las negociaciones y contratos psicológicos" (p. 68). En tal sentido, estaría ocurriendo una mutación de una sociedad gobernada por las antiguas instituciones y las tradiciones a una regulada por los acuerdos y negociaciones transitorias. Para este autor,

\section{... esa nueva gramática del contexto social eleva los contratos psicológicos al estatus de instrumento estratégico de la vida social porque, siendo esta compleja e imprevisí- ble, el adelgazamiento del vínculo con las instituciones requiere de otros instrumentos reguladores y gestionadores de las relaciones interpersonales. (Malvezzi, 2011, p. 68)}

En este contexto, el contrato psicológico emerge en la actualidad como un mecanismo regulador de las relaciones de trabajo, afectadas por la flexibilización en los procesos de contratación y por lo que Bauman (2007) ha denominado "fragilidad de los vínculos humanos" (p. 7). Esta regulación puede lograrse a través del establecimiento de "acuerdos tácitos" que permitan lograr el compromiso de los trabajadores en la dinámica organizacional. De esta manera, el contrato psicológico actúa como puente de enlace entre los individuos y entre ellos y las organizaciones, lo cual implica la construcción de vínculos a través del establecimiento de compromisos mutuos. En tal sentido, Malvezzi define los contratos psicológicos como 
... los vínculos estables, implícitos y voluntarios de cooperación mutua entre individuos y grupos. Tales vínculos nacen y son regidos por la regularidad de intercambios recíprocos entre ellos, que poco a poco van construyendo y revelando algún compromiso duradero aceptado por las partes. (p. 69)

Esta propuesta lleva a pensar que, en el contexto actual de las relaciones de trabajo, el contrato psicológico puede ser concebido como algo más que una simple extensión del contrato jurídico, instituyéndose como una forma de vínculo psicológico de los individuos con la organización a través de las relaciones de intercambio con otros, dando así sentido y trascendencia a las relaciones de trabajo. En este orden de ideas, Malvezzi (2011) sostiene que "el contrato psicológico 'se torna visíble' cuando el individuo constata alguna trascendencia entre él y otro individuo, o grupo" (p. 68).

En una perspectiva similar a la de Guest (2004), Chiuzi (2014) propone el análisis y comprensión de los contratos psicológicos en el marco de un modelo que implica su génesis, evolución y ajuste permanente. Para este autor, los contratos psicológicos son "un conjunto de obligaciones mutuas entre empleado y empleador, comprendido como un fenómeno relacional, subjetivo, dinámico, mayormente implícito y no verbalizado, existente en situaciones de intercambio en el trabajo" (Chiuzi, 2014, p. 123). Cabe destacar, en esta propuesta, la mirada del contrato psicológico como un fenómeno relacional y dinámico, ya que el mismo ocurre en la trama de las interacciones cotidianas de los sujetos laborales en sus contextos de trabajo, y se evidencia como un proceso de ajuste continuo en la medida en que cambian las condiciones laborales.

Para este autor, la formación de un contrato psicológico comienza antes del ingreso de la persona a la organización, y está influenciado por experiencias laborales previas que haya tenido el individuo; sin embargo, es en el lugar de las actividades durante el proceso de selección, particularmente las entrevistas, donde comienza a configurarse el contrato psicológico con la organización a la que el individuo aspira a ingresar. De esta manera, "el sentimiento de derechos y obligaciones es fundamentado a partir de esas experiencias previas y predisposiciones idiosincrásicas que fueron aprendidas [...] [por lo que] los factores individuales, organizacionales y contextuales son pilares en la formación de los contratos psicológicos" (Chiuzi, 2014, p. 125); esto implica que la configuración propiamente dicha del contrato psicológico entre un trabajador y su organización tiene elementos antecedentes que fundamentan la formación actual del mismo.

Posterior al proceso de selección, una vez que el individuo ya forma parte de la organización como trabajador de la misma, el contrato psicológico mantiene una dinámica de ajuste permanente, siendo "el cotidiano" que experimenta el sujeto en su relación de trabajo un elemento importante en la propuesta de Chiuzi. Pero tal dinámica, 
no implica etapas sucesivas o episodios definidos y claramente delimitados que se presentan en secuencia a través del tiempo. Para este autor, su modelo "considera las dinámicas de continuidad y ajustes de los contratos psicológicos como una interacción de diversos fenómenos que crean una danza donde evaluaciones, formación, monitoreo y diversificaciones ocurren simultáneamente" (Chiuzi, 2014, p. 140).

Otra de las tendencias presentes en la literatura de la psicología organizacional actual en las que se proponen alternativas a la forma de ver y entender el hecho social de los acuerdos y pactos en las relaciones de trabajo, lo que incluye el propio contrato psicológico, pueden verse en las reflexiones y discusiones sobre los idiosyncratic deals o "acuerdos idiosincrásicos", los cuales son acuerdos personales individualizados entre la organización y trabajadores considerados valiosos por la misma. Para Rousseau (2001), la idea de este tipo de acuerdos revela importantes aspectos de la dinámica de negociaciones particulares y específicas entre trabajadores y sus empleadores, como el hecho de que pueden darse diferentes acuerdos para diferentes personas aunque ellas hagan un trabajo similar, ya que existen trabajadores que buscan ganar flexibilidad negociando acuerdos que satisfagan mejor sus propios intereses y necesidades personales al tiempo que contribuyen de manera más efectiva a la organización.

De acuerdo con esta autora, este tipo de acuerdos "pueden ser tanto objetivos como [por ejemplo] diferente pago por el mismo trabajo, como subjetivos, como el apoyo y flexibilidad que un supervisor da a algunos trabajadores y no a otros" (Rousseau, 2001, p. 262). Sin embargo, una característica fundamental en este tipo de acuerdos es que ocurren de manera individualizada y personalizada con cada trabajador con el que se negocia, y no son producto de negociaciones colectivas entre la organización y grupos de trabajadores como los sindicatos. Anteriormente este tipo de acuerdos se daban con los trabajadores más antiguos como producto de una amplia relación laboral al interior de la organización, y se daban principalmente en términos de salarios más altos o trato preferencial, pero en la actualidad ocurren como estrategia de atracción y retención de personal considerado valioso para las organizaciones en un mercado de trabajo altamente competitivo, e incluyen características más allá del pago como desarrollo de habilidades, viajes, tiempo libre, flexibilidad de horarios o viajes y movilidad (Rousseau, 2001).

Alcover, Rico, Turnley y Bolino (2016), con base en la reflexión de que las relaciones de trabajo toman en la actualidad múltiples formas, y puesto que el contrato psicológico es un mecanismo para hacer lectura de las relaciones de trabajo, afirman que se requiere un abordaje multifoco para comprender las relaciones de intercambio implícitas en la formación de contratos psicológicos. Esta propuesta marca un paso de la mirada tradicional de las relaciones de intercambio entre individuos y organizaciones 
a un abordaje que reconoce la existencia de múltiples miradas o "focos" en las relaciones de intercambio en el trabajo. Como lo afirman estos autores,

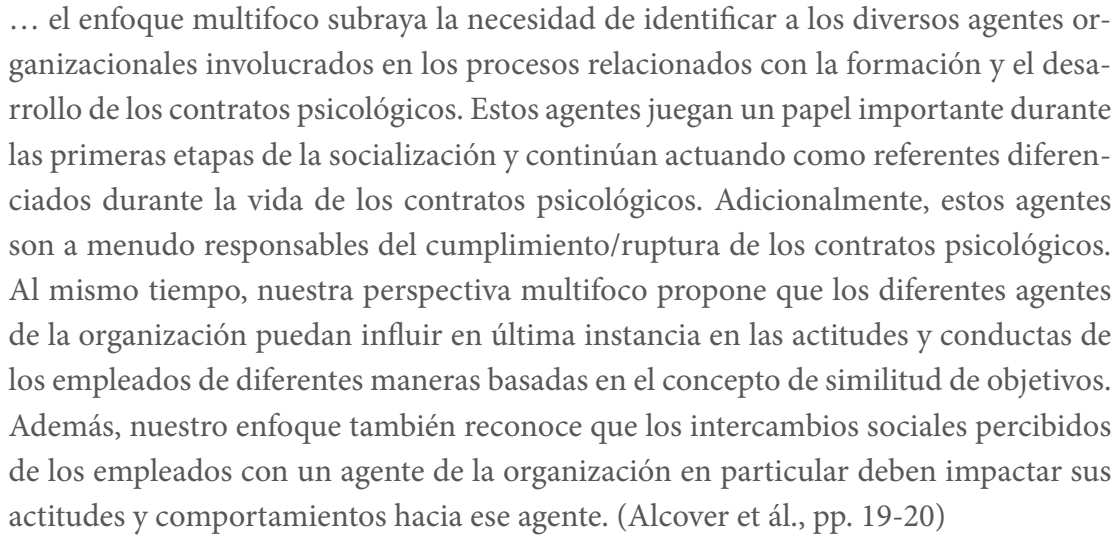

Este abordaje multifoco está en línea con la propuesta de Vesga (2017) de entender el contrato psicológico como un "concepto multidimensional" (p. 297). Desde esta perspectiva, el contrato psicológico ha sido concebido en la literatura con base en relaciones diádicas trabajador-jefe o trabajador-organización, pero como lo presentan Alcover et ál. (2017), las relaciones de trabajo son complejas y diversas, y puesto que el contrato psicológico como concepto hace lectura de estas relaciones, la cotidianidad del trabajador se experimenta como una diversidad y complejidad de relaciones que impactan la formación de contratos psicológicos:

\begin{abstract}
En un mundo conexionista como el de hoy, las relaciones de trabajo no se configuran de manera diádica, sino que involucran un conjunto diverso de interacciones con diferentes actores de las dinámicas laborales. Cada trabajador configura una red de relaciones con compañeros de trabajo, directivos, clientes, proveedores, empleados temporales, miembros de otras organizaciones vinculados mediante outsourcing y contratistas, entre otros. (Vesga, 2017, p. 303)
\end{abstract}

En este orden de ideas, el contrato psicológico como concepto multidimensional propone una alternativa más actualizada como mecanismo de lectura de las complejas y variadas relaciones de trabajo que se tejen en la actualidad.

Rentería y Vesga (2019) desarrollan una idea similar a los abordajes multifoco (Alcover et ál., 2017) y de concepto multidimensional (Vesga, 2017), al presentar una perspectiva multinivel para el análisis y comprensión de los contratos psicológicos en contextos laborales. Los autores parten de la propuesta de Rentería y Carvajal (2006) de la existencia de diversos niveles de actuación y análisis, individual, ocupacional, 
divisional, organizacional y contextual, en los que se desenvuelven las relaciones de trabajo en las organizaciones. Rentería y Vesga (2019) proponen "el análisis de la estructuración de las relaciones de trabajo a través de diversos niveles de actuación, como encuadre para la comprensión de la formación de contratos psicológicos" (p. 129). De esta manera, cada uno de los niveles en que se desenvuelven las relaciones de trabajo consituye marcos de referencia y actuación que proveen elementos psicosociales que inciden en la formación de contratos psicológicos.

Estas lecturas alternativas en la conceptualización del contrato psicológico proveen nuevos e interesantes abordajes para la comprensión contextualizada de este concepto, entendiendo lo contextualizado no solo en términos de los ambientes laborales especificos que forman la base de la experiencia laboral cotidiana de los trabajadores, sino también en función del momento histórico en que el concepto intenta ser aplicado para la lectura de un fenómeno en particular.

\section{A modo de conclusión}

Como lo han señalado varios autores (Alonso \& Fernández, 2006; Barley \& Kunda, 1992), existe una correspondencia entre las condiciones sociales, políticas, culturales y ante todo teóricas del contexto, y la emergencia y formación de teorías, abordajes, perspectivas o conceptos que intentan explicar tales condiciones; en este mismo sentido, los significados atribuidos a los conceptos son contigentes a los momentos históricos que forman parte del contexto en el que un concepto surge y evoluciona. Como lo ha señalado Kuhn (2002) "los significados son productos históricos, y cambian inevitablemente en el transcurso del tiempo cuando cambian las demandas sobre los términos que los poseen" (p. 51).

En este capítulo se ha mostrado la emergencia, evolución y usos en la literatura especializada del concepto de contrato psiclógico, y se han presentado los elementos contextuales que han acompañado la manera como el uso del concepto se ha transfomado a lo largo de su historia. En tal sentido, se requiere mantener actualizada la discusión sobre el estatuto de las categorías con las cuales se representan las partes implicadas las relaciones de trabajo: trabajador-jefe versus trabajador-organización. En el primer caso se trata de dos actores humanos, y en el segundo de un humano y un ente sociojurídico abstracto.

Las transformaciones, emergencias y reemergencias del concepto y su tratamiento están relacionados con la manera como el fenómeno, derivado de las relaciones de trabajo como relaciones sociales, se hace evidente, obligando a su "reconceptualización" en una tensión por reducir el primero a lo segundo, o porque lo segundo cualifique y describa lo primero de forma actualizada. 


\section{Referencias}

Alcover, C. M. (2002). El contrato psicológico: el componente implícito de las relaciones laborales. Aljibe.

Alcover, C.-M., Rico, R., Turnley, W. \& Bolino, M. (2016). Understanding the changing nature of psychological contracts in 21st century organizations: Amultiple-foci exchange relationships approach and proposed framework. Organizational Psychology Review, 1-32.

Alonso, L. E. \& Fernández, C. J. (2006). El imaginario managerial: el discurso de la fluidez en la sociedad económica. Política y Sociedad, 43(2), 127-151.

Argyris, C. (1960). Understanding organizational behavior. Dorsey.

Arnold, J. (1996). The psychological contract: a concept in need of closer scrutiny? European Journal of Work and Organizational Psychology, 5(4), 511-520.

Barley, S. \& Kunda, G. (1992). Design and devotion: surges of rational and normative ideologies of control in managerial discourse. Administrative Science Quarterly, 37(3), 363399.

Barnard, C. (1968). The Functions of the Executive. Harvard.

Bauman, Z. (2007). Amor líquido: Acerca de la fragilidad de los vínculos humanos. Fondo de Cultura Económica.

Berger, P. \& Luckmann, T. (1995). La construcción social de la realidad. Amorrortu.

Boltanski, L. \& Chiapello, È. (2002). El nuevo espíritu del capitalismo. Akal.

Chiuzi, R. M. (2014). As dinâmicas de formação e continuidade dos contratos psicológicos de trabalho. (Tesis doctoral). Universidade de São Paulo. Instituto de Psicologia. http:// www.teses.usp.br/teses/disponiveis/47/47134/tde-27112014-104051/pt-br.php

Conway, N. \& Briner, R. (2005). Understanding psychological contracts at work: a critical evaluation of theory and research. Oxford.

Coyle-Shapiro, J. \& Parzefall, M. (2010). Psychological contracts. http://eprints.lse.ac.uk/26866/

Cullinane, N. \& Dundon, T. (2006). The psychological contract: a critical review. International Journal of Management Reviews, 8(2), 113-129.

Dávila, C. (2001). Teorías organizacionales y administración: enfoque crítico. McGraw-Hill.

Gergen, K. (1996). Realidades y relaciones: aproximaciones a la construcción social. Paidós.

Gergen, K. J. \& Gergen, M. M. (1988). Narrative and the self as relationship. En: L. Berkowitz (ed.). Advances in Experimental Social Psychology, (vol. 21, pp. 17-56). Academic Press.

Guest, D. (1998). Is the psychological contract worth taking seriously? Journal of Organizational Behavior, 19, 649-664.

Guest, D. (2004). The psychology of the employment relationship: an analysis based on the psychological contract. Applied Psychology, 53(4), 541-555.

Heidegger, M. (2009). Ser y tiempo (2a ed.). Trotta.

Hobsbawm, E. (1998). Historia del siglo XX. Grijalbo Mondadori. 
Jauregizar, J. (1998). El País Vasco. Un modelo de referencia de Europa. En: J. R. Morales \& J. H. Perdomo (ed.). Ciencia, innovación y desarrollo regional. memorias (pp. 167-196). Colciencias.

Katz, D. \& Kahn, R. (1966). The social psychology of organizations. John Wiley \& Sons, Inc.

Kotter, J. P. (1973). The psychological contract: managing the joining-up process. California Management Review, 15(3), 91-99.

Kuhn, T. (2002). El camino desde la estructura. Barcelona: Paidós.

Levine, J. \& Moreland, R. (1990). Progress in small group research. Annual Review of Psycho$\log y, 41,585-634$.

Levinson, H., Price, C., Munden, K., Mandl, H. \& Solley, C. (1962). Men, management, and mental health. Harvard.

López, F. (2002). El análisis de contenido como método de investigación. XXI: Revista de Educación, 4, 167-179.

Malvezzi, S. (2011). A gestão dos contratos psicológicos. Revista do Instituto de Marketing Industrial, 53, 66-73.

McGregor, D. (1994). El lado humano de las organizaciones. McGraw-Hill.

Mead, G. (1934). Mind, self, and society. University of Chicago.

Menninger, K. (1958). Theory of psychoanalytic technique. Basic Books.

Pagès, M., Bonetti, M., De Gaulejac, V. \& Descentre, D. (1993). O poder das organizações. São Paulo: Atlas.

Portwood, J. D. \& Miller, E. L. (1976). Evaluating the psychological contract: its implications for employee job satisfaction and work behavior. Academy of Management Proceedings, $1,109-113$.

Rentería, E. \& Carvajal, B. (2006). Abordaje psicosocial de la diversidad y papel de formas organizativas en contextos organizacionales instituidos. Psicología desde el Caribe, 17, 149-175.

Rentería, E. \& Malvezzi, S. (2008). Empleabilidad, cambios y exigencias psicosociales en el trabajo. Universitas Psycologica, 7(2), 319-334.

Rentería, E. \& Vesga, J. J. (2019). Los niveles de actuación en las relaciones de trabajo y la formación de contratos psicológicos. Diversitas: Perspectivas en Psicología, 15(1), 129-142. doi:10.15332/s1794-9998.2019.0001.10

Rousseau, D. (1989). Psychological and implied contracts in organizations. Employee Responsabilities and Rights Journal, 2(2), 121-139.

Rousseau, D. (1990). New hire perceptions of their own and their employer's obligations: A study of psychological contracts. Journal of Organizational Behavior, 11, 389-400.

Rousseau, D. (1995). Psychological contracts in organizations: understanding written and unwritten agreements. Sage. 
Rousseau, D. (2001). The idiosyncratic deal: flexibility versus fairness? Organizational Dynamics, 29(4), 260-273.

Salas, E., Priest, H., Stagl, D. \& Burke, S. (2007). Work teams in organizations: a historical reflection and lessons learned. En: L. Koppes (ed.). Historical perspectives in industrial and organizational psychology (pp. 407-438). Psychology Press.

Schein, E. (1982). Dinámica de la carrera empresarial. Cambridge: Fondo Educativo Interamericano.

Schein, E. (1990). Consultoría de procesos: su papel en el desarrollo organizacional. (2a ed., vol. 1). Addison-Wesley Iberoamericana.

Schein, E. (1994). Organizational psychology. Prentice-Hall.

Spink, P. (1996). A organização como fenômeno psicossocial: notas para uma redefinição da psicologia do trabalho. Psicologia \& Sociedade, 8(1), 174-192.

Taylor, F. (2003). Principios de la administración científica. Edigrama.

Taylor, M. S. \& Tekleab, A. G. (2004). Taking Stock of Psychological Contract Research: Assessing Progress, Addressing Troublesome Issues, and Setting Research Priorities. In J. A.M. Coyle-Shapiro, L. M. Shore, M. S. Taylor \& L. E. Tetrick (Eds.), The Employment Relationship. Examining Psychological and Contextual Perspectives (pp. 253-283). Oxford.

Vesga, J. J. (2014). Evolución histórica del concepto "contrato psicológico". En: J. J. Orejuela (ed.), Psicología de las organizaciones y del trabajo. Apuestas de investigación (pp. 243260). Editorial Bonaventuriana.

Vesga, J. J. (2017). El contrato psicológico: una propuesta de lectura en el marco de las relaciones de trabajo. (Tesis doctoral). Universidad del Valle.

Vesga, J. J. (2017). El contrato psicológico: un concepto multidimensional. En: E. Rentería (ed.). Entre lo disciplinar y lo profesional. Panorama y experiencias en psicología organizacional y del trabajo en iberoamérica (pp. 297-311). Universidad del Valle.

Weick, K. (1995). Sensemaking in organizations. Sage. 


\section{2 \\ A PSYCHOSOCIAL APPROACH TO PSYCHOLOGICAL CONTRACTS: \\ THEORY AND APPLICATION FOR \\ MODERN ORGANIZATIONS}

Rafael Chiuzi*

University of Toronto Mississauga

Department of Management

Institute for Management and Innovation (IMI)

\section{Introduction}

I'll try to be "less academic," as I believe my readers have had ample opportunity to review and reflect on the roots of psychological contracts. From Argyris (1960) seminal work to the ideas of Denise Rousseau (1995), there has been much debate about this highly complex and slippery concept.

The foundational concepts of psychological contracts were developed by early researchers, such as Argyris (1960), Levinson, Price, Munden, and Solley (1962), and Schein (1965); these concepts allowed later researchers, such as Kotter (1973), Rousseau (1995), Robinson (1996), and Guest $(1998,2004)$, to deepen our understanding of psychological contracts, particularly their dynamics. Indeed, there has been considerable research in this area since its inception, with numerous special editions having been dedicated to it in respected peer-reviewed journals like Human Resource Management (1994), Human Resource Management Journal (1994), European Journal of Work Psychology (1996), and the renowned Journal of Organizational Behaviour (1998, 2003).

This chapter aims to present the findings of a four-year study that was conducted with managers from different organizations and their teams in a practical and easyto-read manner. At the end of this chapter, I will also discuss how the psychological contract framework can be applied in modern organizations.

\footnotetext{
${ }^{*}$ https://orcid.org/0000-0002-3111-0072
} 


\section{Contextual considerations about the world of work}

Advancements in robotics, artificial intelligence (AI), data analytics, and many other fields figure prominently in our modern understanding of the business landscape. This is not a surprise, as all narratives point in one direction: the world of work as we know it is changing. This has led some commentators to take a rather gloomy view of the future that is marked by the massive extinction of jobs and global crises spurred by mass unemployment due to structural changes. In contrast, others have taken a highly optimistic outlook based on the belief that people will learn new skills and apply for new jobs, with machines only being used to replace less complicated activities. While only time will tell which group is correct, one thing is clear: the human labour force is being replaced by machines. This is supported by a recent report published by McKinsey (2017), which predicts that approximately one-third of all work activities will be displaced due to technological advancements in robotics by the year 2030 .

I am inclined towards a more middle-of-the-road view. Yes, some jobs will be taken over by AI and robots, but many others will be created in their place. Some workers will be left unemployed, while others will thrive in this new business ecosystem. But then, hasn't this been the case since the dawn of the Industrial Revolution? In my over 14 years of teaching, I have seen many instances of this panic. For example, I remember how some professors thought that computers (especially PowerPoint presentations) and other technological innovations would render them obsolete. Well, here we are, and the position of Professor does not appear to be in danger of turning up on the "Endangered Occupations" list any time soon.

Organizations are increasingly shifting towards horizontal designs, and the prevailing entrepreneurial mindset has formed a new business ecosystem. Consequently, these developments have produced some notable psychosocial changes in the workforce. As a coping mechanism, many companies have developed new ways of doing business in order to deal with these fast-paced changes. The amplification of technologically mediated relations brings with it several hurdles such as the extreme flexibilization of working hours, like getting called on Skype after dinner, or the managing of the company's image online. Perhaps the largest of these hurdles is the basic fact that people would rather not only interact with machines. Indeed, no matter what the business is.

Amid all, one factor remains as a constant: human relationships and work interactions. No matter what the business is, how much money it makes, or the environment it is in, people still want to talk and work with other people. In addition, the workplace continues to be defined by interpersonal relationships: managers must manage 
people and processes; employees have bosses who direct them and to whom they must report; and both employees and managers are tied into macro-level structures serving, for example, the interest of shareholders and an ever-increasing demanding customer base. Given these relationships, the importance of discussing modern approaches to psychological contracts in the workplace becomes clear.

\section{Psychological contracts today}

According to Rousseau $(1997,2001)$, many macro-level forces manifest themselves in the form of changes in how work is organized; for example, the substitution of traditional employment arrangements for inter-organizational networks-which are capable of expanding and contracting due their use of a flexible workforce-or the weakening of unions across the globe as a result of the individualization of work relations. Such changes affect the way people are hired, managed, paid, and dismissed.

These changes have led to the erosion of external guidelines for human behaviour at work, which has in turn given rise to the need for more robust internal guidelines capable of operating within the fluid boundaries of modern organizations. Thus, this erosion of external instructions has led to the tendency for organizations to value change and learning over the traditional strict rule-based processes.

In this volatile, uncertain, complex, and ambiguous (VUCA) situation, the psychological contract emerges as a suitable alternative to the traditional post-industrial model for managing people. Guest (2004) identifies five features of this new environment that explain why psychological contracts are an effective mechanism for leading people within it: i) smaller numbers of employees have made unionization difficult, as there is a direct channel between employees and management; ii) a shift towards a more flexible workforce, which has given rise to several types of contracts related to aspects of employment such as hours of work, wages, exceptions, and physical location; iii) an increased urgency in change efforts due to market dynamics; iv) the growing interest in work-life balance; and v) the decline of collective negotiations in non-unionized workplaces.

In other words, organizations need new people-management models, and the psychological contract approach fills this need particularly well because it is highly adaptable to the dynamic and complex conditions of the modern business landscape. As Hiltrop (1995) explains, psychological contracts accomplish two tasks: they define the employment relationship and manage mutual expectations. Put simply, employers want to know in advance what kind of outputs they will get from employees, and 
employees want a clear sense of the rewards they will get from investing their time and effort into the organization (p. 287).

Before diving into Chiuzis model, a couple of relevant questions must be answered:

1. How do psychological contracts manifest in the workplace? (i.e. how do we know for sure that there is such a thing as a psychological contract?)

2. How can psychological contracts be categorized and defined?

The first inquiry takes us to a very shady area, as the psychological contract is a somewhat subjective phenomenon. As such, the existence of a psychological contract can only be determined by analyzing human agency, narratives, and other manifestations in a social context. Perhaps the most concrete determinant of whether a psychological contract exists between parties is when there is a discrepancy between what is expected and what actually occurs in a given situation. That is, the most tangible manifestation of a psychological contract occurs when one party (or both) considers it to have been breached.

Not surprisingly, contract breaches have been one of the most investigated issues in the recent psychological contract literature. Breaches are primarily associated with a number of constructs, such as organizational justice (Akremi \& Ameur, 2005; Tekleab, Takeuchi, \& Taylor, 2005), changes in job roles (Robinson, Kraatz, \& Rousseau, 1994; Robinson \& Rousseau, 1994; Robinson, 1996), organizational skepticism (Johnson \& O’leary-Kelly, 2003), and deviant behaviours (Bordia, Restubog, \& Tang, 2008). Consequently, employees who perceive breaches in their psychological contracts with their employers tend to be more skeptical, exhibit greater levels of deviant behaviour, show greater resistance to change, and have elevated levels of perceived injustice in the workplace. One does not need to be a genius to recognize that employees who feel this way are highly likely to leave the organization as a result. Given all of this, I think we can agree that there is significant data showing that psychological contracts are very "real," indeed.

The second question is a bit more challenging. After all, how can we categorize the various types of psychological contracts? Cullinane and Dundon (2006) note that the wide range of psychological variables that this construct has been applied to have made it something of an "analytical nightmare" from a research standpoint. For example, authors have variously conceptualized psychological contracts in relation to things like expectations, promises, exchanges, mutuality, and reciprocity, among others. In this chapter, we will conceive of psychological contracts as proposed by Chiuzi (2014): 
The work psychological contracts are a set of mutual obligations between employer and employees. It is a subjective, dynamic, and mostly implied phenomenon present in the professional environment. The psychological contract is based on reciprocity between the parties, and established by the future intent of actions, attitudes, and behaviours. (pp. 32-33)

This model, including the proposed dynamics, will be explored in the next section. However, before proceeding, a quick recap is in order: we are proposing the psychological contract as a viable and modern alternative to employee management that fosters stronger employment relationships. In addition, it is also important to remember that psychological contracts are phenomena that are most effectively interpreted from a psychosocial perspective.

\section{The new model}

This model was proposed by Chiuzi (2014) after an extensive four-year study of managers and their teams. The participants were from different organizations in distinct sectors (manufacturing, services, and public and private organizations). The proposed model is considered an improvement of Rousseau's theory (1995) and is strongly aligned with Guest's $(2002,2004,2008)$ also Conway \& Briner's $(2002,2005)$ ideas.

Psychological contracts are forged through two central processes: formation and change. The act of "figuring out the clauses" - that is, how one casts and changes these clauses over time-will take place in both of these central processes (Shalk \& Roe, 2007). The proposed model is visually depicted in Figure 1, which is followed by a detailed explanation of the model's underlying dynamics.

The model is based on four critical premises:

a. It works in editions and re-editions of its contents.

b. Reciprocity (Gouldner, 1960) plays a critical role in both its homomorphic and heteromorphic forms.

c. Change is a constant, hence the proposed dynamics.

d. As a psychosocial phenomenon, psychological contracts are dependent on both intrinsic and extrinsic contingencies. 


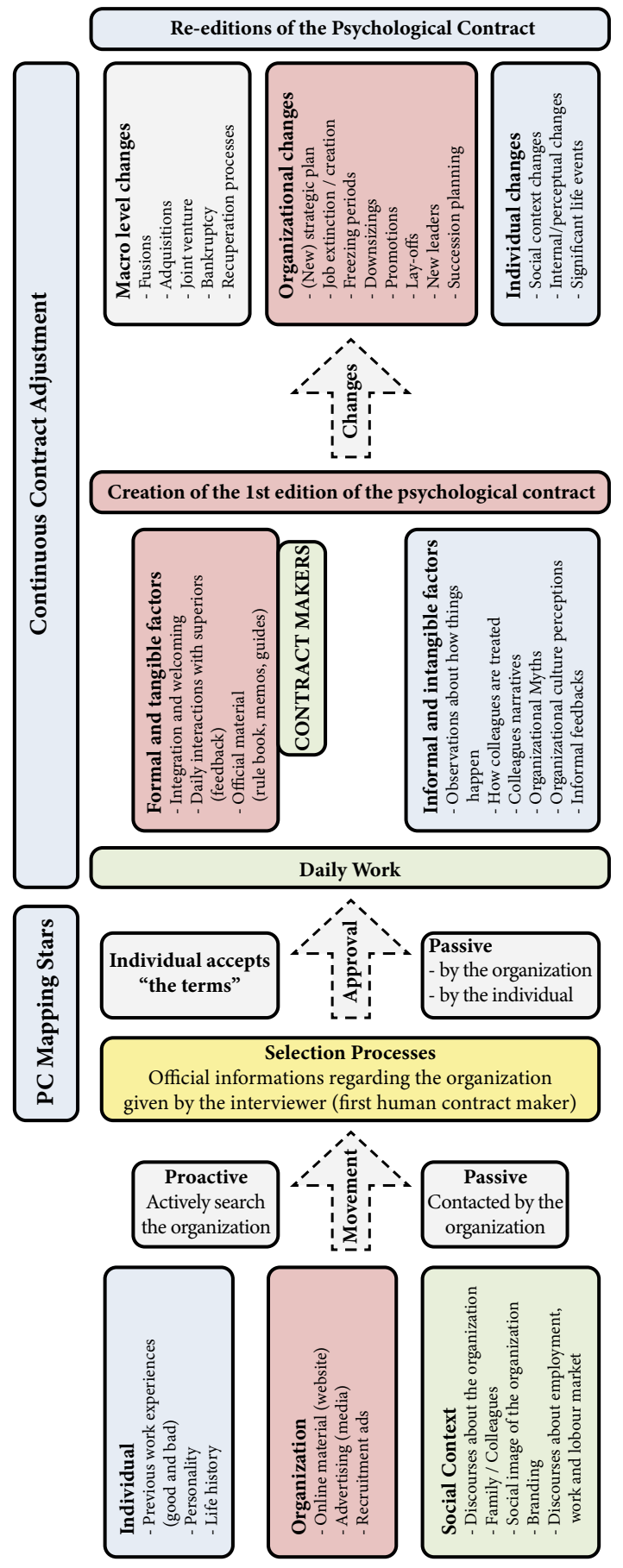

Psychological Contract Formation $1^{\text {st }}$ Process 


\section{The History of John Smith}

In order to help us understand the model, let's consider the case of John Smith (not his real name), who was one of the participants in my Ph.D. research. John is a 37year old engineer and is married with one child. He came from humble origins and was the first person in his family to get a university degree. His father was a bus driver and his mother was a housewife. When I interviewed John, his current job title was Senior Manager, Compliance, with a steel manufacturer. I will call this company \#Steeler. This was his third job experience. Prior to working at \#Steeler, John spent six years as a total quality engineer, and before that he worked as an intern at a bank.

In reflecting on his decision to quit his old job and apply for his current one, John emphasized how much he appreciated \#Steeler's brand value, how difficult it was to find a good job in the tight job market of 2011, and how much he believed he deserved a better position due to his qualifications and expertise. He had just finished a post-graduate degree, as well as his TQM (Total Quality Management) certification. He had thoroughly considered the risks and rewards of this career transition with his wife, and they decided that the raise in salary was worth the extra forty minutes that would be added to John's daily commute. It is also worth noting that John was hired as a junior manager in the total quality management department, not compliance, but we'll get to this shortly.

John "knew" that \#Steeler had a culture of promoting from within and that they were shifting towards a participative and collaborative management style, which he learned from reviewing their website. \#Steeler's bonus policy was also quite attractive for young managers, plus the company offered numerous incentives and allowances for employees to get certain qualifications or to pursue professional development opportunities. John was enthusiastic about these incentive programs, as they offered him the perfect opportunity to start his MBA. According to John, he believed he and \#Steeler would be a good fit, as the company signaled many desirable traits; "It was just a good fit," he told me with a smile on his face.

Now that we've gotten to know John, let's return to the model for a moment. As John's story shows, the psychological contract is formed before the official hiring process even begins (Rousseau, 2001; Svensson \& Wolvén, 2010). For a prospective employee, the psychological contract begins form as a result of reading the job posting, talking to people who have worked for that company, as well as from all other pieces of information that are collected from legitimate sources (O'Leary \& Schenk, 2000).

When forming the psychological contract, a set of intrinsic and extrinsic factors come into play. On the psychological/individual side, factors such as personality (Raja, 
Johns \& Ntalianis, 2004), past work experiences, and life history play an important role in shaping the individual's perception of their obligations to, and expectations of, their future employer. On the extrinsic side, prospective employees will be affected by direct organizational messages and the broader social context concerning the organization. When browsing an organization's website, for instance, elements such as mission and vision statements, shareholder reports, corporate social responsibility advertisements, and the job posting itself (recruitment ad) can all shape how a prospective applicant views the organization and their expectations of it.

On the other hand, broadly speaking, the organization's social context also influences the formation of the psychological contract. Some of the social features that exert a particular influence in this respect include: the company's brand power, discourses about the company, what one's family and friends think about the company, media releases, and even current narratives about trends in the job market. These features are what Rousseau (1995) calls "social cues," and they are closely interrelated to secondary factors such as gender, age, current compensation, and educational level (Guest, 2004). Moreover, the predispositions of both the individual and the organization play a significant role in defining each party's perception of the rights and duties that will be tied into the contract (Roheling, 1997).

This combination of psychological and social factors allows the individual to form the "first draft" of the psychological contract. While this draft will become the lens that filters the individual's information seeking and cognitive processing activities, it will continue to be modified in response to their daily experiences at work. Another way to think of this first draft is as a mental list of what the individual expects of the employer and what they perceive their obligations to be within the context of the exchange that is about to happen. Imagine you can see John's thought process. Perhaps his first draft might sound something like this: "okay, this is what I can offer \#Steeler: my experience, my qualifications, my willingness to increase my commute, and my strong work ethic. In return, I expect good career prospects with lots of opportunities for advancement and professional development, some participation in the decision-making process, and a positive work environment."

Speaking of John, let's get back to him. After reading the job posting, John did some research on \#Steeler and talked to friends and family about both the company and the prospects of making a career change. After all of this, he made the decision to apply for the vacant junior total quality manager position. After an initial round of candidate screening, John was selected for the final round of interviews. The first interview was with the senior manager of human resources. John told me that it was a friendly interview and that, after going through all of the job's technical aspects, the 
discussion mainly focused on the company's workplace culture and the challenges associated with the position. The second interview was with his soon-to-be boss. John perceived him as an easy-going person, with an exciting outlook of the business and an intriguing vision for the TQ department. His first impressions were positive, and he remembered feeling excited to become a part of \#Steeler.

Like John, thousands of candidates go through the same process. Usually, they are either poached from other companies, or, like in John's case, they have decided that it's time to move on and are actively searching for a new job. It is precisely during the selection process that an applicant's first draft will be assessed against the concrete information provided by the first human contract maker-the interviewer. From the organization's end of things, the contract maker could be the HR department, the hiring manager, or even an external consultant (Rousseau, 1994). If the candidate likes what they see but the organization doesn't, the outcome is a rejection. If the organization believes the candidate is a good fit but the candidate doesn't feel the same after scanning their first draft again, it again ends with rejection. However, if the candidate believes the employer will meet most of their expectations, and if the organization believes that the candidate is a good fit, then things move forward. This was the case with John.

\section{Transformations and adjustments in the psychological contract}

John's first day was filled with the usual activities: reviewing orientation packages, watching greeting videos, trying to absorb information about policies and procedures, doing a meet and greet with his new colleagues, and finally having lunch with his new team. Over his first few weeks, John would be wholly occupied by his new job, attending meetings, talking to people, familiarizing himself with the department's needs, and having a lot of one-on-one conversations with his superiors and his team members. According to John, some things were expected whereas others were a little different than he thought they would be - "But this is normal in every company," said John.

It is virtually impossible to anticipate the full spectrum of expectations and obligations in any employment relationship. Nonetheless, some change is to be expected and tolerated, and the intensity of these expected changes will dictate the individual's behaviour. Rousseau $(1995,1996)$ refers to these changes as "contract drifts." In contract drifts, change is rooted in factors such as age and personality, as well as minor changes, known as contractual shifts, which do not disrupt the individual's core beliefs. The most severe type of change is called "transformation," which is usually the result of a breach of the psychological contract. However, we each have a different 
change threshold - that is, how much change we will find acceptable—and this boundary is very difficult to define (Guest, 2004).

John's first weeks are crucial, as they mark the beginning of a series of continual adjustments to his psychological contract with the company. After his first few weeks, John will have been exposed to the official contract makers: memos, formal feedback from his superiors and peers, guides, onboarding training, and many other organization-controlled narratives that will tell John what, in fact, he should and should not expect from this relationship. At the same time, the informal organization conveys powerful cues to John. Some examples of this include the way John's colleagues are treated, "epic" stories about disgruntled employees, and myths surrounding the CEO; in short, the way things happen on a daily basis is a by-product of the informal organization.

These formal and informal contract makers provide John with the information he needs to fine tune his expectations until he has reached a relatively stable set of understandings. This set of understandings will make up the first edition of his psychological contract with \#Steeler. In order to better understand this process, we can use the example of a written legal contract. Imagine that John has the contract in one hand and a red marker in the other. As John's first few weeks pass, he makes a check mark next to the clauses that are "actually happening" and strikes out those that are "not happening" (and most likely will not happen).

According to Shore and Tetrick (1994), the psychological contract operates as a buffer for insecurities and compensates for the fact that it is impossible to draft a formal contract covering all aspects of employment. Furthermore, psychological contracts mould behaviours within the company and carry information regarding influences within the organizational setting (Thomas \& Anderson, 1998). Therefore, it is safe to say that workplace psychological contracts are formed during the day-to-day operations and settings of a given organization (Chiuzi, 2012). As such, an employee's psychological contract must be viewed as being the product of a long-term construction process.

Although this "check and scratch" process takes place over months of day-to-day experience in the workplace, it tends to occur with greater intensity during the first few months on the job. About this process, John said:

"It's like coming to work expecting a novelty. You learn something new every day, and you try to manage all the wealth of information with grace. But some other issues, like my ambition of starting my MBA for example, I knew I should keep with myself and 
wait for the right time to bring it up. This is not something you will talk about in the first months in a job".

When asked whether he was disillusioned about any aspects of the company, John said that \#Steeler was like any other company and that it had its positive and negative characteristics. However, John did note that he was somewhat bothered by the "speed of things" at \#Steeler.

\section{The change}

John was full of ideas; he saw numerous opportunities to step up the game in the TQM Department, from better KPIs to revamping the IT system communication with the ERP. He was energetic and, most importantly, he knows how to make his ideas a reality.

Unfortunately, there was one problem: every time John would bring new ideas to his boss, it felt like the idea would invariable be "put on hold." John would take the time to prepare and present his case for the change, skillfully using data to show how his idea would improve the business; however, despite his efforts, nothing ever seemed to move forward. John was perplexed: "After all, do they want me to do this or not?" After being with \#Steeler for six months, he decided to have a candid conversation with his superiors. He called a meeting with his senior manager, the director, and the VP of operations (his boss's boss). John opened by politely explaining why he'd called the meeting: "The reason I called you here today is to discuss my performance and your view for the TQM Department. I know that the Company has a history of 'taking the time' before implementing some changes, however I feel like this time is becoming too much time." Before John could continue his open-hearted statement, the VP interrupted him.

John froze and expected a harsh response, bracing himself for a bumpy ride. However, the VP's response took a different tone:

"John, you are a good guy. The reason why things are not moving forward in the TQM Department is that the company is in the middle of a very complicated negotiation with one of our Senior Managers. We had many discussions at the executive level, and we feel that your talents would be better used as a Senior Manager of Compliance."

John was speechless. Before he could say anything, the VP continued:

"We know that this seems abrupt; however, you've been with us for six months and already gave us a lot to think about in terms of new things we should have been looking 
at. Of course, you don't have to give us the answer right away. So, you can think about it and get back to us by the end of the week."

Ultimately, John decided to take the job-after all, it was a promotion from junior to senior manager. Nonetheless, he knew that this "extra money" would come at a cost. Coming from a TQM background, John knew very little about compliance, which meant that he would have to study hard in order to learn the ins and outs of compliance policies, procedures, and the many other elements of the job that would enable him to perform well. In other words, John would not be a shining star in his first months because he would have to figure out how to catch up with the best-in-class with regards to compliance. With the new job (and salary) came a new team, new boss, new stakeholders, and new responsibilities within \#Steeler.

For John, this amendment to his psychological contract was acceptable because he perceived the balance between what he offered and what the organization would provide in return as being fair. In other words, there was a mutual reciprocity between John and \#Steeler. As stated by Schein (1965), workplace psychological contracts are significantly influenced by organizational culture; due to this direct relationship, the clauses must be interpreted from a broader perspective than that of the individual. In John's case, the contract was clearly reciprocal.

Gouldner's theory (1960) states that reciprocal norms can either be heteromorphic or homomorphic. Heteromorphic reciprocity occurs when a good or service is paid back using a different good or service of equal value ("tit-for-tat"). In contrast, homomorphic reciprocity occurs when a good or service is repaid using the exact same good or service ("tat-for-tat") (p. 172). To illustrate, let's say I borrowed a hundred dollars from a friend, and one month later I paid them back with exactly one hundred dollars. This exchange was fair, and it was settled using the same good. Thus, it is a case of homomorphic reciprocity. Now, let's say that after a month I don't have the money to repay my friend, so instead I offer to wash their car and clean their apartment. If they agree and think this is a fair trade, then I have effectively repaid them using a different currency. This would constitute an example of heteromorphic reciprocity.

Since change is inevitable, a psychological contract model should make contingencies for it in its analytical framework. This is particularly important in the business world, as one of the key universal truths in this sphere is that change is a constant. Changes vary in size and duration. Some changes occur on the macro-level, and these changes are extended in length and have high impacts. Examples of such changes include fusions, mergers, and bankruptcies. Other changes are smaller and internal (organizational changes), such as those that occurred in John's case. Other examples 
of smaller or internal-level changes include freezing periods, the development and implementation of new strategies, succession planning, layoffs, and the development of new structures.

As changes take place, employees like John will be constantly required to revisit and revise their psychological contracts with the organization. Some may quit if they perceive the changes as representing a massive breach of their "initial agreement." These employees usually describe the emotions that result from such breaches using terms like "betrayal" (Bligh \& Carsten, 2005). Conversely, other employees will be more accepting and will adjust their contract in response to the new demands and the new reality brought about by the change. Thus, those who stay will revise their psychological contracts to produce an updated "edition": just like a book, outdated chapters or passages will either be removed or re-written, while other, new chapters or passages will be inserted to keep the manuscript up to date.

John's history is like that of many others around the world. In this ever-changing environment, we should concentrate our efforts on finding new perspectives for managing people and creating beneficial forms of employment that can simultaneously accommodate difference and ensure competitiveness and sustainable financial health.

\section{Final considerations and suggestions}

Now that we have discussed what psychological contracts are and how they are formed, I want to make a case for why they matter and why they should be considered a feasible alternative for improving employment relationships. To do so, I will highlight three trends of the future of work and workplaces and their implications regarding the application of the psychological contracts theory for the betterment of employment relationships.

\section{The needs of the new workforce}

A report from PWC (2018) found that only about $60 \%$ of professionals believe they will have a full-time job in the year 2030. Moreover, the report's authors affirm that professionals' resumes will be defined by their specialties rather than the brands of their previous employers. As a consequence, the report predicts that employee levels near to zero will be the norm for the future. This means that organizations will generally consist of a few pivotal people who will use technology and supply chains to meet their business needs.

Similarly, a report from Deloitte (2016) entitled, "The future of the workforce," highlights some of the forces that are transforming the way people work and relate to 
the economic market. In particular, Deloitte (2016) identifies four key forces: demographic upheaval; ever-present and changing digital technology; accelerated rates of change and business-model innovation; and the rise of a new social contract. This last factor is especially significant because it describes a transformational force that has led to the reconstruction of social relationships.

At present, it seems inevitable that most human labour will soon be replaced by machines and artificial intelligence. Regardless, it remains the case that organizations will still rely on human expertise to get things done. Indeed, even if we grant that corporations are moving towards near-zero employment, as stated in the PWC (2018) report, these companies will still need humans to perform some actions. In this forecasted scenario, it is plausible to believe that psychological contracts will focus on transactional elements rather than long-term (or relational) ones. However, this is not a new observation, as many other authors have also noted this potential shift (Rousseau, 1995; Hiltrop, 1996; Guest, 2008; Conway \& Briner, 2005).

As demographics change and the younger workforce gradually takes over, new values and ways of doing business will emerge. In my experience with undergraduate and graduate students, these traits are apparent; for example, a good portion of my students seriously consider starting their own companies, while others are interested in seeking a globalized and flexible career. Although these goals are markedly different, they share a common ground: flexibility. These students don't seem particularly worried about machines taking over or not being able to find work in the future. In fact, in my many conversations with them, I have noticed that they tend to have a positive outlook regarding this new setting, and that they view it as being conducive to their desire of being great.

Whether you are your own boss or if you work for a company, you still have to "negotiate" your work relationships. Therefore, empowering the new workforce with the skill and ability to negotiate this grey area seems like an appealing arrangement.

\section{From "until death do us part" to "let's see how this goes"}

The mindset of the future workforce is clear: rather than long-term careers that are based on mutual respect and loyalty, these new workers prefer fluid relationships and short-term gigs (as a matter of fact, these gigs may be the only option available). I grew up surrounded by traditional Brazilian culture during the 1980s and 1990s, and I can vividly remember my grandparents saying to me "when you jump from branch to branch, no employer wants you." As strange as that advice sounds to me today, it made total sense back then. However, much has changed since then. 
A McKinsey Global Institute Report (2016) reveals that 20 to $30 \%$ of the working-age population in the United States and the EU-15, or up to 162 million individuals, are engaged in some form of independent work. Significantly, this study found that those who pursued independent work by choice (free agents and casual earners) reported greater levels of satisfaction with their work lives than those who do so out of necessity (reluctants and the financially strapped). This finding was consistent across countries, age, income, and education, with satisfaction levels being directly related to choice.

Now, think of yourself growing up as a Generation $\mathrm{Z}$ (or whatever name you want to call people born after the year 2000): you have had the internet your whole life and you are used to speedy things like instant messaging and fast relationships. On top of all that, you likely grew up in a social circle that valued self-employment. Or, if you did go to work for a corporation, your social context likely taught you that things should move fast. That means promotions every year, bonuses, fast-tracking, and many more of the items on your list (or your psychological contract, to be more precise).

Now let's put these elements together. Instead of looking for a "marriage" with some employer (i.e. long-term, loyal, steady and consistent), the new workforce will "date" several employers and look for a good match (i.e. short-term, transactional, exchange-based relations). This change will not only require employers to find creative ways of attracting and managing talent, but it will also signal that jobs, as we know them, have changed.

\section{The speed of job obsolescence}

Companies develop job descriptions in order to enable a number of HR-related tasks, such as determining compensation, conducting performance appraisals, recruitment and selection, succession planning, and initiating legal actions, for example, terminations and workplace investigations (Bellcourt, Singh, Snell, Morris, \& Bohlander, 2017). Essentially, a job description is a guide that outlines all of the criteria that will be used to determine whether the employee is performing well; it is a solid, stable, detailed description of what the occupant should do, and with whom, when, and how they should do it. So, when it comes to fast-paced changes, how long will it be before the job descriptions go extinct?

Ferguson (2013) argues that most companies take longer to find the right applicants because they get stuck on job titles instead of hiring for skills. Well, guess what? Old habits die hard, even in business, and an over-emphasis on job descriptions has led to considerable inefficiency in the hiring process. When all the pieces are put together, 
one thing becomes very clear: the emerging gig economy and the new workforce, combined with fast-paced changes and technological advancements, have all but doomed "jobs" (and job descriptions) to obsolescence, likely sooner than later.

So what is the alternative? In the future, one option that might make more sense would be to focus on a list of skills and "deliverables" rather than a prescription of activities. This shift will provide employers and HR departments across the globe with a fluid, fast, and dynamic way of gathering the resources and personnel that they need to get a particular job done. Moreover, employers and HR departments should find a way of increasing collaboration and cooperation using this complex thread of intangible forces that will define the future of employment. This is the niche of psychological contracts.

In conclusion, there are many factors supporting the business case for psychological contracts as a modern alternative to people management. There is strong evidence that indicates that the traditional bureaucratic model is becoming obsolete, which means that there is a need for a dynamic approach that is capable of coping with the fast-paced business environment. The Chiuzi model (2014) of workplace psychological contracts addresses these dynamics by incorporating workplace changes, both micro and macro, and addressing the manner in which individuals continually amend their psychological contracts.

For fellow researchers, it would be of great interest to see a longitudinal study that uses this model and broadens of some of its categories, specifically those related to change. For fellow practitioners, the psychological contracts framework provides an array of possibilities. Here are a few ways this model could be applied to improve company-employee relations:

- Improving the selection process by addressing elements of the psychological contract in a two-way format. This format will offer candidates more palatable information regarding the company's culture and its ways of doing things, while also providing employers with an opportunity to get a feel for the candidates' perceived obligations and expectations, as well as their career timeline.

- Enhancing onboarding experiences by focusing on each employee ("Spotify" the onboarding process) as opposed to a one-size-fits-all mass orientation that may not focus on critical elements of the psychological contract.

- Using psychological contracts as a source of constant re-negotiation, especially for project-based enterprises.

- Inserting elements of psychological contracts into employee surveys, such as organizational climate and satisfaction surveys, and even in exit interviews. 
- Professionally, using the work psychological contract theory in change management to both measure change readiness and to design actions that will ease the transition process from the current state to the desired one.

Those are broad-stroke examples, and they are meant to be ideas to be considered when discussing the application of this exceptionally complex phenomenon. However, as this chapter has hopefully made clear, the volatility of employment relations has required employees and employers to find new, smarter alternatives that both sides perceive as being effective, feasible, and fair. As a consequence, I believe that psychological contracts offer a mechanism that can ensure this balance is reached.

\section{References}

Akremi, A. E. \& Ameur, S. B. (2005). Rôle de La justice organisationnelle dans Le processus de rupture Du contrat psychologique. LIRHE - Unité mixte de recherche CNRS/UT1. Université des Sciences Sociales. Toulouse / France. http://www.univ-tlse1.fr/LIRHE/ retrieved in 22 of June, 2011.

Argyris, C. (1960). Understanding Organizational Behavior. Dorsey.

Bellcourt, M., Singh, P., Snell, S., Morris, S., G. W. (2017). Managing Human Resources: eighth Canadian Edition. Toronto: Nelson Publishing.

Bligh, M. C. \& Carsten, M. K. (2005). Post-merger psychological contracts: exploring a multiple foci conceptualization. Employee Relations, 27(5), 495-510.

Bordia, P., Restubog, S. L. D. \& Tang, R. L. (2008). When employees strike back: investigating mediating mechanisms between psychological contract breach and workplace deviance. Journal of Applied Psychology, 93(5), 1104-1117.

Chiuzi, R. M. (2014). As dinâmicas de formação e continuidade dos contratos psicológicos de trabalho. Doctoral Thesis, Instituto de Psicologia, University of São Paulo, São Paulo. doi:10.11606/T.47.2014.tde-27112014-104051. http://www.teses.usp.br

Chiuzi, R. M. (2012). Quando os contratos psicológicos de trabalho acontecem: o lugar do cotidiano. In: Malvezzi, S., Orejuela, J. J., Chiuzi, R. M., Vesga, J. J. \& Riascos, W. A. (2012), Gramáticas actuales de La relación hombre-trabajo: propuestas de lectura, (pp. 59-74). Editora Bonaventuriana.

Conway, N. \& Briner, R. B. (2005). Understanding psychological contracts at work: a critical evaluation of theory and research. Oxford University Press.

Conway, N. \& Briner, R. B. (2002). Full-time versus part-time employees: understanding the links between work status, the psychological contract and attitudes. Journal of Vocational Behaviour, 61, 279-301.

Cullinane, N. \& Dundon, T. (2006). The psychological contract: a critical review. International Journal of Management Reviews, 8(2), 113-129. 
Deloitte (2016). The future of the workforce: Critical drivers and challenges. https://www2. deloitte.com/global/en/pages/human-capital/articles/future-of-the-workforce.html. Retrieved in November 2018.

Ferguson, M. (2013). Job titles aren't that important. Harvard Business Review. https://hbr. org/2013/04/dont-filter-job-candidates-by. Retrieved in November 2018.

Gouldner, A. W. (1960). The norm of reciprocity: A preliminary statement. American Sociological Review, 25, 161-178.

Guest, D. (2004). The psychology of the employment relationship: an analysis based on the psychological contract. Applied Psychology, 53, 541-555.

Guest, D. (2004b). Flexible employment contracts, the psychological contract and employee outcomes: an analysis and review of the evidence. International Journal of Management Reviews, 5/6(1), 1-19.

Guest, D. \& Conway, R. (2002). Communicating the psychological contract: an employer perspective. Human Resource Management Journal, 12(2), 22-38.

Guest, D. (1998). Is the psychological contract worth taking seriously? Journal of Organizational Behavior, 19, 649-664.

Hiltrop, J. M. (1996). Managing the changing psychological contract. Employee Relations, 18(1), 36-49.

Hiltrop, J. M. (1995). The changing psychological contract. European Management Journal, 13(3), 286-294.

Johnson, J. L. \& O'Leary-Kelly, A. M. (2003). The effects of psychological contract breach and organizational cynism, not all social Exchange violations are created equal. Journal of Organizational Behavior, 24, 627-647.

Kotter, J. P. (1973). The psychological contract: managing the joining-up process. California Management Review, 15, 91-99.

Levinson, H., Price, C. R., Munden, K. J., Mandl, H. J. \& Solley, C. M. (1962). Men, management and mental health. Harvard University Press.

McKinsey Global Institute (2016). Independent work: choice, necessity, and the gig economy. https://www.mckinsey.com/ /media/McKinsey/Featured\%20Insights/Employment $\% 20$ and $\% 20$ Growth/Independent $\% 20$ work\%20Choice $\% 20$ necessity $\% 20$ and $\% 20$ the \%20gig\%20economy/Independent-Work-Choice-necessity-and-the-gig-economy-Executive-Summary.ashx. Retrieved in November 2018.

PWC (2018). Workforce of the future: The competing forces shaping 2030. https://www.pwc. com/gx/en/services/people-organisation/publications/workforce-of-the-future.html . Retrieved in November 2018.

Raja, U., Johns, G. \& Ntalianis, F. (2004). The impact of personality on psychological contracts. Academy of Management Journal, 47, 350-367.

Robinson, S. L. (1996). Trust and breach of the psychological contract. Administrative Science Quarterly, 41, 574-599. 
Robinson, S. L., Kraatz, M. S. \& Rousseau, D. M. (1994). Changing obligations and the psychological contracts: a longitudinal study. Academy of Management Journal, 37(1), 137 152.

Robinson, S. L. \& Rousseau, D. M. (1994). Violating the psychological contract: not exception but the norm. Journal of Organizational Behavior, 15, 245-259.

Roheling, M. V. (1997). The origins and early development of the psychological contract construct. Journal of Management History, 3(2), 204-217.

Rousseau, D. M. (2001). Schema, promise and mutuality: the building blocks of the psychological contracts. Journal of Occupational and Organizational Psychology, 74, 511-541.

Rousseau, D. M. (1996). Changing the deal while keeping the people. Academy of Management Executive, 10(1), 50-58.

Rousseau, D. M. (1995). Psychological contracts in organizations: understanding written and unwritten agreements. Sage.

Rousseau, D. M. \& Greller, M. M. (1994). Human resource practices: administrative contract makers. Human Resource Management, 33(3), 385-401.

Schein, E. H. (1965). Organizational psychology. Prentice Hall.

Shore, L. M. \& Tetrick, L. E. (1994). The psychological contract as an explanatory framework in employment relationship. In: Cooper, C. L. \& Rousseau, D. M. (1994), Trends in organizational behavior, (pp. 91-109). Wiley \& Sons Ltd.

Thomas, H. D. C. \& Anderson, N. (1998). Changes in newcomer's psychological contracts during organizational socialization: a study of recruits entering the British Army. Journal of Organizational Behavior, 19, 745-767. 



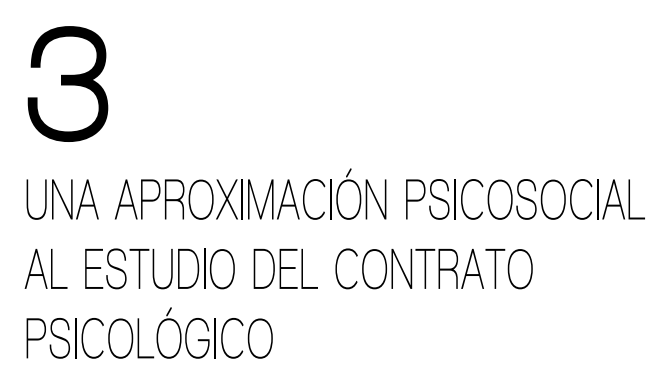

Roberto 0. Díaz-Juarbe*

Universidad de Puerto Rico

Juan Javier Vesga R. ${ }^{\star \star}$

Universidad Católica de Colombia

\section{Introducción}

Este capítulo tiene como objetivo presentar una reflexión teórica sobre el concepto de contrato psicológico visto desde una perspectiva psicosocial. Esta perspectiva defiende la conexión entre lo psicológico y lo social en los estudios organizacionales, y para el presente caso, se ha considerado la teoría de la subjetividad de Fernando González Rey en la discusión. Los autores destacan que la teoría de la subjetividad contribuye al estudio del contrato psicológico y las relaciones del trabajo, ya que ayuda a considerar los procesos simbólicos y emocionales de la acción humana.

Los estudios sobre el contrato psicológico se realizan, predominantemente, desde una perspectiva psicológica (véase Agarwal, 2014). Este acercamiento le da un carácter intrapsíquico al concepto, que se ve representado en su propia definición como percepción, creencia o expectativa individual (Levinson Price, Munden, Mandl \& Solley, 1962; Rousseau, 1995; Schein, 1994; Tena, 2002). Estudiosos del tema como Rousseau y Wade-Benzoni (1995) reconocen que el contrato psicológico se da en relaciones de trabajo caracterizadas por un intercambio entre el individuo y la organización. No obstante, esta apreciación de las relaciones de trabajo mantiene una relación de exterioridad entre el individuo y la organización o, dicho de otra forma, entre lo psicológico y lo social, que da sustento a la propia definición de contrato psicológico.

Los recientes desarrollos teóricos del tema del sujeto y de la subjetividad en el campo psi (p. ej. Elliot, 1992, 2004; Castoriadis, 1998; González Rey, 2002, 2013; Guattari

\footnotetext{
${ }^{*}$ https://orcid.org/0000-0002-7957-6277

${ }^{* *}$ https://orcid.org/0000-0003-2382-5104
} 
\& Rolnik, 2006; Parker, 2015) y su vinculación a los estudios del trabajo y las organizaciones (p. ej. Arnaud, 2012; Díaz-Juarbe, 2012; Fotaki, Long \& Schwartz, 2012; Kenny \& Fotaki, 2014; Komporozos-Athanasiou \& Fotaki, 2015; Soto, 2008; Stecher \& Godoy, 2014; Triantafillou, 2000; Vesga, 2016) son esfuerzos que se proponen superar la dicotomía entre lo psicológico y lo social, resaltando una relación coconstitutiva entre ambos procesos. A este acercamiento a los estudios organizacionales y del trabajo se le ha denominado como perspectiva psicosocial (Kenny \& Fotaki, 2014).

La perspectiva psicosocial engloba diferentes teorías que coinciden en su interés por vincular los procesos simbólico-emocionales, las dinámicas organizacionales y la acción humana (Parker \& Fotaki, 2014). Es desde esta perspectiva que los autores del presente capítulo pretenden revisar el concepto de contrato psicológico con el fin de superar la relación dicotómica entre lo individual y lo socio-organizacional. Específicamente, se proponen hacer la revisión desde la teoría de la subjetividad de González Rey (2002).

\section{La perspectiva psicológica del contrato psicológico}

La conceptualización del contrato psicológico se ha centrado en definirlo principalmente como un fenómeno perceptual de los trabajadores, a partir de la propuesta de Rousseau (1995). Una amplia cantidad de estudios se orientan a estudiarlo desde la perspectiva de estos, a pesar de reconocer que el contrato psicológico se da en relaciones de trabajo caracterizadas por un intercambio entre el trabajador y la organización (Rousseau \& Wade-Benzoni, 1995). La noción de intercambio (o reciprocidad) promueve la idea de que los individuos y las organizaciones comparten la responsabilidad de fomentar una relación positiva (Dick \& Nadin, 2011). Dicho de otra manera, "es un camino bidireccional. Las organizaciones escogen a sus empleados y los individuos eligen entrar en organizaciones específicas. Las organizaciones ofrecen y los individuos negocian incentivos y se desempeñan de acuerdo al sistema de recompensas resultante" (Rousseau \& Wade-Benzoni, 1995, p. 318). No obstante, esta noción de intercambio, que es un término central de la categoría contrato psicológico, ignora el papel que juegan las condiciones estructurales y socioeconómicas en la constitución del contrato psicológico (Dick \& Nadin, 2011), promoviendo una relación de exterioridad entre lo psicológico y lo organizacional.

Lo anterior da paso a que el contrato psicológico sea definido desde una perspectiva psicológica donde es el trabajador quien forma, a través de la identificación, registro e interpretación de la información del estímulo ambiental, un contrato psicológico con la organización. Este fenómeno se ha concebido fundamentalmente como "un modelo mental que la gente usa para enmarcar los eventos tales como promesas, 
aceptación y dependencia" (Rousseau, 1995, p. 27), modelo mental por medio del cual los empleados interpretan y significan sus relaciones de trabajo. Tal como lo ha afirmado esta autora, "los contratos psicológicos existen en el ojo del observador y es en ese nivel (individual) que las creencias en los contratos psicológicos son postuladas y afectan tanto actitudes como comportamiento. La mutualidad no es una condición necesaria" (Rousseau, 1990, p. 391).

El análisis que se ha hecho del contrato psicológico desde una perspectiva psicológica implica lo que puede denominarse una psicologización del mismo, entendiendo que este término "supone, de una parte, una individualización de lo social y, de otra, considerar que el núcleo explicativo [...] [del fenómeno] son procesos psicológicos, entendidos como procesos de una mente individual, intrapersonal y asocial" (Crespo \& Serrano, 2012, p. 35). Esta mirada, al reconocer que el contrato psicológico es simplemente un proceso psicológico de los individuos en el trabajo, deja de lado la comprensión de las condiciones estructurales, socioeconómicas, simbólicas y relacionales de su constitución. No es posible seguir sentando las bases de la conceptualización acerca del contrato psicológico desde una perspectiva psicológica, ya que se parte de la premisa de que los contratos psicológicos se forman en el marco de las dinámicas de las relaciones en contextos de trabajo, lo cual implica que el mismo es una construcción en contextos de la cotidianidad laboral y producto de las relaciones de los sujetos trabajadores con sus entornos de trabajo.

\section{Teorizaciones clásicas sobre las relaciones de trabajo}

Las relaciones de trabajo se construyen a través de diferentes niveles y complejidades en los que se estructuran las dinámicas de trabajo; en tal sentido, varios autores han sugerido clasificaciones como organización formal e informal (Barnard, 1968; Schein, 1994; Spink, 1996) o sistema formal e informal (Petit, 1984), para explicar la manera como se estructuran las dinámicas de las relaciones al interior de las organizaciones.

Desde este punto de vista, las relaciones de trabajo se definen en dos dimensiones. De una parte, se encuentran las interacciones que acontecen entre trabajadores para el desarrollo de las tareas derivadas de la organización formal (Argyris, 1960) o sistema formal (Petit, 1984), en el cumplimiento de los propósitos fundamentales y las responsabilidades propias del cargo que ocupa cada sujeto en una organización, cuyo contenido, en términos de Bauman y May (2007), es funcional, caso en el cual las relaciones son guiadas por el propósito de la tarea más que por aspectos de carácter personal. En esta dimensión se establecen una serie de interacciones entre los trabajadores al interior de una organización, o entre estos y quienes se relacionan con ella desde fuera, como es el caso de clientes, proveedores y representantes de otras 
organizaciones con las cuales se establece contacto para diversos fines asociados al trabajo. Esta dimensión constituye la denominada estructura oficial de la organización (Rentería \& Carvajal, 2006). Las relaciones de trabajo en ella están dirigidas al desarrollo de las actividades propias del cargo o el objeto del contrato laboral, clasificadas en tareas y funciones y articuladas a través de procesos y procedimientos, políticas, normas y reglamentos. Las interacciones que ocurren entre los sujetos en el ámbito de lo formal acontecen en el marco de los referenciales impuestos por las normas establecidas por las autoridades de la organización e institucionalizadas a través de los documentos oficiales de la misma.

De otra parte, las relaciones de trabajo se refieren también a las interacciones que ocurren como producto de vínculos que están asociados a afinidades o diferencias entre los sujetos, a partir de los cuales se establecen interacciones que no corresponden necesariamente al carácter oficial de la organización sino que son relaciones de compañerismo o enemistad que conllevan a la formación de grupos alternos a la estructura oficial, denominados grupos informales o no oficiales (Petit, 1984; Schein, 1994; Rentería \& Carvajal, 2006); sin importar el origen o qué tan positiva o negativa sea la relación, estas interacciones influyen en las actitudes y emociones de los sujetos involucrados (Barnard, 1968).

Las relaciones de trabajo comprenden entonces las interacciones formales e informales de las personas en contextos de trabajo a través de la constitución de colectivos, agrupaciones o divisiones del sistema organizacional, o como lo denomina Rentería (2004), "formas organizativas", ya sean de carácter formal o informal, oficial o no oficial; ellas constituyen núcleos clave de las dinámicas de trabajo, pues es a través de estas agrupaciones que se desarrollan las actividades de trabajo, interacciones sociales y procesos que dan vida a las organizaciones. El punto común de todas ellas, de acuerdo con Petit (1984), es que son grupos conformados por individuos "que se conocen, reaccionan entre sí y están en estado de interdependencia no solo funcional - por el trabajo- sino también psicológica” (p. 24 [cursivas en el original]).

\section{Cambios en las relaciones de trabajo}

Los cambios ocurridos en las últimas cuatro décadas en los mercados laborales han reconfigurado a su vez el contexto laboral, en el cual las relaciones de trabajo han tenido también importantes transformaciones. Este contexto se tipifica hoy a partir de la metáfora de la red. En años recientes, la noción de red como referencia a las estructuras sociales y organizacionales se encuentra en el centro de un elevado y diversificado número de publicaciones teóricas o empíricas de diversas disciplinas, y en la actualidad este término está asociado a la idea de traspaso de fronteras tanto 
de las empresas como de los canales de comunicación y subordinación presentes en las estructuras organizacionales (Boltanski \& Chiapello, 2002). Una red, de acuerdo con Castells (2008),

\begin{abstract}
... es un conjunto de nodos interconectados. Un nodo es el punto en el que una curva se intersecta a sí misma [...]. La tipología definida por las redes determina que la distancia (o intensidad y frecuencia de la interacción) entre dos puntos (o posiciones sociales) sea más corta (o más frecuente, o más intensa) si ambos son nodos de la red que si no pertenecen a la misma. [...] Dentro de una red determinada, los flujos no tienen distancia, o es la misma, entre los nodos. Así pues, la distancia (física, social, económica, política, cultural) para un punto o posición determinados varía entre cero (para cualquier nodo de la misma red) e infinito (para cualquier punto externo de la red) [...].Las redes son estructuras abiertas, capaces de expandirse sin límites, integrando nuevos nodos mientras puedan comunicarse entre sí, es decir, siempre que compartan los mismos códigos de comunicación (por ejemplo, valores o metas de actuación). Una estructura social que se base en las redes es un sistema muy dinámico y abierto, susceptible de innovarse sin amenazar su equilibrio. (pp. 506-507)
\end{abstract}

Esta imagen que describe Castells sobre lo que es una red tipifica el funcionamiento del mundo del trabajo en la actualidad, definido por una "nueva forma de organización social" (Castells, 2008, p. 23) caracterizada por la globalización de las actividades, la flexibilidad, inestabilidad e individualización del trabajo y una cultura de la virtualidad (Castells, 2008), aspectos que indudablemente tienen su consecuente efecto en las relaciones de trabajo. En una economía fundamentada en la red, el espectro de las interconexiones empresariales se amplía de manera indefinida, sin límites, impulsando el uso de estrategias colaborativas entre empresas mediante fusiones, coaliciones y alianzas estratégicas de todo tipo (Vasconcellos \& García, 2010), y configurando una especie de nuevo "contrato social" basado en acuerdos temporales de cooperación entre organizaciones (uniones temporales, clústeres productivos, franquicias, holdings, consorcios, joint ventures, entre otros.) con carácter vinculante entre sus miembros, en el marco de un conjunto más amplio de acuerdos y tratados internacionales entre los países.

En este contexto, las relaciones de trabajo deben ser consideradas más allá del ámbito exclusivo y de los límites de las organizaciones como unidades aisladas, o como lo afirman Rubery, Earnshaw y Marchington (2005), "el crecimiento de las relaciones interorganizacionales incrementa la necesidad de considerar la relación de trabajo más allá del lugar específico de trabajo o la empresa" (p. 65). Las relaciones de trabajo en la actualidad se conciben "como interacción que se da entre actores clave del proceso productivo" (De la Garza, 2009, p. 127), sean estos clientes, contratistas o 
empresas aliadas que configuran redes estratégicas colaborativas en torno a proyectos específicos.

Un concepto clave que define las relaciones de trabajo en la actualidad es el de heterogeneidad. Este aspecto pone de relieve la multiplicidad y variedad en la construcción de vínculos relacionales de los trabajadores con diversos sujetos y organizaciones a través de una diversidad de proyectos productivos, comerciales o de servicios, y "una gran diversificación de los niveles salariales, calificaciones, contenidos del trabajo, condiciones de seguridad, estatus, cargas y formas de comunicación laborales" (De la Garza, 1997, p. 78), por lo que "la formación del paradigma de la red está ligado, de forma muy general, a un creciente interés por las propiedades relacionales (y las ontologías relacionales), en contraposición a las propiedades sustancialmente asignadas a seres que quedarían definidos por ellas" (Boltanski \& Chiapello, 2002, p. 214).

\section{La perspectiva psicosocial de las relaciones de trabajo}

Tradicionalmente, las relaciones de trabajo han sido estudiadas y claramente definidas desde una perspectiva jurídica (Spooner \& Haidar, 2006), reduciéndolas casi exclusivamente a este orden, en el que las partes involucradas establecen una serie de acuerdos mediados por un contrato de trabajo. No obstante, el ejercicio del rol de trabajador por parte de las personas en las organizaciones, independientemente del tipo de contratación, establece además un conjunto de nexos e interacciones entre trabajadores y organizaciones referidos a diversos asuntos del trabajo que sobrepasan el ámbito de lo jurídico o económico y que involucran aspectos tanto psicológicos como sociales.

Estos aspectos están presentes en las dinámicas de trabajo que relacionan a individuos y organizaciones con ocasión de la realización de las actividades del trabajo. No obstante, queda el problema de cómo definir la relación entre ambos aspectos. Desde una perspectiva psicológica, se reconoce que en las dinámicas de trabajo hay aspectos psicológicos importantes tales como percepciones, actitudes, producción de significados y sentidos, atribuciones o procesos identitarios por parte de los individuos que participan de la acción de trabajar. Sin embargo, deja a un lado aspectos sociales tales como los procesos relacionales entre los individuos y el contexto, espacios simbólicos donde se construyen procesos comunicativos, así como la formación de vínculos, negociaciones y acuerdos.

Superar la mirada psicologista del contrato psicológico no debe llevar a posturas sociologistas sobre las relaciones de trabajo y el contrato psicológico, privilegiando lo social sobre lo psicológico. Antes bien, debe procurarse una perspectiva psicosocial 
que supere la dualidad conformada por dos elementos aislados, individuo y colectivo social, y que aluda a una dimensión integrada e integradora, un punto de convergencia entre la persona y los contextos en los cuales participa como sujeto de la acción. Lo psicosocial no se refiere a una dualidad, más bien, es, parafraseando a Schütz (1979), un mundo intersubjetivo compartido con los otros, un mundo común a todos que implica un relacionamiento mutuo. El término "relaciones de trabajo" describe el conjunto de interconexiones e interacciones de índole psicosocial que existen entre personas y entre estas y las organizaciones de las que hacen parte con ocasión de la realización de actividades de trabajo, entendiendo aquí el "trabajo como una actividad económico-productiva" (Rentería, 2008, p. 69).

\section{Un acercamiento psicosocial al concepto de contrato psicológico}

Como puede apreciarse a partir de todo lo expresado anteriormente, las relaciones de trabajo son un proceso muy complejo por la dinámica individuo-organización, y es precisamente esta complejidad la dificultad principal para el estudio del contrato psicológico. Estudios organizacionales y del trabajo han comenzado a incorporar el tema del sujeto y la subjetividad por su potencial para comprender las dinámicas organizaciones de manera crítica. De acuerdo con Parker y Fotaki (2014), los estudios psicosociales giran en torno al problema de una subjetividad enraizada en contextos socioculturales. Este acercamiento psicosocial coloca al sujeto y a la sociedad (o a la organización como un tipo de entorno social único) en una relación recursiva donde "los productos y los efectos son, al mismo tiempo, causas y productores de aquello que los produce" (Morin, 2007, p. 106).

Sin embargo, lo psicosocial no constituye una perspectiva unificada. Son diferentes las perspectivas que han realizado diversas aportaciones conceptuales a los estudios organizacionales y del trabajo, siendo la mayoría perspectivas psicoanalíticas (véase Kenny \& Fotaki, 2014). La perspectiva histórico-cultural, que tiene su fundamento en la obra seminal del psicólogo bielorruso L. S. Vygotski, es una de las concepciones que recientemente ha sido aplicada a problemas organizacionales y del trabajo, específicamente a través de la teoría de la subjetividad elaborada por González Rey (2002). Investigadores como Díaz-Juarbe (2012) y Vesga (2016) han incorporado a sus estudios organizacionales y del trabajo conceptos de la teoría de la subjetividad como sujeto, subjetividad, sentido subjetivo y configuración subjetiva. En los siguientes apartados pretendemos revisar el concepto de contrato psicológico haciendo uso de las ideas centrales de la teoría de la subjetividad de González Rey, proponiendo así una comprensión psicosocial del término. 


\section{Sujeto y subjetividad: sobre las ideas centrales de la teoría de la subjetividad}

La teoría de la subjetividad se apoya en una perspectiva histórico-cultural que comprende el desarrollo psicológico del ser humano como un proceso complejo que tiene sus orígenes en la cultura, sin reducir lo psicológico a un mero producto cultural (Arias Beatón, 2005). La subjetividad, desde esta perspectiva, constituye "una opción ontológica para el desarrollo de la psicología que destaca un nivel cualitativamente diferenciado del psiquismo humano en las condiciones de la cultura" (González Rey, 2013, p. 39). De acuerdo con González Rey (2013), la subjetividad no constituye un epifenómeno de las prácticas culturales sino una producción sobre lo vivido. Este carácter generador de la subjetividad permite romper con una concepción estática de la psique humana y con aquellos intentos de reducirla a prácticas culturales (e.g. prácticas discursivas). Se entiende que la subjetividad es producto y productora de las prácticas culturales sobre las que se organiza la vida social.

Esta concepción de la subjetividad concuerda con la perspectiva psicosocial que defienden Parker y Fotaki (2014), y no solo permite romper con la tendencia de asociar el término con lo intrapsíquico y lo individual sino que, al articular lo individual y lo social en una relación dialéctica-recursiva, permite comprender que la subjetividad es simultáneamente individual y social (Mitjáns Martínez, 2008). Definida por González Rey (1999) como "la organización de los procesos de sentido y significado que aparecen y se configuran de diferentes formas en el sujeto y en la personalidad, así como en los diferentes espacios sociales en los que el sujeto actúa” (p. 108), la subjetividad es un sistema que integra los procesos simbólicos y emocionales que se organizan tanto en el plano individual como en el de las relaciones sociales.

La subjetividad individual "representa los procesos y formas de organización subjetiva de los individuos concretos. En ella aparece constituida la historia única de cada uno de los individuos" (González Rey, 2002, p. 212). De acuerdo con el autor, la subjetividad individual expresa, por un lado, la organización subjetiva de todas las experiencias del sujeto y, por otro lado, los procesos singulares de subjetivación relacionados con la experiencia concreta del sujeto. Estos dos momentos, que son mutuamente constituyentes de la subjetividad individual, son la personalidad y el sujeto.

Para González Rey (2002) la personalidad es un sistema subjetivo autoorganizado de la experiencia histórica del individuo. En ella aparecen organizadas subjetivamente todas las experiencias del sujeto. De acuerdo con el autor, la personalidad no está determinada por fuerzas externas, sino que "tiene una capacidad generativa que se expresa ante la acción de cualquier fuerza externa, la que dejará su marca sobre el 
sistema en los términos del sistema, o sea, en forma de sentido subjetivo" (González Rey, 2002, p. 224). Esto implica que el sentido que toma una experiencia va a estar mediado por las configuraciones subjetivas de la personalidad y no por fuerzas externas como el ambiente, las interacciones, las relaciones de trabajo, entre otras. No obstante, el sentido que emerge de las configuraciones subjetivas de la personalidad entra en tensión con la capacidad del individuo para desarrollar procesos singulares de subjetivación sobre sus experiencias; es a esta capacidad que González Rey (2013) conceptualiza como sujeto.

El sujeto, a través de sus decisiones, construcciones e ideas, produce de manera consciente sentidos subjetivos que entran en tensión y contradicción con las configuraciones subjetivas de la personalidad, que no son conscientes. Representa, así, una zona de tensión entre la historia personal y las producciones conscientes de la persona (González Rey, 2013). Además, la categoría sujeto busca "destacar la capacidad de la persona para desarrollar caminos singulares de subjetivación en el curso de sus experiencias, generando tensiones con las normas y situaciones objetivas que aparecen como hegemónicas y rectoras de su acción" (González Rey, 2013, p. 37). Ser sujeto es ocupar un sitio, una posición con respecto al mundo (Morin, 2007). Por tanto, la persona deviene sujeto de su experiencia cuando se posiciona, cuando genera un espacio propio de subjetivación que va más allá de los significados y sentidos que organizan los espacios sociales en que actúa.

Es importante entender que, a la luz de la teoría de la subjetividad aquí presentada, la categoría sujeto no se limita a un sujeto cognitivo que percibe, interpreta el mundo. Para González Rey (2002), la emocionalidad constituye una condición permanente en la definición de sujeto, pues el pensamiento y el lenguaje siempre se expresan desde el estado emocional de quien habla y piensa. Las emociones no están definidas de manera inmediata por los significados ni por las relaciones sociales. Al ser formas de expresión humana que tienen capacidad autogenerativa, estas permiten que las personas tengan diferentes sentidos subjetivos a pesar de compartir el mismo espacio social, significado o sistema de relaciones (González Rey, 2011, 2013).

La subjetividad, según es definida por González Rey (2002, 2008, 2013), no se agota en la subjetividad individual, sino que también aparece como subjetividad social en las producciones subjetivas que configuran los espacios sociales. La subjetividad social es entendida como "un sistema de sentidos subjetivos y configuraciones subjetivas que se instala en los sistemas de relaciones sociales y que se actualiza en los patrones y sentidos subjetivos que caracterizan las relaciones entre personas que comparten un mismo espacio social" (González Rey, 2008, p. 235). De acuerdo con el autor, la subjetividad social no está más allá de las personas, pues la aceptación de la 
dimensión simbólica de los espacios sociales permite comprender que lo social, más que una realidad externa al ser humano, es una construcción propiamente humana. Por consiguiente, "sujeto y subjetividad son dimensiones constitutivas de lo social, son una parte esencial de sus procesos de desarrollo y cambio" (González Rey, 2011, p. 143). Comprender que las tramas simbólicas y emocionales generadas por los sujetos, desde lo relacional, organizan simbólicamente las diferentes actividades que ellos comparten, permite integrar teóricamente lo social y lo individual. Para entender mejor esta relación integradora entre lo social y lo individual, González Rey (2002) propone el sentido subjetivo como unidad básica de la subjetividad.

El sentido subjetivo fue definido por González Rey (2010) como "la relación inseparable entre lo simbólico y lo emocional, donde uno evoca lo otro sin ser su causa" (p. 251). Esa unidad de lo simbólico y lo emocional constituye la unidad fundamental que define el carácter subjetivo de la experiencia humana: "el sentido subjetivo es la forma en que una persona vive subjetivamente su experiencia" (González Rey, 2013, p. 35). Las producciones simbólicas y emocionales están configuradas en las dimensiones histórica y social de las acciones de las personas. Esto significa que el sentido subjetivo expresa tanto el momento actual de un sistema de relaciones sociales como la experiencia histórica de las personas y de los espacios sociales donde interactúan (González Rey, 2008).

Los sentidos subjetivos se organizan en configuraciones subjetivas que representan sistemas que median la experiencia vivida. De esta manera, los sentidos subjetivos no son una internalización de lo vivido, sino una producción subjetiva de la configuración subjetiva de cada persona (González Rey, 1999). En la subjetivación de la experiencia, "el individuo, en su singularidad, es un momento constitutivo esencial de lo social, y simultáneamente, es determinado dentro del proceso social que constituye, el que no se agota en su dimensión singular" (González Rey, 1997, p. 105). Es por ello que la significación de lo social en la producción de sentidos subjetivos radica en la cualidad de las relaciones sociales.

\section{El contrato psicológico y su comprensión como configuración subjetiva}

Como ha quedado expuesto en nuestra discusión, la teoría de la subjetividad permite comprender la relación individuo-organización como una relación dialéctica-recursiva donde la subjetividad es una producción de tipo simbólico-emocional sobre una experiencia vivida. De esta manera, el contrato psicológico aparece en forma de significados y sentidos subjetivos que participan en la organización de la experiencia laboral. Entender que el contrato psicológico se constituye subjetivamente en el 
marco de relaciones de trabajo implica que estas no son dinámicas objetivo-externas a los individuos que participan en ellas, sino que las mismas, como prácticas sociales, son producciones simbólicas de los sujetos.

Las relaciones de trabajo, tanto formales como informales, constituyen significaciones y sentidos que configuran las acciones y comunicaciones entre los trabajadores y entre estos y las instancias de dirección en las organizaciones. Integrar la dimensión simbólica en las dinámicas de trabajo permite entender que los aspectos sociales no son exclusivamente realidades objetivas, sino producciones simbólicas que articulan modos de trabajar. Esto no quiere decir que los significados sociales determinan la constitución del contrato psicológico, sino que es el sujeto, dentro de un sistema de relaciones, quien produce sentidos subjetivos sobre las realidades sociales que son simbólicamente construidas. Por tanto, el contrato psicológico no es la percepción del individuo sobre un medio externo (e.g. la organización), sino una producción simbólica-emocional de un sujeto inserto en diversas tramas sociales, donde el primero es productor de lo segundo y viceversa. Siendo el contrato psicológico un fenómeno psicosocial, el sujeto no actúa en un espacio simbólicamente vacío, ni tampoco es una construcción producto de una relación diádica con algún otro, una relación vis a vis, sino una configuración subjetiva donde intervienen diversos elementos producto de una red de relaciones, historicidades y subjetivaciones de los mundos de la vida laboral en las que el sujeto participa.

En tal sentido, el contrato psicológico, más que ser una variable susceptible de ser observada y medida, debe ser reconceptualizado como una expresión de la subjetividad del trabajador en contextos socio-organizacionales concretos, integrando en su estudio lo individual y lo social. Aunque el sujeto vive diversas experiencias en sus contextos laborales, referidas a las interacciones con distintos actores del sistema organizacional y a las tareas que se le demandan como resultado del ejercicio de su rol como trabajador, el contrato psicológico emerge como una configuración subjetiva que integra procesos simbólicos-emocionales asociados a las vivencias compromisorias en sus relaciones e interacciones laborales, que son significadas y simbolizadas como compromisos implícitos en el marco de la relación de trabajo.

Se concluye que la teoría de la subjetividad de González Rey contribuye a avanzar en la construcción de representaciones más complejas de los diversos procesos y fenómenos del mundo del trabajo: contrato psicológico, relaciones de trabajo, relación empleado-empleador, identidad laboral, motivación, etcétera. Su aportación al estudio del contrato psicológico reside en el énfasis en los procesos simbólico-emocionales que acompañan las acciones de los trabajadores y que afectan, directa e indirectamente, las dinámicas socio-organizacionales. Además, permite superar la 
relación dicotómica entre lo social (organizacional) y lo individual, al proponer que ambas dimensiones expresan una relación complementaria, contradictoria y recursiva por medio de su especificidad simbólico-emocional. De esta manera, el contrato psicológico es comprendido como una interacción singular de significados y sentidos subjetivos que organizan los procesos psicológicos y la acción social de los contextos organizacionales.

\section{Referencias}

Agarwal, P. (2014). The Psychological Contract: A Review Model. Ahmedabad, India: Indian Institute of Management. http://hdl.handle.net/11718/17167

Argyris, C. (1960). Understanding organizational behavior. Dorsey.

Arias Beatón, G. (2005). Un intento de sistematización de los planteamientos esenciales del enfoque histórico cultural en sus inicios. Psicologia: Teoria e Prática, 7(2), 11-48.

Arnaud, G. (2012). The contribution of psychoanalysis to organization studies and management: an overview. Organization Studies, 33(9), 1121-1135. doi: 10.1177/0170840612448153

Barnard, C. (1968). The functions of the executive (30th anniversary ed.). Harvard.

Bauman, Z. \& May, T. (2007). Pensando sociológicamente (2a ed.). BNueva Visión.

Boltanski, L. \& Chiapello, È. (2002). El nuevo espíritu del capitalismo. Akal.

Castells, M. (2004). La era de la información: el poder de la identidad. Siglo XXI.

Castells, M. (2008). La era de la información: economía, sociedad y cultura. Vol. 1: La sociedad red). Siglo XXI.

Castoriadis, C. (1998). The imaginary institution of society. MIT Press.

Crespo, E. \& Serrano, M. A. (2012). La psicologización del trabajo: la desregulación del trabajo y el gobierno de las voluntades. Teoría y crítica de la psicología, 2, 33-48.

De la Garza, E. (1997). Trabajo y mundos de vida. En: E. León \& H. Zemelman, Subjetividad: umbrales del pensamiento social (pp. 75-91). Anthropos.

De la Garza, E. (2009). Hacia un concepto ampliado de trabajo. En J. C. Neffa, E. De La Garza \& L. Muñiz, Trabajo, empleo, calificaciones profesionales, relaciones de trabajo e identidades laborales (pp. 111-140). Clacso.

Díaz-Juarbe, R. O. (2012). Configuraciones subjetivas de la experiencia de precariedad laboral: seis estudios de casos en Puerto Rico (Tesis doctoral). Universidad de Puerto Rico, Recinto de Río Piedras, Grupo de Estudios del Trabajo. https://getupr.weebly.com/tesis-y-disertaciones-upr.html

Dick, P. \& Nadin, S. (2011). Exploiting the exploited: the psychological contract, workplace domination and symbolic violence. Culture and Organization, 17(4), 293-311. doi: $10.1080 / 14759551.2011 .590306$

Elliott, A. (1992). Social theory and psychoanalysis in transition. Blackwell. 
Elliot, A. (2004). Subject to ourselves: an introduction to freud, psychoanalysis, and social theory. Paradigm Publishers.

Fotaki, M., Long, S. \& Schwartz, H. S. (2012). What can psychoanalysis offer organization studies today? taking stock of current developments and thinking about future directions. Organization Studies, 30(9), 1105-1120. doi: 10.1177/0170840612448152

González Rey, F. L. (1997). La subjetividad social y su expresión en la enseñanza. Temas em Psicología, 3, 95-107.

González Rey, F. L. (1999). Personality, subject and human development. the subjective character of human activity. En S. Chaiklin, M. Hedegarrd \& U.J. Jensen (eds.). Activity theory and social practice: cultural-historical approaches (pp. 253-275). Aarhus University Press.

González Rey, F. L. (2002) Sujeto y subjetividad: Una aproximación histórico-cultural. Thomson.

González Rey, F. L. (2007). Investigación cualitativa y subjetividad: Los procesos de construcción de la información. McGraw-Hill

González Rey, F. L. (2008). Subjetividad social, sujeto y representaciones sociales. Diversitas. Perspectivas en Psicología, 4(2), 225-243.

González Rey, F. L. (2010). Las categorías de sentido, sentido personal y sentido subjetivo en una perspectiva histórico-cultural: Un camino hacia una nueva definición de subjetividad. Universitas Psychologica, 9, 241-253.

González Rey, F. L. (2011). El sujeto y la subjetividad en la psicología social. Un enfoque histórico-cultural. Noveduc.

González Rey, F. L. (2013). La subjetividad en una perspectiva cultural-histórica: Avanzando sobre un legado inconcluso. Revista en Ciencias Sociales, 11, 19-42. doi: 10.18046/recs. i11.1565

Guattari, F. \& Rolni, S. (2006). Micropolítica. Cartografías del deseo. Traficantes de Sueños.

Kenny, K. \& Fotaki, M. (eds.). (2014). The psychosocial and organization studies: affect at work. Palgrave Macmillan.

Komporozos-Athanasiou, A. \& Fotaki, M. (2015). A theory of imagination for organization studies using the work of Cornelius Castoriadis. Organization Studies, 36(3), 321-342. doi: $10.1177 / 0170840614559258$

Levinson, H., Price, C., Munden, K., Mandl, H. \& Solley, C. (1962). Men, management, and mental health. Harvard.

Mitjáns Martínez, A. (2008). Subjetividad, complejidad y educación. Psicología para América Latina, 13. http://pepsic.bvsalud.org/scielo.php?script=sci_arttext\&pid=S1870-350X2008000200007

Morin, E. (2007). Introducción al pensamiento complejo. Gedisa.

Parker, I. (2015). Psychology after psychoanalysis: psychosocial studies and beyond. Routledge. 
Parker, I. \& Fotaki, M. (2014). Prologue: Ian Parker on the psychosocial, psychoanalysis and critical psychology, in conversation with Marianna Fotaki. En: K. Kenny \& M. Fotaki (eds.). The psychosocial and organization studies: affect at work (pp. 1-17). Palgrave Macmillan.

Petit, F. (1984). Psicosociología de las organizaciones. Herder.

Rentería, E. (2004). De las intervenciones grupales a las intervenciones sociales. Un ensayo sobre el uso del conocimiento científico en el caso de las intervenciones profesionales. Revista de Estudios Sociales, 18, 37-49.

Rentería, E. (2008). Nuevas realidades organizacionales y del mundo del trabajo: Implicaciones para la construcción de la identidad o del sujeto. Informes Psicológicos, 10, 65-80.

Rentería, E. \& Carvajal, B. (2006). Abordaje psicosocial de la diversidad y papel de formas organizativas en contextos organizacionales instituidos. Psicología desde el Caribe, 17, 149-175.

Rousseau, D. (1990). New hire perceptions of their own and their employer's obligations: A study of psychological contracts. Journal of Organizational Behavior, 11, 389-400.

Rousseau, D. M. (1995). Psychological contracts in organizations: understanding written and unwritten agreements. Sage.

Rousseau, D. M. \& Tijoriwala, S. A. (1998). Assessing psychological contracts: issues, alternatives and measures. Journal of Organizational Behavior, 19, 679-695.

Rousseau, D. M. \& Wade-Benzoni, K. A. (1995). Changing individual-organization attachments: a two-way street. En: A. Howard (ed.). The changing nature of work (pp. 290322). Jossey-Bass.

Rubery, J., Earnshaw, J. \& Marchington, M. (2005). Blurring the boundaries to the employment relationship: from single to multi-employer relationships. En: M. Marchington, D. Grimshaw, J. Rubery \& H. Willmott (eds.). Fragmenting work (pp. 63-87). Oxford.

Schein, E. (1994). Organizational psychology. Prentice-Hall.

Schütz, A. (1979). Fenomenologia e Relações Sociais. Zahar.

Soto, A. (2008). Flexibilidad laboral y subjetividades: Hacia una comprensión psicosocial del empleo contemporáneo. LOM.

Spink, P. (1996). A organização como fenômeno psicossocial: notas para uma redefinição da psicologia do trabalho. Psicologia \& Sociedade, 8(1), 174-192.

Spooner, K. \& Haidar, A. (2006). Defining the Employment Relationship. International Journal of Employment Studies, 14(2), 63-82.

Stecher, A. \& Godoy, L. (eds.) (2014). Transformaciones del trabajo, subjetividad e identidades: Lecturas psicosociales desde Chile y América Latina. RIL Editores.

Tena, G. (2002). El contrato psicológico: relación laboral empresa-trabajador. Revista Acciones e Investigaciones Sociales, 15, 85-107. 
Triantafillou, P. (2000). Work and subjectivity: A review of psychological, sociological and post-structuralist approaches. IKL Working Paper, 39. Copenhagen Business School. http://openarchive.cbs.dk/bitstream/handle/10398/6959/trianta_work.pdf?sequence=1

Vasconcellos, G. \& García, H. (2010). Cooperação e alianças: perspectivas teóricas e suas articulações no contexto do pensamento estratégico. Revista de Administração Contemporânea, 14(4), 722-737.

Vesga, J. J. (2016). El contrato psicológico: Una propuesta de lectura en el marco de las relaciones de trabajo. (Tesis doctoral no publicada). Universidad del Valle. 



\section{4 CONTRATOS PSICOLÓGICOS Y MORALLDAD: EN BUSCA DE RELACIONES DE TRABAJO MÁS JUSTAS}

Sônia Maria Guedes Gondim* Universidad Federal de Bahía, Brasil Mino Correia Rios ${ }^{\star \star}$ Universidad del Estado de Bahía, Brasil

\section{Introducción}

La indagación sobre la naturaleza del actuar humano, especialmente de cuño moral y ético, siempre ocupó la mente de los filósofos y pensadores a lo largo de la historia de la humanidad. En periodos de crisis político-ideológicas, económicas y sociales, en los que los conflictos se vuelven más evidentes en la lucha por recursos escasos, se asiste a un movimiento doble y ambiguo de la sociedad. Por un lado, en una dirección aumentan las polaridades y la intolerancia con la diversidad de formas de pensar, vivir y actuar en el cotidiano de las relaciones sociales, terreno fértil para recrudecer los radicalismos y las demarcaciones identitarias (nosotros versus ellos; amigos versus enemigos; a favor o en contra nuestra). En otra dirección, y como desdoblamiento de esa primera, se genera otro movimiento, fruto de ese pensamiento dicotómico: el de la fragilización de los principios morales y éticos que guían las relaciones humanas. Los medios, como justificación para los fines, flexibilizan la moralidad de forma extrema y ponen en riesgo el sistema de valores que orienta las relaciones de respeto entre los hombres. Las crisis también abren brechas para la adopción de medidas legales que aumentan las opciones de institucionalización de injusticias, particularmente en el ámbito de las relaciones contractuales de trabajo, en las que están implicados dos actores y una desigualdad de poder visible: el empleador y el empleado.

El interés por discutir cuestiones de naturaleza moral, implicando las articulaciones complejas entre conciencia moral y su aplicabilidad a las relaciones contractuales formales o informales entre esos dos actores sociales, fue objeto de análisis de un

${ }^{*}$ https://orcid.org/0000-0003-3482-166X

** https://orcid.org/0000-0003-3288-398X 
ensayo escrito por la primera autora de este capítulo (Gondim, 2020). Apoyada en Jones (1991) y Rest (1986), defendió la tesis de que el actuar moral puede ser perfeccionado al ampliar la conciencia moral del empleador a través de la sensibilidad, atención y motivación moral. El actuar moral resulta de articulaciones complejas entre individuo y sociedad, y se operacionaliza mediante la instancia reflexiva del self moral (Blasi, 1983), que integra cogniciones sociales, afectos y voluntad. EL foco de análisis del ensayo recayó sobre aspectos ético-morales a nivel de las interacciones entre contratantes y contratados, considerando cambios recientes en las leyes de trabajo brasileñas (Brasil, 1943, 2017a, b, c) que debilitaron los vínculos formales de trabajo y disminuyeron brutalmente el foco de los derechos del trabajador. Tal fragilización de las relaciones contractuales de trabajo desplaza de modo aún más visible el foco del ámbito legal hacia el moral, dado que en la negociación entre dos actores sociales que se encuentran en posiciones de poder flagrantemente desiguales, se hace más fácil imponer a quien tiene menos poder condiciones que, aunque sean legales, no son decentes o dignas (Rosenfield \& Pauli, 2012).

Al admitir la existencia de ese desplazamiento del marco legal hacia el moral, el contrato psicológico fue escogido como encuadre conceptual a ser tenido en cuenta para promover relaciones más justas entre trabajadores y empleadores. Como aparece bien descrito en el capítulo de Vesga (2020) de este libro, Argyris (1960) ya había concebido el contrato psicológico en una perspectiva moral, sustentada en la confianza mutua, como un mecanismo para alcanzar el equilibrio en la relación empleador-empleado. Después de un periodo de disminución del interés por el contrato psicológico como eje teórico-empírico para la compresión de las relaciones entre trabajador-empleador (actores sociales concretos) y trabajador-organización (actor social-actor institucional), Rousseau (1989; 1995) realineó el concepto de contrato psicológico, y a pesar de darle un cuño subjetivista e individualista (el contrato psicológico está en la mente del trabajador y no en la relación concreta entre trabajador y empleador), a nuestro entender la autora consiguió retomar el énfasis en la dimensión moral. Su foco pasó a recaer en las promesas, no siempre declaradas y verbalizadas, generadas por la organización o sus representantes formales, que crean un compromiso apoyado en derechos presumidos (cumplimiento de promesas) y deberes (actitudes y comportamientos de reciprocidad sobre las promesas cumplidas).

La moralidad como eje de las relaciones de trabajo supera ese subjetivismo a partir de un nuevo desplazamiento del foco objetivo de las teorías sobre contrato psicológico. En ese caso, saliendo de la unidireccionalidad trabajador-empleador (nivel de comprensión del trabajador), hacia la bidireccionalidad, cuando el contrato psicológico para a ser visto como un regulador de la relación mutua, trabajador-empleador (p. ej. Arnold, 1996; Conway \& Briner, 2005; Guest, 1998). Se abre camino de esta manera al fortalecimiento 
de modelos de contratos psicológicos apoyados en perspectivas teóricas de intercambios sociales, incluyendo la reciprocidad, base para establecer una relación más justa.

No pretendemos retomar todos los puntos contemplados en el ensayo referido, aunque reconocemos que buena parte de la sustentación teórica está apoyada en lo que en él se presenta. El objetivo principal de este capítulo, sin embargo, es traer elementos teórico-conceptuales y empíricos que permitan pensar el establecimiento de relaciones de trabajo más justas mediante la gestión de contratos psicológicos que tengan en cuenta un compromiso doble soportado en intercambios homomórficos (equivalentes en la forma, con contenidos semejantes) y heteromórficos (no equivalentes en forma), que describiremos más adelante. Este modelo de contrato psicológico fundamentó la construcción de una medida para evaluar los contratos psicológicos de profesores de educación superior utilizada en un estudio empírico de nivel de doctorado en el que fueron halladas evidencias de validez (Rios, 2015; Rios \& Gondim, 2017).

Nuestro punto de partida será la contextualización y aclaración de algunos conceptos centrales para alcanzar los objetivos de este capítulo. Posteriormente presentaremos algunas evidencias empíricas para sustentar este tipo de modelo de gestión del contrato psicológico que, aunque haya sido concebido para la población de profesores de educación superior, puede ser transferible fácilmente y adaptado para otros grupos ocupacionales. Desde el punto de vista teórico, esperamos que el capítulo ofrezca insumos para una reflexión crítica y ampliada del contrato psicológico. Al considerar la perspectiva práctica, aspiramos que empleadores y trabajadores visualicen posibilidades de llegar a asumir mayor autonomía en la gestión de los contratos psicológicos, haciendo que las relaciones de trabajo estén fuertemente soportadas en el reconocimiento de que el equilibrio, el medio, es la esencia de la justicia entre los hombres. En una sociedad desigual como la sociedad capitalista en que vivimos, la justicia se vuelve imperativa para contemporizar las grandes diferencias en el acceso a recursos imprescindibles y asegurar una vida digna y decente para todos los seres humanos.

\section{Contextualizando los conceptos: ética y moral en las relaciones de trabajo}

Aunque contemporáneamente los términos ética y moral sean tratados como interrelacionados y a veces como sinónimos, pues ambos sirven de guía de la conducta del hombre en las formas de actuar y de comportarse con los demás, poseen orígenes diversos. En la comprensión de Krüger (2005), es necesario aclarar que la ética (término de origen griego) se presenta como un subcampo de la filosofía con la misión de responder a la pregunta sobre lo que es correcto y lo que no lo es. Adicionalmente, la ética propone una crítica de la moral, analizando sus fundamentos y argumentos. 
La moral (término de origen latino), objeto de análisis de la ética, se manifiesta en el actuar concreto de las personas, y se expresa en costumbres, doctrinas, creencias, leyes y normas jurídicas.

Otra contribución relevante para comprender la interrelación entre los términos ética y moral es presentada por Gontijo (2006), para quien el término ética deriva del sustantivo ethos, que junta los vocablos éthos y êthos. El primero se refiere a un espacio construido y transformado por la acción del hombre con otros hombres (acción social), imprimiendo costumbres y modos de vivir. Êthos, por otro lado, captura la dimensión del carácter personal, visto como producto de un conjunto de disposiciones morales, afectivas, comportamentales e intelectivas.

Siendo presentadas las interconexiones evidentes entre los dos vocablos, en este capítulo haremos uso de forma intercambiada de estos términos. Intentaremos utilizar ética cuando nos refiramos a la conducta humana basada en principios morales, a veces operacionalizados bajo la forma de códigos de conducta ética o normas fuertemente compartidas socialmente. El empleo del término ética en ese sentido está fundado en Hegel (1817/1997), quien diferencia moral de eticidad. La primera se impone por la voluntad humana (conación), una vez que se encuentra en su interior, al tiempo que la eticidad es la concretización de la moralidad (exteriorización), a veces traducidas en códigos de ética.

Asistimos a un interés creciente por cuestiones éticas y morales en el contexto de las relaciones de trabajo, con especial acogida de los modelos desarrollados por Jones (1991) y Rest (1986; 1994) sobre toma de decisiones éticas. Los dos modelos defienden la importancia de la consciencia para la toma de decisión que implica la moral. En el modelo de Rest, cuando la consciencia reconoce un problema o situación en el trabajo como de naturaleza moral, hace activar valores éticos que estimulan el juicio moral, llevando al individuo a una intención de actuar moralmente. No se presume que haya un efecto directo sobre la acción, sino un efecto probable sobre la acción. El modelo de Jones (1991), que se deriva del de Rest, enfatiza aún más en la importancia de que la situación sea interpretada como de naturaleza moral. De esta forma, la motivación para el juicio y la acción moral no dependen apenas de los atributos del agente (por ejemplo, la virtud, como sugiere la perspectiva de Aristóteles), sino del tipo de situación. Para Jones (1991), una situación se volvería potencialmente activadora de la consciencia moral a partir de los siguientes criterios: 1) evaluar los daños y los beneficios causados (fuerza de las consecuencias); 2) grado de concordancia sobre lo que sería una acción buena o mala (grado de consenso); 3) probabilidad de que la acción cause el efecto esperado (potencial de la relación acción-efecto); 4) intervalo 
de tiempo entre el presente y la consecuencia del acto moral (inmediatez temporal); 5) adherencia entre los sentimientos del agente moral y los de la víctima de la acción (fuerza de la identificación afectiva); y 6) número de personas afectadas por la acción (amplitud del efecto de la acción) (Gondim, 2020).

El modelo referido destaca, de esa forma, diversas perspectivas de comprensión de la activación del juicio moral con posibles impactos en la actuación moral. En lo que podemos derivar de Skorupsdki (2002), algunos criterios de la situación señalados en el párrafo anterior estarían apoyados en abordajes instrumentalistas o utilitaristas (p. ej. James Mill, Jeremy Bentham, John Stuart Mill). En el sentido clásico del utilitarismo, el bienestar individual (asociado a los beneficios obtenidos) es entendido como un valor intrínseco. Sin embargo, el término puede asumir un sentido genérico, en el que se reconoce la existencia de diferencias individuales en competencia, lo que hace pensar que la acción moral debería estar soportada en el principio de la promoción del mejor bienestar para la mayoría de las personas. Uno de los criterios enumerados por Jones, el de la identificación afectiva, abre las puertas al reconocimiento de que la empatía y la simpatía, en el sentido dado por Adam Smith (1759/2002), podrían ayudar a comprender lo que lleva a las personas a actuar moralmente para con los otros.

Smith afirmó que los seres humanos nacen con la capacidad simpatética, la de imaginar e interpretar la situación en la que los otros se encuentran, pudiendo evaluar entonces si los sentimientos activados serían apropiados a la situación. Se distancia del sentido de la simpatía por la actividad despertada por la otra persona, como aparece descrito en algunos diccionarios. La simpatía en Smith está basada en la interpretación de la situación en que se encuentra la persona. Es a partir de esa situación que un observador externo evalúa si los sentimientos son apropiados, imaginándose estar en una situación similar. La desaprobación, al evaluar como inapropiados los sentimientos y las emociones expresados en la situación, sería una evidencia de ausencia de simpatía para con el otro. La diferencia de la simpatía con la empatía, según Smith, reside en la suposición de que mientras la última se revela en la capacidad de sentir y experimentar lo que el otro siente, la primera se traduce en ponerse en el lugar del otro, entender lo que él siente, así como evaluar si ese sentimiento sería apropiado (justificado) para la situación. La simpatía es un acto imaginativo que nos permite juzgar al otro y orientar nuestra conducta para con él. Ese otro, a su vez, también nos observa y juzga. Pero ¿sobre cuáles criterios eso otro nos juzga o juzgamos al otro para definir lo que está correcto o errado? Ese es un aspecto clave que está en la base de varias teorías sobre la moral. La filosofía moral se ocupa de las leyes de la voluntad humana que llevan a las personas a actuar moralmente. 
Hay por lo menos tres perspectivas de entender el origen de la acción moral. La primera, ya citada antes, sería fruto de la voluntad del agente que busca practicar la virtud y alcanzar la excelencia personal, sin vicios; la moral de Aristóteles (1985 [circa 300 a. C.]). La segunda sería derivada de principios normativos deontológicos o cognoscitivos (la moral kantiana, por ejemplo) que funcionarían como máximas que imponen deberes para la práctica de la acción correcta (Kant, 1787/1994). Por último, la acción moral tendría origen en la anticipación de la cualidad de las consecuencias para los demás seres humanos (abordajes utilitaristas e instrumentalistas). Nuestro objetivo aquí no es profundizar esta discusión de la filosofía de la moral, lo que nos esforzamos por hacer en otro texto (Gondim, 2020), sino solamente destacar que la manera como entendemos lo que lleva al hombre a actuar moralmente repercute en la manera como tratamos el tema. Esto es fundamental para comprender de qué modo las relaciones de trabajo pueden ser menos justas, cuándo la legislación que asegura derechos del trabajador se encuentra cada vez más debilitada. La justicia acaba siendo cada vez más dependiente, no del sistema legislativo y jurídico institucionalizado, sino de la consciencia moral de aquel que ocupa el poder como empleador, dado que está autorizado, por una legislación débil, para ejercer un tipo de explotación que solo puede ser frenada por el ente moral (self moral).

Evidencias empíricas a favor de Jones (p. ej. Gino, Schweitzer, Mead \& Ariely, 2011; Reynolds \& Miller, 2015; Tenbrunsel \& Smith-Crowe, 2008; Welsh \& Ordóñez, 2013) demuestran que las estructuras organizacionales formales o informales (p. ej. códigos morales, ambiente competitivo) afectan la consciencia moral, y destacan la importancia de interpretar la situación como de cuño moral para desencadenar la motivación, lo cual generaría impactos positivos en la acción moral. Los estudios también traen evidencias de que la acción moral puede ser no consciente (p. ej. Mazar, Amir \& Ariely, 2008; Welsh \& Ordóñez, 2013), o sea, sin reflexión consciente del actor. Desde nuestro punto de vista, esto permite defender la tesis de que la formación del hábito de ser justo, por la repetición cotidiana de la práctica de la justicia, desarrolla la capacidad de ponerse en el lugar del otro. A través del proceso de socialización moral se aumentan las posibilidades de que la activación moral se vuelva más "automatizada" y "natural", evitando lo que Tenbrunsel y Messick (2004) describen como declive ético (desensibilización respecto a cuestiones éticas y morales). En una sociedad gravemente desigual en términos de acceso a los recursos, el proceso de socialización moral estaría orientado por principios de justicia, como forma de alcanzar un término medio en los intercambios, implicando la calidad (valor) y la cantidad de lo que es intercambiado, lo que puede variar en cuanto a la equivalencia del contenido de lo que es intercambiado. 
Hacer que un comportamiento moral sea automatizado y naturalizado significa hacer del acto moral un hábito. La ventaja es que el hábito le ahorra a la consciencia moral evaluar la naturaleza moral de todas las situaciones cotidianas, liberándola para analizar solamente aquellas situaciones imprevistas, cuya moral no fue incorporada al repertorio comportamental (Gondim, 2020, p. 75).

La práctica de la reciprocidad puede hacerse un hábito en las relaciones sociales, siendo fácilmente transferida para las relaciones contractuales de trabajo. Basándose en Kant, Caygill (2000), afirma que en la justicia conmutativa (del ámbito del derecho privado), un intercambio es justo cuando los productos tienen equivalencia. Este es un desafío para las relaciones contractuales de trabajo en contextos capitalistas, en los que uno tiene el poder de compra de la fuerza de trabajo y el otro la ofrece. Los intercambios previstos en la ley tienden a ser heteromórficos (de naturaleza diferente, salario-fuerza de trabajo), para usar la terminología de Burns (1973). Nada impide que el intercambio heteromórfico sea considerado justo, pero es necesario que haya concordancia con que sea este tipo de intercambio el esperado. Sin embargo, al reconocer que hay expectativas o promesas implícitas o no declaradas en las relaciones de intercambio, heteromórficas y homomórficas, se convierte en un desafío alcanzar el término medio que satisfaga, al menos relativamente, las dos partes. El conflicto moral puede llegar como una consecuencia del reconocimiento de que los intereses individuales de una parte se están sobreponiendo a los intereses de otra parte, desequilibrando fuertemente la balanza (Saltzstein, 1994).

A título de síntesis de esta sección, buscaremos contextualizar la moralidad y la ética, y alertar sobre la fragilización de la legislación que rige los contratos formales de trabajo para proteger los derechos de la parte más débil, que aumenta el riesgo de que las relaciones de trabajo se vuelvan seriamente más injustas. Esto porque la desigualdad flagrante de poder desequilibra las relaciones sociales y exige una fuerte implicación moral de los actores, en especial de aquel que tiene más recursos y puede imponer su voluntad al otro; también afecta el reconocimiento de la existencia del contrato psicológico (Chiuzi, 2012, 2014; Gondim \& Rios, 2015; Guest, 1998, 2004a, 2004b; Malvezzi, 2011; Rios \& Gondim, 2010a, 2010b; Roehling, 1997; Rousseau, $1995,2001)$, que no se confunde con el contrato formal legislado; debemos de admitir que ese contrato psicológico, que regula desde el punto de vista afectivo y moral las relaciones entre empleador y empleado, puede ser gerenciado mejor por el trabajador y por el empleador, lo que hace posible vislumbrar intercambios sociales con bases menor injustas. 


\section{De la multidimensionalidad a la construcción y reconstrucción del vínculo: el contrato psicológico desde la base de los intercambios sociales y de la reciprocidad}

De acuerdo con Vesga (2020), cinco periodos marcan la evolución del concepto de contrato psicológico. El primero de ellos se sitúa entre las décadas de los sesenta y los setenta con los trabajos de Argyris (1960), Levinson, Price, Munden, Madl y Solley (1962), y posteriormente Schein (1965). La trayectoria del concepto está marcada por el cambio de objeto foco del contrato. En Argyris se apoyaba en la relación de confianza entre jefe y empleado, en Levinson et ál. (1962) recayó sobre la reciprocidad interpersonal y otros aspectos intangibles de las relaciones contractuales, y en Schein (1965) sobrepasó el foco objetal concreto y se transfirió a un nivel abstracto de relación del trabajador con la organización, lo que provocó una ampliación del concepto que hizo imprecisa su demarcación.

El segundo periodo, entre los años setenta y ochenta, está marcado por la reducción del interés general por el abordaje del concepto, que adquiere de nuevo su vigor a partir de la publicación de los primeros trabajos de Rousseau (1995), quien inauguró un tercer periodo que recuperó la dimensión subjetiva y moral, conforme referimos antes, y el énfasis en la promesa percibida. En los periodos subsecuentes creció el posicionamiento crítico con relación a la teorización sobre contrato psicológico. Se critican tres aspectos; 1) el foco en la perspectiva del individuo, aunque el contrato implique la relación entre dos partes (Conway \& Briner, 2005; Cullinane \& Dundon, 2006; Shore \& Barksdale, 1998; Guest, 1998); 2) la indefinición de quién es el objeto del contrato, dado que la organización es una abstracción con diversos actores que la representan en varios niveles (Guest, 1998); y 3) la naturaleza y los tipos de intercambios implicados en la relación (Janssens, Sels \& Van Den Brande, 2003; Sels, Janssens \& Van Den Brande, 2004; Shore \& Barksdale, 1998; Robinson et ál. 1994).

Estos periodos que marcan la evolución del concepto de contrato psicológico estuvieron acompañados de diversas concepciones sobre cuáles serían las bases y en qué términos los contratos psicológicos estarían construidos. Una de las más importantes tipologías de contratos psicológicos es la de Rousseau (1995), que lo analizó a la luz de dos dimensiones: 1) claridad de los términos (específicos e inespecíficos); y 2) la duración del contrato. La combinación de las dos dimensiones podría llevar a cuatro tipos de contratos psicológicos: transaccional (términos específicos de corta duración), transicional (términos inespecíficos y de corta duración), balanceado (términos específicos y de larga duración) y relacional (términos inespecíficos y de larga duración). 
El modelo de Shore y Barksdale (1998) se presenta como consecuencia de la crítica al modelo de Rousseau. El contrato se sustentaría en la combinación de dos dimensiones de obligaciones: la del empleado para con el empleador y la del empleador para con el empleado. Esto permitió operacionalizar el contrato psicológico implicando dos partes que establecen los intercambios. Claramente hubo un avance en la teorización del constructo, si bien no estuvo acompañado por la forma de medirlo, dado que el trabajador seguía siendo la única fuente de recolección de información para el diagnóstico de los términos y del estado del contrato psicológico. Sin embargo, una ganancia importante fue que los contratos psicológicos pasaron a ser clasificados en términos de obligaciones mutuamente elevadas (empleador y empleado), mutuamente bajas (empleador y empleado), elevada solamente para el empleado u elevada solamente para el empleador. La suposición de un juego de fuerzas que estaría o no equilibrado fue siendo incorporada a los modelos de contratos psicológicos, lo que los volvería más gerenciables.

Otro modelo multidimensional fue propuesto y probado inicialmente por Janssens et ál. (2003) y posteriormente por Sels et ál. (2004). Ese modelo aumentó la complejidad de la compresión del contrato psicológico, fruto del arreglo entre seis dimensiones: tangibilidad (especificidad de los términos del contrato), alcance (aspectos personales o profesionales), estabilidad (aceptación de cambios en los términos del intercambio sin que implique renegociación), estructura temporal (duración de la relación de intercambios), simetría del intercambio (tolerancia de las diferencias en los intercambios entre niveles distintos de la organización), y nivel de regulación del contrato (individual, grupal o colectivo, alcanzando a pocos o a muchos segmentos de trabajadores). Aunque algunas de esas dimensiones se confundan, como las dos últimas, fueron definidas con base en una diversidad de aspectos, desde las características del contrato y variables socioeconómicas, hasta las prácticas de gestión de personas (Sels et ál., 2004). El supuesto del modelo es que esas dimensiones combinadas definirían perfiles de contratos psicológicos diferenciados que oscilarían a lo largo del tiempo debido a cambios a nivel del individuo, de las políticas de gestión de las organizaciones y de las contingencias externas.

$\mathrm{Si}$, por un lado los modelos de contrato psicológico eran concebidos bajo la forma de tipología, sirviendo de herramienta de diagnóstico para la toma de decisiones en gestión de personas, otras discusiones avanzaron en dirección de la comprensión del contrato psicológico como un proceso de construcción y reconstrucción de sentido del vínculo organizacional o con el trabajo, aprehendido de mejor manera por metodologías cualitativas y narrativas individuales de los trabajadores (Conway \& Briner, 2005, Malvezzi, 2011; Rousseau, 2005). Alineados con ese tipo de compresión, hubo un nuevo abordaje de los conceptos de intercambios sociales (Burns, 1973) y 
de reciprocidad como aspectos claves en la concepción del contrato psicológico (p. ej., Chiuzi, 2014). En la perspectiva de Homans (1958, 1962, 1974), existen dos tipos de intercambios: materiales e inmateriales (simbólicos). La teoría de los intercambios sociales pone la dinámica de las interacciones entre los individuos en el análisis de la acción social. La interacción, para Homans (1962), es un proceso en el cual la acción de un hombre genera otra acción en otro hombre con impactos en la calidad de las relaciones entre ellos. La cualidad de esos intercambios está relacionada también con lo que cada uno espera dar y recibir como contrapartida. El contrato psicológico, aunque pueda ser concebido como de dimensión subjetiva, o tal vez intersubjetiva, tiene en cuenta intercambios esperados, sean sustentados en expectativas (más genéricos), o apoyados en obligaciones y derechos de cada una de las partes. Se abre un camino promisorio para discusiones sobre la moral en el establecimiento de intercambios proyectados entre dos actores implicados en una relación de trabajo, especialmente a través del aumento de la sensibilidad del empoderado para con el otro, el menos empoderado. La insensibilidad para con el trabajador en desventaja aumenta las opciones de desequilibrio en los intercambios.

La percepción de desequilibrio en los intercambios tiene impactos en la evaluación que el trabajador hace de la calidad de ese vínculo que establece con el empleador. La discusión sobre el estado de los contratos y sus efectos (con especial énfasis en las percepciones de ruptura) crece en importancia en la literatura. Autores como Conway y Briner (2002), y Guest y Conway (2002), consideran que el estado de los contratos psicológicos puede ser definido como una evaluación que el trabajador hace sobre el cumplimiento de las promesas y obligaciones del empleador para con él, con implicaciones para el fortalecimiento o ruptura del grado de confianza depositado en esa relación. Para Robinson y Morrison $(1995,2020)$, a pesar de esto, la percepción de quiebra o ruptura del contrato llevada al extremo generaría respuestas emocionales de mayor intensidad de parte del trabajador, por ser considerada como una violación, desde el punto de vista moral, más grave que la percepción de quiebra.

La literatura trae innúmeras evidencias de los efectos del estado de los contratos sobre las actitudes y los comportamientos del trabajador (Conway, Guest \& Trenberth, 2011; Epitropaki, 2013; Jafri, 2012; Lapalme, Simard \& Tremblay, 2011; Pate, Martin \& McGoldrick, 2003; Robbins, Ford \& Tetrick, 2012), como sobre la insatisfacción en el trabajo (Coyle-Shapiro \& Kessler, 2000; Robinson \& Rousseau, 1994; Turnley \& Feldman, 2000). Apoyados em Rousseau (1989), Conway et ál. (2011) presentan evidencias de que los efectos negativos de la ruptura de los contratos psicológicos tienden a suplantar los beneficios del cumplimiento. Los principales efectos perjudiciales se notan en el bienestar afectivo, en la satisfacción con el trabajo y en la fragilización del compromiso organizacional (Lapalme et ál., 2011). Los resultados del estudio 
desarrollado por Epitropaki (2013) señalan que la percepción de ruptura de los contratos psicológicos tiene efectos negativos sobre la identificación con la organización. Un metaanálisis realizado por Robbins et ál. (2012) concluyó sobre efectos negativos de la percepción de injusticia y ruptura del contrato psicológico en la salud física y mental de los trabajadores.

Otros estudios señalan la importancia de entender las circunstancias que llevan al sentimiento/percepción de violación para identificar formas de minimizar respuestas destructivas (Robinson \& Morrison, 2000; Turnley \& Feldman, 2000). El estudio desarrollado por Luksyte, Spitzmueller y Maynard (2011) identificó el efecto de los contratos psicológicos inadecuados y comportamientos desviados. Los resultados indican que a pesar de que trabajadores cualificados soporten funciones descualificadas frente a la crisis económica y la recesión, adoptan el cinismo y comportamientos contraproductivos. En un estudio que implicó tercerizados que ejecutaban las mismas funciones, se concluyó que los tercerizados se muestran menos dispuestos a permanecer en la organización, aun existiendo esa posibilidad. El modelo de contrato psicológico identificado en ese escenario se caracteriza por la oferta de obediencia formal a la jerarquía dominante y tolerancia a cierta inestabilidad coyuntural, mientras exista empleo pero no existan privilegios personalizados. El intercambio se caracteriza, de esta manera, por un modelo de relativa naturalización de la precarización (Rios, 2007; Rios \& Gondim, 2010b).

En función de acompañar la tendencia de pensar el contrato psicológico como un sistema de intercambios, las escalas propuestas por Sels et ál. (2004), con base en el modelo de Janssens et ál. (2003), fuero probadas en una muestra de trabajadores brasileños (Rios \& Gondim, 2015). La resultante factorial encontrada para cada una de las dos escalas de obligaciones, la del empleado y el empleador, fue la siguiente: la escala de obligaciones del empleado quedó compuesta por cuatro factores que denominamos obediencia, inversión personal, inversión profesional y flexibilidad. Obediencia hace referencia a qué tanto el empleado está dispuesto a ajustarse a las normas y reglas organizacionales (ejemplos: "mi empleador puede esperar que yo lidie bien con los imprevistos en situaciones de trabajo...", "toleré cambios introducidos por la empresa"). La inversión personal está relacionada con las actitudes y los comportamientos que demuestran implicación personal con la organización (ejemplos: "invertir tiempo y energía en esa empresa", "me quiero desarrollar en esa empresa"). Inversión profesional refiere las actitudes y los comportamientos que demuestran compromiso con la carrera y el desempeño competente en el trabajo (ejemplos: "indique explícitamente mis deseos y planes de carrera; "establezca con claridad lo que es importante para mí en mi trabajo"). Flexibilidad se refiere al reconocimiento de la existencia de diferencias de demandas individuales en la organización que exigen renegociación de 
contratos (ejemplos: "querer hacer acuerdos individuales", "tener demandas diferentes de otros empleados").

En relación con la escala de obligaciones del empleador, la solución encontrada fue también de cuatro factores, denominados de la siguiente manera: justicia procedimental, reconocimiento personal, reconocimiento profesional y justicia distributiva. Justicia procedimental se refiere a la contrapartida ofrecida por el empleador en relación con las actitudes y los comportamientos de obediencia del empleado (ejemplos: "espero de mi empleador que describa el criterio de evaluación del desempeño de la empresa”, “...describa sin ambigüedad mis derechos en la empresa”). Reconocimiento personal está relacionado con la contrapartida de la organización para con la inversión personal del empleado (ejemplos: "mantener los acuerdos, aunque las circunstancias cambien", "ser apreciado por lo que hago y por quien soy"). Reconocimiento profesional se refiere a la contrapartida de la organización para con la inversión profesional del empleado (ejemplos: "que me ofrezca seguridad en el empleo", "me ofrezca oportunidades para el desarrollo de carrera"). Justicia distributiva se refiere al reconocimiento de las diferencias de demandas individuales en la organización que exigen que sean ofrecidas posibilidades de renegociación de contratos (ejemplos: "que trate igualmente a todos los empleados del mismo nivel"; "considere los acuerdos como aplicables a todo el grupo, departamento o equipo") (Rios \& Gondim, 2015). El avance de esta medida es el presentar la posibilidad de generar un indicador de reciprocidad (IR), resultante de la sustracción de puntajes de obligaciones del empleador y de obligaciones del empleado. El reconocimiento personal del empleador es recompensado por la inversión personal del empleado. De la misma manera, el reconocimiento profesional del empleador está acompañado, en reciprocidad, por la inversión profesional del empleado en la organización. El reconocimiento de que la organización está orientada por principios de justicia distributiva lleva al trabajador a retribuir con obediencia. Finalmente, la justicia procedimental por parte de la organización hace que el trabajador, a cambio, sea más flexible y tolere diferencias e idiosincrasias. Esa perspectiva de contrapartida de las obligaciones de empleadores y empleados permite monitorear el desequilibrio entre las partes, ofreciendo insumos para emprender acciones de gestión que busquen restaurar el equilibrio. Aumentan entonces las oportunidades de establecer contratos psicológicos sobre bases menos injustas.

Como se ha mostrado, la reciprocidad es otro aspecto clave para la formulación de un contrato psicológico como construcción y reconstrucción del vínculo. En la visión de Gouldner (1960), hay dos formas de reciprocidad: la homomórfica y la heteromórfica. Los intercambios homomórficos se definen como equivalentes en términos de valores, contenido y forma. Un ejemplo de intercambio homomórfico 
es el del trabajador que extiende su jornada de trabajo por la urgencia de demandas, pero espera reciprocidad equivalente; es decir, que el empleador le libere un día de trabajo para participar de un evento social familiar. Lo que está siendo intercambiado es el tiempo. Por eso es homomórfica. Los intercambios heteromórficos son practicados de forma más común en nuestra sociedad. El trabajador considera que es obligación del empleador ofrecer seguridad en el empleo, pagos al día, etcétera, como reciprocidad por su productividad. Son intercambios de contenidos y formas diferenciadas. Sin embargo, los intercambios homomórficos o heteromórficos son equivalentes para efectos de criterio de justicia, pues en sentido estricto lo que define un tipo de intercambio como justo, o sea, representativo del término, depende de la comprensión de lo que cada parte considera como deber u obligación de sí y del otro, para que se mantenga la reciprocidad en niveles aceptables. Es decir, se admite que el trabajador pueda considerar como justos tanto los intercambios homomórficos como los heteromórficos.

Con el propósito de avanzar en la construcción de un modelo de contrato psicológico que llegara a contemplar la naturaleza de los intercambios homomórficos y heteromórficos, se propuso y probó empíricamente una medida para evaluar el contrato psicológico de docentes de nivel superior (Rios, 2015; Rios \& Gondim, 2015, 2017). El modelo concibe dos tipos de intercambios esperados por los docentes en su relación con las instituciones educativas empleadoras: los académicos y los institucionales, ambos con la posibilidad de ser homomórficos o heteromórficos. Los primeros unen aspectos relativos a las actividades de enseñanza y de investigación. Los segundos implican obligaciones del docente para con la institución educativa y sus políticas organizacionales y pedagógicas. La tabla 1 presenta algunos ejemplos de intercambios homomórficos académicos e institucionales, y también intercambios heteromórficos. El instrumento completo y los análisis confirmatorios de la estructura de la medida se encuentran descritos en Rios (2015) y Rios y Gondim (2017).

Los resultados del estudio empírico señalan que los docentes sustentan sus contratos psicológicos en obligaciones académicas de enseñanza y obligaciones institucionales más que en obligaciones de investigación, lo que probablemente se deriva del hecho de que los docentes de educación superior, principalmente los de instituciones educativas privadas, desarrollan actividades relacionadas con la enseñanza de forma prevalente. Los resultados sugieren que, para inversiones elevadas, los docentes esperan más contrapartidas homomórficas académicas e institucionales que intercambios heteromórficos. Una de las conclusiones del estudio es que el modelo basado en intercambios homomórficos se hace defendible y operacionalizable, mostrándose como un camino posible para la construcción de relaciones de intercambio más justas, pudiendo ser aplicable en otros contextos organizacionales. 
Tabla 1. Ejemplos de intercambios académicos e institucionales

\begin{tabular}{|c|c|c|c|c|}
\hline \multicolumn{2}{|c|}{ Académicas } & \multicolumn{2}{|c|}{ Institucionales } & \multirow{2}{*}{$\begin{array}{c}\text { Obligaciones } \\
\text { empleador }\end{array}$} \\
\hline Obligaciones & Obligaciones empleador & Obligaciones & Obligaciones empleador & \\
\hline empleado & Homomórficas & empleado & Homomórficas & Heteromórficas \\
\hline $\begin{array}{l}\text { Desarrollar } \\
\text { proyectos de } \\
\text { investigación. } \\
\text { Publicar artículos } \\
\text { científicos. } \\
\text { Dictar clases } \\
\text { con calidad de } \\
\text { contenido y } \\
\text { didáctica. } \\
\text { Mantenerse } \\
\text { actualizado } \\
\text { en su área de } \\
\text { experticia. }\end{array}$ & $\begin{array}{l}\text { Ofrecer recursos } \\
\text { materiales y de tiempo } \\
\text { para la realización } \\
\text { de proyectos de } \\
\text { investigación. } \\
\text { Viabilizar carga horaria } \\
\text { para la dedicación } \\
\text { docente a la producción } \\
\text { científica. } \\
\text { Financiar u ofrecer cursos } \\
\text { de perfeccionamiento } \\
\text { académico a docentes. } \\
\text { Ofrecer capacitación } \\
\text { y soporte para a } \\
\text { incorporación de nuevas } \\
\text { tecnologías de enseñanza. }\end{array}$ & $\begin{array}{l}\text { Obedecer } \\
\text { las reglas y } \\
\text { reglamentos } \\
\text { institucionales. } \\
\text { Cumplir plazos } \\
\text { institucionales } \\
\text { relativos a } \\
\text { las rutinas } \\
\text { académicas de } \\
\text { las actividades } \\
\text { de enseñanza e } \\
\text { investigación. } \\
\text { Participar } \\
\text { en reuniones } \\
\text { promovidas por } \\
\text { la organización } \\
\text { para } \\
\text { familiarizarse } \\
\text { con sus valores, } \\
\text { normas y } \\
\text { directrices. }\end{array}$ & $\begin{array}{l}\text { Explicitar con claridad } \\
\text { las reglas y reglamentos } \\
\text { institucionales en } \\
\text { relación con los valores. } \\
\text { Promover reuniones } \\
\text { para la presentación de } \\
\text { las normas académicas } \\
\text { e institucionales y } \\
\text { divulgar los valores } \\
\text { organizacionales. } \\
\text { Establecer previamente } \\
\text { con los docentes plazos } \\
\text { y procedimientos de las } \\
\text { rutinas académicas. }\end{array}$ & $\begin{array}{l}\text { Asegurar } \\
\text { estabilidad en el } \\
\text { vínculo laboral. } \\
\text { Ofrecer un } \\
\text { plan de carrera } \\
\text { estructurado. } \\
\text { Adoptar una } \\
\text { gestión flexible } \\
\text { que considere las } \\
\text { especificidades } \\
\text { y necesidades } \\
\text { personales de los } \\
\text { docentes. } \\
\text { Dar destaque } \\
\text { institucional a } \\
\text { todas las conquistas } \\
\text { de docentes } \\
\text { dentro y fuera de } \\
\text { la institución de } \\
\text { enseñanza. } \\
\text { Adoptar políticas } \\
\text { de mejora de } \\
\text { remuneración por } \\
\text { tiempo de servicio. }\end{array}$ \\
\hline
\end{tabular}

Fuente: Adaptado de Rios y Gondim (2017).

\section{De la perspectiva del acuerdo en la justicia a la justicia en el acuerdo: el posicionamiento moral del empleador}

Conforme se describió anteriormente, en una sociedad capitalista, cuyos principios son la desigualdad y la propiedad privada de recursos, la búsqueda por establecer relaciones más justas debe ser aún más perseguida, requiriendo sensibilidad, principalmente de aquel que se encuentra en posición privilegiada en el juego de fuerzas. En síntesis, es necesario estar atento a las necesidades de demandas del otro que se encuentra en posición desventajosa y más susceptible a la sujeción a formas tentadoras de explotación. 
Un proyecto de esta naturaleza necesita tener en cuenta que la moralidad se deriva de procesos de desarrollo personal y social. Teóricos del desarrollo de la moralidad, como Piaget (1932/1977) y Kohlberg (1984), destacaban la importancia de vencer diversas modalidades de egocentrismo para alcanzar niveles de moralidad más elevados. Mientras Piaget valoriza el intercambio entre niños, sin inferencia de adultos, para hacer el salto de una moralidad heterónoma a una autonomía moral, Kohlberg ponía énfasis en el proceso educacional, una vez que, para ese pensador, la moralidad se desarrollaría en la medida en que el individuo venga a asumir el punto de vista de la sociedad y de las colectividades. El egocentrismo sería superado por el salto de una moral convencional a una moral posconvencional, difícil de ser alcanzada por estar basada en el contrato social y en una ética universal. La dificultad se encuentra principalmente en fallas de nuestro proceso de socialización, que estimula demasiadamente la autonomía individual para atender los intereses individuales, muchas veces antagónicos a los intereses colectivos. Atender los intereses colectivos requiere despojarse de sus intereses individuales, o sea, fuerza moral.

Si los intereses individuales se sobreponen a los intereses colectivos, y eso se extiende a todas las esferas de la vida, obviamente dicho evento repercutirá en la esfera del trabajo. Al final, el proceso de socialización para el trabajo, que incluye establecer relaciones contractuales de trabajo, es distinto para quienes tienen más oportunidades de convertirse en patrones, en comparación con aquellos que se ven condenados a vender su fuerza de trabajo. En las clases sociales más pobres, el niño asume muy temprano diversas formas y papeles de trabajo. EL modelo de trabajo aprendido es el destituido de sentido y significado. Sirve apenas para garantizar la sobrevivencia de modo precario e inmediato. El pobre ve con "naturalidad" su condición de trabajador desprovisto de recursos y medios de transformación de su realidad.

En las clases más ricas, el proceso de socialización para el trabajo es distinto. Se busca cultivar la creencia de que la única forma de distanciarse de un modelo de trabajador descualificado es postergar el ingreso al mundo del trabajo. Vivir la infancia, estudiar para aumentar el repertorio de conocimientos y de habilidades aumenta la oportunidad de demarcar el posicionamiento futuro en el mundo del trabajo. ¿Qué oportunidades tendría un joven, proveniente de una familia adinerada, que lo eximió de trabajos descualificados y le permitió viabilizar el pleno desarrollo de sus potenciales, de ser sensible a las necesidades de aquel otro, el pobre, socializado en trabajos de baja cualificación, que cree que esa condición es natural? Pocos reconocen que las condiciones que nos posicionan socialmente nos son dadas por contingencias. $\mathrm{Al}$ final, no se escoge en cuáles condiciones se nace. ¿Quién de manera libre optaría por hacer parte, de antemano, del grupo de los no privilegiados y de los descualificados? 
Apoyados en Kohlberg $(1973,1984)$, enfatizamos en la importancia de la oferta de modelos que permitan la identificación con ambos actores, empleadores y empleados. A fin de cuentas, la identificación afectiva y la imitación de ejemplos morales están en la base de la formación de hábitos promotores de más justicia en las relaciones de trabajo. La propiedad simpatética, como fue descrita por Smith (1759/2002), nos ayuda a localizar en la particularidad de la situación la generalidad de la regla (observador imparcial). La empatía nos hace más sensibles a la condición del otro, haciéndonos dejar la motivación egoísta a favor de la motivación altruista (Hoffman, 1976, 2000). La orientación para el otro abre camino a la solidaridad social, buscando conciliar intereses individuales y del otro (Burns, 1973; Homans, 1962).

Esa sería una vía de cultivar la justicia en las relaciones entre los hombres que se encuentran en desigualdades. "Si la igualdad fuese un valor fácilmente operacionalizado en el mundo 'real', tal vez no hubiese necesidad de recurrir al concepto de justicia como institución social. Si el hombre pudiese, de hecho, ejercer la moderación sin ninguna forma de coacción, la justicia se tornaría inútil” (Gondim, 2020, p. 86).

Si la justicia no es un dispositivo natural, sino creado para forzar a los hombres a llegar al término medio, el hombre necesita ser socializado en el ejercicio de la práctica moral para poder incorporar en su repertorio actitudinal y comportamental buenos hábitos de promoción de la justicia. La oferta de modelos es un buen comienzo, y el entrenamiento de ponerse en el lugar del otro también. En una sociedad que legaliza formas de explotación del trabajo, aumenta la responsabilidad individual de aquel que detiene mayor control sobre la relación, el empleador.

Algunos obstáculos para la concretización de relaciones de trabajo más justas de parte del empleador pueden estar asentadas, según Lersch y Sarró (1964), en dos tipos principales de incapacidad: dificultad afectiva de renunciar y la cobardía de decidir y asumir las consecuencias de allí derivadas. Sobrepasar esos límites requiere de apoyo social, para no solamente emprender una crítica de los modelos, sino recompensar decisiones moralmente implicadas que tengan en cuenta la búsqueda de conciliación de intereses, aunque parcialmente, sin excesos y sin falta. Al final, el empleador encuentra, en una sociedad individualista, innúmeras justificaciones para no actual moralmente con el empleado. El actuar moral envuelve fortalecer el self moral y promover la descentración del yo por el respeto a la alteridad. Observen que estamos hablando de respeto, para lo que no se admite una anulación o derrota del otro. La moderación o equilibrio minimiza el sufrimiento de límites impuestos por constricciones de una sociedad apoyada en la desigualdad. La explotación solo encuentra brechas en una sociedad que se aprecia por la gran inequidad, y minimizar esa desigualdad constituye el objetivo de la justicia. 
El reconocimiento por parte de empleadores/contratantes de que los contratos psicológicos son manifestaciones de la subjetividad, no necesariamente declarada, de dos partes con diferentes niveles de poder, y que se comprometen en un proceso de interacción social de trabajo con obligaciones mutuas, es un buen comienzo para establecer relaciones de intercambios menos desiguales. Ambos inician la interacción suponiendo asumir un compromiso que envuelve derechos y deberes, obligaciones y contrapartidas. Eso requiere reconocer al otro en la interacción. Es admitir que una relación envuelve bidireccionalidad y reciprocidad para que sea legitimada. Las expectativas sobre qué tipo de reciprocidad, homomórfica o heteromórfica, sería la más justa, impone considerar las condiciones en que cada una de las partes se encuentra y cuáles son las concesiones que se disponen a hacer. Lo dado por realidad es que en un sistema social que tiene como principio la desigualdad, se convierte en imperativo reconocer que las concesiones deben tener en cuenta los límites tolerables de la desigualdad, sin corromper relaciones sociales.

\section{Referencias}

Argyris, C. (1960). Understanding organizational behavior. Dorsey.

Arnold, J. (1996). The psychological contract: a concept in need of closer scrutiny? European Journal of Work and Organizational Psychology, 5(4), 511-520. doi: $10.1080 / 13594329608414876$

Aristoteles (1985 [circa 300 a. C.]). Ética a Nicômaco. (Mário da Gama Kury, trad.). Editora Universidade de Brasília.

Blasi, A. (1983). Moral cognition and moral action: A theoretical perspective. Development Review, 3(2), 178-210. doi: 10.1016/0273-2297(83)90029-1

Brasil. (1943). Decreto-Lei 5.452, de $1^{\circ}$ de maio de 1943. Aprova a Consolidação das Leis do Trabalho. http://www.planalto.gov.br/ccivil_03/decreto-lei/Del5452.htm.

Brasil. (2017a). Presidência de República. Casa Civil. Medida Provisória 808 de 14 de novembro de 2017. http://www.planalto.gov.br/ccivil_03/_ato2015-2018/2017/Mpv/mpv808. htm

Brasil. (2017b). Ministério da Justiça. Infopen. http://dados.mj.gov.br/dataset/infopen-levantamento-nacional-de-informacoes-penitenciarias

Brasil (2017c) Presidência da República. Casa Civil. Lei 13.467 de 13 de julho de 2017. http:// www.planalto.gov.br/ccivil_03/_ato2015-2018/2017/lei/113467.htm

Burns, T. R. (1973). A structural theory of social exchange. Acta Sociologica, 16, 188-208.

Caygill, H. (2000). Dicionário de Kant. Jorge Zahar Editor.

Chiuzi, R. M. (2012). As dinâmicas de formação e continuidade dos contratos psicológicos de trabalho nas relações flexibilizadas. (Tesis de doctorado). Universidade de São Paulo, Instituto de Psicologia. 
Chiuzi, R. M. (2014). As dinâmicas de formação e continuidade dos contratos psicológicos de trabalho. (Tesis de doctorado). Universidade de São Paulo, Instituto de Psicologia.

Conway, N. \& Briner, R. (2005). Understanding psychological contracts at work: a critical evaluation of theory and research. Oxford.

Conway, N. \& Briner, R. B. (2002). A daily diary study of affective responses to psychological contract breach and exceeded promises. Journal of Organizational Behavior, 23, 287302.

Conway, N.; Guest, D. \& Trenberth, L. (2011). Testing the differential effects of changes in psychological contract breach and fulfillment. Journal of Vocational Behavior, 79(1), 267-276.

Coyle-Shapiro, J. \& Kessler, I. (2000). Consequences of the psychological contract for the employment relationship: a large-scale survey. Journal of Management Studies, 37(7), 903-930.

Cullinane, N. \& Dundon, T. (2006). The psychological contract: A critical review. International Journal of Management Reviews, 8(2), 113-129.

Epitropaki, O. (2013). A multi-level investigation of psychological contract breach and organizational identification through the lens of perceived organizational membership: Testing a moderated-mediated model. Journal of Organizational Behavior, 34(1), 65-86.

Gino, F. Schweitzer, M. E., Mead, N. L. \& Ariely, D. (2011). Unable to resist the temptation: how self-control depletion promotes unethical behavior. Organizational Behavior and Human Decision Process, 115(2), 191-203. doi: 10.1016/j.obhdp.2011.03.001_

Gondim, S.M.G. (2020). "Os reis juízes devoradores de presentes”: um ensaio sobre as complexas relações entre moral e ação moral. Buscando a sensibilização de empregadores nas contratações de trabalho. Editora Appris.

Gondim, S.M.G. \& Rios, M.C. (2015). Contrato psicológico de trabalho. Em: P. F. Bendassoli \& J.E. Borges-Andrade. Dicionário de psicologia do trabalho e das organizações (pp. 245 252). Casa do Psicólogo/Pearson.

Gontijo, E. D. (2006). Os termos 'ética' e 'moral'. Mental, 4(7), 127-135. http://pepsic.bvsalud. org/scielo.php?script=sci_arttext\&pid=S1679-44272006000200008.

Gouldner, A. W. (1960). The norm of reciprocity: A preliminary statement. American Sociological Review, 25, 161-178.

Guest, D. (1998). Is the psychological contract worth taking seriously? Journal of Organizational Behavior, 19, 649-664. http://www.jstor.org/stable/3100281?seq=1\#page_scan_tab_ contents.

Guest, D. (2004a). The psychology of the employment relationship: an analysis based on the psychological contract. Applied Psychology, 53(4), 541-555. doi: 10.1111/j.14640597.2004.00187.x 
Guest, D. (2004b). Flexible employment contracts, the psychological contract and employee outcomes: an analysis and review of the evidence. International Journal of Management Review, 5-6(1), 1-19. doi: 10.1111/j.1460-8545.2004.00094.x

Guest, D. \& Conway, N. (2002). Communicating the psychological contract: An employer perspective. Human Resource Management Journal, 12, 22-38. doi: 10.1111/j.17488583.2002.tb00062.x

Hegel, G. W. F (1807/1992). A fenomenologia do espírito (Paulo Meneses, Trad.). Vozes.

Hoffman, M. L. (1976). Empathy, role taking, guilt, and development of altruistic motives. En T. Lickona (ed). Moral development and behavior: Theory, research, and social issues (pp. 124-141). Holt, Rinehart and Winston.

Hoffman, M. L. (2000). Empathy and moral development: Implications for caring and justice. Cambridge University Press.

Homans, G. C. (1958). Social Behaviour as Exchange. American Journal of Sociology, 63(6), 597-606. http://www.journals.uchicago.edu/doi/pdfplus/10.1086/222355.

Homans, G. C. (1962) Sentiments and Activities: Essays in Social Science. The Free Press of Glencoe.

Homans, G. C. (1974). Social Behaviour: Its Elementary Forms. Harcourt Brace Jovanovich, Inc.

Jafri, H. (2012). Influence of psychological contract breach on organizational citizenship behaviour and trust. Psychological Studies, 57(1), 29-36.

Janssens, M.; Sels, L. \& Van Den Brande, I. (2003). Multiple types of psychological contracts - A six-cluster solution. Human Relations, 56(11), 1349-1378.

Jones, T.M. (1991). Ethical decision making by individuals in organizations: An issue-contingent model. Academy of Management Review, 16(2), 366-395. doi: 10.5465/ AMR.1991.4278958.

Kant, I. (1787/1994). Crítica da Razão Pura (3a. Ed.) (Manuela Pinto dos Santos \& Alexandre Fradique Morujão, Trad.). Fundação Calouste Gulbenkian.

Kohlberg, L. (1976). Moral stages and moralization: The cognitive-developmental approach. En T. Lickona (ed). Moral development and behavior: Theory, research, and social issues (pp. 31-52). Holt, Rinehart and Winston.

Kohlberg, L. (1984). The Psychology of Moral Development: The Nature and Validity of Moral Stages. Essays on Moral Development, vol. 2. Harper \& Row.

Krüger, H. (2005). Avaliação de trabalhos científicos. OઐS, Organizações \& Sociedade, 12(33), 179-182.

Lapalme, M.È.; Simard, G. \& Tremblay, M. (2011). The influence of psychological contract breach on temporary workers' commitment and behaviors: A multiple agency perspective. Journal of Business and Psychology, 26(3), 311-324.

Lersch, P. \& Sarró, R. (1964). La estructura de la personalidad. Editorial Scientia. 
Levinson, H., Price, C., Munden, K., Mandl, H. \& Solley, C. (1962). Men, Management, and Mental Health. Harvard.

Luksyte, A.; Spitzmueller, C. \& Maynard, D.C. (2011). Why do overqualified incumbents deviate? Examine multiple mediators. Journal of Occupational Health Psychology, 16(3), 279-296.

Malvezzi, S. (2011, maio). Os desafios da reciprocidade dos contratos psicológicos diante do enfraquecimento dos vínculos. Comunicação apresentada no $7^{\circ}$ Congresso Norte Nordeste de Psicologia, Salvador. http://www.conpsi7.ufba.br/

Mazar, N., Amir, O. \& Ariely, D. (2008). The dishonesty of honest people: A theory of self-concept maintenance. Journal of Marketing Research, 45, 633-644. http://people. duke.edu/ dandan/webfiles/PapersPI/Dishonesty\%20of\%20Honest\%20People.pdf.

Pate, J., Martin, G. \& McGoldrick, J., (2003). The impact of psychological contract violation on employee attitudes and behavior, Employee Relations, 25(6), 557-573.

Rest, J. R. (1986). Moral development: Advances in research and theory. Praeger.

Rest, J. R. (1994). Background: Theory and research. In J. R. Rest \& D. Narváez (Eds.). Moral development in the professions: Psychology and applied ethics (pp. 1-26). Lawrence Erlbaum Associates Inc.

Piaget, J. (1932/1977). O julgamento moral da criança. Mestre Jou.

Reynolds, S.J. \& Miller, J.A. (2015). The recognition of moral issues: moral awareness, moral sensitivity and moral attentiveness. Current Opinion in Psychology, 6, 114-117. doi: 10.1016/j.copsyc.2015.07.007

Rios, M.C. (2007). Atribuições iguais, vínculos organizacionais desiguais: Investigando os Contratos Psicológicos de terceirizados e não-terceirizados. (Tesis de maestría en Psicología). UFBA - PPGP, Salvador

Rios, M.C. e Gondim, S.M.G. (2010b). Contratos psicológicos e terceirização: um estudo das relações entre vínculos e as práticas de gestão de pessoas. Revista O\&S, 55(17), 689-703.

Rios, M.C. (2015) Contratos Psicológicos, Centralidade do Trabalho, Autorregulação e Estados Emocionais: Um estudo com docentes do ensino superior. (Tesis de doctorado). Universidade Federal da Bahia, Instituto de Psicologia.

Rios, M.C. \& Gondim, S.M.G. (2017). Escala de contrato psicológico docente: estrutura e evidências de validação. Revista Gestão Universitária na América Latina - GUAL, 10(3), 1-16. https://periodicos.ufsc.br/index.php/gual/article/view/1983-4535.2017v$10 \mathrm{n} 3 \mathrm{p} 1 / 35267$

Robbins, J.M.; Ford, M.T. \& Tetrick, L.E. (2012). Perceived unfairness and employee health: A meta-analytic integration. Journal of Applied Psychology, 97(2), 235-272.

Robinson, S.L. \& Morrison, E.W. (1995). Psychological contract and OCB: the effect of unfulfilled obligations on civic virtue behavior. Journal of Organizational Behavior, 16, 289298. https://doi.org/10.1002/job.4030160309 
Robinson, S. L. \& Morrison, E. W. (2000). The development of psychological contract breach and violation: a longitudinal study. Journal of Organizational Behavior, 21, 525-546. doi: 10.1002/1099-1379(200008)

Robinson, S. L. \& Rousseau, D. M. (1994). Violating the psychological contract: not the exception but the norm. Journal of Organizational Behavior, 15, 245-259. doi:10.1002/ job.4030150306

Roehling, M.V. (1997). The origins and early development of psychological contract construct. Journal of Management History, 3(2), 204-217.

Rosenfield, C. L. \& Pauli, J. (2012). Para além da dicotomia entre trabalho decente e trabalho digno: reconhecimento e direitos humanos. Caderno CRH, 25(65), 319-329. doi:10.1590/S0103-49792012000200009.

Rousseau, D.M. (1989). Psychological and Implied Contracts in Organizations. Employee Responsibilities and Rights Journal, 2(2), 121-139.

Rousseau, D. (1995). Psychological Contracts in Organizations: Understanding Written and Unwritten Agreements. Sage.

Rousseau, D.M. (2001). Schema, promise and mutuality: The building blocks of the psychological contracts. Journal of Occupational and Organizational Psychology, 74, 511-541.

Rousseau, D. (2005). I-Deals: Idiossyncratic Deals Emplyees Bargain for Themselves. Sharpe.

Saltzstein, H. D. (1994). The relation between moral judgment and behavior: A social-cognitve and decision-making analysis. Human Development, 37(5), 299-312. doi:10.1159/000278274.

Schein, E. H. (1965). Organizational Psychology. Prentice-Hall Inc.

Sels, L.; Janssens, M. \& Van Den Brande, I. (2004). Assessing the nature of psychological contracts: a validation of six dimensions. Journal of Organizational Behavior, 25(4), 461488.

Shore, L.M. \& Barksdale, K. (1998). Examining the degree of balance and level of obligation in employment relationship: A social exchange approach. Journal of Organizational Behavior, 19, 731-744.

Skorupsdki, J. (2002). Ética. In N. Bunnin \& E.P.Tsiu-James (Orgs.). Compêndio de Filosofia (pp. 197-227). Edições Loyola.

Smith, A. (1759/2002). The theory of moral sentiments. Cambridge University Press.

Tenbrunsel, A. E. \& D. M. Messick (2004). Ethical Fading: The Role of Self Deception in Unethical Behavior. Social Justice Research, 17(2), 223-236. doi: 10.1023/B:SO RE.0000027411.35832.53.

Tenbrunsel, A. E \& Smith-Crowe, K. (2008). Ethical decision making: where we've been and where we're going. Academy of Management Annals, 2(1), 545-607.

Turnley, W.H. \& Feldman, D.C. (2000). Re-examining the effect of psychological contract violations: unmet expectations and job dissatisfaction as mediators. Journal of Organizational Behavior, 21, 25-42. 
Vesga, J. J. (2020). Evolución y usos del contrato psicológico. En C. M. Alcover (ed.). La vigencia del contrato psicológico. Aproximaciones teóricas y empíricas desde las Américas. Universidad Católica de Colombia.

Welsh, D. T. \& Ordóñez, L. D. (2013). Conscience without cognition: the effects of subconscious priming on ethical behavior. Academy of Management Journal, 57(3), 723-742. doi: 10.5465/amj.2011.1009. 
SEGUNDA PARTE APROXIMACIONES EMPÍRICAS SOBRE EL CONTRATO PSICOLÓGICO 



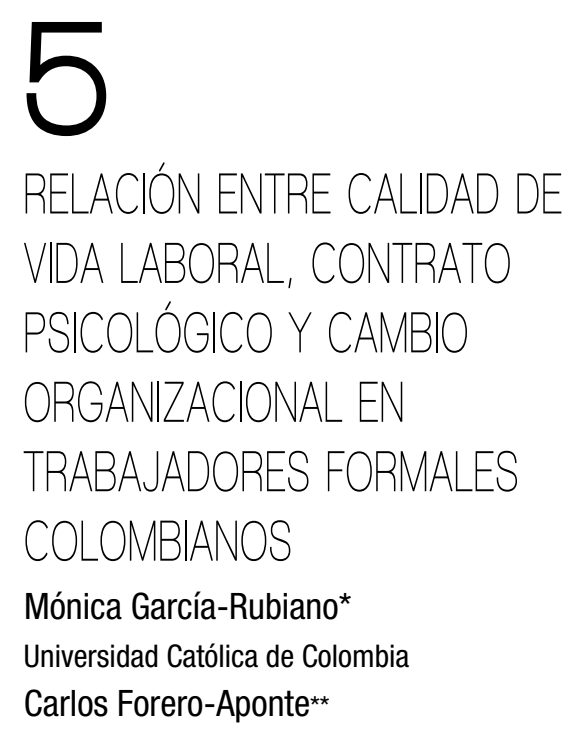

\section{Introducción}

El cambio organizacional es un fenómeno que surge como consecuencia de las diversas trasformaciones a las que está expuesta la sociedad actualmente; la ciencia, la tecnología, la economía, la política y otros ámbitos, actúan de manera significativa para que la organización logre mantenerse y posicionarse en el medio competitivo y dinámico. Para muchas organizaciones implementar un proceso de cambio no es sencillo, pero a otras se les facilita ya que están abiertas al mismo. Cada organización debe analizar y examinar con detalle los beneficios y pérdidas de adoptar un proceso de cambio (Jacobs, Witteloostuijn \& Christe-Zeyse, 2013).

Es natural, y en ocasiones necesario, que las organizaciones atraviesen procesos de cambio, ante los cuales pueden sentir preocupación; sin embargo, asumirlos y afrontarlos trae múltiples beneficios en la organización, y el éxito o el fracaso dependerán de las estrategias y el compromiso con que se asuman dichos procesos. Por esta razón, también es fundamental que la organización se proyecte y direccione hacia las demandas exigidas por el medio, puesto que una sociedad altamente influenciada por la competitividad y el mercado global requiere de organizaciones que se acoplen y se puedan adoptar de manera positiva a los cambios. En el contexto moderno, estos cambios provocan una constante adaptación y aprendizaje, nuevas formas de trabajo y nuevas relaciones entre las personas al interior de las organizaciones (Rafferty \& Restubog, 2010).

\footnotetext{
${ }^{*}$ https://orcid.org/0000-0002-7699-502X

${ }^{* *}$ https://orcid.org/0000-0003-0132-4595
} 
Es fundamental resaltar la importancia que tienen los principales componentes de la organización en el proceso de cambio, es decir, su estructura, los procesos, las herramientas, la tecnología, su cultura y sus miembros (Lines, 2005). Sin desmérito de los demás componentes, involucrar a los empleados es un aspecto primordial para lograr el cambio, puesto que son los ejecutores de las funciones que mantienen a la organización (Acosta, 2002).

Para implantar el cambio, se debe sensibilizar a las personas sobre la necesidad del mismo, así como de su papel en el proceso. Un aspecto que ayuda a revelar la voluntad de cambio en el personal reside en las experiencias que tienen o han tenido con el cambio, esto partiendo del supuesto de que el cambio no es considerado agradable cuando el personal enfrenta la transformación de muchas de las estructuras que hacen parte de su rutina diaria de trabajo; además, el cambio es rechazado ya que por lo general implica reuniones intensas, falta de claridad en el objetivo final y en los pasos para efectuarlo. Estas circunstancias pueden derivar en conflictos, resultados inciertos, frustración y angustia (Rafferty \& Restubog, 2010).

Implementar el cambio organizacional implica tener en cuenta, primero, las características de la organización, y segundo, los objetivos o la finalidad perseguida con el cambio. Ambos factores movilizan o impiden su gestión. En cuanto a las características que rigen la organización, por ejemplo, no es lo mismo implementar un cambio en una organización pequeña que en una grande, o efectuar un cambio en una organización con tramos de control estrechos que en una organización con tramos de control amplios; la diversidad de características que posee una empresa es amplia, por esta razón, si se conocen las características relevantes y se acompañan o se encaminan junto con los objetivos organizacionales y la finalidad del cambio, pueden conseguirse resultados satisfactorios (Oreg, 2006).

La gestión del cambio debe clarificar dos aspectos: las fases del cambio y los elementos para la gestión del cambio. En las fases del cambio se tiene en cuenta: 1) identificar la necesidad de cambio, 2) diagnóstico de la situación actual, 3) planeación de las acciones, 4) implementar el cambio y hacer seguimiento, y 5) evaluación de los cambios en la medida en que se produzcan. Con el fin de que estas fases se desarrollen de manera adecuada, las organizaciones consideran algunos elementos para gestionarlo. En primer lugar, se encuentran las personas que apoyan los cambios intangibles, en donde se disponen, por parte de la alta dirección de equipos, sistemas de comunicación, cultura y liderazgo; en segundo lugar, se encuentra el cambio tangible, en donde se utilizan herramientas con las que la organización cuenta para ayudar al cambio y se imparten directamente con las personas responsables del mismo (Jacobs et ál., 2013). 
Las condiciones de cambio dan origen a actitudes y comportamientos en las personas que están inmersas en la organización. Estas se pueden clasificar en: los que aprueban, los indiferentes y los que se oponen. Es por esto que cualquier cambio, ya sea de carácter técnico, coordinado, organizacional, socioeconómico, político o cultural, siempre promueve la formación de estos grupos, lo que puede contribuir al aumento de la resistencia (Lines, 2005).

La resistencia no solo se evidencia en el componente comportamental, actualmente los componentes cognitivos y afectivos desempeñan un papel importante en la manera como el empleado enfrenta el cambio dentro de la organización; por esto la resistencia al cambio puede definirse en tres dimensiones: afectiva, conductual y cognitiva. En primer lugar, la dimensión afectiva tiene que ver con los sentimientos positivos o negativos de los empleados cuando se enfrentan con un cambio; la segunda dimensión, comportamental, de acuerdo con Oreg (2006) implica acciones o intenciones de actuar en respuesta al cambio: una persona puede pensar en quejarse a la gerencia o convencer a sus colegas de que el cambio es un bien o un mal; por último la dimensión cognitiva se refiere a creencias positivas o negativas de los empleados como resultado de una evaluación mental del cambio (Eagly et ál., 1999).

Cuando un proceso de cambio tiene lugar, uno de los primeros obstáculos para la consecución del objetivo final son las personas. Aspectos como la falta de motivación, prevenciones, resistencias, altercados, perjuicio, diferencias en los intereses, falta de colaboración y de disposición, deficiencia en la información, entre otros, son señalados como fundamentos del fracaso del cambio en las organizaciones. Así, ocurre que muchos procesos de cambio se centran en las organizaciones y los estímulos que demandan ser transformados, procesos que se tornan muchas veces extensos y costosos, y al final, luego de presentarse el fracaso, se entiende que obedeció a la falta de apoyo del personal (Oreg, 2005).

Asimismo, como algunas organizaciones hacen énfasis en el cambio organizacional, también deben tener en cuenta la importancia del contrato psicológico y su influencia directa sobre el proceso de cambio, pues todas las expectativas y creencias del empleado resultan ser claves en el desarrollo de este proceso. El contrato psicológico tiene una estrecha relación con el cambio organizacional, es decir, cuando una organización atraviesa un cambio, las condiciones laborales se modifican afectando el contrato psicológico del individuo; por esto, el modo en el que se maneje el cambio determinará también la forma en la que el empleado interprete la situación y esté dispuesto a colaborar o a ser apático (Heuvel \& Schalk, 2009).

Drucker (1996) señala que el concepto de contrato psicológico adquiere relevancia debido a los cambios de las condiciones laborales en las organizaciones, haciendo 
referencia al acuerdo relacional, que se plantea entre el empleador y el empleado cuando se ingresa a una organización y en el transcurso de su actividad laboral. Esta negociación se construye a partir de las expectativas, creencias, metas y proyecciones que tiene el empleador con su contexto de trabajo.

En este punto, la relación laboral tienen un papel primordial, ya que el trabajador le brinda al empleador sus capacidades físicas e intelectuales para el desarrollo de la actividad que va a desarrollar, la cual se relaciona con las expectativas que tienen tanto el trabajador como su empleador (Patrick, 2008).

Se considera importante que el empleado y el empleador sientan que están desempeñando bien sus obligaciones dentro de la organización, para que haya una contribución significativa hacia la organización por parte del trabajador y hacia el empleado por parte de la organización. Sin embargo, las buenas relaciones entre empleado y empleador dentro de la organización siempre están en la búsqueda de mejores condiciones laborales y en procura de mejores oportunidades para ambas partes (Sousa, 2006). Estas relaciones pueden generar efectos positivos y negativos en la organización, es decir, cuando existe una buena relación entre colaborador y empleador, ambos pueden aumentar la productividad y por ende perseguir los mismos objetivos organizacionales, o al contrario, puede ocurrir que en una organización existan problemas de entendimiento entre empleado y empleador, generando altercados o inconvenientes en la producción, lo que puede alterar gravemente el funcionamiento de una organización (Rousseau, 1989).

La percepción que tienen las partes del deterioro de la relación laboral por incumplimiento de las promesas u obligaciones por una de las partes es característico de la ruptura del contrato psicológico (Robinson, 1996)

Para entender cuáles serían las obligaciones de empleados y empleadores en relación con el contrato psicológico, es importante tener conocimiento de las condiciones de los tipos de contrato que resultan en la relación laboral. Para este fin, MacNeil (1985) propone una serie de tipologías de contratos: 1) clásicos: se establecen de forma escrita o verbal, las condiciones laborales son claras; 2) neoclásicos: integran elementos que incorporan mecanismos de mediación para resolver inconvenientes que se presenten en la ejecución; 3) relacionales: vislumbran la relación empleado-empleador de una manera holística que permite realizar ajustes a las condiciones acordadas en un primer momento.

Es importante para las organizaciones establecer un ambiente laboral que propicie el desarrollo y fortalecimiento de los empleados y la organización, de tal manera que se 
ajusten las necesidades de las partes para una óptima calidad de vida del empleado (Huerta et ál., 2011).

Para Segurado y Argulló (2002), la calidad de vida laboral (CVL) ha sido estudiada desde dos perspectivas, la primera tiene que ver con los intereses organizacionales y la manera de propiciar una calidad de vida adecuada, y la segunda orienta su interés hacia el trabajador, lo que se conoce como calidad de vida psicológica. Estos enfoques pretenden fortalecer la calidad de vida, sin embargo, la manera como despliengan sus objetivos para el logro de esta meta es diferente. Esta dualidad de perspectivas hizo que se crearan más diferencias entre ellas, de las cuales surgieron: 1) Las condiciones objetivas versus condiciones subjetivas del entorno del trabajo: lo objetivo hace relación específica a los aspectos que genera el medioambiente laboral, como son las condiciones laborales, salariales, el horario, entre otros. Por lo tanto, la calidad de vida está influida directamente por la naturaleza y las características del trabajo. Por otra parte, lo subjetivo se refiere a las creencias que tiene el trabajador frente a su realidad laboral y que se relacionan con los valores, actitudes y pautas de comportamiento. 2) Trabajador versus organización. El estudio orientado hacia el trabajador evalúa los elementos que tienen influencia directa en la forma como se percibe el trabajo del empleado. El estudio a nivel de la organización implica un acercamiento global, que concibe a la misma como un sistema abierto y evalúa todos los niveles que pueden estar limitando los objetivos de la calidad de vida laboral. 3) Calidad de vida laboral psicológica versus calidad de vida del entorno del trabajo. La primera hace referencia a las características individuales, que generan expectativas alrededor del trabajo y que incluyen las emociones y las actitudes que ejercen influencia en el trabajador. La segunda se relaciona con el puesto de trabajo y sus características, que pueden generar mayor o menor calidad de vida laboral.

El estudio de las relaciones entre las variables objeto de estudio se documenta en varias investigaciones, sea variable por variable o partir de variables relacionadas.

Por ejemplo, en un estudio previo, García y Forero (2015) señalan la relación entre cambio organizacional y contrato psicológico con una muestra de cien empleados. Se concluye que los trabajadores que asumen el cambio de manera favorable son flexibles ante este. En otro estudio de García y Forero (2016) el objetivo fue identificar la asociación entre calidad de vida laboral y disposición al cambio organizacional, con cien participantes de diferentes empresas de Bogotá. Los resultados obtenidos evidencian correlación de las variables de cambio y calidad de vida al 0,001, a excepción de la variable resistencia al cambio. Se resalta la importancia de la calidad de vida y el compromiso en las tareas, ya que orientan los objetivos que se plantean en la organización y se reflejan en disposición al cambio y productividad de los empleados. 
Por su parte, Giraldo, Peláez y Valencia (2013) evaluaron la relación entre el contrato psicológico en trabajadores con contrato a término fijo y su participación en el bienestar del individuo en su ambiente la1boral. Los autores concluyeron que las causas principales para que los trabajadores renuncien son la falta de espacios que ofrece la organización y la baja motivación relacionadas con las funciones que realizan. Es de destacar que en este caso el salario no figura como la causa principal.

El impacto social de este estudio es brindar un soporte teórico y empírico sobre la relación de las variables objeto de estudio, así como brindar herramientas que les permitan a las organizaciones desarrollar un proceso de cambio adecuado teniendo en cuenta aspectos del comportamiento organizacional.

La pregunta de investigación planteada es: ¿cuál es la relación entre las condiciones de calidad de vida laboral y la percepción del contrato psicológico con el cambio organizacional en trabajadores de empresas de Bogotá? Como objetivo general del estudio se plantea determinar las condiciones de calidad de vida laboral y la percepción del contrato psicológico con relación al cambio organizacional en trabajadores de tres empresas de Bogotá. Los objetivos específicos fueron: 1) identificar la disposición de los trabajadores frente al cambio, 2) identificar las diferentes condiciones de calidad de vida laboral en los trabajadores, 3) identificar los estilos de contrato psicológico en los trabajadores, 4) identificar la correlación de las variables contrato psicológico y calidad de vida laboral con el cambio organizacional.

Se evaluaron las siguientes hipótesis:

H1: A mayor calidad de vida, mayor será la disposición al cambio.

H2: A mayor contrato psicológico, mayor será la disposición al cambio.

H3: La calidad de vida laboral y el contrato psicológico se relacionan con el cambio organizacional.

H4: La calidad de vida y el contrato psicológico se relacionan.

\section{Método}

\section{Participantes}

Participaron voluntariamente cien trabajadores de empresas en proceso de cambio de primer orden. Los criterios de inclusión fueron: trabajadores con más de tres meses de vinculación y participación voluntaria en la investigación. La muestra estuvo 
compuesta en un $60 \%$ por hombres y un $40 \%$ por mujeres; respecto al nivel educativo, el $31 \%$ se encontraba en un nivel técnico; el $29 \%$ secundario; el $22 \%$ profesional y el $18 \%$ primaria; en el estado civil predomina el $56 \%$ de solteros. En cuanto a tipos de contrato, el $79 \%$ tenía contrato a término indefinido, el $10 \%$ a término fijo y el $9 \%$ contrato de aprendizaje.

\section{Tipo de estudio}

La investigación se realizó por medio de un estudio transversal correlacional. Pretende la cuantificación y medición de las variables para calcular el índice de relación y determinar el grado de relación entre las variables en un momento del tiempo específico (Hernández, Fernández \& Baptista, 2010).

\section{Procedimiento}

1. Se realiza la invitación de participación a las organizaciones por medio de cartas o llamadas telefónicas.

2. Una vez las organizaciones aceptan la propuesta, se establecen aspectos logísticos para realizar la aplicación de los instrumentos.

3. Se realiza la aplicación de los instrumentos, se brindan las instrucciones de confidencialidad y se realiza la respectiva aplicación, que se desarrolla de manera grupal.

\section{Instrumentos}

Para el desarrollo de esta investigación se empleó el instrumento de medición del cambio (IMC) (García \& Forero, 2010). El instrumento está constituido por nueve variables principales: a) adaptabilidad, b) liderazgo, c) participación/integración, d) comunicación, e) trabajo en equipo, e) aceptación, f) resistencia al cambio, g) conocimiento de la organización, h) cultura de cambio; tres factores de primer orden: a) factor individual, b) factor grupal y c) factor organizacional; y dos factores de segundo orden a) factor I: gestión del cambio, b) factor II: proyección y desarrollo del cambio. La confiabilidad total de la prueba fue alfa de Cronbach 0,86; en la tabla 1 se presentan las confiabilidades para cada componente de la prueba IMC y las puntuaciones máximas; la puntuación mínima teórica para cada uno de los componentes es 1. 
Relación entre calidad de vida laboral, contrato psicológico y cambio organizacional...

Tabla 1. Confiabilidad por alfa de Cronbach y puntuaciones máximas para los distintos aspectos evaluados por el IMC

\begin{tabular}{|c|c|c|c|c|}
\hline & Variable & \# de ítems & Alfa de Cronbach & Puntuación máxima \\
\hline \multirow{9}{*}{$\begin{array}{l}\text { Variables } \\
\text { generales }\end{array}$} & Adaptabilidad & 5 & 0,512 & 20 \\
\hline & Liderazgo & 6 & 0,776 & 24 \\
\hline & Participación-Integración & 5 & 0,777 & 20 \\
\hline & Comunicación & 5 & 0,709 & 20 \\
\hline & Trabajo en equipo & 4 & 0,743 & 16 \\
\hline & Aceptación & 8 & 0,542 & 32 \\
\hline & Resistencia al cambio & 11 & 0,879 & 44 \\
\hline & $\begin{array}{c}\text { Conocimiento de la } \\
\text { organización }\end{array}$ & 4 & 0,604 & 16 \\
\hline & Cultura de cambio & 3 & 0,77 & 12 \\
\hline \multirow{3}{*}{$\begin{array}{l}\text { Factores de } \\
\text { primer orden }\end{array}$} & Individual & 11 & 0,745 & 44 \\
\hline & Grupal & 14 & 0,845 & 56 \\
\hline & Organizacional & 26 & 0,756 & 104 \\
\hline \multirow{2}{*}{$\begin{array}{c}\text { Factores de } \\
\text { segundo orden }\end{array}$} & Gestión de cambio & 16 & 0,89 & 64 \\
\hline & $\begin{array}{l}\text { Proyección y desarrollo } \\
\text { del cambio }\end{array}$ & 6 & 0,736 & 24 \\
\hline Total & IMC & 51 & 0,86 & 204 \\
\hline
\end{tabular}

Fuente: Elaboración propia.

Para evaluar la calidad de vida laboral se empleó la prueba del mismo nombre, diseñada por Gómez-Rada (2011), que consta de ocho dimensiones: 1) compensación y beneficios, 2) condiciones del ambiente y del trabajo, 3) naturaleza de la tarea, 4) desarrollo y seguridad laboral, 5) democracia organizacional, 6) derechos fundamentales, 7) equilibrio laboral e 8) impacto social. La prueba empleada tiene un total de 39 ítems y consiste en una escala tipo Lickert con valores mínimo de 1 y máximo de 4 por ítem; tiene una confiabilidad de 0,97 obtenida con alfa de Cronbach. Se utilizó esta prueba dada su articulación con la postura de Walton (citado por Toro, 1991). Por último, se utilizó el inventario de contrato psicológico de Rousseau (2000) versión 2, respecto al cual Quijada (2009) define las siguientes clasificaciones y sus respectivas dimensiones: 1) contrato psicológico balanceado: compuesto con tres subdimensiones: a) empleabilidad externa, b) requerimiento de rendimiento dinámico 
y c) desarrollo profesional-mercado interno. 2) Contrato psicológico relacional: sus dimensiones son: a) lealtad y b) estabilidad. 3) Contrato psicológico transaccional, sus dimensiones son: a) estrecho y b) corto plazo. 4) Contrato psicológico, sus dimensiones son: a) erosión, b) incertidumbre y c) no confía. La prueba tiene un total de treinta (30) ítems con valores mínimo de 1 y máximo de 5 y una confiabilidad de 0,084 obtenido con alfa de Cronbach.

\section{Resultados}

La descripción y análisis de los resultados se realizó con el software IBM SPSS Statistics 20. Inicialmente se presentan los análisis descriptivos de la información sociodemográfica y posteriormente el análisis descriptivo de las variables disposición ante el cambio organizacional, calidad de vida laboral y contrato psicológico. También se presenta la evaluación de normalidad de las distribuciones de las subvariables de la investigación mediante el estadístico de prueba Kolmogorov-Smirnov, y para determinar los niveles y significaciones entre las variables y las subvariables se empleó el coeficiente de correlación de Spearman en consideración con la escala de medida de las mismas.

En la tabla 2 se presentan las características sociodemográficas en cuanto a edad, tiempo de vinculación y antigüedad en el cargo. La distribución de la edad presenta asimetría ligeramente positiva, con valores superiores a la media $(\bar{X}=30.25)$ y es ligeramente platicúrtica. En cuanto al tiempo de vinculación y la antigüedad en el cargo, se presentan asimetrías positivas con tendencia leptocúrtica, lo que indica que se trata de distribuciones de carácter homogéneo, con tiempos de vinculación promedio cercano a los dos años $(\bar{X}=1,98)$ y antigüedad cercana a los dos años $(\bar{X}=1,74)$

Tabla 2. Estadísticos socio demográficos

\begin{tabular}{cccc}
\hline Estadísticos & Edad & Tiempo de vinculación & $\begin{array}{c}\text { Antigüedad en el } \\
\text { cargo }\end{array}$ \\
\hline Media & 30,25 & 1,98 & 1,74 \\
Mediana & 28 & 1,54 & 1,21 \\
Moda & 25 & 1 & 1 \\
Desv. típ. & 8,33 & 1,57 & 1,37 \\
Asimetría & 0,64 & 2,19 & 2,94 \\
Curtosis & $-0,74$ & 5,79 & 11,62 \\
\hline
\end{tabular}

Fuente: Elaboración propia. 
En la tabla 3 se presenta la información descriptiva de las subvariables de cambio organizacional; al evaluarse la tendencia de la forma de las distribuciones mediante el estadístico de prueba Kolmogorov-Smirnov, las subvariables del IMC conocimiento de la organización, liderazgo, nivel grupal, nivel individual, nivel organizacional y resistencia evidencian tendencia a un comportamiento normal; las demás subvariables - adaptabilidad, aceptación, comunicación, cultura de cambio, gestión del cambio, participación/integración, proyección y desarrollo del cambio y trabajo en equipopresentan distribuciones sesgadas. En términos generales, las puntuaciones de las pruebas del IMC tienden a promedios cercanos o incluso superiores a tres, y sesgos negativos, es decir, tendencia a obtenerse puntuaciones altas.

Tabla 3. Estadísticos descriptivos cambio organizacional

\begin{tabular}{|c|c|c|c|c|}
\hline $\begin{array}{c}\text { Cambio } \\
\text { organizacional }\end{array}$ & Media & Desv. Típ. & $\begin{array}{l}\text { Test Kolmogorov- } \\
\text { Smirnov (Sig.) }\end{array}$ & Decisión \\
\hline Adaptabilidad & 2,9985 &, 55325 & .006 & Rechazar $\mathrm{H}_{\mathrm{o}}$ \\
\hline Aceptación & 2,9671 & ,42258 & .038 & Rechazar $\mathrm{H}_{\mathrm{o}}$ \\
\hline Comunicación & 3,0460 &, 56914 & .018 & Rechazar $\mathrm{H}_{\mathrm{o}}$ \\
\hline $\begin{array}{l}\text { Conocimiento de la } \\
\text { organización }\end{array}$ & 2,9025 &, 74527 & .102 & Retener $\mathrm{H}_{\mathrm{o}}$ \\
\hline Cultura de cambio & 2,7233 & ,79569 & .000 & Rechazar $\mathrm{H}_{\mathrm{o}}$ \\
\hline $\begin{array}{l}\text { Gestión del cambio } \\
\text { (Factor de segundo } \\
\text { Orden) }\end{array}$ & 3,1612 &, 50804 & .021 & Rechazar $\mathrm{H}_{\mathrm{o}}$ \\
\hline Liderazgo & 3,1457 &, 59210 & .052 & Retener $\mathrm{H}_{\mathrm{o}}$ \\
\hline Nivel grupal & 3,0317 & ,48285 & .216 & Retener $\mathrm{H}_{\mathrm{o}}$ \\
\hline Nivel individual & 3,0791 &, 50207 & .170 & Retener $\mathrm{H}_{\mathrm{o}}$ \\
\hline Nivel organizacional & 2,8369 & ,34097 & .639 & Retener $\mathrm{H}_{\mathrm{o}}$ \\
\hline $\begin{array}{l}\text { Participación } \\
\text { integración }\end{array}$ & 3,1535 & ,60733 & .042 & Rechazar $\mathrm{H}_{\mathrm{o}}$ \\
\hline $\begin{array}{c}\text { Proyección y desarrollo } \\
\text { del cambio (segundo } \\
\text { orden) }\end{array}$ & 2,9717 &, 57102 & .018 & Rechazar $\mathrm{H}_{\mathrm{o}}$ \\
\hline Resistencia al cambio & & ,61504 & .838 & Retener $\mathrm{H}_{\mathrm{o}}$ \\
\hline Trabajo en equipo & 2,8625 & ,64879 & .001 & Rechazar $\mathrm{H}_{\mathrm{o}}$ \\
\hline
\end{tabular}

Fuente: Elaboración propia. 
Mónica García Rubiano, Carlos Forero Aponte

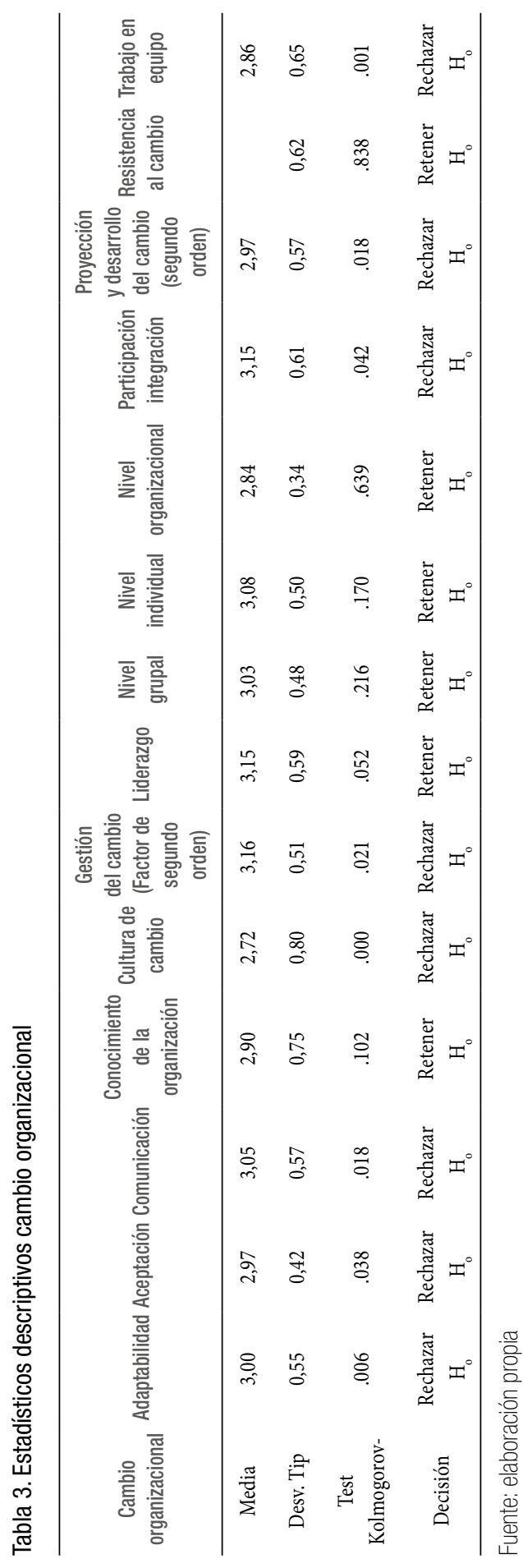


La información del comportamiento de las distribuciones de las subvariables de calidad de vida laboral es presentada en la tabla 4; los resultados de la prueba Kolmogorov-Smirnov indican que las subvariables compensación y beneficios, condiciones del ambiente y del trabajo, desarrollo y seguridad laboral y equilibrio laboral, no se distribuyen normalmente. Dichas subvariables presentan tendencia a curtosis de tipo platicúrtico, evidenciando distribuciones heterogéneas, lo cual implica una alta dispersión en los puntos de vista de los trabajadores respecto a las condiciones de retribución, garantía, la sensación de seguridad, entre otros factores en la organización.

En la tabla 4, se observa el comportamiento de las distribuciones de las subvariables naturaleza de la tarea, democracia organizacional, derechos fundamentales e impacto social, que a pesar de mostrar tendencias a unas puntuaciones por encima del promedio, tienen características de normalidad; estas subvariables comportan evidencias de ser distribuciones homogéneas con curtosis de tipo platicúrtico.

Tabla 4. Estadísticos descriptivos calidad de vida laboral

\begin{tabular}{ccccc}
\hline Calidad de vida & Media & Desv. típ. & $\begin{array}{c}\text { Test Kolmogorov- } \\
\text { Smirnov (Sig.) }\end{array}$ & Decisión \\
\hline $\begin{array}{c}\text { Compensación y beneficios } \\
\begin{array}{c}\text { Condiciones del ambiente y } \\
\text { del trabajo }\end{array}\end{array}$ & 13.4700 & 3.46251 & .021 & Rechazar $\mathrm{H}_{\mathrm{o}}$ \\
Naturaleza de la tarea & 17,9700 & 3,83618 & .039 & Rechazar $\mathrm{H}_{\mathrm{o}}$ \\
Desarrollo y seguridad & 18,3100 & 3,10651 & .069 & Retener $\mathrm{H}_{\mathrm{o}}$ \\
$\quad \begin{array}{c}\text { laboral } \\
\text { Democracia organizacional }\end{array}$ & 14,5100 & 2,96271 & .019 & Rechazar $\mathrm{H}_{\mathrm{o}}$ \\
Derechos fundamentales & 12,0200 & 2,41201 & .336 & Retener $\mathrm{H}_{\mathrm{o}}$ \\
Equilibrio laboral & 11,1100 & 2,51418 & .125 & Retener $\mathrm{H}_{\mathrm{o}}$ \\
Impacto social & 17,7000 & 3,46556 & .007 & Rechazar $\mathrm{H}_{\mathrm{o}}$ \\
\hline
\end{tabular}

Fuente: Elaboración propia.

En la tabla 5 se presenta la información del comportamiento de las distribuciones de los estadísticos descriptivos de la variable contrato psicológico; las subvariables contrato psicológico balanceado, desarrollo profesional, mercado interno, contrato psicológico relacional, lealtad, estabilidad, contrato psicológico transaccional, contrato psicológico transaccional estrecho, incertidumbre y no confía, tienden a un comportamiento normal y presentan tendencia a curtosis de tipo platicúrtico, lo que indica que se presentan distribuciones heterogéneas. 
Tabla 5. Estadísticos descriptivos contrato psicológico

\begin{tabular}{|c|c|c|c|c|}
\hline Contrato psicológico & Media & Desv. típ. & $\begin{array}{l}\text { Test Kolmogorov- } \\
\text { Smirnov (Sig.) }\end{array}$ & Decisión \\
\hline $\begin{array}{l}\text { Contrato psicológico } \\
\text { balanceado }\end{array}$ & 44,3200 & 10,56856 & .238 & Retener $\mathrm{H}_{\mathrm{o}}$ \\
\hline Empleabilidad externa & 13,4100 & 3,67656 & .115 & Retener $\mathrm{H}_{\mathrm{o}}$ \\
\hline $\begin{array}{l}\text { Requerimiento de rendición } \\
\text { dinámico }\end{array}$ & 17,1700 & 4,06278 & .011 & Rechazar $\mathrm{H}_{\mathrm{o}}$ \\
\hline $\begin{array}{l}\text { Desarrollo profesional } \\
\text { mercado interno }\end{array}$ & 13,7400 & 3,31394 & .193 & Retener $\mathrm{H}_{\mathrm{o}}$ \\
\hline $\begin{array}{l}\text { Contrato psicológico } \\
\text { relacional }\end{array}$ & 27,8000 & 6,94277 & .127 & Retener $\mathrm{H}_{\mathrm{o}}$ \\
\hline Lealtad & 17,6100 & 4,39673 & .051 & Retener $\mathrm{H}_{\mathrm{o}}$ \\
\hline Estabilidad & 10,1900 & 2,94630 & .054 & Retener $\mathrm{H}_{\mathrm{o}}$ \\
\hline $\begin{array}{l}\text { Contrato psicológico } \\
\text { transaccional }\end{array}$ & 27,3200 & 6,17077 & .212 & Retener $\mathrm{H}_{\mathrm{o}}$ \\
\hline $\begin{array}{l}\text { Contrato psicológico } \\
\text { transaccional estrecho }\end{array}$ & 13,6100 & 3,25327 & .119 & Retener $\mathrm{H}_{\mathrm{o}}$ \\
\hline $\begin{array}{l}\text { Contrato psicológico } \\
\text { transaccional corto plazo }\end{array}$ & 13,7100 & 3,67985 & .047 & Rechazar $\mathrm{H}_{\mathrm{o}}$ \\
\hline $\begin{array}{l}\text { Contrato psicológico } \\
\text { transicional }\end{array}$ & 36,9300 & 8,61084 & .339 & Retener $\mathrm{H}_{\mathrm{o}}$ \\
\hline Erosión & 13,2900 & 3,40319 & .099 & Retener $\mathrm{H}_{\mathrm{o}}$ \\
\hline Incertidumbre & 13,7400 & 3,64766 & .087 & Retener $\mathrm{H}_{\mathrm{o}}$ \\
\hline No confía & 10,0000 & 2,59119 & .147 & Retener $\mathrm{H}_{0}$ \\
\hline
\end{tabular}

Fuente: Elaboración propia.

Posteriormente se adelantó el análisis de las correlaciones entre las subvariables de la disposición ante el cambio organizacional con las subvariables de calidad de vida laboral y contrato psicológico. Respecto a las subvariables de cambio organizacional, es importante tener en cuenta que están constituidas por tres elementos: 1) variables simples, 2) factores de cambio de primer y 3 ) factores de segundo orden, y por tanto se presentan los análisis para cada aspecto.

Se encontraron correlaciones positivas y significativas entre la subvariable de cambio adaptabilidad con las subvariables compensación y beneficios ( $\mathrm{Rho}=0,320 ; p<0,01)$; también se encontró correlación positiva y significativa entre la subvariable aceptación naturaleza de la tarea $(\mathrm{Rho}=0,275 ; p<0,006)$.

En cuanto a la subvariable liderazgo, esta correlacionó positiva y significativamente con las subvariables compensación y beneficios ( $\mathrm{Rho}=0,366 ; p<0,00)$, condiciones del ambiente de trabajo (Rho $=0,324 ; p<0,01)$, naturaleza de la tarea (Rho $=$ 0,$420 ; p<0,00$ ), derechos fundamentales ( $R h o=0,339 ; p<0,01$ ) y equilibrio laboral 
$($ Rho $=0,247 ; p<0,013)$. La subvariable participación y organización correlacionó positiva y significativamente con las subvariables naturaleza de la tarea $(\mathrm{Rho}=0,358$; $p<0,00)$ y derechos fundamentales $(\mathrm{Rho}=0,274 ; p<0,00$ ). Por último, las subvariables comunicación, conocimiento de la organización, cultura de cambio y trabajo en equipo correlacionaron significativamente con todas las subvariables de calidad de vida laboral (ver tabla 6).

En la tabla 7 se presentan los factores de cambio de primer orden que correlacionaron de la siguiente manera: la subvariable nivel individual correlacionó positiva y significativamente con las subvariables compensación y beneficios ( $\mathrm{Rho}=0,423 ; p<0,00$ ) y naturaleza de la tarea $(\mathrm{Rho}=0,383 ; p<0,00)$. La subvariable nivel organizacional correlacionó de manera significativa con las subvariables condiciones del ambiente de trabajo ( $\mathrm{Rho}=0,378 ; p<0,00$ ), y la subvariable nivel grupal correlacionó positiva y significativamente al nivel 0,01 con todas las subvariables de calidad de vida laboral Respecto a los factores de segundo orden, la subvariable gestión del cambio correlacionó significativamente con las subvariables compensación y beneficios ( $\mathrm{Rho}=0,316$; $p<0,01$ ), condiciones del ambiente de trabajo ( $R h o=0,353 ; p<0,00$ ), naturaleza de la tarea $(\mathrm{Rho}=0,461 ; p<0,00)$, derechos fundamentales $(\mathrm{Rho}=0,356 ; p<0,00)$ e impacto social ( $R h o=0,278 ; p<0,005)$, y por último la subvariable proyección y desarrollo del cambio correlacionó positiva y significativamente con todas las subvariables de calidad de vida laboral.

En la tabla 8 se presentan las correlaciones entre las variables simples: la subvariable de cambio aceptación correlacionó positiva y significativamente con las subvariables contrato psicológico balanceado ( $\mathrm{Rho}=0,217 ; p<0,03$ ). La subvariable participación e integración correlacionó positiva y significativamente con las subvariables empleabilidad externa (Rho $=0,328 ; p<0,01)$, estabilidad ( Rho $=0,307 ; p<0,02)$, contrato psicológico transaccional corto plazo $(\mathrm{Rho}=0,249 ; p<0,12)$ e incertidumbre $($ Rho $=0,333 ; p<0,001)$.

Las subvariables conocimiento de la organización, liderazgo y trabajo en equipo correlacionaron positiva y significativamente con la mayoría de las subvariables de contrato psicológico, quedando de la siguiente manera: la subvariable conocimiento de la organización correlacionó positiva y significativamente con las subvariables contrato psicológico balanceado $(\mathrm{Rho}=0,469 ; p<0,00)$, empleabilidad externa $(\mathrm{Rho}=0,471$; $p<0,00)$, requerimiento de rendición dinámico $(\mathrm{Rho}=0,484 ; p<0,00)$, desarrollo profesional mercado interno ( $\mathrm{Rho}=0,358 ; p<0,00$ ), contrato psicológico relacional $(\mathrm{Rho}=0,435 ; p<0,00)$, lealtad $(\mathrm{Rho}=0,407 ; p<0,00)$, estabilidad $(\mathrm{Rho}=0,428$; $p<0,00$ ), contrato psicológico transaccional (Rho $=0,337 ; p<0,01$ ), contrato 


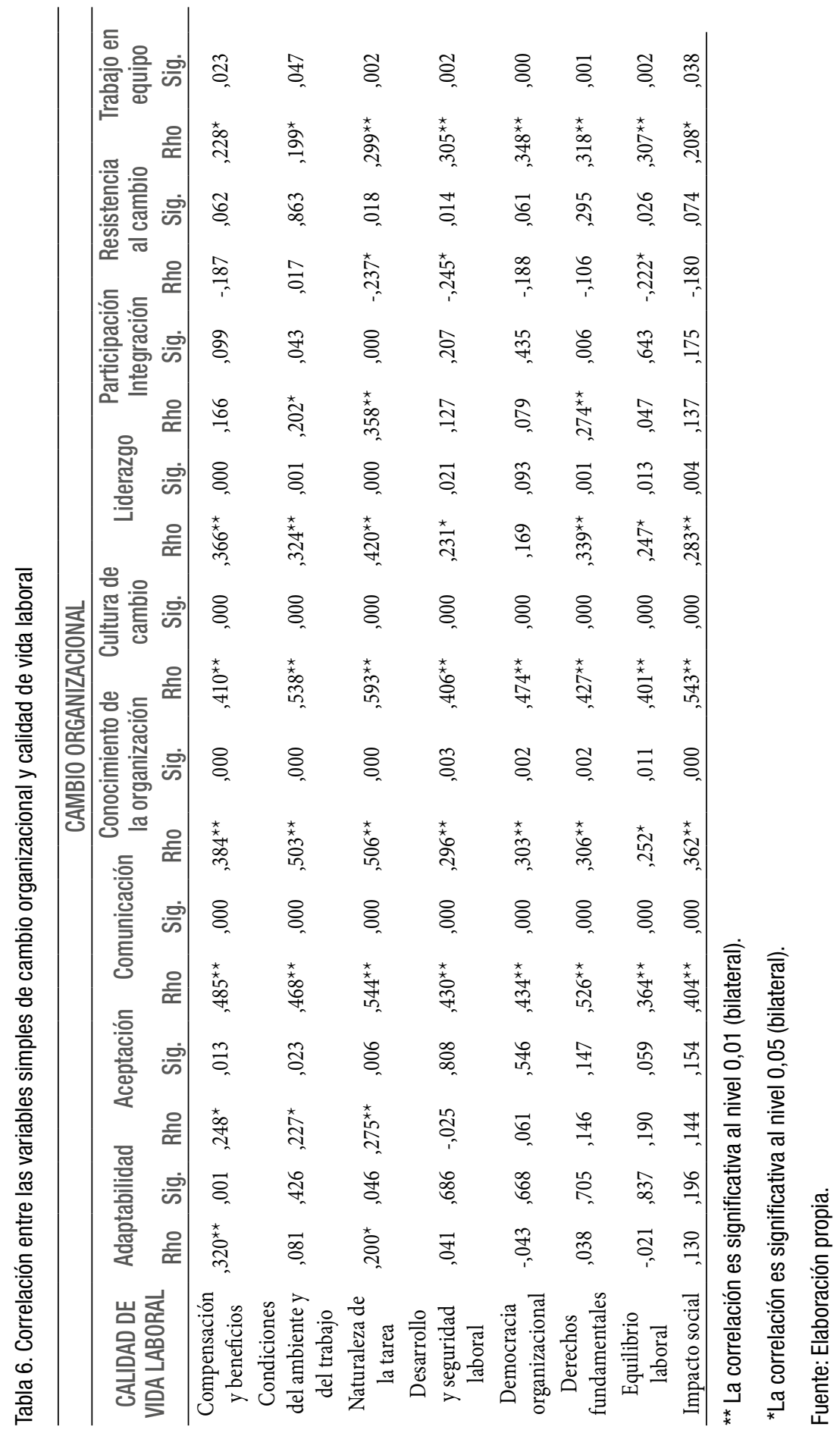


Relación entre calidad de vida laboral, contrato psicológico y cambio organizacional...

Tabla 7. Correlación entre los factores de cambio de primer y segundo orden y calidad de vida laboral

\begin{tabular}{|c|c|c|c|c|c|c|c|c|c|c|}
\hline \multicolumn{11}{|c|}{ CAMBIO ORGANIZACIONAL } \\
\hline \multirow[t]{2}{*}{$\begin{array}{l}\text { CALIDAD DE VIDA } \\
\text { LABORAL }\end{array}$} & \multicolumn{2}{|c|}{ Nivel Grupal } & \multicolumn{2}{|c|}{$\begin{array}{c}\text { Nivel } \\
\text { Individual }\end{array}$} & \multicolumn{2}{|c|}{$\begin{array}{c}\text { Nivel } \\
\text { Organizacional }\end{array}$} & \multicolumn{2}{|c|}{$\begin{array}{l}\text { Gestión del } \\
\text { cambio }\end{array}$} & \multicolumn{2}{|c|}{$\begin{array}{l}\text { Proyección y } \\
\text { desarrollo del } \\
\text { cambio }\end{array}$} \\
\hline & Rho & Sig. & Rho & Sig. & Rho & Sig. & Rho & Sig. & Rho & Sig. \\
\hline Compensación y beneficios &, $412^{* *}$ &, 000 &, $423^{* *}$ &, 000 & 166 & ,098 &, $316^{* *}$ &, 001 & $466^{* *}$ &, 000 \\
\hline $\begin{array}{c}\text { Condiciones del ambiente y } \\
\text { del trabajo }\end{array}$ &, $382^{* *}$ &, 000 &, $265^{* *}$ & ,008 &, $378^{* *}$ & 000 &, $353^{* *}$ &, 000 &, $387^{* *}$ &, 000 \\
\hline Naturaleza de la Tarea &, $523^{* *}$ &, 000 &, $383^{* *}$ &, 000 & $230^{*}$ & 021 &, $461^{* *}$ &, 000 &, $503^{* *}$ &, 000 \\
\hline $\begin{array}{c}\text { Desarrollo y Seguridad } \\
\text { Laboral }\end{array}$ &, $355^{* *}$ &, 000 & ,172 & ,088 & 003 & ,977 & , 193 &, 054 &, $427^{* *}$ &, 000 \\
\hline Democracia Organizacional &, $354^{* *}$ &, 000 & ,082 & ,418 & ,091 & ,370 & 148 &, 142 & $378^{* *}$ &, 000 \\
\hline Derechos Fundamentales &, $480^{* *}$ &, 000 &, $246^{*}$ &, 014 & 164 & ,104 &, $356^{* *}$ &, 000 &, $477^{* *}$ &, 000 \\
\hline Equilibrio Laboral &, $308^{* *}$ &, 002 & 159 & ,113 & ,081 & ,425 & , 187 &, 062 &, $294^{* *}$ &, 003 \\
\hline Impacto social &, $320^{* *}$ &, 001 &, $267^{* *}$ &, 007 & , 169 & ,094 &, $278^{* *}$ &, 005 &, $322^{* *}$ &, 001 \\
\hline
\end{tabular}

** La correlación es significativa al nivel 0,01 (bilateral).

*La correlación es significativa al nivel 0,05 (bilateral).

Fuente: Elaboración propia.

psicológico transaccional corto plazo ( $\mathrm{Rho}=0,409 ; p<0,01)$, contrato psicológico transicional (Rho $=0,378 ; p<0,00)$ e incertidumbre $(\mathrm{Rho}=0,481 ; p<0,00)$.

La subvariable liderazgo correlacionó positiva y significativamente con las subvariables contrato psicológico balanceado ( $\mathrm{Rho}=0,363 ; p<0,00$ ), empleabilidad externa $(\mathrm{Rho}=0,343 ; p<0,00)$, requerimiento de rendición dinámico $(\mathrm{Rho}=0,395 ; p<0,00)$, desarrollo profesional mercado interno ( $\mathrm{Rho}=0,277 ; p<0,05$ ), contrato psicológico relacional ( $\mathrm{Rho}=0,374 ; p<0,00)$, lealtad $(\mathrm{Rho}=0,367 ; p<0,00)$, estabilidad $(\mathrm{Rho}=0,308 ; p<0,00)$, contrato psicológico transaccional corto plazo $(\mathrm{Rho}=0,316$; $p<0,01$ ), contrato psicológico transicional ( $\mathrm{Rho}=0,280 ; p<0,05)$ e incertidumbre $($ Rho $=0,347 ; p<0,00)$.

La subvariable trabajo en equipo correlacionó positiva y significativamente con las subvariables contrato psicológico balanceado ( $\mathrm{Rho}=0,425 ; p<0,00$ ), empleabilidad externa ( $\mathrm{Rho}=0,402 ; p<0,00)$, requerimiento de rendición dinámico $(\mathrm{Rho}=0,363$; $p<0,00$ ), desarrollo profesional mercado interno ( $\mathrm{Rho}=0,464 ; p<0,00$ ), contrato psicológico relacional (Rho $=0,338 ; p<0,01)$, lealtad ( $\mathrm{Rho}=0,341 ; p<0,01)$, estabilidad (Rho $=0,326 ; p<0,01)$, contrato psicológico transicional $(\mathrm{Rho}=0,317$; $p<0,01)$, incertidumbre ( Rho $=0,354 ; p<0,00)$ y no confía $(\mathrm{Rho}=0,310 ; p<0,02)$, Por ultimo las subvariables cultura de cambio y comunicación correlacionaron significativamente con todas las subvariables de contrato psicológico. 


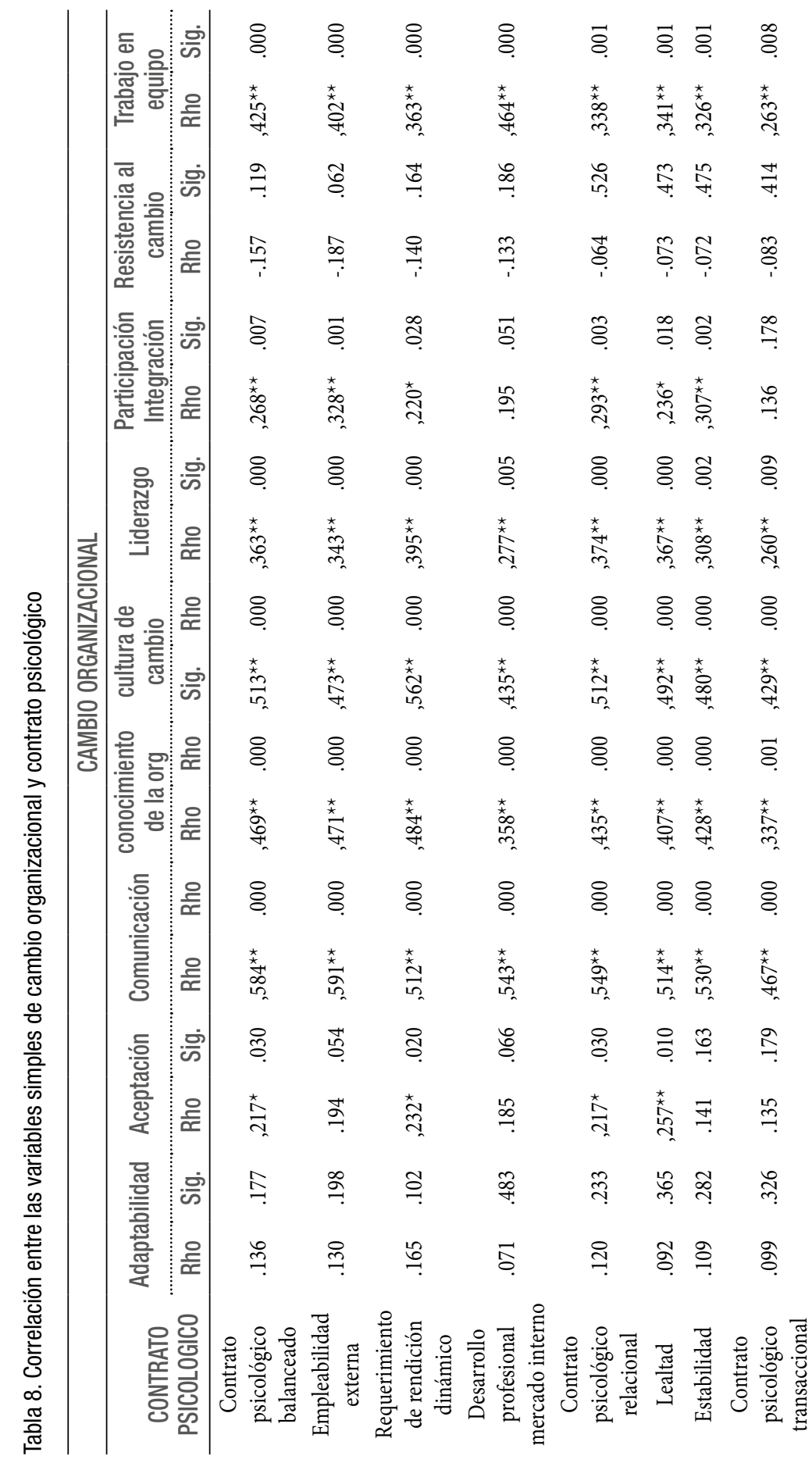


Relación entre calidad de vida laboral, contrato psicológico y cambio organizacional...

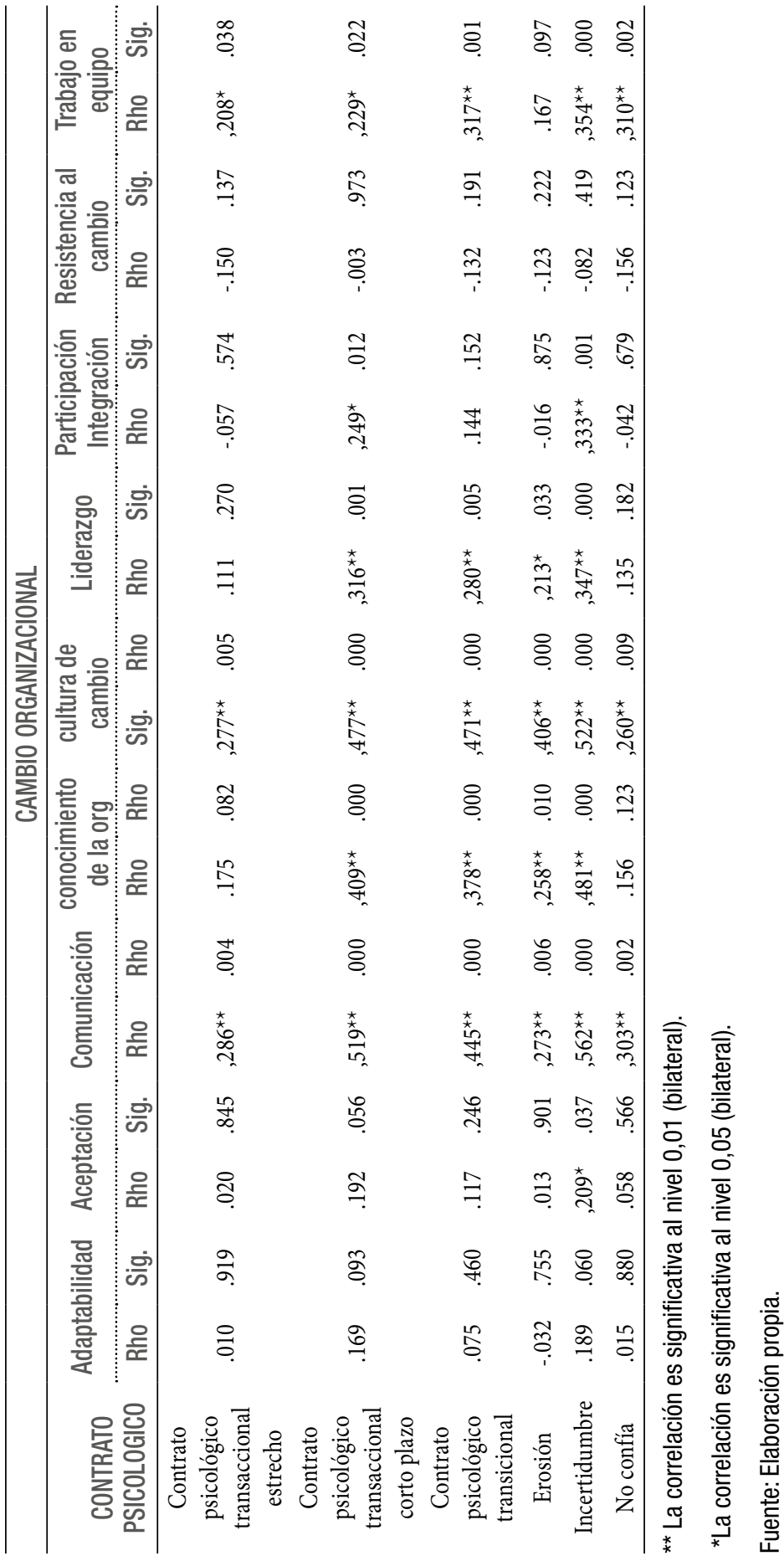


Respecto a los factores de cambio, los de primer orden correlacionaron de la siguiente forma: la subvariable nivel grupal correlacionó con las subvariables contrato psicológico balanceado $(\mathrm{Rho}=0,554 ; p<0,00)$, empleabilidad externa $(\mathrm{Rho}=0,577$; $p<0,00)$, requerimiento de rendición dinámico $(\mathrm{Rho}=0,475 ; p<0,00)$, desarrollo profesional mercado interno ( $\mathrm{Rho}=0,518 ; p<0,00$ ), contrato psicológico relacional $(\mathrm{Rho}=0,504 ; p<0,00)$, lealtad $(\mathrm{Rho}=0,459 ; p<0,00)$, estabilidad ( $\mathrm{Rho}=0,502$; $p<0,00$ ), contrato psicológico transaccional ( $\mathrm{Rho}=0,383$; $p<0,00$ ), contrato psicológico transaccional corto plazo ( $\mathrm{Rho}=0,439 ; p<0,00)$, contrato psicológico transicional $(\mathrm{Rho}=0,388 ; p<0,00)$ e incertidumbre $(\mathrm{Rho}=0,545 ; p<0,00)$.

La subvariable nivel individual correlacionó significativamente con las subvariables contrato psicológico balanceado ( $\mathrm{Rho}=0,314 ; p<0,001$ ), empleabilidad externa $(\mathrm{Rho}=0,304 ; p<0,002)$, requerimiento de rendición dinámico $(\mathrm{Rho}=0,350$; $p<0,00)$, contrato psicológico relacional $(\mathrm{Rho}=0,318 ; p<0,001)$, lealtad $(\mathrm{Rho}=0,296$; $p<0,003)$ e incertidumbre ( $\mathrm{Rho}=0,337 ; p<0,001$ ), y la subvariable nivel organizacional también logró correlacionar significativamente con las subvariables requerimiento de rendición dinámico ( $\mathrm{Rho}=0,283 ; p<0,004)$, contrato psicológico relacional $(\mathrm{Rho}=0,304 ; p<0,002)$, lealtad $(\mathrm{Rho}=0,307 ; p<0,002)$, contrato psicológico transaccional corto plazo $(\mathrm{Rho}=0,325 ; p<0,001)$ e incertidumbre $(\mathrm{Rho}=0,297$; $p<0,003)$.

De los factores de segundo orden, la primer subvariable gestión del cambio correlacionó significativamente con las subvariables contrato psicológico balanceado $(\mathrm{Rho}=0,373 ; p<0,00)$, empleabilidad externa $(\mathrm{Rho}=0,360 ; p<0,00)$, requerimiento de rendición dinámico $(\mathrm{Rho}=0,383 ; p<0,00)$, desarrollo profesional mercado interno $(\mathrm{Rho}=0,287 ; p<0,004)$, contrato psicológico relacional $(\mathrm{Rho}=0,404 ; p<0,00)$, lealtad $(\mathrm{Rho}=0,376 ; p<0,00)$, estabilidad ( $\mathrm{Rho}=0,363 ; p<0,00)$, contrato psicológico transaccional corto plazo $(\mathrm{Rho}=0,356 ; p<0,00)$ e incertidumbre $(\mathrm{Rho}=0,394$; $p<0,00)$. La segunda subvariable, proyección y desarrollo del cambio, correlacionó significativamente al nivel 0,01 con todas las subvariables de contrato psicológico (ver tabla 9).

Una vez expuestas las correlaciones entre las subvariables, a continuación se encuentran correlaciones aún más específicas que permiten identificar la relación del contrato transaccional y relacional. En primer lugar, se muestra que la subvariable contrato transaccional correlacionó significativamente ( $\mathrm{Rho}=0,364 ; p<0,00)$, al igual que la subvariable contrato relacional $(\mathrm{Rho}=0,481 ; p<0,00)$; a partir de lo anterior se evidencia que estas dos subvariables pueden determinar la disposición al cambio organizacional. 
Relación entre calidad de vida laboral, contrato psicológico y cambio organizacional...

Tabla 9. Correlación entre los factores de cambio de primer y segundo orden y contrato psicológico

\begin{tabular}{|c|c|c|c|c|c|}
\hline \multicolumn{6}{|c|}{ CAMBIO ORGANIZACIONAL } \\
\hline CONTRATO PSICOLOGICO & Nivel Grupal & $\begin{array}{c}\text { Nivel } \\
\text { Individual }\end{array}$ & $\begin{array}{c}\text { Nivel } \\
\text { Organizacional }\end{array}$ & $\begin{array}{l}\text { Gestión } \\
\text { del cambio }\end{array}$ & $\begin{array}{l}\text { Proyección y } \\
\text { desarrollo del } \\
\text { cambio }\end{array}$ \\
\hline & Rho & Sig. & Rho & Rho & Rho \\
\hline $\begin{array}{l}\text { Contrato psicológico } \\
\text { balanceado }\end{array}$ &, $554^{\star *}$ & .000 &, $314^{* *}$ & .001 &, $245^{\star}$ \\
\hline Empleabilidad externa &, $577^{* *}$ & .000 &, $304^{* *}$ & .002 &, $217^{\star}$ \\
\hline $\begin{array}{l}\text { Requerimiento de rendición } \\
\text { dinámico }\end{array}$ &, $475^{\star *}$ & .000 &, $350^{* *}$ & .000 &, $283^{* *}$ \\
\hline $\begin{array}{l}\text { Desarrollo profesional } \\
\text { mercado interno }\end{array}$ &, $518^{\star *}$ & .000 &, $217^{\star}$ & .030 & .183 \\
\hline $\begin{array}{l}\text { Contrato psicológico } \\
\text { relacional }\end{array}$ &, $504^{\star *}$ & .000 &, $318^{* *}$ & .001 &, $304^{* *}$ \\
\hline Lealtad &, $459^{* *}$ & .000 &, $296^{* *}$ & .003 &, $307^{* *}$ \\
\hline Estabilidad &, $502^{* *}$ & .000 &, $268^{* *}$ & .007 &, $249^{*}$ \\
\hline $\begin{array}{l}\text { Contrato psicológico } \\
\text { transaccional }\end{array}$ &, $383^{* *}$ & .000 &, $230^{*}$ & .021 &, $227^{*}$ \\
\hline $\begin{array}{l}\text { Contrato psicológico } \\
\text { transaccional estrecho }\end{array}$ &, $197^{\star}$ & .050 & .080 & .430 & .057 \\
\hline $\begin{array}{l}\text { Contrato psicológico } \\
\text { transaccional corto plazo }\end{array}$ &, $439^{* *}$ & .000 &, $308^{* *}$ & .002 &, $325^{* *}$ \\
\hline $\begin{array}{l}\text { Contrato psicológico } \\
\text { transicional }\end{array}$ &, $388^{* *}$ & .000 &, $231^{*}$ & .021 &, $213^{*}$ \\
\hline Erosión & .177 & .078 & .125 & .214 & .139 \\
\hline Incertidumbre &, $545^{* *}$ & .000 &, $337^{* *}$ & .001 &, $297^{* *}$ \\
\hline No confía &, $238^{*}$ & .018 & .105 & .300 & .064 \\
\hline
\end{tabular}

** La correlación es significativa al nivel 0,01 (bilateral).

*La correlación es significativa al nivel 0,05 (bilateral).

Fuente: Elaboración propia.

Otra correlación significativa es la de la subvariable condiciones de la calidad de vida laboral (Rho $=0,444 ; p<0,00$ ), lo que indica que dicha subvariable es determinante al momento de implementar un cambio organizacional (ver tabla 10).

Tabla 10. Correlaciones entre contrato transaccional/relacional y las condiciones de la calidad de vida laboral

\begin{tabular}{cll}
\hline & Rho & Sig. \\
\hline Contrato transaccional &, $364^{* *}$ & .000 \\
Contrato relacional &, $481^{* *}$ & .000 \\
Condiciones de la calidad de vida laboral &, $444^{* *}$ & .000 \\
\hline
\end{tabular}

Fuente: Elaboración propia. 
Expuestas las correlaciones, se da paso al análisis de las regresiones. En la figura 1 se observa el peso de las regresiones de las variables de estudio, esto con el fin de dar cuenta del objetivo general de esta investigación, que consiste en determinar las condiciones de calidad de vida laboral y la percepción del contrato psicológico como variables relacionadas con el cambio organizacional

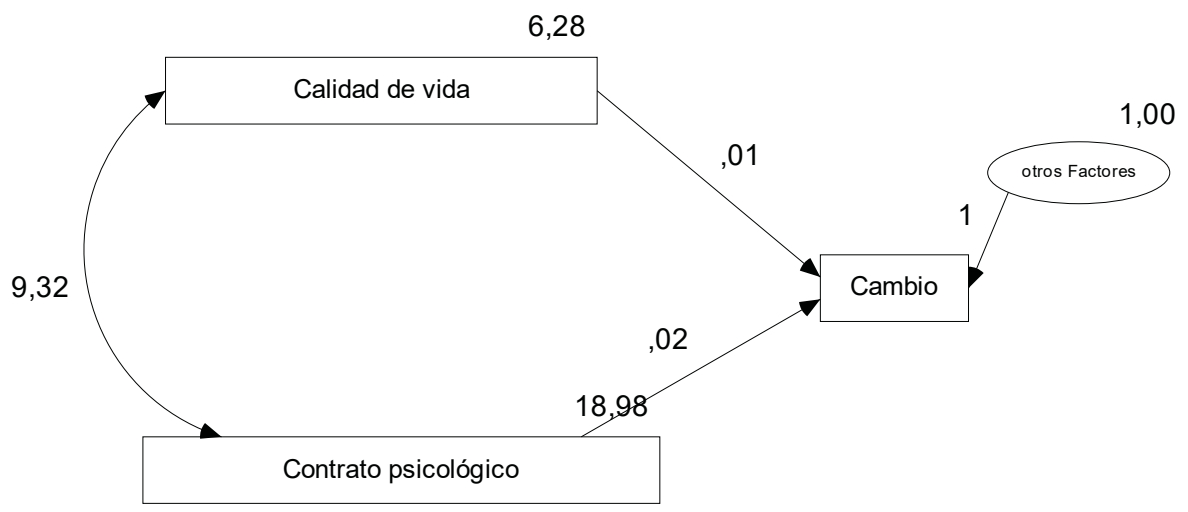

Figura 1. Representación gráfica de los resultados obtenidos en el modelo de ecuaciones estructurales estandarizadas. Fuente: Elaboración propia.

En la tabla 11 se evidencia que los datos arrojaron un peso de regresión bajo entre cambio organizacional y calidad de vida laboral y cambio organizacional y contrato psicológico; también se observa que la calidad de vida tiene un mayor potencial explicativo que el contrato psicológico. Sin embargo, se evidencia una covariación significativa entre contrato psicológico y calidad de vida laboral, lo que permite suponer que hay causalidad entre las dos variables.

Tabla 11. Regresión entre las variables calidad de vida laboral y contrato psicológico con la variable cambio organizacional

\begin{tabular}{ccccccc}
\hline & & & Estimado & Error estándar & Relación crítica & Probabilidad \\
\hline Cambio & $<---$ & Calidad de vida &, 008 &, 077 &, 105 &, 916 \\
Cambio & $<---$ & Contrato psicológico &, 024 &, 044 &, 538 &, 590 \\
\hline
\end{tabular}

Fuente: Elaboración propia.

Otro aspecto evaluado fue la covariancia entre las variables de estudio que se evidencian en la tabla 12; se encontró que existe una relación significativa a nivel individual y no en conjunto. A pesar de que el foco de la investigación apuntaba a la relación entre las variables calidad de vida laboral con contrato psicológico, se encontró la covarianza significativa existente entre estas últimas dos variables, lo cual implica que la calidad de vida laboral tiene un efecto en el contrato psicológico y viceversa. 
Relación entre calidad de vida laboral, contrato psicológico y cambio organizacional...

Tabla 12. Covarianza entre las variables calidad de vida laboral y contrato psicológico

\begin{tabular}{ccccccc}
\hline & & & Estimado & Error Estándar & Critical. Ratio & Probabilidad \\
\hline Calidad de vida & $<->$ & Contrato psicológico & 9,324 & 1,443 & 6,463 & \multirow{*}{***}{} \\
\hline
\end{tabular}

Fuente: Elaboración propia.

\section{Discusión}

Este estudio tuvo como propósito determinar las condiciones de la calidad de vida laboral y la percepción del contrato psicológico como facilitadores del cambio organizacional en diferentes empresas de Bogotá. Para responder al primer objetivo, se analizó la variable cambio organizacional, con la intención de identificar la disposición de los trabajadores frente a este cambio; los resultados evidencian una disposición favorable en las subvariables aceptación y resistencia al cambio, que son determinantes en este proceso. El componente actitudinal desempeña un papel primordial sobre estas dos subvariables, puesto que los empleados que poseen una fuerte y positiva actitud hacia el cambio, probablemente apoyen, acepten y faciliten la iniciativa de cambio que se está aplicando, como se soporta en los resultados (Bohner \& Dickel, 2011; García \& Forero, 2011).

En el caso en que los trabajadores tengan una actitud negativa hacia el cambio, son más propensos a presentar resistencia y conductas de desprecio, frustración y se podría sabotear la iniciativa organizacional. Es fundamental tener en cuenta el surgimiento de las distintas actitudes y comportamientos de los trabajadores que se encuentran involucrados en un proceso de cambio; al respecto, Zimmermann (2000) establece que la actitud frente al cambio se puede clasificar en tres grupos: los que lo ven como positivo, los indiferentes y los que lo ven como algo negativo. En esta investigación el grupo más grande fue el de los que aprueban el cambio, por ende la resistencia no se hace evidente, en otras palabras, se establece que los trabajadores de las tres empresas que fueron objeto de estudio están dispuestos a asumir el proceso de cambio dentro de sus organizaciones.

En cuanto al segundo objetivo específico, que era identificar las diferentes condiciones de calidad de vida laboral en los trabajadores, se encontraron respuestas positivas frente al sistema de compensación y beneficios en las tres empresas, lo que denota que los trabajadores tienen un alto interés en el reconocimiento que se les otorga por la realización de sus tareas; puesto que es natural que las personas en la actualidad demanden cada vez más contraprestaciones adicionales a las de un salario fijo que esté acorde con su estilo de vida, además de que existen deseos que van más allá de la 
superación profesional, el empleado espera recibir de la organización un valor agregado, ya sea motivacional o monetario (Mejbel et ál., 2013) .

Respecto al desarrollo/seguridad laboral y al equilibrio laboral percibidos por los trabajadores, se logra evidenciar que tienen una perspectiva positiva respecto a ambas, lo cual se puede explicar por la existencia de condiciones en el escenario laboral que favorecen la satisfacción laboral en estas empresas, aspectos de retribución adecuada, seguridad laboral y oportunidades de desarrollo en el trabajo, factores que promueven las percepciones favorables de los empleados con respecto a su calidad de vida dentro de la organización. Lo anterior también podría explicarse a través de los factores de garantía y estabilidad que les proveen las organizaciones, así, si el empleado se siente seguro y encuentra estabilidad, no buscaría otro empleo (a menos de que tenga expectativas o proyecciones más altas) puesto que la demanda de ofertas laborales cada vez es más competitiva; según Gómez-Rada y Ponce de León (2010), cuando las personas tienen un largo periodo de desempleo o inestabilidad laboral, tal como lo señalan Martínez, De Cuyper y De Witte (2010), se genera incertidumbre, que es percibida como inseguridad laboral

Es importante resaltar las variables sociodemográficas, puesto que se ha encontrado la correlación significativa que existe entre las variables salario, género, educación y experiencia con la satisfacción laboral. La edad ha sido identificada como un fuerte predictor de CVL, y se ha demostrado que los empleados de mayor edad tienden a desarrollar un mejor ajuste entre las necesidades personales y sus puestos de trabajo que los empleados más jóvenes (Oktug, 2013). También los empleados con mayor nivel educacional a menudo tienen expectativas más altas, por lo que son menos propensos a estar satisfechos con sus puestos de trabajo. En esta investigación se logró evidenciar lo contrario: la población que predominó en las tres empresas fueron los adultos jóvenes, el $31 \%$ con un nivel de educación técnico, probablemente este fenómeno se pueda sustentar a partir de las condiciones laborales que ofrecen las tres empresas para que sus empleados se mantengan satisfechos con independencia de su edad y nivel educacional.

Respecto al tercer objetivo específico, la identificación de los estilos de contrato psicológico, se evidenció que los contratos balanceado, transicional, relacional y transaccional presentan una tendencia favorable entre los empleados, sin importar el tipo de contrato que tuvieran; al parecer, predominan las expectativas y percepciones favorables (Janssens et ál., 2003).

La subvariable adaptabilidad no correlacionó significativamente con las variables de contrato psicológico; aunque no hay estudios que hagan énfasis en la relación de estas variables, es probable que cuando existe una ruptura del contrato psicológico 
se presenten dificultades en la adaptación de los trabajadores en la organización, y viceversa. En el mantenimiento de los contratos psicológicos, según Gracia et ál., (2006), si se afecta el contrato psicológico por algún cambio desarrollado por la organización, esta debe generar estrategias correctivas para que no se produzca un decremento en el desempeño que afecte a la organización ni al trabajador. En este sentido, Rousseau (1989) señala la importancia de los contratos psicológicos con los empleados en la medida en que estos se ven reflejados en la productividad y la adaptación de los trabajadores.

A diferencia de la subvariable adaptabilidad, las demás subvariables de cambio organizacional correlacionaron significativamente con la variable contrato psicológico, lo cual es coherente con la H2. Esta relación es confirmada en el estudio realizado por los autores (García-Rubiano \& Forero-Aponte, 2015), donde se evidenció la correlación de la mayoría de las subvariables de contrato psicológico con las variables de cambio y se concluyó que los trabajadores de las tres empresas manifiestan una disposición de favorabilidad frente a la relación entre cambio organizacional y contrato psicológico.

Respecto a la relación entre cambio organizacional y calidad de vida laboral, se identificó que ambas variables se correlacionan significativamente, en concordancia con la H1. Estos resultados son consistentes con los obtenidos por los autores (García \& Forero, 2014), quienes hallaron correlaciones significativas al 0,001 con todas las variables de cambio organizacional y las de calidad de vida, excepto las de resistencia al cambio. En la presente investigación esta subvariable, acompañada de otras como adaptabilidad, aceptación y participación e integración, no obtuvieron una correlación significativa con el resto de las subvariables, lo que sugiere que uno de los aspectos a resaltar es la importancia de garantizar la inclusión de los trabajadores en el proceso de cambio, pues en la medida en que ellos participen, la aceptación de y adaptación al cambio serán más sencillas y por ende tendrán mejor disposición para el cambio.

En relación con el análisis realizado a través del modelo de ecuaciones estructurales, las variables calidad de vida laboral y contrato psicológico presentan una covariación significativa, respondiendo a la H4. Según Giraldo, Peláez y Valencia (2013), la cercanía que existe entre el contrato psicológico y el bienestar laboral se debe a que el personal genera expectativas y creencias que no siempre son satisfechas por la organización, por lo que es importante detectar en qué convergen y en qué difieren estas de las prácticas de bienestar laboral que se gestan desde la organización. También se expone que el contrato psicológico ha cobrado gran importancia desde que las organizaciones han venido indagando por las creencias y expectativas que se construyen a 
través de las relaciones laborales, las cuales han resultado ser un elemento para comprender e intervenir de manera que se apunte al fortalecimiento de la satisfacción, sentido de pertenencia y calidad de vida del personal.

\section{Conclusiones}

A manera de conclusión, los resultados del trabajo muestran que las condiciones de la calidad de vida laboral y la percepción del contrato psicológico tienen una relación baja con el cambio organizacional (respondiendo a la H3); sin embargo, la calidad de vida laboral sí es un indicador importante para el desarrollo del cambio.

Con respecto a las dificultades presentadas, vale la pena mencionar, en primer lugar, la escasa información teórica y empírica que se encuentra de la relación entre variables; efectivamente existen diversas investigaciones e información de las variables a nivel individual, pero los estudios que documentan la relación entre variables son insuficientes. En segundo lugar, a partir de los resultados arrojados se detectó la posibilidad de que la prueba no esté discriminando los ítems de manera óptima, o tal vez la presencia de un fenómeno de deseabilidad social afectó los resultados, pues hubo tendencia a contestar los ítems de manera favorable, es decir, varias subvariables mostraron una distribución homogénea con curtosis leptocúrticas, lo que indica que probablemente los ítems que presentaron tendencias homogéneas no están apuntando al objetivo de la prueba.

En futuras investigaciones se propone la realización de estudios teóricos y empíricos más exhaustivos sobre la relación entre la variable cambio organizacional y las variables calidad de vida laboral y contrato psicológico. La importancia de esto radica en que esta información tendría un contenido valioso para las organizaciones que actualmente están cambiando por las exigencias tanto del ambiente interno como externo; lo ideal de esta relación de variables es proporcionar el conocimiento y las herramientas para facilitar el cambio y, asimismo, garantizar que este se presente de manera positiva en las diferentes organizaciones

\section{Referencias}

Acosta, C. (2002). Cuatro preguntas para iniciarse un cambio organizacional. Revista Colombiana de Psicología, 11, 9-24.

Bohner, G. \& Dickel, N. (2011). Attitudes and Attitude Change. Annual Review of Psychology, 62(1), 391-417. doi: 10.1146/annurev.psych.121208.131609

Drucker, P. (1996). La Sociedad Post Capitalista. Norma. 
Eagly, A. H., Chen, S., Chaiken, S. \& Shaw-Barnes, K. (1999). The impact of attitudes on memory: an affair to remembers. Psychological bulletin, 125(1), 64-89. http://dx.doi. org/10.1037/0033-2909.125.1.64

García, M. \& Forero, C. (2010). IMC - Instrumento de Medición de Cambio Organizacional. Manual Técnico. RH\&T. (Documento no publicado).

García, M., Rojas, M. \& Díaz, S. (2011). Relación entre el cambio organizacional y la actitud al cambio en trabajadores de una empresa de Bogotá. Diversitas Perspectivas en Psicología, $7(1), 125-142$.

García-Rubiano, M. \& Forero-Aponte, C. (2015). Contrato psicológico y cambio organizacional en una entidad perteneciente al sector terciario de la ciudad de Bogotá, Colombia. Revista de Investigación, Desarrollo e Innovación, 6(1), 15-28.

García, M. \& Forero, C. (2016). Calidad de vida laboral y la disposición al cambio organizacional en funcionarios de empresas de la ciudad de Bogotá - Colombia. Acta Colombiana de Psicología, 19(1), 79-90. doi: 10.14718/ ACP.2016.19.1.5

Giraldo, B., Peláez, K. \& Valencia, L. (2013). El contrato psicológico y su relación con el bienestar laboral. Universidad Católica de Pereira.

Gómez Rada, C. A. (2010). Diseño, construcción y validación de un instrumento que evalúa la calidad de vida la boral percibida en organizaciones colombianas, desde la teoría de respuesta al item. Psychologia. Avances de la Disciplina, 4(1), 113-124.

Gómez-Rada, C. \& Ponce de León, E. (2010). Modelo integrativo de la calidad de vida laboral percibida a partir de la inseguridad laboral, la jornada laboral y el salario, para hombres y mujeres trabajadores de empresas de la ciudad de Bogotá en diferentes rangos de edad. Psychologia: Avances de la Disciplina, 4(2), 113-129.

Gracia, F., Silla, I., Peiró, J. \& Ferreira, L. (2006). El estado del contrato psicológico y su relación con la salud psicológica de los empleados. Psicothema, 2(18), 256-262.

Hernández, R., Fernández, C. \& Baptista, P. (2010). Metodología de la investigación. McGraw Hill.

Heuvel, S. \& Schalk, R. (2009). The relationship between fulfilment of the psychological contract and resistance to change during organizational transformations. Journal Social Science Information, 48(2), 283-313. doi: 10.1177/0539018409102415

Huerta, P., Pedraja, L., Contreras, S. \& Almodóvar, P. (2011). Calidad de vida laboral y su influencia sobre los resultados empresariales. Revista de Ciencias Sociales, 17(4), 658-676.

Jacobs, G., Witteloostuijn, A. \& Christe-Zeyse, J. (2013). A theoretical framework of organizational change. Journal of Organizational Change Management, 26(5), 772-792. doi 10.1108/JOCM-09-2012-0137

Janssens, M., Sels, L. \& Van den Brande, I. (2003). Multiple types of psychological contracts: A six-cluster solution. Human Relations, 56(11), 1349-1378.

Lines, R. (2005). The structure and function of attitudes toward organizational change. $\mathrm{Hu}$ man Resource Development Review, 4(1), 8-32. doi: 10.1177/1534484304273818 
MacNeil, I. (1985). Relational contract. What we do not know. Wisconsin Law Review, 3, 483525.

Martínez, G., De Cuyper, N \& De Witte, H. (2010). Revisión de la literatura sobre inseguridad en el trabajo: el caso de Latinoamérica. Avances en Psicología Latinoamericana, 28(2), 194-204.

Mejbel, A., Khalid, M., Siron, A \& Alnaser, A. (2013). The drivers of quality of working life (QWL): A critical review. Australian Journal of Basic and Applied Sciences, 7(10), 398405.

Oktug, Z. (2013). The moderating effects of age and tenure on the relationship between organizational identification and job satisfaction. Management, 3(4), 218-222. doi: 10.5923/j. mm.20130304.04

Oreg, S. (2006). Personality, context and resistance to organizational change. European journal of work and organizational psychology, 15(1), 73-101. doi: 10.1080/13594320500451247

Patrick, H. (2008). Psychological contract and employment relationship. Journal of Organizational Behavior, 7(4), 7-24.

Quijada, F. (2009). Cultura de calidad del servicio y contrato psicológico en empleados del IAIM. (Tesis de maestría). Universidad Católica Andrés Bello. http://biblioteca2.ucab.edu.ve/ anexos/biblioteca/marc/texto/AAR7468.pdf

Rafferty, A. \& Restubog, S. (2010). The impact of change process and context on change reactions and turnover during a merger. Journal of Management, 36(5), 1309-1338. doi: $10.1177 / 0149206309341480$

Robinson, S. (1996). Trust and breach of the psychological contract. Administrative Science Quarterly, 41, 574-599. doi: 10.2307/2393868

Rousseau, D. (1989). Psychological and implied contracts in organizations. Employee Responsibilities and Rights Journal, 2(2), 121-139.

Rousseau, D. (2000). Psychologycal contracts inventory. Technical report (version 2) UUSS.

Segurado, A. \& Agulló, E. (2002). Calidad de vida laboral: hacia un enfoque integrador desde la psicología social. Psicothema, 14(4), 828-836.

Sousa, C. (2006). Estudio comparativo del contrato psicológico en empleados temporales y permanentes. Universidad Católica Andrés Bello.

Toro, F. (1991). Desempeño y productividad. Contribuciones de la psicología organizacional. Medellín: Cincel.

Zimmermann A. (2000). Gestión del cambio organizacional. Caminos y herramientas. Abya-Yala. 



\section{6 \\ APROXIMACIÓN A LA DINÁMICA \\ DEL CONTENIDO DEL CONTRATO \\ PSICOLÓGICO EN MÉXICO: \\ ESTUDIO COMPARATIVO \\ ENTRE TRABAJADORES DE \\ ORGANZACIONES DE LA INCIATIVA \\ PRIVADA E INSTITUCIONES \\ DE GOBIERNO}

Emmanuel Martínez-Mejía*

Universidad Nacional Autónoma de México

Erika Mariana Ascencio Cabrera**

Investigación en Psicología Organizacional S.C.

Carlos-María Alcover***

Universidad Rey Juan Carlos

\section{Introducción}

El contrato psicológico (CP) es un constructo que, basado fundamentalmente en la teoría del intercambio social (Homans, 1974; Blau, 1964) y en la norma de reciprocidad (Gouldner, 1960), proporciona un marco explicativo desde la psicología organizacional para entender la relación empleador-empleado (Coyle-Shapiro, Costa, Doden \& Chang, 2019). El intercambio social aplicado a las relaciones laborales se refiere a la evaluación de los empleados sobre las interacciones e intercambios sociales como indicador de futuros comportamientos de reciprocidad por su inversión de esfuerzo y lealtad a cambio de la provisión material y de beneficios socioemocionales por parte de la organización (Coyle-Shapiro \& Conway, 2005; Eisenberger et ál., 1986; Gould, 1979; Rousseau, 1995; Aseagle y Eisenberger, 2003). En este marco de referencia teórico, la importancia y consolidación del CP como constructo explicativo

\footnotetext{
* https://orcid.org/0000-0002-4095-359X

** https://orcid.org/0000-0002-9830-9035

*** https://orcid.org/0000-0001-9632-9107
} 
en las organizaciones se ha puesto en evidencia desde su primera mención como contrato de trabajo psicológico por Agyris (1960); con una aproximación más fundamentada, se definió como "las creencias del individuo acerca de los términos y condiciones de un acuerdo de intercambio recíproco" (Rousseau, 1989, p. 123); hasta hacer particular énfasis en que estas "creencias de los empleados acerca de las obligaciones recíprocas existentes entre ellos y su organización constituyen el fundamento de las relaciones laborales" (Morrison \& Robinson, 1997, p. 226). De esta forma, los empleados construyen el CP a través de interacciones con los diversos agentes organizacionales (Alcover, Rico, Turnley \& Bolino, 2017a), no con la "organización” como un todo. Esta aproximación de múltiples focos del CP considera cómo los empleados establecen diversos vínculos simultáneamente y a lo largo del tiempo con los agentes organizacionales, vínculos que les permiten mantener el empleo y progresar en su carrera profesional (Alcover et ál., 2017a; Baruch y Rousseau, 2018).

El enfoque teórico que guiará nuestra investigación es el propuesto por Rousseau (1995), quien señala que las organizaciones deben tomar en cuenta dos aspectos fundamentales en los términos del CP: el marco temporal y los requerimientos de rendimiento. El marco temporal se puede definir a corto o largo plazo, mientras que los requerimientos de rendimiento pueden estar bien especificados o débilmente especificados. La combinación de estas dos características da lugar a un modelo que identifica cuatro tipos de contratos psicológicos (Rousseau, 1995; Rousseau, 2000; Alcover, 2002; Rousseau, 2004):

1. Transaccionales. Duración limitada y términos bien especificados del rendimiento y las recompensas materiales que se obtendrán a cambio.

2. Relacionales. Abiertos, con garantías de continuidad a largo plazo y contenido de naturaleza socioemocional.

3. Balanceados. Abiertos, orientados a la continuidad, con requisitos de rendimiento bien especificados, aunque sujetos a cambios a lo largo del tiempo.

4. Transicionales. Ausencia de compromisos futuros, pocas y ambiguas demandas de rendimiento e incentivos contingentes; aunque no se ha considerado estrictamente un tipo de CP, refleja un estado psicológico sobre las consecuencias de los cambios organizacionales y laborales.

En cuanto a su relevancia y actualidad como variable de estudio, al hacer una revisión hasta el 14 de diciembre de 2018 sobre el estatus de la investigación sobre el CP en el buscador académico Discovery Service para la Universidad Nacional Autónoma de México (UNAM), que administra EBSCOhost con diferentes proveedores de bases de datos, con las palabras clave en inglés "psychological contract", tomando como indicador las publicaciones arbitradas, se identificaron 3778 publicaciones académicas 
arbitradas solamente en las que el contrato psicológico es la variable central (acotándola al título del artículo), mientras que con las palabras clave en español "contrato psicológico" se identificaron solamente 99. En México la investigación es incipiente, y los pocos estudios que se pueden encontrar muestran un gran interés por su utilidad para explicar algunos fenómenos laborales desde la psicología organizacional (DíazSáenz \& Witherspoon, 2000; Martínez-Mejía, 2016; Martínez-Mejía, 2018; Máynez, Cavazos \& Reyes, 2017).

En particular, como señalan Gracia, Peiró y Mañas (2007), el estudio del CP se ha centrado principalmente en la iniciativa privada (en adelante IP) como contexto organizacional y requiere considerarse también el sector público, ya que existen diferencias estructurales organizacionales que tienen un impacto significativo en las características de las relaciones laborales y las prácticas de dirección. En la presente investigación consideramos importante no solo analizar el CP en uno o en otro contexto organizacional, sino evaluar si existen diferencias en su contenido. Por tanto, el objetivo general de esta investigación es identificar las características del contenido del contrato psicológico y la comparación de su configuración en empleados mexicanos de organizaciones tanto de la IP como del gobierno; los objetivos específicos, por su parte, son: 1) aportar evidencia a la validez y confiabilidad del inventario de contrato psicológico en población mexicana; 2) conocer las características del contenido del CP en México; y 3) poner a prueba modelos de interdependencia entre los elementos del contenido del contrato psicológico en México.

\section{Método}

Se realizó un estudio descriptivo y correlacional para identificar las características del contenido del CP, así como para evaluar la dirección y fuerza de la relación entre sus elementos en trabajadores mexicanos tanto de organizaciones de la IP como del gobierno.

\section{Hipótesis}

H1: El inventario de contrato psicológico mostrará validez de constructo y confiabilidad en la población mexicana.

H2: Habrá características diferenciadas entre los elementos del contenido del contrato psicológico de los empleados de la iniciativa privada y el gobierno.

H3: Habrá diferencias entre las configuraciones de los modelos correlacionales de los elementos del contenido del contrato psicológico de la iniciativa privada y el gobierno. 


\section{Participantes}

Participaron 493 empleados de diferentes organizaciones; 290 fueron de la IP y 203 del gobierno, tanto hombres (60\%) como mujeres ( $40 \%$ ), de puestos de niveles operativos $(51,5 \%)$, mandos medios (29\%) y directivo-gerenciales $(19,3 \%)$, con un muestreo intencional no probabilístico.

\section{Instrumentos}

Se utilizó la adaptación al español del inventario de contrato psicológico (ICP), midiendo las escalas y subescalas de los tipos relacional, transaccional, balanceado y transicional, tanto para las obligaciones del empleador como para las obligaciones del empleado en todos los factores; cada subescala está integrada por cuatro ítems, excepto la subescala de empleabilidad del empleado, con tres ítems (Alcover \& Martínez-Î́nigo, 2005; Rousseau, 2000), con una escala de respuesta tipo Likert de cinco (5) puntos desde totalmente en desacuerdo hasta totalmente de acuerdo. Los tipos, escalas y subescalas son las siguientes:

CP transaccional:

- Corto plazo. Empleador. Ej. El trabajo durará mientras mi empleador me necesite. Empleado. Ej. Puedo marcharme a la menor oportunidad.

- Limitado. Empleador. Ej. Me exigen el desempeño de un conjunto de actividades limitada. Empleado. Ej. Hacer solo las actividades por las que me pagan.

CP relacional

- Lealtad. Empleador. Ej. Muestran interés por mi bienestar a largo plazo. Empleado. Ej. Proteger la imagen de esta organización.

- Seguridad. Empleador. Ej. Me ofrecen un empleo seguro. Empleado. Ej. Permanecer en esta organización indefinidamente.

CP balanceado

- Rendimiento. Empleador. Ej. Me ofrecen las condiciones necesarias para ajustarme a demandas de rendimiento nuevas y desafiantes. Empleado. Ej. Aceptar nuevas $y$ diferentes exigencias de rendimiento.

- Desarrollo Interno. Empleador. Ej. Me ofrecen oportunidades de ascenso. Empleado. Ej. Desarrollar habilidades para incrementar mi valor para esta organización. 
Empleabilidad. Empleador. Ej. Me ayuda a desarrollar habilidades que son apreciadas en el mercado laboral externo. Empleado. Ej. Desarrollar habilidades para incrementar mis oportunidades futuras de empleo en otra parte.

$\mathrm{CP}$ transicional.

- Desconfianza. Empleador. Ej. Actúa como si no confiara en sus empleados. Empleado. Ej. No creo lo que mi empleador me dice.

- Incertidumbre. Empleador. Ej. Es difícil predecir la dirección futura de sus relaciones conmigo. Empleado. Ej. Mi compromiso hacia mi empleador es incierto.

Erosión. Empleador. Ej. Más y más trabajo por menos sueldo. Empleado. Ej. Estoy haciendo más de lo que me pagan por hacer.

\section{Procedimiento}

Se aplicó el ICP en un cuestionario de autoinforme a trabajadores de organizaciones de la IP y del gobierno. Se realizó un muestreo no probabilístico, por oportunidad y bola de nieve (Hudelson, 1994; Hernández, Fernández \& Baptista, 2014), con el criterio de inclusión de reportar tener un contrato formal de trabajo.

Una vez que se recolectaron los cuestionarios, se realizaron diversos análisis estadísticos con el programa SPSS25 y AMOS18. Se realizaron análisis descriptivos para conocer las características de la muestra. Respecto a la validez de constructo y fiabilidad del ICP, se aplicó el análisis factorial confirmatorio (AFC) para cada subescala y análisis de consistencia interna, utilizando la muestra total (Pérez-Gil, 2000; Rial et ál., 2006). En este sentido, los modelos de medida se establecieron con base en dos criterios: a) la estructura teórica (Rousseau, 1995) y b) estudios exploratorios previos (Rousseau, 2000).

En el análisis para la comparación de grupos, se realizaron análisis $t$ de Student para comparar las subescalas del ICP entre la iniciativa privada y el gobierno, así como análisis descriptivo para las características del contenido del CP. Para los análisis correlacionales, se realizaron análisis de regresión lineal múltiple y especificación de modelos PATH tanto para la muestra de trabajadores de la IP como para la muestra de gobierno.

\section{Resultados}

En primer lugar, alcanzar el objetivo de este estudio implica mostrar evidencia sobre el modelo de medida y consistencia interna (Muñiz, 1998; Muñiz, Elosua \& 
Hambleton, 2013), en la población mexicana, del ICP (Rousseau, 2000), que es una medida orientada al contenido desde la perspectiva del empleado. Las medidas del contenido de los contratos psicológicos están dirigidas hacia los términos y obligaciones recíprocas, y se puede obtener a partir de la perspectiva del empleado, de la perspectiva del empleador o de ambas (Rousseau \& Tijoriwala, 1998; Freese \& Schalk, 2016).

En nuestros resultados del AFC, en general, los indicadores muestran un ajuste moderado, susceptible de ser mejorado (tabla 1). La subescala de las creencias del empleado que mostró el mejor ajuste fue la transaccional; mientras que la mejor subescala de las creencias sobre el empleador fue la transicional. En cuanto al índice de consistencia interna alfa de Cronbach, las subescalas obtuvieron índices aceptables (Lévy-Mangin \& Varela, 2006) excepto la transaccional empleador (tabla 1), con lo que podemos señalar que se cumple de manera parcial nuestra $\mathrm{H} 1$.

Tabla 1. Índices de bondad de ajuste del AFC de las subescalas del ICP en la muestra total de trabajadores mexicanos

\begin{tabular}{|c|c|c|c|c|c|c|c|c|c|c|c|c|}
\hline & Alpha & ji2 & g.l. & $P$ & ji2/g.l. & GFI & RMSA & AGFI & CFI & $\mathrm{NFI}$ & RMR & TLI \\
\hline \multicolumn{13}{|l|}{ Empleador } \\
\hline Transicional & .914 & 243.691 & 51 & .000 & 4.778 & .926 & .088 & .886 & .933 & .917 & .069 & .914 \\
\hline Relacional & .873 & 95.519 & 19 & .000 & 5.027 & .953 & .090 & .910 & .956 & .946 & .076 & .935 \\
\hline Transaccional & .589 & 106.411 & 19 & .000 & 5.601 & .943 & .097 & .893 & .780 & .750 & .119 & .676 \\
\hline Balanceado & .914 & 327.611 & 51 & .000 & 6.424 & .897 & .105 & .842 & .914 & .901 & .086 & .889 \\
\hline \multicolumn{13}{|l|}{ Empleado } \\
\hline Transaccional & .660 & 43.387 & 19 & .001 & 2.284 & .979 & .051 & .960 & .958 & .928 & .069 & .938 \\
\hline Relacional & .785 & 78.741 & 19 & .000 & 4.144 & .958 & .080 & .920 & .949 & .935 & .058 & .925 \\
\hline Transicional & .907 & 199.641 & 41 & .000 & 4.869 & .931 & .089 & .890 & .938 & .923 & .061 & .916 \\
\hline Balanceado & .763 & 269.028 & 51 & .000 & 5.275 & .922 & .093 & .881 & .847 & .819 & .122 & .802 \\
\hline
\end{tabular}

Notas: Alpha = Alpha de Cronbach; ji ${ }^{2}=$ Chi cuadrada; g. I. = grados de libertad; $p=$ probabilidad; ji2/g.l. =; GFI = Godness of Fit Index; RMSA = Root Mean Squared Error Aproximation; AGFI = Adjusted Goodness of Fit Index; CFI = Comparative Fit Index; NFI = Normed Fit Index; RMR = Root Mean Square Residual; TLI = TuckerLewis Index. El orden de los modelos se muestra por su ajuste en el bloque Empleador y Empleado. Fuente: Elaboración propia. 
En segundo lugar, mostraremos las características descriptivas y las diferencias en el contenido del CP en la IP y el gobierno en una muestra de trabajadores mexicanos; para esto, se realizaron análisis descriptivos y con la prueba $t$ de Student, para comparar los elementos del CP entre los trabajadores de la IP y los del gobierno. Con base en nuestros resultados, podemos señalar que en algunas de las subescalas se cumple nuestra $\mathrm{H} 2$; a continuación mostramos esos resultados.

Al comparar las creencias sobre las obligaciones del empleador, se encontraron diferencias estadísticamente significativas en la creencia de que el empleador ofrece seguridad, en donde los trabajadores del gobierno mostraron el puntaje promedio más alto (tabla 2). Ahora bien, en el reporte técnico del psychological contract inventory (Rousseau, 2000), se indican datos descriptivos de los puntajes obtenidos en las subescalas en una muestra de Estados Unidos y en otra de Singapur; al tomar esos resultados en cuenta, en la figura 1 se muestra, de manera descriptiva, la comparación entre la muestra del presente estudio y los reportados por Rousseau (2000), sobre la creencia de seguridad del empleador.

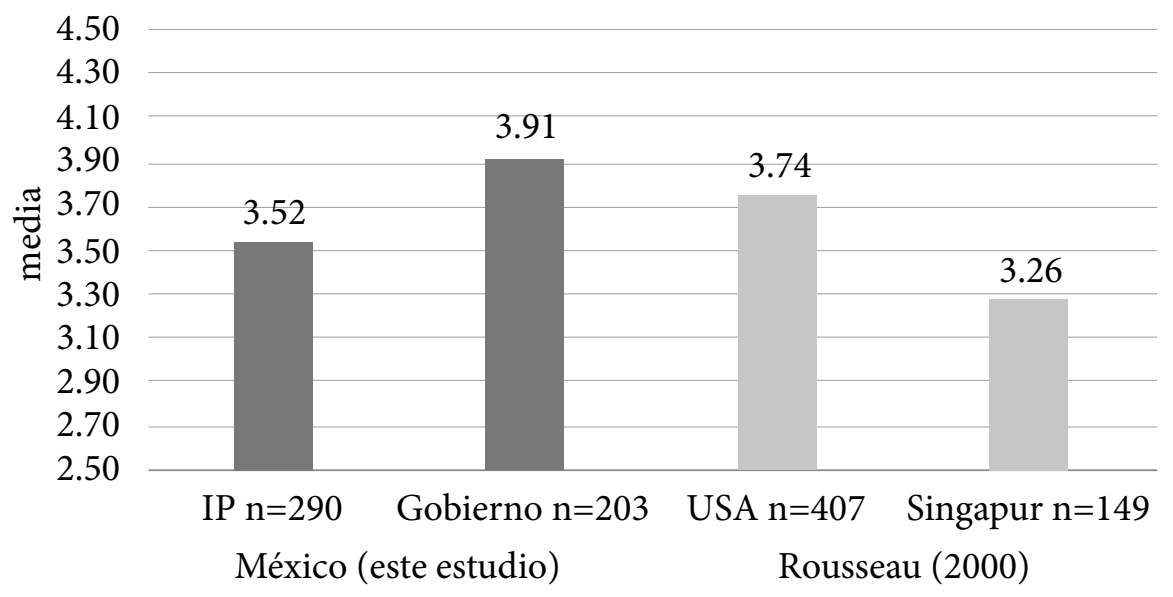

Figura 1. Puntaje medio de la creencia de seguridad del empleador en las muestras de la Iniciativa Privada (IP) y gobierno de este estudio, y muestras de USA y Singapur. Fuente: Rousseau (2000).

Respecto a las obligaciones del empleado, se encontraron diferencias estadísticamente significativas en las obligaciones de lealtad y seguridad del empleado; en ambos aspectos los empleados del gobierno mostraron los puntajes promedio más altos. En la figura 2 se muestra, de manera descriptiva, la comparación entre la muestra de nuestro estudio y los reportados por Rousseau (2000), sobre la lealtad del empleador. 
Tabla 2. Análisis de comparación con la prueba t de Student entre la IP y el gobierno sobre las obligaciones empleador en los tipos de contrato

\begin{tabular}{|c|c|c|c|c|c|c|}
\hline Tipo & & $\mathrm{N}$ & Media & DT & $t$ & Sig. \\
\hline \multirow{6}{*}{ Relacional } & Lealtad & 493 & 3.3217 & 1.03444 & & \\
\hline & IP & 290 & 3.3149 & 1.02188 & & \\
\hline & Gobierno & 203 & 3.3313 & 1.0546 & -0.173 & 0.863 \\
\hline & Seguridad & 493 & 3.6802 & 1.03524 & & \\
\hline & IP & 290 & 3.5219 & 1.05335 & & \\
\hline & Gobierno & 203 & 3.9064 & 0.96721 & -4.124 & 0.000 \\
\hline \multirow{6}{*}{ Transaccional } & Corto plazo & 493 & 2.6362 & .89476 & & \\
\hline & IP & 290 & 2.6356 & 0.88532 & & \\
\hline & Gobierno & 203 & 2.6371 & 0.91028 & -0.019 & 0.985 \\
\hline & Limitado & 493 & 3.3217 & 1.03444 & & \\
\hline & IP & 290 & 3.3149 & 1.02188 & & \\
\hline & Gobierno & 203 & 3.3313 & 1.0546 & -0.173 & 0.863 \\
\hline \multirow{9}{*}{ Balanceado } & Rendimiento & 493 & 3.5723 & .96217 & & \\
\hline & IP & 290 & 3.5778 & 0.97421 & & \\
\hline & Gobierno & 203 & 3.5644 & 0.94704 & 0.151 & 0.88 \\
\hline & Desarrollo interno & 493 & 3.5822 & 1.05641 & & \\
\hline & IP & 290 & 3.5898 & 1.07153 & & \\
\hline & Gobierno & 203 & 3.5714 & 1.03698 & 0.189 & 0.85 \\
\hline & Empleabilidad & 493 & 3.1513 & .95573 & & \\
\hline & IP & 290 & 3.2092 & 0.93994 & & \\
\hline & Gobierno & 203 & 3.0686 & 0.9742 & 1.61 & 0.108 \\
\hline \multirow{9}{*}{ Transicional } & Desconfianza & 493 & 2.3405 & 1.02079 & & \\
\hline & IP & 290 & 2.3262 & 0.99353 & & \\
\hline & Gobierno & 203 & 2.3608 & 1.06067 & -0.37 & 0.712 \\
\hline & Incertidumbre & 493 & 2.4390 & 1.04733 & & \\
\hline & IP & 290 & 2.4259 & 1.0032 & & \\
\hline & Gobierno & 203 & 2.4577 & 1.10958 & -0.331 & 0.741 \\
\hline & Erosión & 493 & 2.4468 & 1.05079 & & \\
\hline & IP & 290 & 2.4529 & 1.02943 & & \\
\hline & Gobierno & 203 & 2.4382 & 1.08307 & 0.153 & 0.878 \\
\hline
\end{tabular}

Notas: IP = Iniciativa privada. En negrillas se enfatiza el puntaje medio más alto, el estadístico $t$ y su nivel de significancia, en aquellas comparaciones que resultaron con diferencias significativas. Fuente: Elaboración propia. 


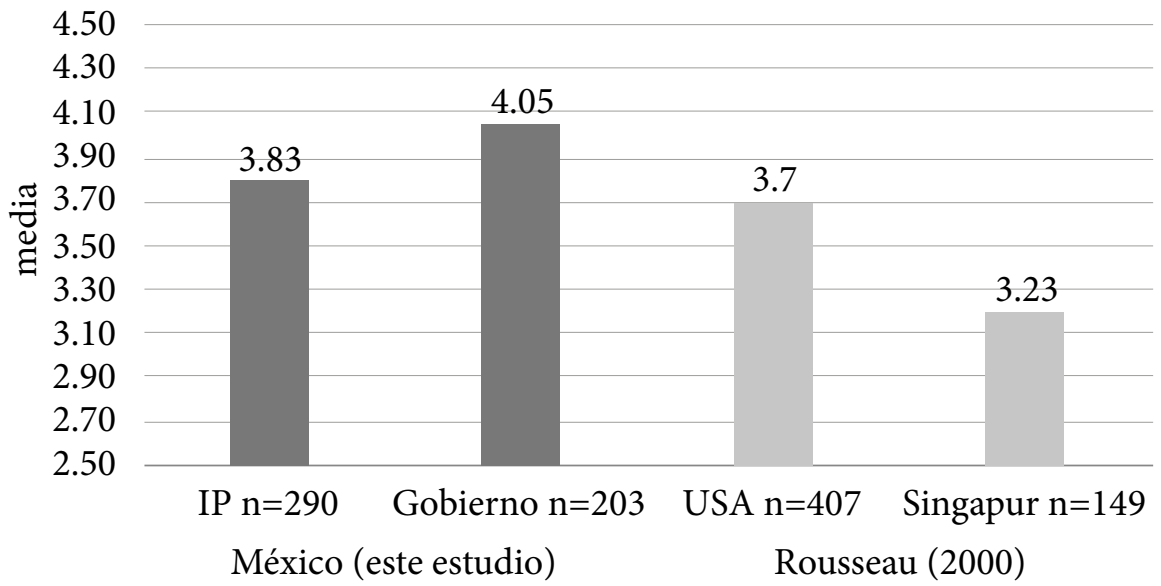

Figura 2. Puntaje medio de la creencia de lealtad del empleado en las muestras de la Iniciativa Privada y gobierno de este estudio, y muestras de USA y Singapur. Fuente: Rousseau (2000).

Por otro lado, se encontraron diferencias estadísticamente significativas en las obligaciones del empleado de desarrollar habilidades que se valoran en el mercado de trabajo, en donde los empleados de la IP mostraron los puntajes promedio más altos. También se encontraron diferencias en la incertidumbre que muestran los empleados de la IP sobre su compromiso y obligaciones hacia su organización (tabla 3).

Finalmente, para alcanzar el objetivo de esta investigación se realizaron análisis correlacionales que sustentaran la especificación de modelos de regresión lineal múltiple y modelos PATH para aportar evidencia sobre la H3 de una configuración diferenciada entre el CP de trabajadores de la IP y el de instituciones de gobierno en México.

Respecto a la dinámica del CP en la IP, se encontraron correlaciones estadísticamente significativas entre las obligaciones del empleador y las del empleado (tablas 4-7). A partir de estas correlaciones, se realizaron modelos de regresión lineal múltiple tomando como variable dependiente las obligaciones del empleado para identificar las obligaciones del empleador relacionadas como antecedentes (independientes).

En el CP transaccional, la creencia de que el empleador ofrece una relación a corto plazo es la principal variable que predice tanto el compromiso a corto plazo como el establecimiento de obligaciones y trabajo limitado del empleado (tabla 8). En el CP relacional, la creencia de que el empleador ofrece seguridad y estabilidad de la relación laboral es la principal variable que predice tanto la lealtad como la seguridad de permanencia del empleado (tabla 9). 
Tabla 3. Análisis de comparación con la prueba t de Student entre la IP y el gobierno sobre las obligaciones empleado en los tipos de contrato

\begin{tabular}{|c|c|c|c|c|c|c|}
\hline Tipo & & $\mathrm{N}$ & Media & DT & $t$ & Sig. \\
\hline \multirow{6}{*}{ Relacional } & Lealtad & 493 & 3.9205 & .80744 & & \\
\hline & IP & 290 & 3.832 & 0.83981 & & \\
\hline & Gobierno & 203 & 4.0468 & 0.74272 & -2.929 & 0.004 \\
\hline & Seguridad & 493 & 3.5196 & .90344 & & \\
\hline & IP & 290 & 3.4212 & 0.92861 & & \\
\hline & Gobierno & 203 & 3.6601 & 0.84884 & -2.911 & 0.004 \\
\hline \multirow{6}{*}{ Transaccional } & Corto Plazo & 493 & 2.6072 & .77451 & & \\
\hline & IP & 290 & 2.5676 & 0.70964 & & \\
\hline & Gobierno & 203 & 2.6638 & 0.85738 & -1.359 & 0.175 \\
\hline & Limitado & 493 & 2.4686 & 1.03969 & & \\
\hline & IP & 290 & 2.5146 & 1.04472 & & \\
\hline & Gobierno & 203 & 2.4029 & 1.03146 & 1.175 & 0.241 \\
\hline \multirow{9}{*}{ Balanceado } & Rendimiento & 493 & 4.0397 & .74941 & & \\
\hline & IP & 290 & 4.0459 & 0.79042 & & \\
\hline & Gobierno & 203 & 4.0309 & 0.68841 & 0.217 & 0.828 \\
\hline & Desarrollo Interno & 493 & 3.7186 & .70507 & & \\
\hline & IP & 290 & 3.6989 & 0.73945 & & \\
\hline & Gobierno & 203 & 3.7467 & 0.6536 & -0.74 & 0.46 \\
\hline & Empleabilidad & 493 & 3.3642 & .93392 & & \\
\hline & IP & 290 & 3.5449 & 0.87614 & & \\
\hline & Gobierno & 203 & 3.1061 & 0.95517 & 5.272 & 0.000 \\
\hline \multirow{9}{*}{ Transicional } & Desconfianza & 493 & 2.2859 & .95488 & & \\
\hline & IP & 290 & 2.3244 & 0.93781 & & \\
\hline & Gobierno & 203 & 2.2307 & 0.97844 & 1.073 & 0.284 \\
\hline & Incertidumbre & 493 & 2.4455 & .98358 & & \\
\hline & IP & 290 & 2.5334 & 0.94187 & & \\
\hline & Gobierno & 203 & 2.3198 & 1.02963 & 2.384 & 0.018 \\
\hline & Erosión & 493 & 2.4638 & 1.04264 & & \\
\hline & IP & 290 & 2.4619 & 0.98236 & & \\
\hline & Gobierno & 203 & 2.4665 & 1.12566 & -0.048 & 0.961 \\
\hline
\end{tabular}

Nota: En negrillas se enfatiza el puntaje medio más alto, el estadístico $t$ y su nivel de significancia, en aquellas comparaciones que resultaron con diferencias significativas. Fuente: Elaboración propia. 
Tabla 4. Correlaciones entre las creencias de obligaciones del empleador en la IP

\begin{tabular}{|c|c|c|c|c|c|c|c|c|c|c|}
\hline & L_Er & S_Er & CP_Er & Lim_Er & R_Er & DI_Er & Em_Er & D_Er & I_Er & Er_Er \\
\hline L_Er & 1 & & & & & & & & & \\
\hline S_Er & $.713^{\star *}$ & 1 & & & & & & & & \\
\hline CP_Er & $-.278^{* *}$ & $-.367^{\star *}$ & 1 & & & & & & & \\
\hline Lim_Er & $.427^{\star *}$ & $.298^{\star *}$ & $.218^{\star \star}$ & 1 & & & & & & \\
\hline R_Er & $.778^{\star \star}$ & $.702^{\star *}$ & $-.248^{\star *}$ & $.385^{\star *}$ & 1 & & & & & \\
\hline DI_Er & $.710^{\star *}$ & $.666^{* *}$ & $-.197^{\star *}$ & $.346^{\star *}$ & $.797^{\star *}$ & 1 & & & & \\
\hline Em_Er & $.648^{\star *}$ & $.648^{* *}$ & $-.131^{*}$ & $.296^{* *}$ & $.698^{* *}$ & $.718^{\star *}$ & 1 & & & \\
\hline D_Er & $-.527^{\star \star}$ & $-.446^{\star *}$ & $.225^{\star \star}$ & $-.144^{\star}$ & $-.472^{\star *}$ & $-.513^{\star \star}$ & $-.396^{\star \star}$ & 1 & & \\
\hline I_Er & $-.536^{\star *}$ & $-.510^{\star *}$ & $.354^{* *}$ & -0.085 & $-.509^{\star *}$ & $-.536^{\star *}$ & $-.387^{\star *}$ & $.723^{* *}$ & 1 & \\
\hline E_Er & $-.594^{\star *}$ & $-.588^{\star *}$ & $.290^{\star *}$ & $-.176^{\star *}$ & $-.537^{\star *}$ & $-.527^{\star \star}$ & $-.412^{* *}$ & $.698^{* *}$ & $.730^{* *}$ & 1 \\
\hline
\end{tabular}

Notas: L_Er = Lealtad del empleador; S_Er = Seguridad del empleador; $\mathrm{CP} E \mathrm{Er}=$ Corto plazo del empleador; Lim_Er = Limitado del empleador; R_Er = Rendimiento del empleador; DI_Er = Desarrollo interno del empleador; Em_Er = Empleabilidad del empleador; D_Er = Desconfianza hacia el empleador; I_Er = Incertidumbre sobre el empleador; Er_Er = Erosión del empleador. ${ }^{\star} p<.05,{ }^{\star \star} p<.01,{ }^{\star \star *} p<.001$. Fuente: Elaboración propia.

Tabla 5. Correlaciones de las creencias de obligaciones del empleador y las obligaciones del empleado en la IP

\begin{tabular}{|c|c|c|c|c|c|c|c|c|c|c|}
\hline & L_Er & S_Er & CP_Er & Lim_Er & R_Er & DI_Er & Em_Er & D_Er & I_Er & Er_Er \\
\hline L_Edo & $.499^{* *}$ & $.528^{* *}$ & $-.311^{* *}$ & $.198^{\star *}$ & $.479^{* *}$ & $.431^{* *}$ & $91^{* *}$ & $284^{* *}$ & $-.326^{* *}$ & $367^{* *}$ \\
\hline S_Edo & $.455^{\star \star}$ & $.533^{\star \star}$ & $-.244^{* *}$ & $.242^{\star \star}$ & $.483^{\star *}$ & $.473^{* *}$ & $.437^{\star *}$ & $-.357^{\star *}$ & $-.354^{\star *}$ & $-.410^{\star *}$ \\
\hline CP_Edo & $-.119^{*}$ & -0.089 & $.292^{* *}$ & 0.047 & $-.147^{\star}$ & $-.124^{\star}$ & -0.042 & $.182^{* *}$ & $.193^{* *}$ & $.143^{*}$ \\
\hline L_Edo & $-.275^{\star \star}$ & $-.337^{\star *}$ & $.386^{* *}$ & 0.089 & $-.225^{* *}$ & $-.271^{* *}$ & $-.227^{\star *}$ & $.209^{* *}$ & $.317^{* *}$ & $.232^{\star *}$ \\
\hline R_Edo & $.426^{* *}$ & $.480^{* *}$ & $-.209^{* *}$ & $.315^{\star *}$ & $.516^{\star *}$ & $.478^{* *}$ & $.353^{\star *}$ & $-.303^{* *}$ & $-.306^{* *}$ & $-.288^{\star *}$ \\
\hline DI_Edo & $.323^{\star *}$ & $.277^{\star *}$ & -0.001 & $.269^{* *}$ & $.378^{\star *}$ & $.389^{* *}$ & $.316^{\star *}$ & $-.172^{\star *}$ & $-.177^{\star *}$ & $-.139^{*}$ \\
\hline Em_Edo & 0.021 & -0.056 & $.284^{\star *}$ & $.187^{\star *}$ & 0.069 & 0.076 & $.139^{\star}$ & 0.103 & $.127^{\star}$ & $.155^{\star *}$ \\
\hline D_Edo & $-.485^{\star *}$ & $-.457^{\star *}$ & $.296^{\star *}$ & $-.121^{*}$ & $-.465^{\star *}$ & $-.457^{\star *}$ & $-.391^{\star *}$ & $.503^{\star *}$ & $.543^{\star *}$ & $.545^{\star *}$ \\
\hline I_Edo & $-.440^{\star *}$ & $-.414^{* *}$ & $.326^{* *}$ & -0.094 & $-.403^{\star *}$ & $-.413^{* *}$ & $-.317^{\star *}$ & $.524^{\star *}$ & $.646^{* *}$ & $.590^{* *}$ \\
\hline Er_Edo & $-.411^{\star *}$ & $-.501^{\star *}$ & $.250^{\star *}$ & $-.115^{*}$ & $-.428^{* *}$ & $-.411^{* *}$ & $-.320^{* *}$ & $.509^{\star *}$ & $.575^{\star *}$ & $.674^{* *}$ \\
\hline
\end{tabular}

Notas: L_Er = Lealtad del empleador; S_Er = Seguridad del empleador; $\mathrm{CP} E \mathrm{Er}=$ Corto plazo del empleador; Lim_Er = Limitado del empleador; R_Er = Rendimiento del empleador; DI_Er = Desarrollo interno del empleador; Em_Er = Empleabilidad del empleador; D_Er = Desconfianza hacia el empleador; I_Er = Incertidumbre sobre el empleador; Er_Er = Erosión del empleador. L_Edo = Lealtad del empleado; S_Edo = Seguridad del empleado; $\mathrm{CP}_{-} E d o=$ Corto plazo del empleado; Lim_Edo = Limitado del empleado; R_Edo = Rendimiento del empleado; DI_Edo = Desarrollo interno del empleado; Em_Edo = Empleabilidad del empleado; $D \_E d o=$ Desconfianza del empleado; I_Edo = Incertidumbre del empleado; Er_Edo = Erosión del empleado. ${ }^{*} p<.05$, ${ }^{\star \star} p<.01,{ }^{\star \star *} p<.001$. Fuente: Elaboración propia. 
Aproximación a la dinámica del contenido del contrato psicológico en México

Tabla 6. Correlaciones de las creencias de obligaciones del empleado y las obligaciones del empleador en la IP

\begin{tabular}{ccccccccccc}
\hline & L_Edo & S_Edo & CP_Edo & Lim_Edo & R_Edo & DI_Edo & Em_Edo & D_Edo & I_Edo & Er_Edo \\
\hline L_Er & $.499^{* *}$ & $.455^{* *}$ & $-.119^{*}$ & $-.275^{* *}$ & $.426^{* *}$ & $.323^{* *}$ & 0.021 & $-.485^{* *}$ & $-.440^{* *}$ & $-.411^{* *}$ \\
S_Er & $.528^{* *}$ & $.533^{* *}$ & -0.089 & $-.337^{* *}$ & $.480^{* *}$ & $.277^{* *}$ & -0.056 & $-.457^{* *}$ & $-.414^{* *}$ & $-.501^{* *}$ \\
CP_Er & $-.311^{* *}$ & $-.244^{* *}$ & $.292^{* *}$ & $.386^{* *}$ & $-.209^{* *}$ & -0.001 & $.284^{* *}$ & $.296^{* *}$ & $.326^{* *}$ & $.250^{* *}$ \\
Lim_Er & $.198^{* *}$ & $.242^{* *}$ & 0.047 & 0.089 & $.315^{* *}$ & $.269^{* *}$ & $.187^{* *}$ & $-.121^{*}$ & -0.094 & $-.115^{*}$ \\
R_Er & $.479^{* *}$ & $.483^{* *}$ & $-.147^{*}$ & $-.225^{* *}$ & $.516^{* *}$ & $.378^{* *}$ & 0.069 & $-.465^{* *}$ & $-.403^{* *}$ & $-.428^{* *}$ \\
DI_Er & $.431^{* *}$ & $.473^{* *}$ & $-.124^{*}$ & $-.271^{* *}$ & $.478^{* *}$ & $.389^{* *}$ & 0.076 & $-.457^{* *}$ & $-.413^{* *}$ & $-.411^{* *}$ \\
Em_Er & $.391^{* *}$ & $.437^{* *}$ & -0.042 & $-.227^{* *}$ & $.353^{* *}$ & $.316^{* *}$ & $.139^{*}$ & $-.391^{* *}$ & $-.317^{* *}$ & $-.320^{* *}$ \\
D_Er & $-.284^{* *}$ & $-.357^{* *}$ & $.182^{* *}$ & $.209^{* *}$ & $-.303^{* *}$ & $-.172^{* *}$ & 0.103 & $.503^{* *}$ & $.524^{* *}$ & $.509^{* *}$ \\
I_Er & $-.326^{* *}$ & $-.354^{* *}$ & $.193^{* *}$ & $.317^{* *}$ & $-.306^{* *}$ & $-.177^{* *}$ & $.127^{*}$ & $.543^{* *}$ & $.646^{* *}$ & $.575^{* *}$ \\
Er_Er & $-.367^{* *}$ & $-.410^{* *}$ & $.143^{*}$ & $.232^{* *}$ & $-.288^{* *}$ & $-.139^{*}$ & $.155^{* *}$ & $.545^{* *}$ & $.590^{* *}$ & $.674^{* *}$ \\
\hline
\end{tabular}

Notas: L_Er = Lealtad del empleador; S_Er = Seguridad del empleador; $\mathrm{CP} \_\mathrm{Er}=$ Corto plazo del empleador; Lim_Er = Limitado del empleador; R_Er = Rendimiento del empleador; DI_Er = Desarrollo interno del empleador; Em_Er = Empleabilidad del empleador; D_Er = Desconfianza hacia el empleador; I_Er = Incertidumbre sobre el empleador; Er_Er = Erosión del empleador. L_Edo = Lealtad del empleado; S_Edo = Seguridad del empleado; CP_Edo = Corto plazo del empleado; Lim_Edo = Limitado del empleado; R_Edo = Rendimiento del empleado; DI_Edo = Desarrollo interno del empleado; Em_Edo = Empleabilidad del empleado; $D \_E d o=$ Desconfianza del empleado; I_Edo = Incertidumbre del empleado; Er_Edo = Erosión del empleado. ${ }^{*} p<.05$, ${ }^{\star \star} p<.01,{ }^{\star \star \star} p<.001$. Fuente: Elaboración propia.

Tabla 7. Correlaciones entre las creencias de obligaciones del empleado en la IP

\begin{tabular}{|c|c|c|c|c|c|c|c|c|c|c|}
\hline & L_Edo & S_Edo & CP_Edo & Lim_Edo & R_Edo & DI_Edo & Em_Edo & D_Edo & I_Edo & Er_Edo \\
\hline L_Edo & 1 & & & & & & & & & \\
\hline S_Edo & $.581^{\star *}$ & 1 & & & & & & & & \\
\hline CP_Edo & $-.176^{\star *}$ & -0.086 & 1 & & & & & & & \\
\hline Lim_Edo & $-.307^{\star \star}$ & $-.250^{\star *}$ & $.176^{\star *}$ & 1 & & & & & & \\
\hline R_Edo & $.585^{\star *}$ & $.439^{* *}$ & $-.208^{* *}$ & $-.268^{* *}$ & 1 & & & & & \\
\hline DI_Edo & $.370^{* *}$ & $.318^{\star *}$ & 0.027 & -0.102 & $.587^{\star *}$ & 1 & & & & \\
\hline Em_Edo & -0.017 & $-.150^{*}$ & $.239^{\star *}$ & 0.05 & $.159^{* *}$ & $.444^{* *}$ & 1 & & & \\
\hline D_Edo & $-.337^{\star \star *}$ & $-.304^{* *}$ & $.296^{\star \star}$ & $.293^{* \star}$ & $-.339^{* *}$ & $-.168^{\star \star}$ & $.124^{*}$ & 1 & & \\
\hline I_Edo & $-.298^{\star *}$ & $-.328^{* *}$ & $.285^{\star *}$ & $.243^{* *}$ & $-.242^{\star *}$ & -0.076 & $.206^{* *}$ & $.692^{* *}$ & 1 & \\
\hline Er_Edo & $-.324^{* *}$ & $-.353^{\star *}$ & $.215^{\star *}$ & $.218^{* *}$ & $-.300^{\star *}$ & $-.159^{* *}$ & $.131^{*}$ & $.608^{* *}$ & $.671^{* *}$ & 1 \\
\hline
\end{tabular}

Notas: L_Edo = Lealtad del empleado; S_Edo = Seguridad del empleado; $C P \_E d o=$ Corto plazo del empleado; Lim_Edo = Limitado del empleado; R_Edo = Rendimiento del empleado; DI_Edo = Desarrollo interno del empleado; Em_Edo = Empleabilidad del empleado; D_Edo = Desconfianza del empleado; I_Edo = Incertidumbre del empleado; Er_Edo = Erosión del empleado. ${ }^{\star} p<.05,{ }^{\star \star} p<.01,{ }^{\star \star \star} p<.001$. Fuente: Elaboración propia. 
Tabla 8. Regresión lineal múltiple por cada factor del contrato psicológico transaccional del empleado en las creencias de obligaciones del empleador en la IP

\begin{tabular}{|c|c|c|}
\hline & $\beta$ & $\mathrm{R}^{2}$ \\
\hline \multicolumn{3}{|c|}{ Variable dependiente } \\
\hline \multicolumn{3}{|l|}{ Corto plazo empleado } \\
\hline \multicolumn{3}{|c|}{ Variables independientesa } \\
\hline Corto plazo empleador & $0.265^{\star * *}$ & \\
\hline Desconfianza empleador & $0.122^{\star}$ & 0.1 \\
\hline \multicolumn{3}{|c|}{ Variable dependiente } \\
\hline \multicolumn{3}{|l|}{ Limitado empleado } \\
\hline \multicolumn{3}{|c|}{ Variables independientesa } \\
\hline Corto plazo empleador & $0.235^{* * *}$ & \\
\hline Seguridad empleador & $-0.217^{* *}$ & \\
\hline Incertidumbre empleador & $0.133^{*}$ & \\
\hline Limitado empleador & $0.113^{*}$ & 0.216 \\
\hline
\end{tabular}

aMétodo de regresión hacia atrás generó nueve (9) modelos, se muestra el último. bMétodo de regresión hacia atrás generó siete (7) modelos, se muestra el último. ${ }^{*} p<.05,{ }^{\star *} p<.01,{ }^{* \star *} p<.001$. Fuente: Elaboración propia.

Tabla 9. Regresión lineal múltiple por cada factor del contrato psicológico relacional del empleado en las creencias de obligaciones del empleador en la IP

$\beta \quad R^{2}$

Variable dependiente

Lealtad empleado

Variables independientes ${ }^{a}$

Seguridad empleador

$0.305^{* * *}$

Lealtad empleador

$0.245^{* * *}$

Corto plazo empleador

$-0.131^{\star \star}$

0.324

Variable dependiente

Seguridad empleado

Variables independientes ${ }^{b}$

Seguridad empleador

$0.391^{* * *}$

Desarrollo interno empleador

$0.213^{* * *}$

0.309

${ }^{a}$ El método de regresión hacia atrás generó ocho (8) modelos, se muestra el último. ${ }^{b} E l$ método de regresión hacia atrás generó nueve (9) modelos, se muestra el último.

${ }^{\star} p<.05,{ }^{* \star} p<.01,{ }^{* * *} p<.001$. Fuente: Elaboración propia.

En el CP balanceado, el modelo con el nivel explicativo más alto fue en los casos en que el empleador provee las condiciones adecuadas para un buen rendimiento, de modo que el empleado mostrará obligaciones de alto rendimiento (tabla 10). 
Tabla 10. Regresión lineal múltiple por cada factor del contrato psicológico balanceado del empleado en las creencias de obligaciones del empleador en la IP

\begin{tabular}{|c|c|c|}
\hline & $\beta$ & $\mathrm{R}^{2}$ \\
\hline \multicolumn{3}{|l|}{ Variable dependiente } \\
\hline \multicolumn{3}{|l|}{ Rendimiento empleado } \\
\hline \multicolumn{3}{|c|}{ Variables independientes ${ }^{\mathrm{a}}$} \\
\hline Rendimiento empleador & $0.308^{* * *}$ & \\
\hline Seguridad empleador & $0.225^{\star * *}$ & \\
\hline Limitado empleador & $0.129^{\star *}$ & 0.308 \\
\hline \multicolumn{3}{|l|}{ Variable dependiente } \\
\hline \multicolumn{3}{|l|}{ Desarrollo interno empleado } \\
\hline \multicolumn{3}{|c|}{ Variables independientes ${ }^{\mathrm{b}}$} \\
\hline Desarrollo interno empleador & $0.337^{\star * *}$ & \\
\hline Limitado empleador & $0.153^{\star *}$ & 0.172 \\
\hline \multicolumn{3}{|l|}{ Variable dependiente } \\
\hline \multicolumn{3}{|l|}{ Empleabilidad empleado } \\
\hline \multicolumn{3}{|c|}{ Variables independientes ${ }^{\mathfrak{c}}$} \\
\hline Corto plazo empleador & $0.264^{* * *}$ & \\
\hline Empleabilidad empleador & $0.249^{* * *}$ & \\
\hline Erosión empleador & $0.181^{\star *}$ & 0.137 \\
\hline
\end{tabular}

aMétodo de regresión hacia atrás generó ocho (8) modelos, se muestra el último. ${ }^{\mathrm{D}}$ Método de regresión hacia atrás generó nueve (9) modelos, se muestra el último. 'Método de regresión hacia atrás generó ocho (8) modelos, se muestra el último. ${ }^{\star} p<.05,{ }^{\star \star} p<.01,{ }^{\star \star \star} p<.001$. Fuente: Elaboración propia.

En la condición transicional, los tres modelos mostraron alto nivel explicativo (tabla 11); el más alto indica que cuando existe la creencia de incertidumbre sobre el compromiso del empleador en el futuro, el empleado también mostrará incertidumbre sobre su propio compromiso.

Con base en los resultados de los análisis de regresión lineal múltiple, se realizaron análisis PATH para poner a prueba modelos interdependientes con base en el modelo teórico de los tipos de CP de la IP. Solamente se encontró un modelo que resultó con un ajuste adecuado (tabla 12). El modelo especificó las obligaciones transaccionales de una relación laboral a corto plazo y desempeño limitado por parte del empleado, con las respectivas obligaciones antecedentes que se identificaron en los análisis de regresión múltiple (figura 3). 
Tabla 11. Regresión lineal múltiple por cada factor del contrato psicológico transicional del empleado en las creencias de obligaciones del empleador en la IP

\begin{tabular}{|c|c|c|}
\hline & $\beta$ & $\mathrm{R}^{2}$ \\
\hline \multicolumn{3}{|c|}{ Variable dependiente } \\
\hline \multicolumn{3}{|l|}{ Desconfianza empleado } \\
\hline \multicolumn{3}{|c|}{ Variables independientes ${ }^{\mathrm{a}}$} \\
\hline Erosión empleador & $0.243^{\star * \star}$ & \\
\hline Incertidumbre empleador & $0.233^{* * *}$ & \\
\hline Rendimiento empleador & $-0.192^{* * *}$ & \\
\hline Corto plazo empleador & $0.096^{*}$ & 0.377 \\
\hline \multicolumn{3}{|c|}{ Variable dependiente } \\
\hline \multicolumn{3}{|l|}{ Incertidumbre empleado } \\
\hline \multicolumn{3}{|c|}{ Variables independientes ${ }^{\mathrm{b}}$} \\
\hline Incertidumbre empleador & $0.428^{* * *}$ & \\
\hline Erosión empleador & $0.248^{\star * *}$ & \\
\hline Corto plazo empleador & $0.103^{*}$ & 0.456 \\
\hline \multicolumn{3}{|c|}{ Variable dependiente } \\
\hline \multicolumn{3}{|l|}{ Erosión empleado } \\
\hline \multicolumn{3}{|c|}{ Variables independientes ${ }^{c}$} \\
\hline Erosión empleador & $0.502^{* * *}$ & \\
\hline Seguridad empleador & $-0.211^{* * *}$ & \\
\hline Incertidumbre empleador & $0.17^{* *}$ & \\
\hline Lealtad empleador & $0.129^{*}$ & 0.489 \\
\hline
\end{tabular}

aMétodo de regresión hacia atrás generó siete (7) modelos, se muestra el último. ${ }^{\mathrm{D}}$ Método de regresión hacia atrás generó ocho (8) modelos, se muestra el último. 'Método de regresión hacia atrás generó siete (7) modelos, se muestra el último. ${ }^{\star} p<.05,{ }^{\star \star} p<.01,{ }^{\star \star \star} p<.001$. Fuente: Elaboración propia.

Tabla 12. Índices de bondad de ajuste de los modelos especificados de las obligaciones del empleado por tipo de contrato psicológico teórico en la IP

\begin{tabular}{cccccccccc}
\hline Modelo & $\mathrm{Ji}^{2}$ & $\mathrm{~g} . \mathrm{l}$. & $\mathrm{p}$ & $\mathrm{ji} / \mathrm{g} . \mathrm{l}$. & $\mathrm{RMSA}$ & $\mathrm{GFI}$ & $\mathrm{CFI}$ & $\mathrm{NFI}$ & $\mathrm{TLI}$ \\
\hline Tcc_Edo & 6.241 & 6 & .397 & 1.040 & 0.012 & .994 & 1 & .988 & .998 \\
R_Edo & 52.25 & 4 & .000 & 13.063 & .204 & .948 & .935 & .931 & .756 \\
B_Edo & 165.548 & 16 & .000 & 10.347 & .180 & .904 & .891 & .883 & .694 \\
Tsi_Edo & 159.881 & 10 & .000 & 15.988 & .228 & 0.884 & .905 & .901 & .659 \\
\hline
\end{tabular}

Notas: Tcc_Edo: Obligaciones transaccionales empleado. R_Edo: Obligaciones relacionales empleado. B_Edo: Obligaciones balanceado empleado. Tsi_Edo: Obligaciones transicionales empleado. El orden de los modelos se muestra por su ajuste. Solamente se tomó en cuenta el modelo teórico transaccional ya que es el que mostró indicadores de bondad de ajuste adecuados. Fuente: Elaboración propia. 


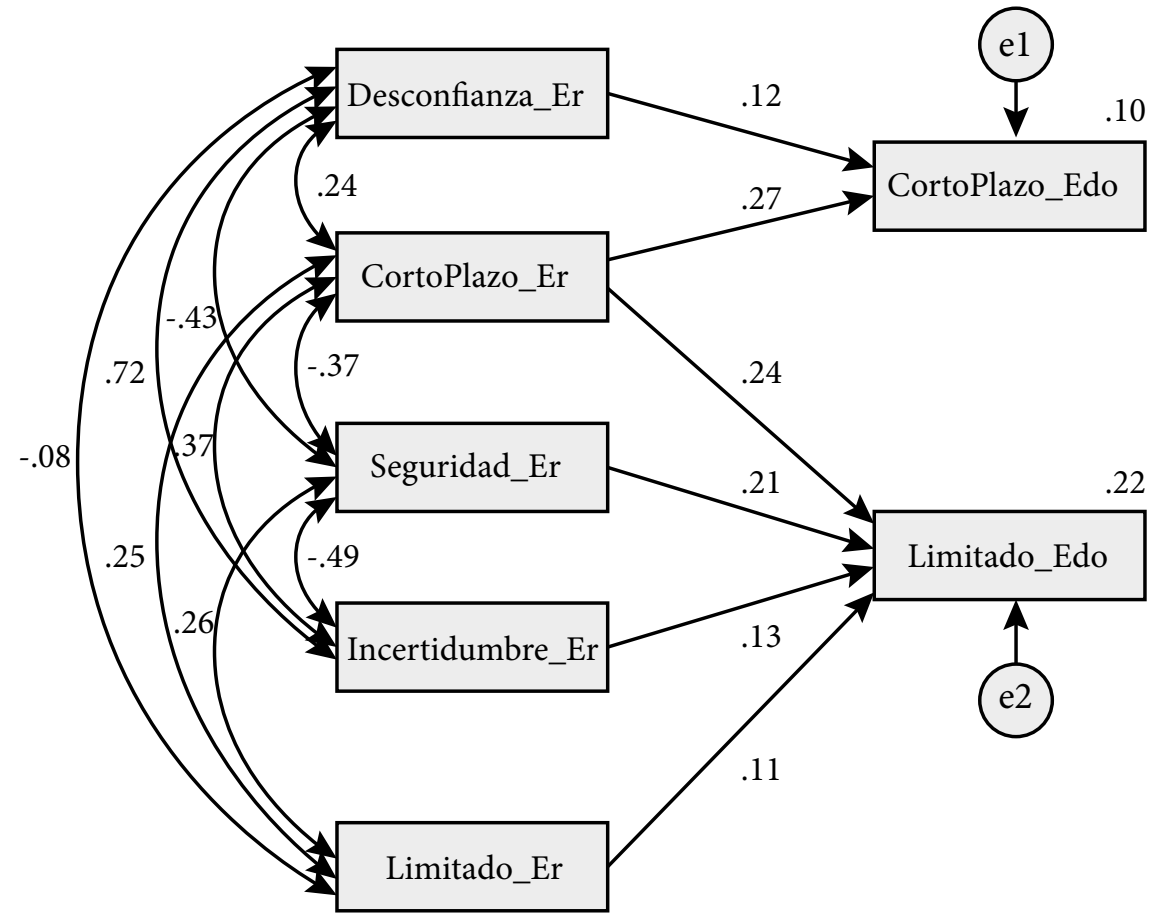

Figura 3. Modelo PATH de las obligaciones transaccionales del empleado en la IP. Fuente: Elaboración propia.

En una interpretación general, podemos señalar por un lado que entre los niveles de las características del contenido del CP de los empleados de la IP está su orientación a desarrollarse en aquellas habilidades que se valoran en el mercado de trabajo, que no tienen claro su compromiso hacia su empleador (tabla 13) y, por otro lado, que la creencia sobre los empleadores es que orientan la relación hacia el desgaste, la incertidumbre, la desconfianza y una relación a corto plazo, lo que puede llevar a que los empleados correspondan, en reciprocidad, con una relación a corto plazo y hacer solamente lo mínimo necesario por lo que le pagan (figura 3).

Respecto a la dinámica del CP en instituciones de gobierno, se encontraron correlaciones estadísticamente significativas entre las obligaciones del empleador y las del empleado en los trabajadores de gobierno (tablas 14-17). A partir de estas correlaciones, se realizaron modelos de regresión lineal múltiple tomando como variable dependiente las obligaciones del empleado para identificar las obligaciones del empleador relacionadas como antecedentes (independientes). 
En el CP transaccional, el modelo que mostró mayor nivel predictivo fue la creencia de que si el empleador muestra lealtad el empleado trabajará de manera limitada solo para lo que lo contrataron (tabla 13).

Tabla 13. Regresión lineal múltiple por cada factor del contrato psicológico transaccional del empleado en las creencias de obligaciones del empleador, en gobierno.

\begin{tabular}{|c|c|c|}
\hline & $\beta$ & $\mathrm{R}^{2}$ \\
\hline \multicolumn{3}{|c|}{ Variable dependiente } \\
\hline \multicolumn{3}{|l|}{ Corto plazo empleado } \\
\hline \multicolumn{3}{|c|}{ Variable independientes ${ }^{\mathrm{a}}$} \\
\hline Rendimiento empleador & $-0.28^{* *}$ & \\
\hline Corto plazo empleador & $0.241^{* * *}$ & \\
\hline Empleabilidad empleador & $0.205^{\star}$ & \\
\hline Limitado empleador & $0.2^{* *}$ & 0.16 \\
\hline \multicolumn{3}{|c|}{ Variable dependiente } \\
\hline \multicolumn{3}{|l|}{ Limitado empleado } \\
\hline \multicolumn{3}{|c|}{ Variables independientes ${ }^{\mathrm{b}}$} \\
\hline Lealtad empleador & $0.441^{* * *}$ & \\
\hline Incertidumbre empleador & $0.403^{* * *}$ & \\
\hline Rendimiento empleador & $-0.295^{* *}$ & \\
\hline Limitado empleador & $0.219^{* *}$ & \\
\hline Corto plazo empleador & $0.165^{\star *}$ & 0.233 \\
\hline
\end{tabular}

aMétodo de regresión hacia atrás generó siete (7) modelos, se muestra el último. ${ }^{b}$ Método de regresión hacia atrás generó 6 modelos, se muestra el último. ${ }^{\star} p<, 05,{ }^{\star \star} p<, 01,{ }^{\star \star \star} p<, 001$. Fuente: Elaboración propia.

Tabla 14. Correlaciones entre las creencias de obligaciones del empleador en gobierno

\begin{tabular}{|c|c|c|c|c|c|c|c|c|c|c|}
\hline & L_Er & S_Er & $\mathrm{CP} \_\mathrm{Er}$ & Lim_Er & R_Er & DI_Er & Em_Er & D_Er & I_Er & Er_Er \\
\hline L_Er & 1 & & & & & & & & & \\
\hline S_Er & $.533^{\star *}$ & 1 & & & & & & & & \\
\hline CP_Er & 0.129 & -0.087 & 1 & & & & & & & \\
\hline Lim_Er & $.398^{* *}$ & $.248^{* *}$ & $.388^{* *}$ & 1 & & & & & & \\
\hline R_Er & $.817^{* *}$ & $.468^{* *}$ & $.189^{* *}$ & $.449^{* *}$ & 1 & & & & & \\
\hline DI_Er & $.738^{* *}$ & $.606^{* *}$ & 0.058 & $.368^{* *}$ & $.787^{* *}$ & 1 & & & & \\
\hline Em_Er & $.659^{* *}$ & $.404^{\star \star}$ & $.340^{* *}$ & $.384^{* \star}$ & $.737^{\star *}$ & $.682^{\star *}$ & 1 & & & \\
\hline D_Er & $-.600^{* *}$ & $-.288^{\star *}$ & 0.116 & -0.118 & $-.476^{\star *}$ & $-.509^{\star *}$ & $-.370^{\star *}$ & 1 & & \\
\hline I_Er & $-.635^{\star *}$ & $-.414^{* *}$ & 0.065 & $-.189^{* *}$ & $-.547^{\star *}$ & $-.549^{\star *}$ & $-.381^{\star *}$ & $.845^{* *}$ & 1 & \\
\hline Er_Er & $-.563^{* *}$ & $-.408^{\star *}$ & 0.079 & -0.069 & $-.459^{* *}$ & $-.474^{* *}$ & $-.326^{\star *}$ & $.754^{* *}$ & $.755^{* *}$ & 1 \\
\hline
\end{tabular}

Notas: L_Er = Lealtad del empleador; S_Er = Seguridad del empleador; $\mathrm{CP} \_\mathrm{Er}=$ Corto plazo del empleador; Lim_Er = Limitado del empleador; R_Er = Rendimiento del empleador; DI_Er = Desarrollo interno del empleador; Em_Er = Empleabilidad del empleador; D_Er = Desconfianza hacia el empleador; I_Er = Incertidumbre sobre el empleador; Er_Er $=$ Erosión del empleador. ${ }^{\star} p<.05,{ }^{* \star} p<.01,{ }^{\star \star \star} p<.001$. Fuente: Elaboración propia. 
Tabla 15. Correlaciones de las creencias de obligaciones del empleador y las obligaciones del empleado en gobierno

\begin{tabular}{ccccccccccc}
\hline & L_Er & S_Er & CP_Er & Lim_Er & R_Er & DI_Er & Em_Er & D_Er & I_Er & Er_Er \\
\hline L_Edo & $.219^{* *}$ & $.203^{* *}$ & 0.044 & 0.044 & $.250^{* *}$ & $.211^{* *}$ & 0.121 & $-.238^{* *}$ & $-.301^{* *}$ & $-.163^{*}$ \\
S_Edo & $.281^{* *}$ & $.388^{* *}$ & -0.062 & 0.003 & $.267^{* *}$ & $.323^{* *}$ & $.182^{* *}$ & $-.216^{* *}$ & $-.238^{* *}$ & $-.245^{* *}$ \\
CP_Edo & 0.016 & -0.05 & $.335^{* *}$ & $.246^{* *}$ & 0.006 & 0.056 & $.157^{*}$ & 0.05 & 0.064 & 0.098 \\
Lim_Edo & 0.052 & 0.062 & $.277^{* *}$ & $.249^{* *}$ & -0.026 & 0.013 & 0.107 & $.180^{*}$ & $.254^{* *}$ & $.194^{* *}$ \\
R_Edo & $.224^{* *}$ & $.262^{* *}$ & 0.093 & 0.129 & $.335^{* *}$ & $.265^{* *}$ & $.283^{* *}$ & -0.088 & -0.124 & -0.052 \\
DI_Edo & $.331^{* *}$ & $.258^{* *}$ & 0.096 & 0.107 & $.340^{* *}$ & $.265^{* *}$ & $.281^{* *}$ & -0.132 & -0.134 & $-.147^{*}$ \\
Em_Edo & 0.094 & 0.103 & $.214^{* *}$ & 0.106 & 0.121 & 0.058 & $.297^{* *}$ & 0.076 & 0.052 & 0.109 \\
D_Edo & $-.509^{* *}$ & $-.363^{* *}$ & 0.075 & -0.07 & $-.456^{* *}$ & $-.416^{* *}$ & $-.302^{* *}$ & $.676^{* *}$ & $.752^{* *}$ & $.719^{* *}$ \\
I_Edo & $-.580^{* *}$ & $-.466^{* *}$ & 0.036 & -0.114 & $-.500^{* *}$ & $-.471^{* *}$ & $-.363^{* *}$ & $.636^{* *}$ & $.701^{* *}$ & $.700^{* *}$ \\
Er_Edo & $-.495^{* *}$ & $-.446^{* *}$ & 0.065 & 0.031 & $-.372^{* *}$ & $-.380^{* *}$ & $-.246^{* *}$ & $.598^{* *}$ & $.609^{* *}$ & $.786^{* *}$ \\
\hline
\end{tabular}

Notas: L_Er = Lealtad del empleador; S_Er = Seguridad del empleador; $\mathrm{CP} \_\mathrm{Er}=$ Corto plazo del empleador; Lim_Er = Limitado del empleador; R_Er = Rendimiento del empleador; DI_Er = Desarrollo interno del empleador; Em_Er = Empleabilidad del empleador; D_Er = Desconfianza hacia el empleador; I_Er = Incertidumbre sobre el empleador; Er_Er = Erosión del empleador. L_Edo = Lealtad del empleado; S_Edo = Seguridad del empleado; $\mathrm{CP}_{-} E d o$ = Corto plazo del empleado; Lim_Edo = Limitado del empleado; R_Edo = Rendimiento del empleado; DI_Edo = Desarrollo interno del empleado; Em_Edo = Empleabilidad del empleado; D_Edo = Desconfianza del empleado; I_Edo = Incertidumbre del empleado; Er_Edo = Erosión del empleado. ${ }^{*} p<.05$, ${ }^{\star *} p<.01,{ }^{* * *} p<.001$. Fuente: Elaboración propia.

Tabla 16. Correlaciones de las creencias de obligaciones del empleado y las obligaciones del empleador en gobierno

\begin{tabular}{ccccccccccc}
\hline & L_Edo & S_Edo & CP_Edo & Lim_Edo & R_Edo & DI_Edo & Em_Edo & D_Edo & I_Edo & Er_Edo \\
\hline L_Er & $.219^{* *}$ & $.281^{* *}$ & 0.016 & 0.052 & $.224^{* *}$ & $.331^{* *}$ & 0.094 & $-.509^{* *}$ & $-.580^{* *}$ & $-.495^{* *}$ \\
S_Er & $.203^{* *}$ & $.388^{* *}$ & -0.05 & 0.062 & $.262^{* *}$ & $.258^{* *}$ & 0.103 & $-.363^{* *}$ & $-.466^{* *}$ & $-.446^{* *}$ \\
CP_Er & 0.044 & -0.062 & $.335^{* *}$ & $.277^{* *}$ & 0.093 & 0.096 & $.214^{* *}$ & 0.075 & 0.036 & 0.065 \\
Lim_Er & 0.044 & 0.003 & $.246^{* *}$ & $.249^{* *}$ & 0.129 & 0.107 & 0.106 & -0.07 & -0.114 & 0.031 \\
R_Er & $.250^{* *}$ & $.267^{* *}$ & 0.006 & -0.026 & $.335^{* *}$ & $.340^{* *}$ & 0.121 & $-.456^{* *}$ & $-.500^{* *}$ & $-.372^{* *}$ \\
DI_Er & $.211^{* *}$ & $.323^{* *}$ & 0.056 & 0.013 & $.265^{* *}$ & $.265^{* *}$ & 0.058 & $-.416^{* *}$ & $-.471^{* *}$ & $-.380^{* *}$ \\
Em_Er & 0.121 & $.182^{* *}$ & $.157^{*}$ & 0.107 & $.283^{* *}$ & $.281^{* *}$ & $.297^{* *}$ & $-.302^{* *}$ & $-.363^{* *}$ & $-.246^{* *}$ \\
D_Er & $-.238^{* *}$ & $-.216^{* *}$ & 0.05 & $.180^{*}$ & -0.088 & -0.132 & 0.076 & $.676^{* *}$ & $.636^{* *}$ & $.598^{* *}$ \\
I_Er & $-.301^{* *}$ & $-.238^{* *}$ & 0.064 & $.254^{* *}$ & -0.124 & -0.134 & 0.052 & $.752^{* *}$ & $.701^{* *}$ & $.609^{* *}$ \\
Er_Er & $-.163^{*}$ & $-.245^{* *}$ & 0.098 & $.194^{* *}$ & -0.052 & $-.147^{*}$ & 0.109 & $.719^{* *}$ & $.700^{* *}$ & $.786^{* *}$ \\
\hline
\end{tabular}

Notas: L_Er = Lealtad del empleador; S_Er = Seguridad del empleador; $\mathrm{CP}_{-} E r$ = Corto plazo del empleador; Lim_Er = Limitado del empleador; R_Er = Rendimiento del empleador; DI_Er = Desarrollo interno del empleador; Em_Er = Empleabilidad del empleador; D_Er = Desconfianza hacia el empleador; I_Er = Incertidumbre sobre el empleador; Er_Er = Erosión del empleador. L_Edo = Lealtad del empleado; S_Edo = Seguridad del empleado; $\mathrm{CP}_{-} E d o=$ Corto plazo del empleado; Lim_Edo = Limitado del empleado; R_Edo = Rendimiento del empleado; DI_Edo = Desarrollo interno del empleado; Em_Edo = Empleabilidad del empleado; D_Edo = Desconfianza del empleado; I_Edo = Incertidumbre del empleado; Er_Edo = Erosión del empleado. ${ }^{*} p<.05$, ${ }^{\star *} p<.01,{ }^{* * *} p<.001$. Fuente: Elaboración propia. 
Tabla 17. Correlaciones entre las creencias de obligaciones del empleado en gobierno

\begin{tabular}{ccccccccccc}
\hline & L_Edo & S_Edo & CP_Edo & Lim_Edo & R_Edo & DI_Edo & Em_Edo & D_Edo & I_Edo & Er_Edo \\
\hline L_Edo & 1 & & & & & & & & & \\
S_Edo & $.436^{* *}$ & 1 & & & & & & & & \\
CP_Edo & -0.074 & -0.07 & 1 & & & & & & & \\
Lim_Edo & $-.379^{* *}$ & -0.086 & $.416^{* *}$ & 1 & & & & & & \\
R_Edo & $.591^{* *}$ & $.361^{* *}$ & -0.078 & $-.231^{* *}$ & 1 & & & & & \\
DI_Edo & $.436^{* *}$ & $.348^{* *}$ & 0.104 & -0.047 & $.460^{* *}$ & 1 & & & & \\
Em_Edo & 0.09 & $-.169^{*}$ & $.261^{* *}$ & $.206^{* *}$ & $.267^{* *}$ & $.348^{* *}$ & 1 & & & \\
D_Edo & $-.262^{* *}$ & $-.268^{* *}$ & $.169^{*}$ & $.276^{* *}$ & -0.115 & $-.214^{* *}$ & 0.019 & 1 & & \\
I_Edo & $-.238^{* *}$ & $-.285^{* *}$ & $.187^{* *}$ & $.210^{* *}$ & -0.094 & $-.165^{*}$ & 0.06 & $.799^{* *}$ & 1 & \\
Er_Edo & -0.123 & $-.246^{* *}$ & 0.092 & 0.065 & 0.016 & $-.152^{*}$ & -0.043 & $.701^{* *}$ & $.641^{* *}$ & 1 \\
\hline
\end{tabular}

Notas: L_Edo = Lealtad del empleado; S_Edo = Seguridad del empleado; $C P \_E d o=$ Corto plazo del empleado; Lim_Edo = Limitado del empleado; R_Edo = Rendimiento del empleado; DI_Edo = Desarrollo interno del empleado; Em_Edo = Empleabilidad del empleado; D_Edo = Desconfianza del empleado; I_Edo = Incertidumbre del empleado; Er_Edo = Erosión del empleado. ${ }^{*} p<.05,{ }^{* \star} p<.01,{ }^{\star \star *} p<.001$. Fuente: Elaboración propia.

En el CP relacional, el modelo con mayor nivel explicativo fue la creencia de que si el empleador ofrece seguridad y estabilidad de la relación laboral el empleado mostrará seguridad de permanencia (tabla 18).

Tabla 18. Regresión lineal múltiple por cada factor del contrato psicológico relacional del empleado en las creencias de obligaciones del empleador en gobierno

\begin{tabular}{ccc}
\hline & $\beta$ & $\mathrm{R}^{2}$ \\
\hline Variable dependiente & & \\
$\quad$ Lealtad Empleado & & \\
Variable independientesa & $-0.301^{* * *}$ & 0.086 \\
Incertidumbre Empleador & & \\
Variable dependiente & & \\
Seguridad Empleado & & \\
Variable independientesb & $0.344^{* * *}$ & \\
Seguridad Empleador & $0.18^{*}$ & 0.181 \\
Rendimiento empleador & $-0.163^{*}$ & \\
Limitado Empleador &
\end{tabular}

aMétodo de regresión hacia atrás generó 10 modelos, se muestra el último. ${ }^{b}$ Método de regresión hacia atrás generó ocho (8) modelos, se muestra el último. ${ }^{*} p<, 05,{ }^{\star \star} p<, 01,{ }^{\star \star *} p<, 001$. Fuente: Elaboración propia.

En el CP balanceado, el modelo con mayor nivel explicativo fue aquel en el que si el empleador ofrece oportunidades para desarrollar habilidades que valora el mercado de trabajo, los empleados corresponderán esforzándose por desarrollar habilidades que se valoran en el mercado de trabajo (tabla 19). 
Tabla 19. Regresión lineal múltiple por cada factor del contrato psicológico balanceado del empleado en las creencias de obligaciones del empleador en gobierno

\begin{tabular}{|c|c|c|}
\hline & $\beta$ & $\mathrm{R}^{2}$ \\
\hline \multicolumn{3}{|l|}{ Variable dependiente } \\
\hline \multicolumn{3}{|l|}{ Rendimiento del empleado } \\
\hline \multicolumn{3}{|l|}{ Variable independientes $^{\mathrm{a}}$} \\
\hline Rendimiento empleador & $0.331^{* * *}$ & \\
\hline Seguridad empleador & $0.177^{\star}$ & \\
\hline Erosión empleador & $0.172^{\star}$ & 0.148 \\
\hline \multicolumn{3}{|l|}{ Variable dependiente } \\
\hline \multicolumn{3}{|l|}{ Desarrollo interno del empleado } \\
\hline \multicolumn{3}{|l|}{ Variable independientes $^{\mathrm{b}}$} \\
\hline Rendimiento empleador & $0.331^{* * *}$ & 0.116 \\
\hline \multicolumn{3}{|l|}{ Variable dependiente } \\
\hline \multicolumn{3}{|l|}{ Empleabilidad del empleado } \\
\hline \multicolumn{3}{|l|}{ Variable independientes ${ }^{c}$} \\
\hline Empleabilidad del empleador & $0.483^{* * *}$ & \\
\hline Desarrollo interno del empleador & $-0.187^{\star}$ & \\
\hline Erosión del empleador & $0.178^{*}$ & 0.152 \\
\hline
\end{tabular}

${ }^{a}$ Método de regresión hacia atrás generó ocho (8) modelos, se muestra el último. ${ }^{b}$ Método de regresión hacia atrás generó 10 modelos, se muestra el último. 'Método de regresión hacia atrás generó ocho (8) modelos, se muestra el último. ${ }^{\star} p<, 05,{ }^{* \star} p<, 01,{ }^{* \star *} p<, 001$. Fuente: Elaboración propia.

Finalmente, en la condición transicional, los tres modelos mostraron alto nivel explicativo; el más alto fue el que indica la creencia de que si el empleador ha ido desgastando la relación al realizar cambios que han disminuido los beneficios, el empleado esperará recibir cada vez menos beneficios, por lo que podríamos hablar de desesperanza (tabla 20).

Con base en los resultados de los análisis de regresión lineal múltiple, se realizaron análisis PATH para poner a prueba modelos interdependientes con base en el modelo teórico de los tipos de $\mathrm{CP}$ en el gobierno. Aunque algunos de los modelos mostraron índices de bondad de ajuste aceptables, no se aceptó ninguno (tabla 21), ya que el valor máximo del índice RMSEA para aceptar un modelo es de 0.08 (Schreiber et ál., 2006).

Hasta ahora, los resultados nos muestran que existen algunas diferencias entre las características del CP entre los trabajadores de la IP y los de gobierno. También hemos identificado que, excepto las obligaciones transaccionales del empleado en la IP, en nuestra muestra no se ajustan los modelos teóricos propuestos por Rousseau (1995) sobre la relación entre los factores de cada tipo de CP. Por tanto, para explorar si existe una estructura subyacente particular (Hair, 1999) del contenido del CP para 
Tabla 20. Regresión lineal múltiple por cada factor la condición transicional del empleado en las creencias de obligaciones del empleador en gobierno

\begin{tabular}{|c|c|c|}
\hline & $\beta$ & $\mathrm{R}^{2}$ \\
\hline \multicolumn{3}{|c|}{ Variable dependiente } \\
\hline \multicolumn{3}{|l|}{ Desconfianza del empleado } \\
\hline \multicolumn{3}{|c|}{ Variable independientes $^{a}$} \\
\hline Incertidumbre empleador & $0.486^{* * *}$ & \\
\hline Erosión empleador & $0.352^{* * *}$ & 0.619 \\
\hline \multicolumn{3}{|c|}{ Variable dependiente } \\
\hline \multicolumn{3}{|l|}{ Incertidumbre del empleado } \\
\hline \multicolumn{3}{|c|}{ Variable independientes ${ }^{b}$} \\
\hline Incertidumbre empleador & $0.359^{* * *}$ & \\
\hline Erosión empleador & $0.35^{\star * *}$ & \\
\hline Seguridad empleador & $-0.171^{\star * *}$ & 0.583 \\
\hline \multicolumn{3}{|c|}{ Variable dependiente } \\
\hline \multicolumn{3}{|l|}{ Erosión empleado } \\
\hline \multicolumn{3}{|c|}{ Variable independientes $^{c}$} \\
\hline Erosión empleador & $0.719^{* * *}$ & \\
\hline Seguridad empleador & $-0.183^{\star * *}$ & \\
\hline Limitado empleador & $0.126^{* *}$ & 0.651 \\
\hline
\end{tabular}

aMétodo de regresión hacia atrás generó nueve (9) modelos, se muestra el último. ${ }^{b}$ Método de regresión hacia atrás generó ocho (8) modelos, se muestra el último. 'Método de regresión hacia atrás generó ocho (8) modelos, se muestra el último. ${ }^{*} p<, 05,{ }^{* \star} p<, 01,{ }^{* *} p<, 001$. Fuente: Elaboración propia.

Tabla 21. Índices de bondad de ajuste de los modelos especificados de las obligaciones del empleado por tipo de contrato psicológico teórico en el gobierno

\begin{tabular}{cccccccccc}
\hline Modelo & Ji $^{2}$ & g.l. & P & ji²/g.l. $^{2}$ & RMSA & GFI & CFI & NFI & TLI \\
\hline Tcc_Edo & 26.147 & 5 & .000 & 5.229 & .145 & .970 & .969 & .963 & .828 \\
B_Edo & 63.810 & 11 & .000 & 5.801 & .154 & .922 & .919 & .906 & .793 \\
R_Edo & 35.281 & 5 & .000 & 7.056 & .173 & .950 & .883 & .871 & .648 \\
Tsi_Edo & 90.346 & 8 & .000 & 11.293 & .226 & .893 & .907 & .900 & .756 \\
\hline
\end{tabular}

Notas: Tcc_Edo: Obligaciones transaccionales empleado. B_Edo: Obligaciones balanceado empleado. R_Edo: Obligaciones relacionales empleado. Tsi_Edo: Obligaciones transicionales empleado. El orden de los modelos se muestra por su ajuste. No se consideró ninguno de los modelos ya que no mostraron índices de bondad de ajuste adecuados. Fuente: Elaboración propia.

cada tipo de organización, proponemos un análisis factorial exploratorio (AFE) de las subescalas de las obligaciones de los empleados, para aproximarnos de manera empírica a la configuración del contenido del CP en organizaciones de la IP y del gobierno.

En la IP, el AFE arrojó un modelo de tres componentes (tabla 22). El segundo componente mostró correspondencia con la condición transicional teórica. Tomando en 
cuenta los análisis de regresión lineal múltiple, se especificaron tres modelos PATH, cada uno con los elementos del AFE; sin embargo, ninguno de los tres modelos mostró un ajuste adecuado (tabla 23).

Tabla 22. AFE de las subescalas de las obligaciones de los empleados, en la IP

\begin{tabular}{|c|c|c|c|}
\hline & \multicolumn{3}{|c|}{ Componente } \\
\hline & 1 & $2^{\mathrm{a}}$ & 3 \\
\hline Lealtad & .829 & -.168 & .045 \\
\hline Seguridad & .757 & -.177 & -.071 \\
\hline Rendimiento & .742 & -.210 & .345 \\
\hline Limitado & -.498 & .175 & .171 \\
\hline Incertidumbre & -.164 & .875 & .129 \\
\hline Desconfianza & -.231 & .842 & .026 \\
\hline Erosión & -.200 & .833 & .006 \\
\hline Empleabilidad & -.083 & .092 & .867 \\
\hline Desarrollo interno & .491 & -.103 & .720 \\
\hline Corto plazo & -.264 & .297 & .401 \\
\hline$\%$ de la varianza & 36.149 & 18.521 & 10.449 \\
\hline Autovalores & 3.615 & 1.852 & 1.045 \\
\hline
\end{tabular}

Notas: Método de extracción: análisis de componentes principales. Método de rotación: Varimax con normalización Kaiser. La rotación ha convergido en cinco (5) iteraciones. En negrillas se muestras las agrupaciones por

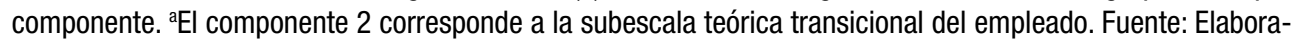
ción propia.

Tabla 23. Índices de bondad de ajuste de los modelos especificados a partir de las agrupaciones empíricas (tabla X) en la IP

\begin{tabular}{cccccccccc}
\hline Model0 & $\mathrm{Ji}^{2}$ & $\mathrm{~g} . \mathrm{I}$. & $\mathrm{p}$ & $\mathrm{ji}^{2} / \mathrm{g} . \mathrm{I}$. & $\mathrm{RMSA}$ & $\mathrm{GFI}$ & $\mathrm{CFI}$ & $\mathrm{NFI}$ & $\mathrm{TLI}$ \\
\hline Componente 3 & 78.525 & 14 & .000 & 5.609 & .126 & .948 & .917 & .904 & .787 \\
Componente 1 & 139.131 & 23 & .000 & 6.049 & .132 & .917 & .928 & .916 & .827 \\
Componente 2 & 159.881 & 10 & .000 & 15.988 & .228 & 0.884 & .905 & .901 & .659 \\
\hline
\end{tabular}

Nota: El orden de los modelos se muestra por su ajuste. Fuente: Elaboración propia.

En el gobierno, el AFE arrojó tres componentes (tabla 24). El primer componente corresponde con la condición transicional teórica. Tomando en cuenta los análisis de regresión lineal múltiple, se especificaron tres modelos $\mathrm{PATH}$, cada uno con los elementos del AFE. El modelo especificado con los elementos del componente 3: corto plazo, limitado y empleabilidad, mostró un ajuste aceptable (tabla 25).

En la figura 4 se muestra el modelo especificado en el que se indica con línea punteada que dos de los tres componentes corresponden al CP transaccional teórico. $\mathrm{Al}$ agregar la empleabilidad, con base en el AFE, se encuentra una estructura subyacente 
Tabla 24. AFE de las subescalas de las obligaciones de los empleados en gobierno

\begin{tabular}{|c|c|c|c|}
\hline & \multicolumn{3}{|c|}{ Componente } \\
\hline & $1^{\mathrm{a}}$ & $2^{\mathrm{a}}$ & 3 \\
\hline Desconfianza & .896 & -.176 & .128 \\
\hline Erosión & .883 & -.020 & -.053 \\
\hline Incertidumbre & .878 & -.137 & .144 \\
\hline Rendimiento & .067 & .851 & .002 \\
\hline Lealtad & -.114 & .823 & -.162 \\
\hline Desarrollo interno & -.162 & .711 & .340 \\
\hline Seguridad & -.278 & .546 & -.135 \\
\hline Corto plazo & .102 & -.059 & .740 \\
\hline Limitado & .089 & -.349 & .703 \\
\hline Empleabilidad & .015 & .294 & .692 \\
\hline$\%$ de la varianza & 31.789 & 19.494 & 15.549 \\
\hline Autovalores & 3.179 & 1.949 & 1.555 \\
\hline
\end{tabular}

Notas: Método de extracción: análisis de componentes principales. Método de rotación: Varimax con normalización Kaiser. La rotación ha convergido en 4 iteraciones. En negrillas se muestras las agrupaciones por com-

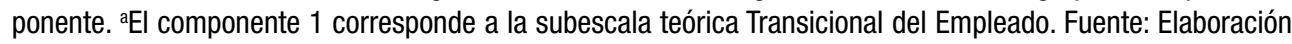
propia.

Tabla 25. Índices de bondad de ajuste de los modelos especificados a partir de las agrupaciones empíricas (tabla X) en el gobierno

\begin{tabular}{cccccccccc}
\hline Modelo & Ji2 & g.l. & $\mathrm{p}$ & $\mathrm{ji} / \mathrm{g} . \mathrm{l}$. & $\mathrm{RMSA}$ & $\mathrm{GFI}$ & $\mathrm{CFI}$ & $\mathrm{NFI}$ & $\mathrm{TLI}$ \\
\hline Componente 3 & 42.718 & 18 & .001 & 2.373 & .082 & .962 & .978 & .964 & .933 \\
Componente 1 & 90.346 & 8 & .000 & 11.293 & .226 & .893 & .907 & .900 & .756 \\
Componente 2 & 177.514 & 19 & .000 & 9.343 & .203 & .819 & .744 & .729 & .514 \\
\hline
\end{tabular}

El orden de los modelos se muestra por su ajuste. Fuente: Elaboración propia.

significativa en la configuración del contrato psicológico de los trabajadores del gobierno de esta muestra.

En una interpretación general sobre los trabajadores del gobierno, con base en los análisis de regresión lineal múltiple y el modelo PATH empírico, la configuración significativa de contenido de CP del empleado incluyó los dos elementos transaccionales y la empleabilidad del tipo balanceado; esto implica que los empleados se desempeñan de manera limitada, con una perspectiva de relación a corto plazo y énfasis en desarrollar habilidades que se valoran en el mercado de trabajo. Podríamos interpretar que los empleados de gobierno consideran que su relación puede ser tan limitada y a corto plazo que necesariamente se deben enfocar en estar preparados para el momento de buscar trabajo. 


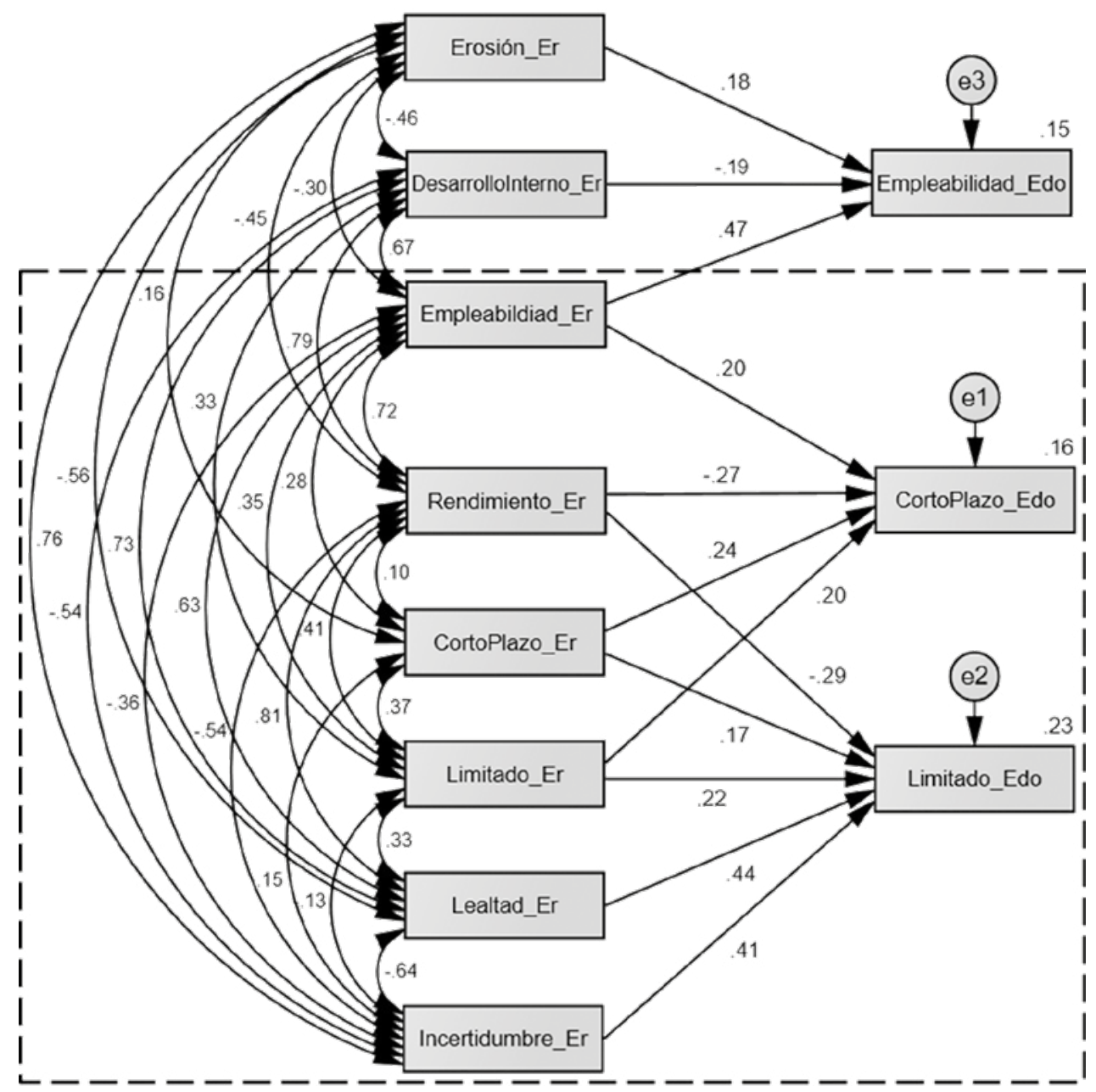

Figura 4. Modelo PATH del modelo empírico especificado del componente 3 (Tabla 25) en el gobierno. La línea punteada indica el alcance de las obligaciones teóricas transaccionales del empleado. Fuente: Elaboración propia.

\section{Discusión y conclusiones}

La validación de constructo es un proceso continuo para aportar evidencia y poner a prueba distintas hipótesis acerca de su estructura interna (Messick, 1995). Partiendo de este supuesto psicométrico, nuestro estudio proporciona evidencia sobre la validez y confiabilidad del inventario de contrato psicológico en población mexicana como un elemento más en la investigación de este constructo en diferentes contextos socioculturales y organizacionales (Thomas, Au \& Ravlin, 2003). 
Los resultados de este estudio muestran una dinámica instrumental de las relaciones laborales en México, en la cual los trabajadores mexicanos tienen la preocupación principal por aspectos transaccionales y por estar preparados para emplearse, ya que tienen incertidumbre sobre la relación laboral, muestran desesperanza al considerar que han ido perdiendo beneficios, desconfían de su empleador y consideran que la relación laboral puede terminar en cualquier momento; es decir, los empleados de esta muestra no consideran que exista seguridad del empleo. En particular, podemos señalar que los cambios en las prácticas de las relaciones laborales en los nuevos gobiernos, como los despidos masivos de empleados de confianza en el gobierno, contratos menos protegidos y bajo condiciones desfavorables (Guzmán, 2019; Miranda, 2019; Navarro, 2018), pueden aportar información sobre el contexto laboral y social y sobre los resultados del modelo de contrato psicológico en el gobierno que resultó en esta investigación.

La Organización Internacional del Trabajo - OIT (2012) señala que el trabajo precario comprende dos categorías: a) los arreglos contractuales, que implican tanto una duración limitada del contrato (plazo fijo, corto plazo, temporal, estacional, trabajo a jornal y empleo ocasional), como la naturaleza de la relación laboral (triangulares, encubiertas, falso autónomo, agencias o subcontratistas); y b) las condiciones precarias, que contemplan salario bajo, escasa protección frente al despido, falta de acceso a la protección social y la posibilidad limitada o nula de ejercer los derechos laborales. Este tipo de relaciones laborales puede generar riesgos psicosociales que afectarán de manera negativa la salud (física, mental y social) de los trabajadores en México (Martínez-Mejía, 2016).

Desde la década de los setenta, México comenzó un proceso de ajuste y reestructuración de su economía y la regulación que acompañó al ámbito laboral, combinada con la expansión de la industria maquiladora de exportación en los ochenta, que se formalizó en los noventa (Anguiano y Ortiz, 2013). Según De la O y Quintero (2001), este enfoque económico ha ido introduciendo un modelo de relaciones laborales y de sindicalismo que protegió la degradación de las relaciones laborales, incluyendo lo que estos autores señalan como contratación simulada, es decir, la figura legalizada de subcontratación o outsourcing, estableciendo las bases para una flexibilización y precarización generalizada del trabajo que se concreta con la última reforma laboral en 2012 (Anguiano \& Ortiz, 2013; Reyes, 2016). Al respecto, Hernández (2016) señala que todos estos cambios del marco normativo laboral hacia la flexibilidad laboral han vulnerado el trabajo, al no contar con los mecanismos de protección social, desprotegiendo los derechos fundamentales del trabajo. 
Desde este panorama de las relaciones laborales en México, podemos señalar las principales leyes, reglamentos y normas relacionadas con el trabajo y algunos de los cambios y reformas que han tenido; con base en el artículo 123 de la Constitución Política de los Estados Unidos Mexicanos (1917/2018) se desprenden dos leyes federales relacionadas con el trabajo y la previsión social: la Ley Federal del Trabajo (1970/2018) (LFT), que tuvo su última gran reforma en 2012, y la Ley Federal de los Trabajadores al Servicio del Estado (1963/2018) (LFTSE); además, respecto al gobierno, también podemos mencionar las actualizaciones a la Ley Orgánica de la Administración Pública Federal en 2018 y sus implicaciones para las relaciones laborales, así como las leyes sobre seguridad social y en las últimas reformas de mayor impacto: la Ley del Instituto Mexicano del Seguro Social (LIMSS) en 1995 y la Ley del Instituto de Seguridad y Servicios Sociales de los Trabajadores del Estado (LISSSTE) en 2007. Además, derivado de los aspectos de salud de la LFT, está el Reglamento Federal de Seguridad y Salud en el Trabajo con la subsecuente reforma en 2014, así como la actualización y generación de diversas normas oficiales mexicanas sobre seguridad, salud y riesgos laborales como, por ejemplo, la NOM-030-STPS-2009Servicios preventivos de seguridad y salud, la NOM-019-STPS-2011-Comisiones de seguridad e higiene, entre otras, y nuevas normas como la NOM-035-STPS-2018Factores de riesgo psicosocial en el trabajo.

Todas estas actualizaciones y cambios legales han impactado las relaciones laborales en diversos sentidos, por ejemplo, la diversidad de los tipos de contratos que se pueden realizar tanto en la IP como en el gobierno (LFT 1970/2018; LFTSE, 1963/2018); cambios en los beneficios en el sistema de ahorro para el retiro tanto para los trabajadores de la IP (LIMSS, 1995) como del gobierno (LISSSTE, 2007); las características para la intermediación y subcontratación de trabajadores (LFT, 1970/2018); y ajustes en los riesgos y enfermedades de trabajo (Reglamento Federal de Seguridad y Salud en el Trabajo - RFSST, 2014). Respecto al gobierno, además, habría que sumar los cambios en los estilos de gestión pública generados por la entrada de nuevos gobiernos federales cada seis años; en este contexto, como mostramos en este estudio, las relaciones laborales en México parecen no tener un impacto positivo (relacional o balanceado) en el contenido del contrato psicológico de trabajadores tanto de la iniciativa privada como del gobierno.

Una de las limitaciones de este estudio es que se trata de un estudio transversal y con un tipo de muestreo no probabilístico, por lo que se propone realizar estudios con muestras más amplias y muestreos que aumenten la solidez metodológica. Por otro lado, parece necesario seguir explorando de manera cualitativa el contenido del $\mathrm{CP}$ para proponer elementos alternativos que complementen la explicación de la relación de intercambio empleador-empleado con mayor amplitud (Alcover, Rico, 
Turnley y Bolino 2017b), en particular en México y Latinoamérica, ya que la realidad de las relaciones laborales puede ser distinta en comparación con otros países y puede ampliar o modificar el contenido del CP.

El estudio del contrato psicológico en el marco de las relaciones de intercambio en las organizaciones aporta una sólida aproximación a la comprensión de la relación empleador-empleado, que puede ayudar a las organizaciones y sus directivos a tomar decisiones más acertadas y efectivas en la gestión de sus colaboradores, reduciendo la incertidumbre y la desconfianza y aportando mayores beneficios a los trabajadores, no solo materiales sino socioafectivos, para generar relaciones laborales sanas y productivas.

\section{Referencias}

Alcover, C. M. (2002). El contrato psicológico. El componente implícito de las relaciones laborales. Ediciones Aljibe.

Alcover, C. M. \& Martínez-Íñigo, D. (2005). Adaptación en una muestra española del Psychological Contract Inventory (PCI) de Rousseau. (Documento de trabajo inédito). Universidad Rey Juan Carlos.

Alcover, C. M., Rico, R., Turnley, W. H. \& Bolino, M. C. (2017a). Understanding the changing nature of psychological contracts in 21st century organizations: A multiple-foci exchange relationships approach and proposed framework. Organizational Psychology Review, 7(1), 4-35.

Alcover, C. M., Rico, R., Turnley, W. H. \& Bolino, M. C. (2017b). Multi-dependence in the formation and development of the distributed psychological contract. European Journal of Work and Organizational Psychology, 26(1), 16-29.

Anguiano, A. \& Ortiz, R. (2013). Reforma laboral en México: precarización generalizada del trabajo. El Cotidiano, 182, 95-104.

Argyris, C. (1960). Understanding organizational behavior. Tavistock Publications.

Aseagle J. \& Eisenberger R. (2003) Percibed organizational support and psychological contracts: A theoretical integration. Journal of Organizational Behavior, 24(5), 491-509.

Baruch. Y. \& Rousseau, D. M. (2018). Integrating psychological contracts and ecosystems in career studies and management. Academy of Management Annals. (En prensa).

Blau, P. M. (1964). Intercambio y poder en la vida social. John Wiley \& Sons.

Constitución Política de los Estados Unidos Mexicanos (1917). Diario Oficial de la Federación. Última reforma publicada 27-08-2018. http://www.diputados.gob.mx/LeyesBiblio/pdf/1_270818.pdf

Coyle-Shapiro, J. A.-M., Costa, S. P., Doden, W. \& Chang, C. (2019). Psychological contracts: past, present, and future. Annual Review of Organizational Psychology and Organizational Behavior, 6, 1-25. 
Coyle-Shapiro, J. A-M \& Conway, C. (2005) Exchange relationships: examining psychological contracts and perceived organizational support. Journal of Applied Psychology, 90(4), 774-781.

De la O, M. E. \& Quintero, C. (2001). Globalización, trabajo y maquilas: las nuevas y viejas fronteras en México. Plaza y Valdés.

Díaz-Saenz, H. \& Witherspoon, P. (2000). Historical, familial, and contemporary influences on work relationships. En: D. Rousseau \& R. Shalk, Psychological contracts in employment: cross-national perspectives (pp. 158-175). Sage.

Eisenberger, R., Huntington, R., Hutchison, S. \& Sowa, D. (1986). Perceived organizational support. Journal of Applied Psychology, 71, 500-507.

Freese, C. \& Schalk, R. (2008). How to measure the psychological contract? A critical criteria-based review of measures. South African Journal of Psychology, 38(2), 269-286.

Gould, S. (1979). An equity-exchange model of organizational involvement. Academy of Management Review, 4, 53-62.

Gouldner, A. W. (1960) The norm of reciprocity. A preliminary statement. American Sociological Review, 25, 161-178.

Gracia, F. G., Peiró, J. M. \& Mañas, M. A. (2007). El contrato psicológico en la Administración Pública: derechos y obligaciones del empleado público desde su propia perspectiva. Revista de Psicología del Trabajo y de las Organizaciones, 23, 389-418.

Guzmán, S. (2019). A 38 días, despedirían a 12 mil 817 trabajadores. El Financiero. http:// elfinanciero.com.mx/nacional/en-38-dias-12-mil-817-trabajadores-despedidos-o-envias-de-serlo

Hair, J. F., Anderson, R. E., Tatham, R. L. \& Black, W. C. (1999). Análisis multivariante. Prentice Hall.

Hernández, A. (2016). Desregulación y flexibilidad: rutas jurídicas para precarizar el trabajo en México. En: J. A. Bouzas (ed.). Relaciones laborales reales vs. formales: el mundo del trabajo en México y otras latitudes (pp. 17-40). Instituto de Investigaciones Económicas-UNAM.

Hernández, R., Fernández, C. \& Baptista, P. (2014). Metodología de la investigación. McGraw-Hill Interamericana.

Homans, G. (1974) Social behavior: its elementary forms. Harcourt Brace Jovanovich.

Hudelson, P. M. (1996). Qualitative research for health programmes. World Health Organization, Division of Mental Health and Prevention of Substance Abuse.

Lévy-Mangin, J. P. \& Varela, J. (2006). Modelización con estructuras de covarianzas en ciencias sociales. Temas esenciales, avanzados y aportaciones especiales. Netbiblo.

Ley del Instituto de Seguridad \& Servicios Sociales de los Trabajadores del Estado (2007). Diario Oficial de la Federación, 31-03-2007. http://www.diputados.gob.mx/LeyesBiblio/ pdf/LISSSTE_220618.pdf 
Ley del Seguro Social (1995). Diario Oficial de la Federación. Última reforma publicada 2206-2018. http://www.diputados.gob.mx/LeyesBiblio/pdf/92_220618.pdf

Ley Federal de los Trabajadores al Servicio del Estado (1963). Diario Oficial de la Federación. Última reforma publicada 22-06-2018. http://www.diputados.gob.mx/LeyesBiblio/ pdf/111_220618.pdf

Ley Federal del Trabajo (1970). Diario Oficial de la Federación, última reforma publicada 22 06-2018. http://www.diputados.gob.mx/LeyesBiblio/pdf/125_220618.pdf

Ley Orgánica de la Administración Pública Federal (1976). Diario Oficial de la Federación. Última reforma publicada 30-11-2018. http://www.diputados.gob.mx/LeyesBiblio/ pdf/153_301118.pdf

Martínez-Mejía, E. (2016). Relaciones de intercambio en las organizaciones y riesgos psicosociales: Un estudio sobre la relación del contrato psicológico y el burnout. En: J. Uribe (ed.). Psicología del trabajo: Un entorno de factores psicosociales saludables para la productividad (pp. 129-138). Manual Moderno.

Martínez-Mejía, E. (2018). Contrato psicológico en empleados mexicanos: Creencias de obligaciones relacionales y transaccionales. Acta de Investigación Psicológica, 8(2), 59-69.

Máynez, A. I., Cavazos, J. \& Reyes, G. (2017). Efecto de la violación del contrato psicológico y el agotamiento emocional sobre el cinismo del empleado. Estudios Gerenciales, 33(143), 124-131.

Messick, S. (1995). Standards of validity and the validity of standards in performance asessment. Educational Measurement: Issues and Practice, 14(4), 5-8.

Miranda, F. (2019). Por austeridad, ISSSTE despide a 3 mil trabajadores. Milenio. 4 de diciembre. http://www.milenio.com/politica/organismos/issste-despide-a-3-mil-trabajadores

Morrison, E. W. \& Robinson, S. L. (1997) When employees feel betrayed: a model of how psychological contract violation develops. Academy of Management Review, 22, 226-256.

Muñiz, J. (1998). La medición de lo psicológico. Psicothema, 10(1), 1-21.

Muñiz, J., Elosua, P. \& Hambleton, R. K. (2013). Directrices para la traducción y adaptación de los tests: segunda edición. Psicothema, 25(2), 151-157. doi: 10.7334/psicothema2013.24

Navarro, M. F. (2018). El SAT no es el único, hay despidos a destajo en dependencias federales. Forbes México. 21 de diciembre. https://www.forbes.com.mx/el-sat-no-es-el-unicohay-despidos-a-destajo-en-dependencias-federales/

NOM-019-STPS-2011-Comisiones de seguridad e higiene. Diario Oficial de la Federación 1604-2011. http://asinom.stps.gob.mx:8145/upload/nom/34.pdf

NOM-030-STPS-2009-Servicios preventivos de seguridad y salud. Diario Oficial de la Federación 22-12-2009. http://asinom.stps.gob.mx:8145/upload/nom/32.pdf

NOM-035-STPS-2018-Factores de riesgo psicosocial en el trabajo. Diario Oficial de la Federación 23-10-2018. https://dof.gob.mx/nota_detalle.php?codigo $=5541828 \&$ fecha $=23$ /10/2018 
Organización Internacional del Trabajo - OIT (2012). Del trabajo precario al trabajo decente: Documento final del simposio de los trabajadores sobre políticas y reglamentación para luchar contra el empleo precario. OIT.

Pérez-Gil, J. A. P., Moscoso, S. C. \& Rodríguez, R. M. (2000). Validez de constructo: el uso de análisis factorial exploratorio-confirmatorio para obtener evidencias de validez. Psicothema, 12(2), 442-446.

Reglamento Federal de Seguridad y Salud en el Trabajo (2014). Diario Oficial de la Federación 13-11-2014. http://www.diputados.gob.mx/LeyesBiblio/regla/n152.pdf

Reyes, G. (2016). La reforma laboral de 2012: realidad y relevancia. En: J. A. Bouzas, Relaciones laborales reales $v$ s. formales: el mundo del trabajo en México y otras latitudes (pp. 97-109). Instituto de Investigaciones Económicas-UNAM.

Rial, A., Varela, J., Abalo, J. \& Lévy, J. (2006). El análisis factorial confirmatorio. En: J.P. Lévy \& J. Varela (coords.). Modelización con estructuras de covarianzas en Ciencias Sociales. Temas esenciales, avanzados y aportaciones especiales (pp. 119-154). Netbiblo.

Rousseau, D. M. (1989). Psychological and implied contract in organizations. Employee Rights and Responsibilities Journal, 2, 121-139.

Rousseau, D. M. (1995). Psychological contracts in organizations. understanding written and unwritten agreements. Sage.

Rousseau, D. M. (2000). Psychological contract inventory technical report. Carnegie Mellon University. http://www.andrew.cmu.edu/user/rousseau/0_reports/reports.html

Rousseau, D. M. (2004). Psychological contracts in the workplace: understanding the ties that motivate. Academy of Management Executive, 18(1), 120-127.

Rousseau, D. M. \& Tijoriwala, S. A. (1998). Assessing psychological contracts: issues, alternatives and measures. Journal of Organizational Behavior: The International Journal of Industrial, Occupational and Organizational Psychology and Behavior, 19, 679-695.

Schreiber, J. B., Stage, F. K., King, J., Nora, A. \& Barlow, E. A. (2006). Reporting structural equation modeling and confirmatory factor analysis results: a review. The Journal of Educational Research, 99(6), 323-337.

Thomas, D. C., Au, K. \& Ravlin, E. C. (2003). Cultural variation and the psychological contract. Journal of Organizational Behavior, 24, 451-471. doi: 10.1002/job.209. 


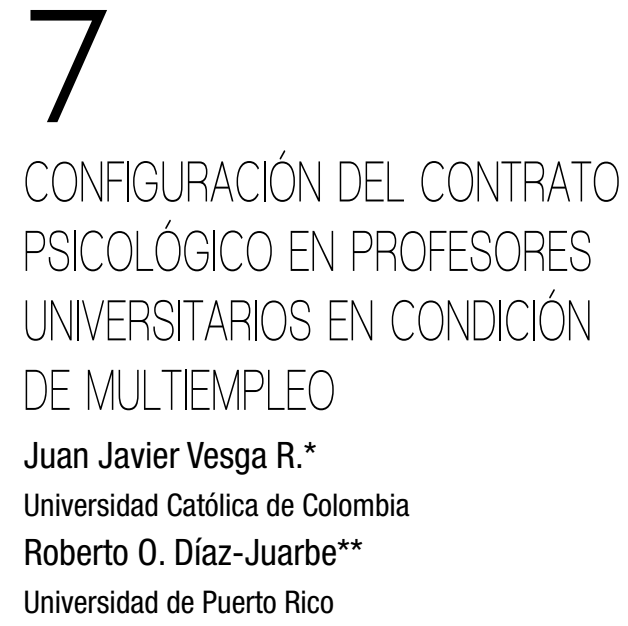

\section{Introducción}

El mundo del trabajo se ha visto fuertemente afectado en las últimas cuatro décadas como resultado de las transformaciones que han estado ocurriendo en la gestión de las organizaciones; estas han incrementado el uso de estrategias como las fusiones, alianzas, creación de redes, simplificación de macroestructuras organizativas y externalización o subcontratación de la fuerza de trabajo, entre otras, como mecanismos para mantener su competitividad en el mercado.

En este contexto, un concepto que ha tomado gran relevancia durante los últimos años para el estudio y comprensión de las relaciones de trabajo es el de contrato psicológico; este concepto ha capturado la atención de los investigadores, como se evidencia por el rápido incremento de artículos publicados sobre el tema (Agarwal, 2014; Conway \& Briner, 2009; Coyle-Shapiro \& Parzefall, 2010); una de las principales razones "es que es considerado como una vía útil de comprensión y quizá de administración de los cambios evidentes de las relaciones de trabajo causados por las nuevas circunstancias económicas y organizacionales" (Conway \& Briner, 2009, p. 7). El contrato psicológico ha sido definido como "las creencias individuales, formadas por la organización, respecto de los términos de un acuerdo de intercambio entre individuos y su organización" (Rousseau, 1995, p. 9). Desde sus orígenes (Argyris, 1960; Levinson, Price, Munden, Mandl \& Solley, 1962), este concepto se delimitó en

\footnotetext{
${ }^{*}$ https://orcid.org/0000-0003-2382-5104

${ }^{* *}$ https://orcid.org/0000-0002-7957-6277
} 
el marco condiciones de trabajo más estables, con vinculación laboral de los trabajadores principalmente como empleados con contrato de trabajo directo con la empresa y carreras laborales fundamentalmente dentro de estas, cuyo desarrollo implicaba el ascenso vertical del empleado en las líneas de mando; sin embargo, actualmente el entorno empresarial y económico se ha vuelto más inestable y la flexibilización en las formas de contratación ha tenido un importante auge, lo que lleva a sugerir una reconsideración en la forma como se ha definido el contrato psicológico.

Para la presente investigación, los autores parten de una redefinición del contrato psicológico más allá de las clásicas definiciones que lo ubican en el plano de lo individual, para situarlo en el plano de las relaciones de trabajo, entendiendo así que el contrato psicológico es una producción simbólico-emocional que emerge ante experiencias vividas en múltiples escenarios relacionales. Por lo tanto, el contrato psicológico comprende la producción de sentidos subjetivos (González, 2007) relacionados con el conjunto de compromisos implícitos por parte de las personas implicadas en una relación de trabajo, que sobrepasan los acuerdos formales establecidos en los contratos jurídicos laborales.

De otra parte, en el actual contexto laboral se observa que las relaciones de trabajo han llegado a un alto nivel de complejidad, pues en muchos casos ya no se limitan a una relación de los trabajadores con un único empleador, y el desarrollo de la carrera profesional no está limitado a una sola organización, ya que se ha pasado "de la supremacía del modelo de un solo empleador a un modelo más complejo de nexos interorganizacionales donde hay múltiples empleadores y clientes" (Grimshaw, Marchington, Rubbery \& Willmott, 2005, p. 2).

En este sentido, un hecho actual de particular importancia en las dinámicas organizacionales y sus correspondientes relaciones de trabajo es el de las relaciones multiempleo, las cuales comprenden el vínculo de trabajo que tiene una persona con más de una organización de manera simultánea, como es el caso de los profesores llamados "hora cátedra" o "catedráticos", que prestan sus servicios de docencia a varias universidades al mismo tiempo, o el de los profesionales de la salud que trabajan por turnos con varios hospitales y clínicas. Esta forma de vinculación laboral, también conocida como pluriempleo, significa que una persona realiza su trabajo con y obtiene sus ingresos de varias organizaciones al mismo tiempo. García-Prado y González (2006) expresan que "el término pluriempleo se define como el desempeño por parte de una persona de más de un trabajo remunerado" (p. 29).

Uno de los ámbitos laborales en los que hay un considerable nivel de formas de vinculación tipo multiempleo es el de la educación superior o universitaria. En relación con la función de docencia, buena parte de estas actividades son llevadas a cabo por 
profesores vinculados en la modalidad de contratos de tiempo parcial, quienes igualmente trabajan para varias universidades en el mismo periodo o son consultores independientes además de profesores universitarios.

En el caso particular de los dos países tenidos en cuenta en el presente estudio, en Puerto Rico, en el periodo 2015-2016, la asignación de profesores de tiempo parcial era del 56 \%, según datos del Consejo de Educación de Puerto Rico (2016). En Colombia, en 2015, los profesores de tiempo parcial y hora cátedra sumaban el $42 \%$ del total de profesores universitarios, según datos del Sistema Nacional de Información de la Educación Superior (2016).

Aunque el contrato psicológico ha sido estudiado en relación con diversas condiciones de trabajo - por ejemplo, el efecto de la contratación de empleados externos o el uso de trabajadores temporales sobre el contrato psicológico (George, 2003), las diferencias en el contenido del contrato psicológico en función del tipo de contrato y del tipo de gestión empresarial pública o privada (Silla, Gracia \& Peiró, 2005), los tipos de contratación laboral y sus implicaciones en el contrato psicológico (Vesga, 2011), la relación entre contrato psicológico y cambio organizacional (García-Rubiano \& Forero-Aponte, 2015) -, la investigación hecha hasta el momento sobre el contrato psicológico en relación con vínculos laborales tipo multiempleo ha sido relativamente escasa, por lo que no existe suficiente literatura y menos actualizada sobre este tópico, ya que tradicionalmente las relaciones de trabajo han sido concebidas involucrando a un solo empleador y a un empleado y se ha asumido tácitamente que los derechos y obligaciones de las partes podrían identificarse al interior de una misma organización (Rubery, Earnshaw \& Marchington, 2005). Sin embargo, es necesario entender que "el crecimiento de las relaciones interorganizacionales incrementa la necesidad de considerar la relación de empleo más allá del lugar específico de trabajo o empresa" (Rubery, Earnshaw \& Marchington, 2005, p. 65). En este orden de ideas, esta investigación se orientó a indagar la manera como se configura el contrato psicológico en profesores universitarios vinculados laboralmente con varias universidades en relaciones de multiempleo.

\section{Método}

Para la realización del estudio se optó por un diseño de estudio de caso, puesto que "los estudios de caso reúnen informaciones tan numerosas y tan detalladas cuanto es posible con miras a aprehender la totalidad de una situación" (De Bruyne, Herman \& De Schoutheete, 1991, pp. 224-225) y, asimismo, es un abordaje usado para generar una comprensión multifacética y en profundidad de un tema complejo en su contexto de la vida real (Crowe et ál., 2011). 


\section{Participantes}

El contrato psicológico ha sido estudiado principalmente desde la perspectiva de los trabajadores, por lo que en este estudio se involucró también a la contraparte, esto es, a los agentes representantes de la organización como son los directivos académicos directamente relacionados con los profesores (decanos o directores de programa).

Por medio de la técnica de sujetos voluntarios, se seleccionó a tres profesores y dos directivos académicos para ser entrevistados en cada una de las ciudades del estudio (San Juan de Puerto Rico y Cali), para un total de seis profesores y cuatro directivos, sin constituir necesariamente un estudio comparativo. Para el primer caso, se seleccionó a profesores universitarios vinculados con contrato de trabajo temporal con más de una universidad en el mismo periodo y con un mínimo de un año en el ejercicio de la actividad docente. Para el segundo caso, se entrevistó a directivos académicos, quienes debían tener a cargo personal docente, incluyendo los profesores hora cátedra, con un año de vinculación por lo menos en el cargo.

\section{Caracterización de los participantes}

El grupo de profesores entrevistados estuvo conformado por cuatro mujeres y dos hombres con edades entre los 33 y los 49 años y nivel de formación de maestría o doctorado, lo cual supone una trayectoria en el campo de la academia y buenos niveles de formación. Tres de los profesores tienen vinculación laboral con dos universidades, dos profesores con tres y solo uno tiene vínculo laboral con cuatro universidades.

Tabla 1. Caracterización del grupo de profesores

\begin{tabular}{|c|c|c|c|c|c|}
\hline País & Sujeto & Edad & Género & $\begin{array}{c}\mathrm{N}^{\circ} \text { de universidades } \\
\text { con que trabaja }\end{array}$ & $\begin{array}{l}\text { Nivel académico } \\
\text { alcanzado }\end{array}$ \\
\hline \multirow{3}{*}{ Puerto Rico } & $\mathrm{P} 01$ & 49 & Femenino & 3 & Doctorado \\
\hline & $\mathrm{P} 02$ & 33 & Masculino & 2 & Maestría \\
\hline & $\mathrm{P} 03$ & 47 & Femenino & 4 & Doctorado \\
\hline \multirow{3}{*}{ Colombia } & P04 & 49 & Femenino & 2 & Maestría \\
\hline & $\mathrm{P} 05$ & 47 & Masculino & 3 & Maestría \\
\hline & $\mathrm{P} 06$ & 40 & Femenino & 2 & Maestría \\
\hline
\end{tabular}

Fuente: Elaboración propia.

El grupo de directivos académicos entrevistados estuvo conformado por una mujer y tres hombres con edades entre los 40 y los 68 años y nivel de formación de maestría o doctorado; todos ocupan una posición en la cual tienen a su cargo la dirección de los profesores, tanto los de tiempo completo como los de tiempo parcial u hora cátedra. 
Tabla 2. Caracterización del grupo de directivos académicos

\begin{tabular}{|c|c|c|c|c|c|c|}
\hline País & Sujeto & Edad & Género & $\begin{array}{c}\text { Nivel académico } \\
\text { alcanzado }\end{array}$ & Cargo que ocupa & Antigüedad en el cargo \\
\hline \multirow{2}{*}{$\begin{array}{l}\text { Puerto } \\
\text { Rico }\end{array}$} & D01 & 40 & Masculino & Doctorado & $\begin{array}{l}\text { Director de } \\
\text { departamento }\end{array}$ & 1 año \\
\hline & D02 & 55 & Masculino & Doctorado & $\begin{array}{c}\text { Director de } \\
\text { departamento }\end{array}$ & 1.5 años \\
\hline \multirow[b]{2}{*}{ Colombia } & D03 & 68 & Masculino & Maestría & Decano de facultad & 25 años \\
\hline & D04 & 56 & Femenino & Maestría & $\begin{array}{l}\text { Directora de } \\
\text { programa }\end{array}$ & 1 año \\
\hline
\end{tabular}

Fuente: Elaboración propia.

\section{Técnicas e instrumentos}

Para la recolección de información se construyó un protocolo a fin de recabar datos sociodemográficos de los participantes y una entrevista semiestructurada, la cual implica "una guía de asuntos o preguntas y el entrevistador tiene la libertad de introducir preguntas adicionales para precisar conceptos u obtener mayor información" (Hernández, Fernández \& Baptista, 2014, p. 403).

En el marco de esta técnica, se construyeron dos instrumentos, uno para los profesores y otro para los directivos académicos, con un conjunto de preguntas referidas a tópicos sobre el contrato psicológico, tales como compromisos implícitos entre las partes en la relación de trabajo, expectativas y promesas. Las preguntas fueron del tipo, ¿qué compromisos adicionales cree que tiene con las universidades con las que trabaja, más allá de lo acordado en su contrato de trabajo?, para los profesores, y ¿qué compromisos adicionales cree que tienen los profesores hora cátedra con esta institución, más allá de lo acordado en su contrato de trabajo?, para los directivos académicos. La entrevista para profesores tuvo trece preguntas y para los directivos ocho. Los instrumentos fueron evaluados por un par de expertos y sometidos a una prueba piloto, a partir de lo cual se hicieron los ajustes correspondientes.

\section{Procedimiento}

Los sujetos fueron contactados personalmente por los investigadores y, una vez que aceptaron participar, se acordó el momento de la entrevista, la cual se grabó y transcribió para luego ser procesada por medio del programa ATLAS.ti 7. El análisis de la información se realizó mediante la técnica de análisis de contenido, según la perspectiva de Bardin (2002). La unidad de registro fue el tema y la regla de enumeración la presencia/ausencia, a partir de lo cual se identificaron categorías emergentes que 
daban cuenta de la configuración y características del contrato psicológico en los sujetos participantes del estudio.

\section{Consideraciones éticas}

El estudio contó con la elaboración de un protocolo de consentimiento informado que firmaron los participantes, y cuyo contenido, al igual que los instrumentos, fueron avalados por el Comité Institucional para la Protección de los Seres Humanos en la Investigación (CIPSHI) de la Universidad de Puerto Rico, Recinto de Río Piedras, con el número de protocolo 1415-222.

\section{Resultados}

Se presenta la información obtenida de las entrevistas, la cual se expresa en términos de categorías relacionadas con el contrato psicológico desde la perspectiva de cada uno de los grupos: en el caso de los profesores, lo que ellos creen que son sus compromisos hacia las universidades con las que trabajan y de estas hacia ellos, y en el caso de los directivos académicos, lo que ellos creen que son los compromisos de las universidades hacia los profesores y de estos hacia ellas.

\section{Configuración del contrato psicológico}

Los resultados que muestran la configuración del contrato psicológico en la relación de multiempleo se presentan en términos de categorías que emergieron del discurso en las entrevistas y que refieren aspectos clave de la manera como los entrevistados conciben su relación de trabajo desde la perspectiva del contrato psicológico.

Como se observa en la tabla 3 , en la perspectiva de los profesores se identificaron cinco categorías constitutivas del contrato psicológico, mientras que en la perspectiva de los directivos académicos fueron cuatro categorías, de las cuales tres están presentes también en la perspectiva de los profesores.

Tabla 3. Configuración del contrato psicológico

\begin{tabular}{cc}
\hline Perspectiva de los profesores & Perspectiva de los directivos académicos \\
\hline Actividades extra & Actividades extra \\
Estabilidad laboral & Estabilidad laboral \\
Reciprocidad & Reciprocidad \\
Realimentación & Compromiso \\
Reconocimiento & \\
\hline
\end{tabular}

Fuente: Elaboración propia. 


\section{Actividades extra}

Si bien el contrato psicológico se conceptualiza como un aspecto subjetivo de las personas en su relación de trabajo, y aunque implica aquellos compromisos que se suponen más allá de los acuerdos formales que constituyen el contrato jurídico, esto no significa que tales implícitos no correspondan con hechos o condiciones del cotidiano que experimentan las personas en su trabajo.

En este orden de ideas, el primer aspecto que aparece en el discurso de las personas en relación con el contrato psicológico es el conjunto de actividades extra que, suponen, son sus responsabilidades por el hecho de ser docentes de alguna universidad, aunque esto demande tiempo adicional que generalmente no tiene remuneración. Por ejemplo, dice uno de los profesores entrevistados:

Yo creo que mucho del tiempo que yo estoy aquí en mi casa lo estoy dedicando a calificar trabajos, a programar exámenes, a calificar proyectos, a hacer las clases, ahora por ejemplo estoy apoyando el proceso de autoevaluación en una de las universidades, eso me demanda una cantidad de trabajo enorme, entonces la verdad no he hecho el cálculo, pero es mucho, muchísimo el tiempo que yo estoy invirtiendo. (P04)

Y otro de los profesores afirma:

Uno establece unos horarios, unos acuerdos, pero realmente uno termina accediendo a otro tipo de tiempos, para poder brindarles el apoyo que ellos requieren... reuniones que sean por fuera del marco como del horario laboral establecido. Compromisos, por ejemplo, en esta semana tenemos un evento, entonces eso implica destinar unos tiempos y unos recursos adicionales para poder hacer una buena participación en el evento y eso no se incluye dentro del contrato. Revisión de los programas analíticos, evaluaciones. Entonces los compromisos son variados y toman bastante tiempo. (P06)

Otros dos profesores expresaron que la administración intermedia de una de las universidades en las que trabajan ha insinuado que tiene la expectativa de que los profesores por contrato parcial participen de las reuniones de facultad y de actividades comunitarias organizadas por sus colegas. Un participante dijo:

En [la universidad B] sí tienen la expectativa de que, si puedo, vaya [a las reuniones del departamento]. Hay veces que no voy a reuniones en [la universidad B] [...] porque tomo ese tiempo para preparar clases. En [la universidad B] no me lo dicen directamente, pero hay comentarios de que tienen expectativa de que te involucres lo más posible, y es algo difícil. Es ese contrato psicológico, porque cuando termine el doctorado el lugar que me pone adelante es [la universidad B] y eso me pone a mí en gran tensión. Si no voy a todas las actividades es porque estoy lidiando con mi trabajo 
aquí en [la universidad A]. No tengo carga completa en [la universidad B], pero es una presión inmensa. (P02)

Los compromisos del profesor son enseñar en su área de estudio, desarrollar un plan instruccional, preparar los planes y materiales del curso, evaluar el progreso de los estudiantes, cumplir con las horas de oficina y asistir a las reuniones de facultad. Esa es la prioridad para ellos, pues contractualmente ese es el acuerdo entre los empleadores y ellos. Sin embargo, como dice un profesor "lo mío no se limita al salón de clases" (P02). Presentarse a sí mismos como académicos implica realizar otras actividades y tareas no vinculadas a la enseñanza, así como integrarse plenamente en las actividades y tareas de la comunidad de académicos. Una profesora dijo: "Pienso que es importante, la integración, porque ciertamente, pues es una facultad, es un departamento, son colegas, somos colegas" (P01). Los profesores se han integrado a comités académicos y administrativos, están activamente coordinando actividades académicas para el departamento y, en el caso de una profesora, está haciendo recomendaciones para crear una subespecialidad en su área de especialidad de estudio.

\section{Estabilidad laboral}

Un segundo aspecto que aparece tanto como una expectativa como un temor es el relacionado con la estabilidad laboral.

Como expectativa, los profesores esperan que las universidades les renueven el contrato en el periodo siguiente o que se les aumente el número de horas de docencia para así aumentar sus ingresos, tal como se evidencia en la siguiente pieza discursiva:

Yo siempre he esperado de estas organizaciones es que, si mis valoraciones y evaluaciones son positivas, ¿sí? yo esperaría por un lado una permanencia, la posibilidad de tener siempre una carga académica mayor o en lo posible igual [...] Yo esperaría estabilidad y la posibilidad en algún momento de un aumento en las horas. (P05)

Sin embargo, un hecho importante que aparece en los discursos de los entrevistados es que conciben que, para la renovación del contrato o la permanencia en las universidades, deben llevar a cabo acciones de visibilización o "actividades extra" como forma de demostrar compromiso con las instituciones. Uno de los profesores afirma:

También esperan [los directivos] que uno todo el tiempo se esté cualificando, se esté metiendo en semilleros, se esté metiendo en cosas de investigación, se esté metiendo en autoevaluación, se esté metiendo en una cantidad de cosas, para que uno así, entonces pueda ser como mejor ranqueado, ¿isí? Creo que también eso es lo que esperan. (P04) 
En este sentido, los profesores participantes sienten que tienen que estar demostrando que son merecedores de una renovación del contrato:

\begin{abstract}
Tienen que demostrar, ¿eh? Uno está aquí todo el tiempo demostrando que maneja el tema. Entonces, eso te genera, además del estrés y toda la cosa, pero te coge más tiempo. Así que esa jornada tuya se sigue, se hace más intensa, pero es también porque uno también tiene que estar demostrando. (P01)

Yo estoy haciendo mucho más que profesores a tiempo completo. [...] Hay percepción de los departamentos de que esta persona es bien productiva. No te dan más cosas en términos laborales por términos de arriba. Pero sí mi desempeño ha influido y ha dado una percepción en [la universidad B] de que queremos esta persona aquí. (P02) Para volver a ser contratados necesitamos cumplir con los estándares de la universidad: investigación, publicación y aportar con el conocimiento. Lo dijo claramente [un administrador], yo lo escuché. Para volver a ser contratado, pues lo dijeron en esa reunión. Hacer presentaciones y publicar. Tenemos que estar en el spot. (P03)
\end{abstract}

Estas aspiraciones y expectativas los han llevado a cumplir con las "recomendaciones", que no son otra cosa que "los requisitos para estar aquí". Hacer esas actividades no remuneradas económicamente les hace sentir que aumentan la posibilidad de mejorar su empleo con estabilidad y un mejor salario.

\title{
Reciprocidad
}

El tema de la reciprocidad es un asunto clave en la teorización sobre contrato psicológico, ya que la sola concepción de contrato supone una condición recíproca entre las partes. Sin embargo, aunque se espera un trato equitativo, la percepción de los profesores es que esta condición es desequilibrada con perjuicio para ellos. Por ejemplo, dice uno de los entrevistados: "no compensa el tiempo que nosotros dedicamos para toda la preparación de lo que implican las clases frente a lo que nos ganamos" (P04). No importa cuánto hagan, el empleador les ofrece un contrato temporal. Según estimaciones de algunos de los profesores, ellos pueden llegar a trabajar entre 50 a 60 horas semanales, cuando el contrato legal establece que su jornada de trabajo corresponde a las horas contacto en el salón de clase. Así, por ejemplo, a un profesor que tiene cinco cursos ( 15 créditos) en dos universidades, le están pagando 15 horas semanales, trabajando ad honorem aproximadamente entre 35 a 45 horas a la semana. Hay una desproporción entre las obligaciones de los profesores y los beneficios que reciben del empleador. Trabajan como si fueran profesores de tiempo completo, pero les pagan de acuerdo a sus contratos a tiempo parcial. 
Una de las razones para que la reciprocidad desigual ocurra es que la administración intermedia de algunas universidades da por sentado que los profesores por contrato tienen que hacer actividades y tareas extracontractuales debido a que son parte de la facultad. Una segunda razón es que la administración intermedia tiene necesidad de personal docente que trabaje en los comités departamentales. Esto les lleva a tener que pedirles a los profesores por contrato que participen de los comités y, de esa manera, poder cumplir con los planes de trabajo del departamento. Una tercera razón, vinculada directamente con la segunda, es que hay profesores de plaza regular (tiempo completo) que se niegan a participar de los comités. Este problema de supervisión y control dentro de la organización resulta en una mayor carga de trabajo para los profesores por contrato.

\title{
Retroalimentación
}

La realimentación al desempeño aparece en la configuración del contrato psicológico en la perspectiva de los profesores, tanto como una necesidad como una concepción de ellos sobre el compromiso que deben tener los directivos académicos y las universidades en general. Dice uno de los profesores: "yo sí considero importante que al profesor se le diga, después de que pasa la evaluación, 'usted lo hace muy bien, y la calificación que le dieron los estudiantes fue esta', y lo hace público” (P04).

Otro de los entrevistados afirma:

\begin{abstract}
¿Qué espero de mis jefes? Bueno, por un lado me parece importante que haya retroalimentación, a veces, no me ha pasado directamente hasta ahora, pero a veces eso se necesita un poco y es que no se retroalimente solo cuando hay evaluaciones negativas. Muchas veces uno ve que se toman decisiones que ni siquiera en su momento se le comentaron directamente al afectado, ¿sí? Como ver un panorama de opciones, entonces, digamos que yo esperaría que lo retroalimenten a uno en ambas condiciones, tanto en lo positivo como en lo negativo, pero me he encontrado casos en los que de un momento a otro las personas no están, y simplemente se tomaron decisiones que en algún momento dado me parece que lo más correcto es que le muestre a uno el panorama, los posibles cambios negativos como positivos. (P04)
\end{abstract}

A pesar de que los participantes son productivos en las áreas de docencia, investigación y otros servicios, expresaron desconocer si están objetivamente cumpliendo con las expectativas de la universidad: "la universidad no provee nada. Así que tú no sabes cuáles son las expectativas" (P01); "uno va así como a ciegas, porque no sabe" (P03); "si interrumpo las horas de martes y jueves [de la universidad A] para acudir 
a reuniones o eventos oficiales de [la universidad B], pero, cuando regreso a mi casa, ¿qué tal si me dan una patada? ¿Qué todo esto no valió la pena?” (P02).

No poder descifrar apropiadamente las expectativas de la universidad ni poder predecir su futuro laboral los coloca en una posición de riesgo. Sin embargo, participar de actividades de investigación y colaborar en los comités de los departamentos les hace sentir que aumentan la posibilidad de mantener el empleo.

\section{Reconocimiento}

Un aspecto asociado a la realimentación es el reconocimiento que esperan algunos de los profesores por la realización de sus labores:

Yo esperaría como ser un lugar un poco más visible frente a las cosas que nosotros estamos haciendo bien como docentes [...] yo esperaría un reconocimiento, un reconocimiento un poco más importante a lo que uno hace, porque a veces la labor del docente hora cátedra en las instituciones es poco valorada. (P04)

Y otro de los entrevistados afirma:

Pues realmente a veces uno espera un reconocimiento de la labor que se logra, pues ya que no es solamente la condición de estar allí, y el conocimiento y la experiencia que uno haya podido adquirir, sino que se valore ese trabajo adicional que se hace en compromiso con los procesos de formación. Que se pueda valorar esos recursos adicionales que uno aporta en los diferentes escenarios para poder sacar adelante los resultados. (P06)

El reconocimiento implica también la visibilización de los profesores catedráticos o de tiempo parcial como miembros de las instituciones, hacerlos sentir que son también parte de las mimas, como lo refiere uno de los entrevistados: "llevo trece años en la universidad privada, y yo sigo sintiéndome como si fuera en medio de todo para la institución como un extraño que simplemente va a ir a un tiempo de clases y vuelve y sale" (P04).

Perspectiva del grupo de directivos académicos

\section{Actividades extra}

En general, aunque los directivos académicos no hacen exigencias directas sobre la realización de actividades extra, sí manifestaron en las entrevistas que esperan que 
los profesores participen de algunas de las actividades de la facultad, más allá del compromiso de la ejecución de las clases, particularmente el asunto relacionado con la asistencia a reuniones que se programen, como lo afirma uno de los directivos: "pienso que es su responsabilidad cumplir con otras solicitudes que el mismo programa le[s] demanda, por ejemplo, asistencia a las reuniones" (D04).

Este asunto de la participación de los profesores en actividades más allá del ejercicio de la docencia está relacionado también, en la perspectiva de los directores, con la imagen que proyecta el profesor para sus futuras contrataciones. Uno de los directores expresó que está consciente del impacto que pueden tener los compromisos adicionales en la recontratación del profesor por contrato, específicamente en la manera en que el comité de personal percibe a los profesores por contrato.

Eso no significa que los profesores por contrato a tiempo parcial como completo, quieran hacer, ¿verdad?, tomen iniciativas que vayan más allá de lo que se les requiera con la posible idea de que genuinamente lo quieran hacer, pero que también entiendan que tiene un impacto positivo sobre cómo los percibe el comité de personal, que son quienes los van a recomendar o no, etcétera. (D01)

Estabilidad laboral

Además de la incertidumbre que viven los profesores, dos de los directores expresaron que existe una incertidumbre laboral estructural. Esto quiere decir que, aunque los profesores por contrato sean evaluados positivamente y sean recomendados por el comité de personal, ellos no tienen certeza de que podrán recontratarlos.

Mira, a veces yo digo, yo me siento mal, pero a veces le tengo que decir al profesor: Mira, profesor, esto está sujeto a cambio. (D02)

Cuando se acaba el contrato, ni el profesor sabe si eso se va a renovar, ni yo como director lo sé. No, inclusive, porque no [se trata de que]el comité de personal no lo quiera recomendar o quiera volver a recomendar a otra persona, por el mero hecho de que yo no sé si van a volver a aprobar los fondos para ese contrato. (D01)

\section{Reciprocidad}

Algunos de los directivos académicos entrevistados son conscientes de la inequitativa reciprocidad que existe en la relación de trabajo con los profesores hora cátedra o de tiempo parcial. Dice uno de los participantes: "no debería haber ningún tipo de diferencia entre los derechos que tiene el docente de cátedra con respecto a un docente que permanece mayor tiempo en una institución" (D04). 
En este sentido, para los directivos son claras las diferencias que tienen, en cuanto a beneficios, los profesores hora cátedra en relación con los que trabajan tiempo completo:

¿Quién participa en los congresos? ¿Quién va a determinadas actividades? pues generalmente son los profesores de tiempo completo. Los de cátedra muy pocas oportunidades tienen, porque además su tarea ha sido más dirigida precisamente es al cumplimiento de asignaturas, de desarrollo de actividades muy puntuales. (D04)

\section{Compromiso}

Uno de los aspectos que constituyen supuestos de responsabilidad adicionales por parte de los profesores, según lo expresan algunos directivos, es el de un alto nivel de compromiso que deben manifestar los primeros hacia la universidad. Dice uno de los entrevistados: "yo no entendería una persona o un maestro aislado, sin tomar en cuenta los propósitos, las metas, los indicadores que estemos buscando en la institución" (D03). Otro de los directivos manifiesta que lo que más espera de los profesores es "que amen lo que hacen [...] por eso centro más la expectativa del cumplimiento en términos de lo que es la responsabilidad y el amor por lo que hace y su compromiso de hacer las cosas bien" (D04).

\section{Discusión}

Los resultados obtenidos en el presente estudio permiten evidenciar dos asuntos fundamentales: uno referido a la condición de multiempleo y el otro al tipo de vinculación laboral como profesores catedráticos o de tiempo parcial.

En cuanto a la condición de multiempleo, para algunos profesores esta condición es adecuada y manifiestan no desear cambiar por una contratación de tiempo completo, como lo refieren dos profesores:

A mí no me interesaría estar dentro de las universidades. Prefiero, así tenga una cantidad de trabajo enorme, dentro de las universidades creo que sería, o sea, no, no, o sea no es lo que yo deseo en este momento de mi vida... no deseo estar dentro de ellas. (P04)

La verdad siempre he trabajado en esta modalidad y nunca he esperado una vinculación directa. He tenido la oportunidad de tenerla, pero nunca la he aceptado. Yo esperaría estabilidad y la posibilidad en algún momento de un aumento en las horas. (P05) 
Sin embargo, en otros casos sí existe la expectativa de poder vincularse con dedicación completa a alguna de las universidades, como es el caso de dos profesores que expresaron tener aspiraciones y expectativas de ser docentes con plaza regular o tiempo completo. Las expectativas surgen debido a que la administración intermedia de una de las universidades donde trabajan les ha hecho recomendaciones para que se conviertan en buenos candidatos para esta posición. Uno de los profesores manifestó: "si me han prometido plaza, la respuesta es que no. Pero, ¿comentarios e indirectas [de la administración intermedia]? Tengo que admitirte que sí” (P02).

De otra parte, no se encontraron diferencias importantes respecto a las características de los contratos psicológicos que cada profesor podría establecer de manera diferenciada respecto de cada universidad con la que trabaja. La vinculación laboral con cada institución genera vínculos similares del profesor con las distintas universidades, por ejemplo, "a las dos [universidades] les debo también como un sentido de mucha responsabilidad y mucho respeto, yo, la verdad, tengo una identificación clara con las dos instituciones" (P04), dado que el eje en torno al cual se configura el contrato psicológico es la función docente más que la relación contractual con cada institución. Al respecto, un profesor manifiesta:

\footnotetext{
Quiero seguir haciendo esto por el resto de mi vida. También si me voy a involucrar en algo, quiero hacerlo bien. Uno asume una responsabilidad grande cuando se inserta en la academia. No es meramente ir al salón de clases, decir dos o tres cosas y ya, dame el cheque. También hay que aportar en la producción de conocimiento. (P02)
}

En este caso, una construcción de identidad profesional e identificación con su trabajo permiten un alto compromiso con su labor, más allá de las condiciones contractuales, lo cual lleva a los profesores incluso a laborar horas adicionales en la ejecución de actividades complementarias a la función docente.

En cuanto al tipo de vinculación laboral y su relación con la configuración del contrato psicológico, se evidencia una reciprocidad desbalanceada, puesto que los profesores perciben que no reciben a cambio una compensación equitativa acorde con los tiempos que dedican a cada universidad. Inclusive, se observa que buena parte de esta dedicación extra ocurre como estrategia de visibilización ante los directivos de las universidades, como forma de lograr continuidad en los contratos y de esta manera asegurar una relativa estabilidad laboral. Este hecho pone en evidencia las diferencias entre el denominado trabajo prescrito y el trabajo real (Pujol, 2011), lo cual implica tensiones entre las actividades que se supone deben hacerse y lo que realmente se hace; por ejemplo, cuando se generan condiciones de estrés porque el trabajo real supera en gran medida el trabajo prescrito, tales condiciones se aceptan 
por el temor de que el contrato no sea renovado. En este hecho existe "la sensación de que 'cuidar' el empleo supone aceptar $-\mathrm{y}$ en muchos casos naturalizar- exigencias y condiciones insatisfactorias" (Pujol, 2011, p. 221).

En algunos casos, los directores académicos solicitan a los profesores por contrato que sometan su currículum actualizado para que el comité de personal evalúe si recomienda o no la renovación del contrato. Esta acción refuerza la percepción que tienen los profesores participantes de que aquellos que hagan actividades y tareas adicionales a la enseñanza tendrán una mejor oportunidad de continuar empleados.

La necesidad de retroalimentación al desempeño es otro aspecto clave que caracteriza la configuración del contrato psicológico en la perspectiva de los profesores. Aunque es un asunto importante para ellos, esto no siempre se hace por parte de los directivos académicos, según se desprende de las entrevistas hechas, generando incertidumbre por la falta en los profesores sobre su posible continuidad en los contratos. La retroalimentación, igualmente, se encuentra asociada a la expectativa de tener un adecuado reconocimiento por las labores realizadas.

Varios autores (Alcover, 2002; Conway \& Briner, 2005, 2009; Guest, 2004; Taylor \& Tekleab, 2004; Topa, 2005) coinciden en destacar la importancia que tiene el concepto "contrato psicológico" para el análisis y comprensión de la forma como se construyen actualmente las relaciones de trabajo, y puesto que el multiempleo es una de las formas en que actualmente se realizan las vinculaciones de personas al mundo del trabajo, el estudio del contrato psicológico en este ámbito permite la comprensión de la manera como las prácticas de gestión de personal en las organizaciones impactan la subjetividad de los trabajadores.

El presente estudio ha permitido comprender cómo la vinculación multiempleo en profesores universitarios no genera diferencias en la manera como se configuran los contratos psicológicos con distintas organizaciones, pues más allá de la relación con las mismas, lo que actúa como elemento articulador en las relaciones laborales es el vínculo con el trabajo y la construcción de una identificación con este. De esta manera, el contrato psicológico se concibe en este caso como compromisos implícitos con la profesión o la actividad docente, más que con las organizaciones con las cuales se tiene un contrato jurídico laboral.

Igualmente, este estudio ha permitido evidenciar las tensiones psicológicas que enfrentan los profesores catedráticos o de tiempo parcial, dada la sobrecarga de trabajo que se genera en el desempeño de sus funciones y la incertidumbre que tienen por la falta de retroalimentación en el desempeño, así como la expectativa incierta sobre su continuidad laboral en los siguientes periodos de trabajo. Sin embargo, la realización 
de actividades extra, concebidas como parte de su contrato psicológico, se convierte en una estrategia de empleabilidad y de aseguramiento de su continuidad laboral.

Los hallazgos aquí presentados son válidos para el ámbito en el que se realizó el estudio, esto es, la educación superior; en tal sentido, es muy probable que en otros ámbitos sí se presenten diferencias en los contratos psicológicos en condición de multiempleo, aspecto que debería ser abordado en futuros estudios. Igualmente, una investigación desde una perspectiva cuantitativa con una amplia muestra estadísticamente representativa permitiría aportar otro tipo de evidencias para el estudio del contrato psicológico en condiciones de multiempleo.

\section{Referencias}

Agarwal, P. (2014). The psychological contract: a review model. IIMA Working Papers. Indian Institute of Management Ahmedabad, Research and Publication Department.

Alcover, C. M. (2002). El contrato psicológico: el componente implícito de las relaciones laborales. Aljibe.

Argyris, C. (1960). Understanding organizational behavior. Dorsey.

Bardin, L. (2002). El análisis de contenido. Akal.

Consejo de Educación de Puerto Rico. (2016). Compendio estadístico sobre la educación superior de Puerto Rico. Año académico 2015-2016. https://estadisticas.pr/files/Inventario/ publicaciones/Databook_CEPR_Superior_\%282015-16\%29octubre2016_1.xlsx

Conway, N. \& Briner, R. (2005). Understanding psychological contracts at work: a critical evaluation of theory and research. Oxford.

Conway, N. \& Briner, R. (2009). Fifty years of psychological contract research: what do we know and what are the main challenges? International Review of Industrial and Organizational Psychology, 24, 71-130.

Coyle-Shapiro, J. \& Parzefall, M. (2010). Psychological contracts. En: C. Cooper \& J. Barling (eds.). The sage handbook of organizational behavior (pp. 17-34). Sage Publications. http://eprints.lse.ac.uk/26866/

Crowe, S., Cresswell, K., Robertson, A., Huby, G., Avery, A. \& Sheikh, A. (2011). The case study approach. Medical Research Methodology, 1-9. doi:10.1186/1471-2288-11-100

De Bruyne, P., Herman, J. \& De Schoutheete, M. (1991). Dinâmica da pesquisa em Ciêcias sociais. Francisco Alves Editora.

García-Prado, A. \& González, P. (2006). El pluriempleo entre los profesionales sanitarios: un análisis de sus causas e implicaciones. Gaceta Sanitaria, 20(2), 29-40.

García-Rubiano, M. \& Forero-Aponte, C. (2015). Contrato psicológico y cambio organizacional en una entidad perteneciente al sector terciario de la ciudad de Bogotá, Colombia. Revista de Investigación Desarrollo e Innovación, 6(1), 15-28. 
George, E. (2003). External Solutions and Internal Problems: The Effects of Employment Externalization on Internal Workers' Attitudes. Organization Science, 14(4), 386 -402.

González, F. L. (2007). Investigación cualitativa y subjetividad: los procesos de construcción de la información. McGraw-Hill.

Grimshaw, D., Marchington, M., Rubbery, J. \& Willmott, H. (2005). Fragmenting work across organizational boundaries. En M. Marchington, D. Grimshaw, J. Rubbery \& H. Willmott (edits.). Fragmenting work: Blurring organizational boundaries and disordering hierarchies (pp. 1-38). Oxford University.

Guest, D. (2004). The Psychology of the Employment Relationship: An analysis based on the Psychological Contract. Applied Psychology, 53(4), 541-555.

Hernández, R., Fernández, C. \& Baptista, M. d. (2014). Metodología de la investigación (6a ed.). McGraw-Hill.

Levinson, H., Price, C., Munden, K., Mandl, H. \& Solley, C. (1962). Men, Management, and Mental Health. Harvard.

Ministerio de Educación Superior. (2016). Sistema Nacional de Información de la Educación Superior. https://snies.mineducacion.gov.co/portal/ESTADISTICAS/Bases-consolidadas/

Pujol, A. (2011). La tensión entre lo prescrito y real y su impacto en la calidad del trabajo subjetivamente percibida: Un análisis clínico. En J. C. Zanelli, N. Silva \& S. da Rosa (eds.). Processos psicossociais nas organizações e no trabalho (pp. 219-233). Casapsi.

Rousseau, D. (1995). Psychological contracts in organizations: understanding written and unwritten agreements. Sage.

Rubery, J., Earnshaw, J. \& Marchington, M. (2005). Blurring the boundaries to the employment relationship: from single to multi-employer relationships. En: M. Marchington, D. Grimshaw, J. Rubery \& H. Willmott (eds.). Fragmenting work (pp. 63-87). Oxford.

Silla, I., Gracia, F.-J. \& Peiró, J.-M. (2005). Diferencias en el contenido del contrato psicológico en función del tipo de contrato y de la gestión empresarial pública o privada. Revista de Psicología Social, 20(1), 61-72.

Taylor, M. S. \& Tekleab, A. G. (2004). Taking stock of psychological contract research: assessing progress, addressing troublesome issues, and setting research priorities. En :J. A.-M. Coyle-Shapiro, L. M. Shore, M. S. Taylor \& L. E. Tetrick (eds.). The employment relationship. examining psychological and contextual perspectives (pp. 253-283). Oxford.

Topa, G. (2005). El contrato psicológico: un nuevo marco para comprender las relaciones dentro de las organizaciones. En F. J. Palací (ed.). Psicología de la organización (pp. 101119). Pearson.

Vesga, J. J. (2011). Los tipos de contratación laboral y sus implicaciones en el contrato psicológico. Pensamiento Psicológico, 9(16), 171-182. 



\section{8 \\ CARACTERIZACIÓN DEL \\ CONTENIDO DEL CONTRATO \\ PSICOLÓGICO EN UN GRUPO \\ DE VOLUNTARIOS DE UNA \\ ORGANIZACIÓN SIN ÁNIMO DE \\ LUCRO EN COLOMBIA}

Estefanía Aponte-Restrepo*

Álvaro Giovanni González-Herrera**

Fundación Universitaria Konrad Lorenz

\section{Introducción}

Las nuevas realidades laborales están caracterizadas por modelos flexibles de nexos laborales a través de los cuales las personas que pertenecen a una organización no se encuentran vinculadas necesariamente por contratos de trabajos formales, sino por un tipo de relacionamiento informal, lo que constituye una modalidad de trabajo en el mundo (Vélez, 2017). Existen variadas modalidades de trabajo, entendidas como "las diferentes formas como las personas se vinculan a las organizaciones en calidad de trabajadores" (Vesga, 2007, p. 82), que aún no han sido exploradas desde la mirada de los factores que pueden incidir en la relación laboral que se establece entre el individuo y la organización que lo recibe; es aquí cuando cobra sentido el concepto de contrato psicológico. Este concepto se origina en las ciencias sociales en los últimos años de la década de los cincuenta y principios de los sesenta, con el fin de hacer hincapié en las expectativas y creencias existentes entre el empleador y el trabajador, en una relación laboral, que no hacen parte del contrato formal. A finales de la década de los noventa, Rousseau, plantea una reconceptualización haciendo énfasis en lo dinámico que este tipo de contrato podría llegar a ser por las necesidades cambiantes

* https://orcid.org/0000-0002-7883-1846

${ }^{* *}$ https://orcid.org/0000-0001-6457-2014 
del contexto laboral, tanto emocionales como sociales, y no solo por motivos económicos, como se interpretó en su momento (Alcover, 2002). Al mismo tiempo, conceptualiza que un contrato es un modelo mental usado por el ser humano para demarcar situaciones de promesas realizadas, condiciones para la ejecución de estas y para lograr un nivel de confianza óptimo en el campo en que se desarrolle.

Esta precisión trae consigo una visión más amplia y compleja del contrato psicológico, pues da la posibilidad de diferentes interpretaciones perceptuales de cada una de las partes involucradas (Tena, 2002). Dichas percepciones y conceptos se basan en un conjunto de acuerdos, promesas y compromisos, tanto implícitos como explícitos, que ambas partes intercambian en las primeras etapas de su relación, lo que hace que el contrato psicológico sea un modelo psicológico flexible que se va desarrollando y ajustando progresivamente, indicando así las expectativas que se tienen frente a este y las contribuciones que traerá dicha relación bidireccional (Cantisano, Fernández \& Lisbona, 2005). Esto definirá el contenido del contrato psicológico. Se debe tener presente que las percepciones no solo hacen referencia a un fenómeno psicológico, ya que involucran a su vez procesos psicosociales, al influenciar en interacciones e influencias sociales del contexto específico (Alcover, 2002), como son la duración y permanencia en la organización.

Es importante tener claro que el contenido del contrato psicológico se genera a partir de las percepciones mencionadas anteriormente, así como de los valores, normas, motivaciones, relaciones interpersonales y expectativas de ambas partes; es decir, tiene en cuenta variables tanto del individuo como del contexto social y de las experiencias propias del trabajo (Dabos \& Rousseau, 2004).

Algunas investigaciones realizadas en diferentes modalidades de trabajo muestran que las actitudes relacionadas con el contrato psicológico no varían significativamente entre voluntarios y empleados con remuneración económica, pues las expectativas, la disciplina, y las evaluaciones generan contratos psicológicos similares. Sin embargo, se encontró que hay una mejor ejecución y mayor compromiso de los voluntarios relacionado a los beneficios que tienen en cuanto a libertad y menor tensión legal respecto a su rol (Liao-Troth, 2001).

En contraposición a esto, Harman y Doherty (2014) aseguran que en estudios anteriores del contrato psicológico en voluntarios se han logrado identificar categorías que no se relacionan a un entorno de trabajo remunerado, como la autonomía, credibilidad y relaciones sociales, las expectativas particularmente sobresalientes que los voluntarios tienen de su organización y contribución a la misión de la organización, la dedicación evidenciada en horas extras y la iniciativa que muestran al buscar nuevas alternativas para ejecutar sus responsabilidades e innovar. Esto reafirma que el contenido del 
contrato psicológico varía en cada población y se vuelve específico a una modalidad de trabajo, y muestra la importancia de profundizar en el estudio con esta población.

\section{Voluntariado}

Modalidades de trabajo tales como el voluntariado son variadas, están ancladas a la informalidad laboral y tienen diferentes objetivos y motivaciones que van más allá del interés simplemente económico. Para Ascoli (citado por Gómez y Olave \& Mielgo Martínez, 1989), el voluntariado puede definirse como el quehacer de personas que ofrecen un tiempo de trabajo gratuito y se comprometen establemente en la prestación de servicios sociales. Esta actividad se desempeña principalmente en entidades sin ánimo de lucro, pertenecientes al tercer sector en Colombia, que realizan actividades en pro de otras personas o poblaciones específicas y tienen gran incidencia en el contexto social y económico del país, pues generan mayor conciencia sobre el medio ambiente, la niñez, la juventud, los discapacitados, entre otros (Ramos, 2012).

Los voluntarios proporcionan una fuerza de trabajo no remunerado pero relevante en muchos países del mundo, y contribuyen de forma significativa a sectores tan diversos como la salud, el bienestar, las artes y el medio ambiente, volviéndose vitales en el sistema económico de las diferentes organizaciones a las que se encuentran vinculados. Por esto, sostener el número de voluntarios para estos servicios es claramente importante pero a su vez difícil (Stirling, Kilpatrick \& Orpin, 2011). Esta dificultad se podría disminuir al identificar el contrato psicológico en esta población y al clarificar la percepción de los voluntarios respecto a la organización y a los beneficios que recibirán a cambio de trabajo no remunerado, basados en el capital social, que consiste en las redes sociales, la confianza, la reciprocidad y normas sociales.

De igual forma, las relaciones sociales, incentivos afectivos materializados en vínculos profundos y estables (amistad), son la principal motivación de los voluntarios, y los conciben como incentivos solidarios. Estas relaciones permiten identificar parte del contenido del contrato psicológico, pues los voluntarios tienen más preocupación por los beneficios sociales y personales (conocimientos y habilidades) que por los monetarios (Kim, Trail, Lim \& Kim, 2009).

Ante lo expuesto, el contrato psicológico se convierte en interés de los estudios de la psicología organizacional y del trabajo, por lo que la presente investigación se orientó a caracterizar el contenido del contrato psicológico en un grupo de voluntarios de una organización sin ánimo de lucro. La investigación amplía el conocimiento existente del constructo y permite una reflexión de la experiencia subjetiva de las personas en un contexto laboral. 


\section{Método}

Esta investigación es de tipo descriptivo y de orientación cualitativa, enfocada en la captación y reconstrucción de la subjetividad para comprender la realidad sociocultural de un modo flexible y desestructurado, realizando un procedimiento inductivo (Ruiz, 2012), analizado desde la teoría fundamentada (Strauss, Corbin \& Zimmerman, 2002). El estudio contó con la participación de 16 voluntarios, hombres y mujeres, entre los 18 y 85 años, vinculados a una organización sin ánimo de lucro de Colombia fundada en 1953 y dedicada a la promoción, formación, organización y servicio a la niñez y la juventud, brindando procesos de formación integral en el liderazgo; la organización está ubicada en la ciudad de Bogotá, y ninguno de los participantes recibe remuneración salarial por su quehacer.

Tabla 1. Descripción sociodemográfica de participantes

\begin{tabular}{|c|c|c|c|c|c|}
\hline Tipo de contrato & & Rol & & \multicolumn{2}{|c|}{ Género } \\
\hline Informal & Líderes & Staff & Vitalicios & $\mathrm{F}$ & M \\
\hline 16 & 9 & 6 & 1 & 7 & 9 \\
\hline Rango antigüedad & 3-10 años & 11- 50 años & 50- 60 años & \multicolumn{2}{|c|}{ Estrato promedio } \\
\hline Escolaridad promedio & Estudiantes pregrado & \multicolumn{2}{|c|}{ Profesionales pregrado } & \multirow{2}{*}{\multicolumn{2}{|c|}{ Medio alto }} \\
\hline Edad promedio & 23 años & 30 años & 86 años & & \\
\hline
\end{tabular}

Fuente: Elaboración propia.

Para la selección de la muestra, se realizó un muestreo no probabilístico por cuotas, de acuerdo con lo planteado por Barreto, Velandia y Rincón (2011). Este tipo de muestreo presupone un buen conocimiento de la forma como los individuos se encuentran naturalmente agrupados, asumiendo que hay características comunes claramente identificadas en la población objeto de estudio, con el fin de que los distintos segmentos estén representados proporcionalmente en la muestra. Los participantes de cada cuota no se seleccionaron de forma aleatoria sino de forma intencional debido a la disponibilidad y disposición de los participantes de la investigación (Creswell, 2008).

\section{Instrumentos y estrategias de recolección de información}

Para cada una de las cuotas de la muestra se plantea la ejecución de grupos focales, técnica de recolección de información enmarcada dentro de la investigación sociocualitativa, que facilita discutir, indagar e interpretar con varias personas, y de forma 
simultánea, sobre un tema de investigación determinado, priorizando la profundidad sobre la extensión de la información recolectada (Martínez, 2015).

\section{Categorías orientadoras y ejes de indagación}

Para la recolección de información, los grupos focales se realizaron con base en los aportes teóricos de categorías preestablecidas, relacionadas con el contenido del contrato psicológico, de las cuales se derivaron ejes de indagación o subcategorías que permitieron la formulación de las preguntas del instrumento (véase tabla 2).

Para el desarrollo de la investigación se procedió de la siguiente manera: se realizó el diseño y construcción de las estrategias de evaluación y validación con tres jueces

Tabla 2. Categorías orientadoras y ejes de indagación

\begin{tabular}{|c|c|c|}
\hline & Categorías orientadoras & Ejes de indagación \\
\hline Expectativas & $\begin{array}{l}\text { Motivaciones que están basadas en futuros rendimientos, o bien en la } \\
\text { propia experiencia pasada o el contexto específico en el que desarrollar } \\
\text { (Díez, 2015). Probabilidad percibida por la persona de que a cierto } \\
\text { comportamiento o acción corresponderá cierto resultado (Alcover, 2002). } \\
\text { Una expectativa implica una condición razonable que refleja cierto nivel } \\
\text { de certeza para el individuo de que un hecho determinado puede darse en } \\
\text { el futuro, usando sus aprendizajes previos relacionados con el asunto sobre } \\
\text { qué es la expectativa; en el contexto laboral, implica la relación establecida } \\
\text { entre las condiciones presentes de su quehacer y la probabilidad de que estas } \\
\text { cambien o se mantengan en el futuro (Vesga, 2014). }\end{array}$ & $\begin{array}{l}\text { Rendimientos } \\
\text { futuros }\end{array}$ \\
\hline Compromiso & $\begin{array}{l}\text { Representa las intenciones de las partes de mantener la relación en un } \\
\text { largo plazo, reduciendo la probabilidad a que las personas sean receptivos a } \\
\text { ofertas de vinculación a otras entidades (Díez, 2015). } \\
\text { El compromiso organizacional permite estabilidad laboral, que impacta en } \\
\text { beneficios sociales, garantizando satisfacer necesidades tanto materiales } \\
\text { como psicológicas (desarrollo de habilidades, socialización, estatus) y } \\
\text { beneficiando el ambiente en el que se desarrolle (Betanzos \& Paz, 2007). }\end{array}$ & $\begin{array}{c}\text { Permanencia } \\
\text { Estatus } \\
\text { Beneficios sociales } \\
\text { Desarrollo de } \\
\text { habilidades } \\
\text { Socialización }\end{array}$ \\
\hline Obligaciones & $\begin{array}{l}\text { Se puede explicar cómo la parte en la que el empleado asume responder a } \\
\text { solicitudes realizadas por parte del empleador (Varona, citado por Betanzos } \\
\text { \& Paz, 2006, p. 38), que implica un reconocimiento de lo que él ha aportado } \\
\text { (Betanzos \& Paz, 2006, p. 38). Grado en que el empleado ha adoptado una } \\
\text { serie de promesas con su organización (Cardozo, 2016). } \\
\text { Acción que realiza el individuo atendiendo a una necesidad de un contexto } \\
\text { determinado en función de unas condiciones personal o contextual y desde } \\
\text { su rol dentro de la organización. }\end{array}$ & $\begin{array}{c}\text { Promesas } \\
\text { Condición personal }\end{array}$ \\
\hline
\end{tabular}

Fuente: Elaboración propia. 
expertos, posteriormente se procedió a la sistematización de la información, análisis de los resultados y finalmente se elaboró la conceptualización de los constructos a trabajar.

\section{Resultados}

El análisis de la información obtenida se realizó a través de una metodología de análisis de contenido, a partir de las inferencias que se generan de los textos a analizar (Sánchez \& Berrocoso, 2017). Este análisis implica dos momentos: uno de organización, procesamiento y análisis de la información, y otro de abstracción e interpretación de esta (Gil \& Cano, 2010). El procesamiento de los datos se realiza con el apoyo del programa NVivo 11 para Windows, software que permitió, de una forma metódica y sistematizada, codificar, relacionar y graficar las categorías identificadas en el contenido del contrato psicológico de los voluntarios entrevistados (véase figura 1).

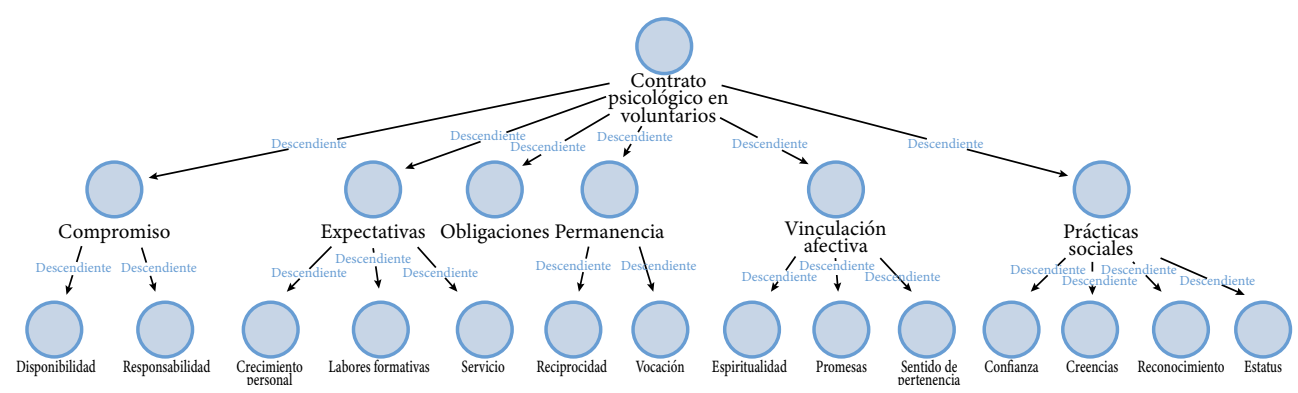

Figura 1. Diagrama de relaciones del contenido del contrato psicológico en voluntarios. Fuente: elaboración propia.

Los resultados del diagrama de relaciones del contenido del contrato psicológico de los voluntarios (figura 1), indican que este contenido está caracterizado por seis categorías principales: el compromiso, las expectativas, las obligaciones (categorías preestablecidas), la permanencia, la vinculación afectiva y las prácticas sociales, siendo estas tres últimas categorías emergentes que surgieron en el proceso de análisis.

Estas seis categorías se presentarán según son percibidas por los voluntarios de la siguiente manera: en primera instancia se menciona la categoría principal analizada, con sus respectivas subcategorías, según son percibidas por las diferentes cuotas. También se brindan algunos ejemplos de apartados del discurso aportado por los entrevistados - este se presentará mediante el número del documento primario y el número de la fila en el texto en su orden descendente, por ejemplo: (1:86)—. Finalmente, se mostrarán algunas diferencias encontradas, resaltando la relevancia 
que tiene cada categoría según el rol de la persona en la organización, la edad y el tiempo de vinculación en la misma.

\section{Compromiso}

En esta categoría se identificaron dos características principales: la primera relacionada con la disponibilidad de "estar dispuesto a todas las necesidades que surjan y compromiso incondicional" (1:279); la segunda relacionada con las responsabilidades que son delegadas, a través de las cuales se hacen conscientes de lo que pasa en su entorno social, ya que "al fin y al cabo ellos, estando en cosas puntuales en el mundo, por las que tienen que responder, se dan cuenta [de] lo que necesita el mundo juvenil en un momento determinado y entonces pueden aportar" (3:291).

\section{Disponibilidad}

Se evidencia que esta disponibilidad está caracterizada por tener tiempo y disposición para lo que se solicite, incluso sacrificar cosas externas a la organización por cumplir. Según los más jóvenes, se debe

\footnotetext{
Estar dispuesto a servir de la mejor manera cuando y donde se necesite, o sea cada vez que se tenga el tiempo, así toque sacrificar tiempo con la familia o perderse los paseos, toca porque me comprometí a eso (1:275). Cuando uno ama sacrifica todo o muchas cosas para servir a los demás (2:418). Cual refieren los adultos, uno hace lo mejor y da lo mejor que tiene según lo que se le es confiado (3:856). Se debe estar disponible para hacer lo que lo pongan hacer. (3:859)
}

Así, la disponibilidad se entiende como el modo de dedicar el tiempo personal que es sentido como libre a actividades de descanso, recreación y creación para compensarse, y es concebida como un nuevo derecho social de las personas a decidir cómo disponer del tiempo en el que el fin es, ante todo, la satisfacción de sí mismos.

\section{Responsabilidades}

Son entendidas como la acción de hacerse cargo de una actividad específica en la que las consecuencias recaen directamente en los individuos y no en las empresas propiamente, a fin de cumplir un objetivo o satisfacer una necesidad del contexto (Cancino del Castillo \& Morales, 2008). Se identificó que en la población voluntaria estas responsabilidades se ven influencias por el nivel de compromiso percibido con la organización y dependiendo del rol en que la ejecuten: 
La dinámica de las escuelas, los mismos roles que se nos son asignados, no solo algo específico, sino cada vez preparar más y cosas distintas, dependiendo del rol, eso es lo que distingue asumir más responsabilidades y si decido asumirlo, me genera más compromiso. (16:417)

También se limitan a acciones concretas "todo lo referente a la logística, preparación y demás en las actividades que se hacen durante una experiencia formativa” (3:959), y se dan proporcionalmente a la formación que la persona asuma dentro y fuera de la organización; además, son asumidas libre y voluntariamente:

Hay personas que realizan algunas actividades que no se les pueden dejar a otros, porque no tienen ni los conocimientos ni la formación en el momento dado, por ejemplo, dirigir un curso o realizar una actividad que puede ser muy activa o muy peligrosa o alguna cosa, entonces se le da a una persona que ya tenga un recorrido en la vida como joven. $(2: 135)$

\section{Expectativas}

Dentro de esta categoría previamente establecida se evidenció que las expectativas que tienen las personas como voluntarios se refieren principalmente al deseo de servicio, de aportar a las labores formativas de la organización y de tener un crecimiento personal "entonces ver, primero el impacto en mí y que podía contribuir de cierta forma para que otras personas tuvieran un encuentro tan significativo y una experiencia enriquecedora, eso me motivó mucho para hacerme voluntario" (3:156).

\section{Servicio}

A partir de los reportes de los voluntarios, el servicio se puede entender como toda acción que es de provecho para la obtención de un bien mayor común, a fin de realizar una auténtica y profunda transformación del entorno donde se ejecuta, dejándolo mejor de lo que lo han encontrado antes de realizar su quehacer: "veía la necesidad de las distintas personas, para que nos uniéramos y trabajar en pro de la juventud y tratar de cambiar su entorno" (1:65). De esta forma, el servicio deviene uno de sus principales motivadores: "me hice voluntaria también por ese deseo de querer hacer algo por los demás" (1:62), así como el medio para poder realizarse como persona e influenciar en la realidad de los otros:

Encontré que en esta organización podía hacerlo y podría aportar desde todo lo que había ido creciendo, servir a jóvenes de todo el país, eso fue una de las razones 
principales de decir que en este sitio yo podía aportarle a mucha más gente de eso que ya había recibido de tantas personas, de tantos voluntarios en el pasado. (3:168)

\section{Labores formativas}

Esta subcategoría se caracteriza por el apoyo social que el voluntario puede dar a otras personas: "aportamos en el proceso formativo de las personas que están en una vida fortaleciendo dinámicas comunitarias y también de las personas con las que tiene contacto" (3:447), y por su acción de brindar herramientas suficientes para que las personas con que se trabaja sean capaces de transformar su entorno: "hacemos que la persona se forme y allá en sus contextos haga lo propio, influya, sea un buen líder, crezca humanamente, crezca cristianamente y bueno, influya en su entorno, en sus amigos, en su familia, universidad, colegio, trabajo, etcétera" (3:344). La labor formativa se refleja en la medida en que se da valor al trabajo del otro, reconociendo y potenciando habilidades propias desde la particularidad de cada uno:

\footnotetext{
Es importante que los muchachos sepan que ellos son capaces de muchas cosas que en otros momentos nunca se les ha dado la oportunidad de descubrir, que son valiosos para las otras personas, que son valiosos para la institución, que son valiosos para sí mismos y que tienen valores. $(2: 191)$
}

\section{Crecimiento personal}

Se refiere a la formación de la madurez personal, social y comunitaria. En consecuencia, comprende los procesos pedagógicos de construcción de identidad que conducen al equilibrio emocional de todas las dimensiones de la persona, pues se evidencia la búsqueda constante de ser mejores personas de las que llegaron a la organización, logrando reflejar esos cambios en los diferentes contextos de su vida: "en la parte personal me ha cambiado mucho la forma de pensar, me ha permitido ver el mundo distinto y algunos comportamientos con mi familia han mejorado" (1:173); se logra también forjar criterios propios, habilidades y valores que guíen la totalidad de su vida: "inclusive indirectamente mi familia primaria, es decir mi esposa y mis hijas, han recibido esa formación... he podido aportarles y soy aceptado y tengo una autoridad verbal y moral dentro de esas personas" (2:146), así como otro tipo de cambios en varios ámbitos de la vida: "me ha llevado a creer nuevamente en las vocaciones, en los sacerdotes, mejorar mi madurez afectiva, a proyectarme y no pensar solo en el presente" (1:159). 


\section{Obligaciones}

En esta categoría, previamente establecida, no se identificaron subcategorías relevantes, pues todos los entrevistados refieren a aquella acción que realiza el individuo atendiendo a una necesidad de un contexto determinado en función de unas condiciones personales o contextuales y desde su rol dentro de la organización. Principalmente se refiere a ser ejemplo para otras personas desde los dones y habilidades que cada uno posee:

\section{Tengo un deber muy importante y es por medio de mi testimonio atraer más personas a lo que me gusta, no como traerlas, sino demostrarles esta forma de vivir y a lo que le apuesto yo, que también puede crecer en el corazón de otros. (3:1008)}

Siendo conscientes de que estas se dan en proporción de la formación que cada persona tiene y se sienta en el deber de poner al servicio de los demás: "se sienten en el deber de ser responsables de otras personas también, entonces se van creando como nudos para poder escalar más y ser cada vez mejores" (2:159).

\section{Permanencia}

Es una de las categorías emergentes del análisis realizado, y se relaciona con el acto de mantenerse en un lugar o acción determinada en el tiempo, por diferentes razones, que trae consigo ya sea beneficios, estabilidad social o emocional, reconocimiento, apoyo social, entre otros, y que resulta agradable para la persona. Esto está relacionado con la reciprocidad que encuentra con los otros voluntarios de la organización y con la disposición que cada persona tiene:

\footnotetext{
En primera instancia son las amistades que uno tiene en la organización, definitivamente sí, yo creo que cualquier voluntario que no tenga gente con la cual relacionarse o se sienta excluido, sencillamente no vuelve, no te están pagando, no estás recibiendo nada y no tienes algo que te vincule. (3:229)
}

\section{Reciprocidad}

Se identifica que los más jóvenes refieren que los vínculos establecidos con la organización son para toda la vida, que solo logran forjarse de manera auténtica en esta organización y en su quehacer como voluntarios los hace ser mejores personas: "ese vínculo de amistad que no solamente se hace en el diálogo con alguien, sino en esa construcción de un amigo más profundo" (3:572); "no llegan a ser solo compañeros 
de una luchas, sino llegan a ser casi hermanos y fuera de eso, se sienten responsables de hacerlos mejores personas" (2:158). Estos vínculos se crean por las relaciones que se dan al compartir un mismo espacio durante un tiempo prolongado: "las relaciones que se crean son muy fuertes, pues son amistades que duran mucho tiempo, a nivel personal son personas que han aportado mucho a mi vida y me mueven la vida, al final camino con ellos" (1:202); se logra también una unión a partir de una misma espiritualidad "es el Amigo en común el que hace que los lazos se creen tan fuertes y mantienen en muchas ocasiones el voluntariado, porque no siempre es fácil” (1:224).

\title{
Vocación
}

Se evidencia que los voluntarios le dan respuesta a su vocación personal, que se relaciona constantemente con el gusto que sienten al realizar las actividades encomendadas y pertenecer a la organización:

\begin{abstract}
Un llamado permanente en el que siento que mi vocación como mujer católica, yo la expreso desde acá, es un escenario en el que yo puedo digamos materializar la vocación por la cual me siento llamada a trabajar con los jóvenes, lo cual estoy convencida es necesario, que es importante, que da fruto, que se demora, se tarda, pero que vale la pena. $(3: 70)$
\end{abstract}

Por tanto, es lo que más los hace permanecer en la organización, pues refieren que su quehacer responde a un llamado: "yo estaba en décimo y seguí aquí, y así ha sido hasta el momento, porque es una de las formas de responderle a Dios, o sea mi vocación" (3:93), en el que se realizan como personas y encuentran el sentido a su vida: "para mí es responderle al Señor, y como nosotros estamos en estado de vocación, pues eso va generando una vinculación progresiva" (3:250).

\section{Vinculación afectiva}

Otra categoría emergente que caracteriza el contenido del contrato psicológico de los voluntarios es la vinculación afectiva que se genera tanto con los otros voluntarios como con la organización, relacionándose así con las promesas percibidas, el sentido de pertenencia y la espiritualidad de cada persona:

Yo desde que me vinculé diríamos que me enamoré de la obra como tal, porque me sentía siempre feliz, pleno, realizado en todo lo que yo tenía. (2:35). En el fondo de su corazón siempre van a sentir que hacen parte de una fundación que les ha dado mucho, en la cual ellos se han podido desarrollar como personas. (2:59) 


\section{Promesas}

Los voluntarios identifican promesas por parte de la organización hacia ellos relacionadas con su crecimiento personal e identidad propia y que los lleva a la felicidad: "que uno podía ser uno mismo, ser como yo era sin prejuicios" (1:364), "creo que más que ser una persona integral es que podía ser uno mismo, ser como yo era sin prejuicios" (1:234).

\section{Sentido de pertenencia}

Se refiere al sentido de implicación y vinculación de una persona en un sistema social, al experimentarse valorado, necesitado y aceptado por otros, lo que permite que la persona alinee y adhiera sus valores e identidad personal con los de la organización, brindándole bienestar y satisfacción personal (Dávila de León \& Jiménez, 2014). Este sentido se da en la medida en que los voluntarios se entregan a un mismo ideal y se vinculan a la organización en la que están:

\section{En el fondo de su corazón siempre van a sentir que hacen parte de una fundación que les ha dado mucho, en la cual ellos se han podido desarrollar como personas. (2:315). Que así como muchos han entregado mucho por ese ideal, que amen la organización tanto como los que ya están, es decir crear un fuerte sentido de pertenencia y sirvan respondiendo a esto, así como todos los que han pasado. (1:305)}

Asimismo, la pertenencia se da en la medida en que los voluntarios creen en que lo que hace la organización genera un cambio social: "como yo creo en la obra, yo creo en lo que hace, quiero aportarle, porque veo resultados" (3:1034) y en la medida en que los voluntarios identifican que pueden ser ellos mismos en cualquier lado por lo que han aprendido en su quehacer como voluntarios:

\footnotetext{
Quedan como marcados el tiempo que estuvieron en la Central, eso no es algo que olviden, uno se encuentra personas que hace 20 años que no ha visto y sin embargo la tienen en su corazón. (2:98). Pues si se van es muy difícil que vayan creciendo en la formación con uno, a lo que nosotros llamamos formación, pero ya van con la semilla.
} $(2: 106)$

\section{Espiritualidad}

Para Koenig, McCullough y Larson (citados por Quinceno \& Vinaccia, 2009), la espiritualidad es la búsqueda que cada persona hace a fin de entender la relación entre respuestas a los cuestionamientos del sentido de su vida y lo sagrado o lo trascendente, 
que puede o no conducir al desarrollo de rituales religiosos y la formación de una comunidad. La espiritualidad significa dirigir la vida y el desarrollo espiritual y de las acciones según las enseñanzas y normas de, en este caso, Dios.

Los voluntarios reportan que la espiritualidad se basa en vivir y servir en la organización acorde a los valores de su creencia espiritual: "la fe, la oración y esa comunicación con Dios es lo que te hace siempre seguir el ideal de la central, que es pues estar en el acompañamiento de un joven en el crecimiento personal e integral de uno" (3:1022).

\section{Prácticas sociales}

Las prácticas sociales son acciones sistemáticas que incluyen componentes físicos, mentales y emocionales de las personas, que cuales implican formas de entender el mundo, siendo así un conjunto de acciones interrelacionadas (Barajas, 2016) que son resultado de la historia de aprendizaje y del contexto social en el que son aprendidas. En el caso de los voluntarios de la organización, estas prácticas se relacionan con el estatus percibido, el reconocimiento que se da de su quehacer, las creencias que se adoptan y la confianza que se tiene en la entidad.

\section{Estatus}

Se puede entender como aquella posición social que adquiere una persona por acuerdo de las personas que lo rodean en un contexto social determinado, según el rol que cumplan dentro de este, que no se limita a tener un nivel económico, social o cultural específico, sino que involucra también lo que la comunidad crea relevante y meritorio para otorgarlo, en este caso por el tiempo y calidad de formación y del servicio dado en la organización:

\footnotetext{
Entiendo el estatus como digamos la posición de cada uno, una posición de responsabilidad en la organización, y por esa posición, por esa responsabilidad, los demás le atribuyen una valoración y tanto la responsabilidad, la posición y esa valoración, pues terminaría generando el estatus (3:241). Los niveles de estatus acá no son pues como se entienden en cualquier figura de otra organización, yo sé que aquí son como niveles de servicio (3:249). Creo que el estatus depende de la calidad del servicio, en cuanto a las diferentes formas de servir durante un tiempo. (1:302)
}

Quien más estatus tiene se vuelve un modelo de autoridad moral y verbal para los otros voluntarios: 
Esa experiencia que han adquirido con el tiempo les da la posibilidad de compartir las experiencias y que el joven tenga apertura a estas, eso es clave, es decir que entre más dan a conocer lo que saben, entre más lo ponen al servicio, más estatus tienen, y entre más experiencia pues más comparten y más autoridad moral son para los jóvenes, porque guían en cada cosa. (1:310)

\section{Reconocimiento}

Se entiende como la distinción o mérito que se le otorga a una persona, ya sea por la excelente ejecución de una tarea asignada o por estar vinculado a situaciones u organizaciones particulares, se puede dar a través de refuerzos sociales o tangibles: "en el trabajo pastoral que realizo en mi ciudad, uno resalta y permite que uno sea más escuchado en la toma de decisiones, eso ha brindado un voto de confianza en las actividades que hago" (1:189). Para los voluntarios, el reconocimiento es dado por las mismas personas con y por las que trabajan y brindan su tiempo y servicio:

Yo siento que el reconocimiento lo he recibido son las expresiones de gratitud de los jóvenes que participan en las experiencias, creo que es el mejor (1:194). Yo creo que el mayor reconocimiento que yo he recibido en mi vida es que la mayoría, no podría decir el $100 \%$ me quiere, los muchachos y las muchachas así me conozcan poco o me conozcan más, nunca me siento rechazado por ellos, antes me buscan (2:106).

Así como por su entorno social más cercano como su familia y amigos "se da desde nuestras familias cuando compartimos nuestras experiencias" (1:187), "desde mi familia, porque se sienten felices de que ayude a los otros desde acá” (1:193).

\section{Creencias}

Según lo reportado, se identifica como el conjunto de principios y valores que una persona considera verdaderas frente a una situación particular, que moldean su comportamiento y se consideran influyentes al momento de tomar decisiones en su vida:

Pero siempre recibí esa formación del fundador, de creer que nunca nos va a faltar y de hecho nunca nos ha faltado en la organización (2:118). La prosperidad acarrea el desastre, porque cuando uno tiene malgasta o cree que porque tiene puede hacer todo (2:120). Yo creo que la peor cosa que puede ocurrir es que la gente se sienta empleada, es decir yo hago algo pero espero una remuneración económica, que es distinto a yo hago algo y me estoy enriqueciendo espiritual y al mismo tiempo humanamente. $(2: 133)$ 
Se evidencian las mismas reglas en su sistema de creencias, referido a la importancia de tener un mismo ideal, una misma espiritualidad y disposición para el servicio: "entonces sentí que se podía construir y que los sueños e ideales que uno tenía para empezar a dejar un mundo mejor sí eran posibles entonces desde ahí me conecté" (3:54).

\section{Confianza}

La confianza es el cúmulo de expectativas positivas que se tienen sobre las acciones de otras personas, es decir, es una actitud que se asume sobre el comportamiento futuro de otra persona a pesar de no tener la certeza y el control sobre el rumbo que tomará dicho comportamiento (Contreras, Díaz \& Sáenz, 2017) o en este caso la organización:

\footnotetext{
Confíen en la obra, en el futuro de la obra, porque está pensada y organizada de tal forma que se construye todos los días, en la que la misma dinámica muestra que personas son las idóneas para vincularse y quedarse, por lo que es importante que confíen en las personas que están, así tengan discrepancias con ellas, esas mismas diferencias son las que enriquecen, pero todo eso se logra si se confía totalmente en el otro y en la obra. $(2: 144)$
}

A partir de una mirada global sobre los resultados expuestos anteriormente, en relación con el número de palabras codificadas, se realizó la búsqueda sobre las cincuenta palabras más frecuentes de cinco o más caracteres, a fin de identificar la saturación de las categorías identificadas en el contrato psicológico de los voluntarios entrevistados, ante lo cual se puede observar cómo predominan conceptos como "voluntario", "tiempo", "jóvenes", "formación", “equipo", "estatus", "vocación” y "servicio" (ver figura 2). La marca de nube señala cómo las expectativas del quehacer del voluntario se relacionan con el tiempo que se destina para servir a otros en equipo, lo cual permite generar amistades:

Me motivó fundamentalmente como joven ocupar mi tiempo, realizar actividades como campamentos o deportes, donde podía conocer a otras personas y trabajar en equipo con ellas, poniendo al servicio después de un tiempo lo que íbamos aprendiendo a otros. $(2: 15)$ 


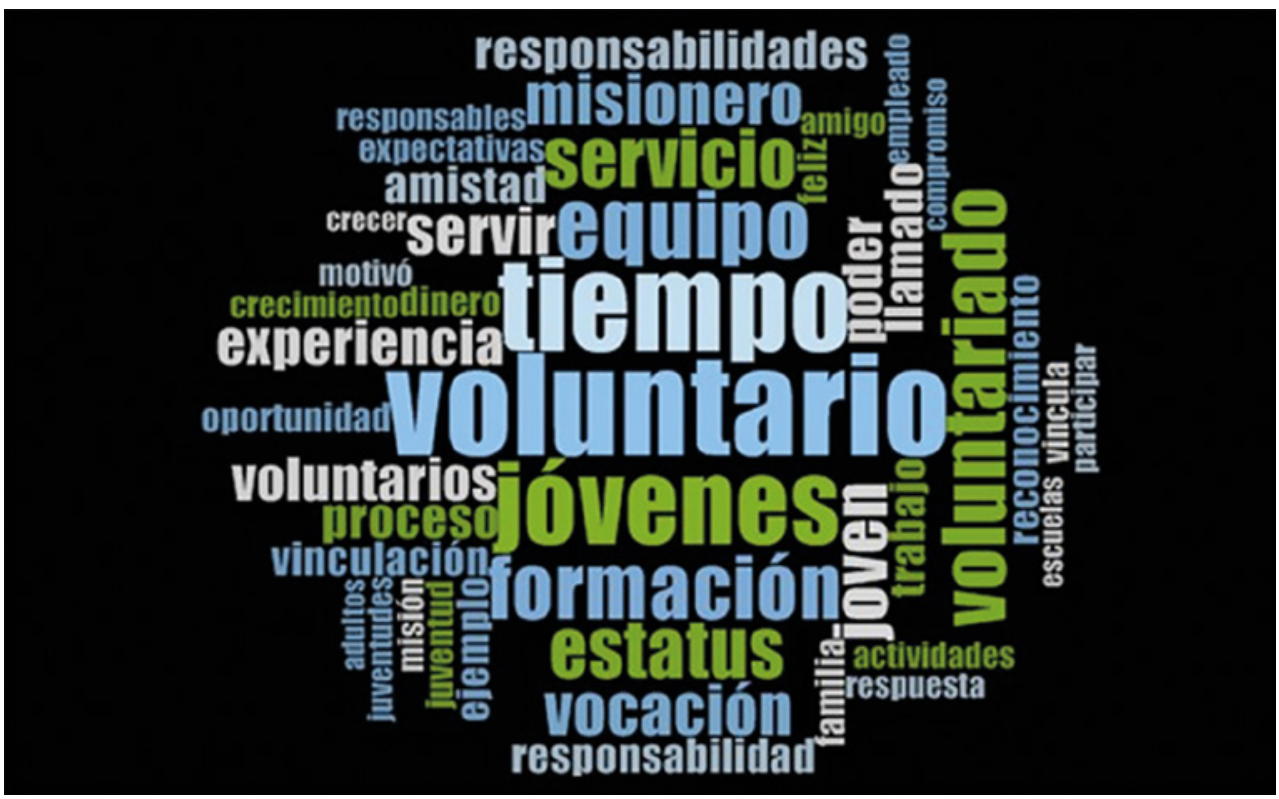

Figura 2. Conceptos predominantes en el contenido del contrato psicológico en voluntarios. Fuente: Elaboración propia

Por otra parte, la marca de nube indica una relación estrecha entre "formación" y "estatus": "el estatus más alto que hay en la organización lo tienen aquellas personas que precisamente han dedicado casi toda su vida a servir de diferentes formas en ella y por tanto tienen más formación que el resto" (1:302); así como entre "vocación", "responsabilidad", "respuesta" y "joven": "la opción preferencial que se tiene por los jóvenes en la organización, que reafirman nuestra vocación, a través de las responsabilidades que nos confían y asumimos de la mejor manera, evidenciando el impacto que se logra en sus vidas"(1:101).

\section{Características según el rol dentro de la organización}

Se identifica que una de las características más importantes tanto para los voluntarios del staff y los líderes más jóvenes son las expectativas que se tienen, a diferencia de los vitalicios, en quienes predomina el sentido de pertenencia. Asimismo, que hay una similitud en la relevancia que tiene, para los líderes jóvenes y los vitalicios, el crecimiento personal que pueden llegar a tener en la organización, teniendo una mayor incidencia en los adultos del staff, además de que comparten la misma percepción de importancia de las obligaciones que se generan durante su voluntariado (véase figura 3). 


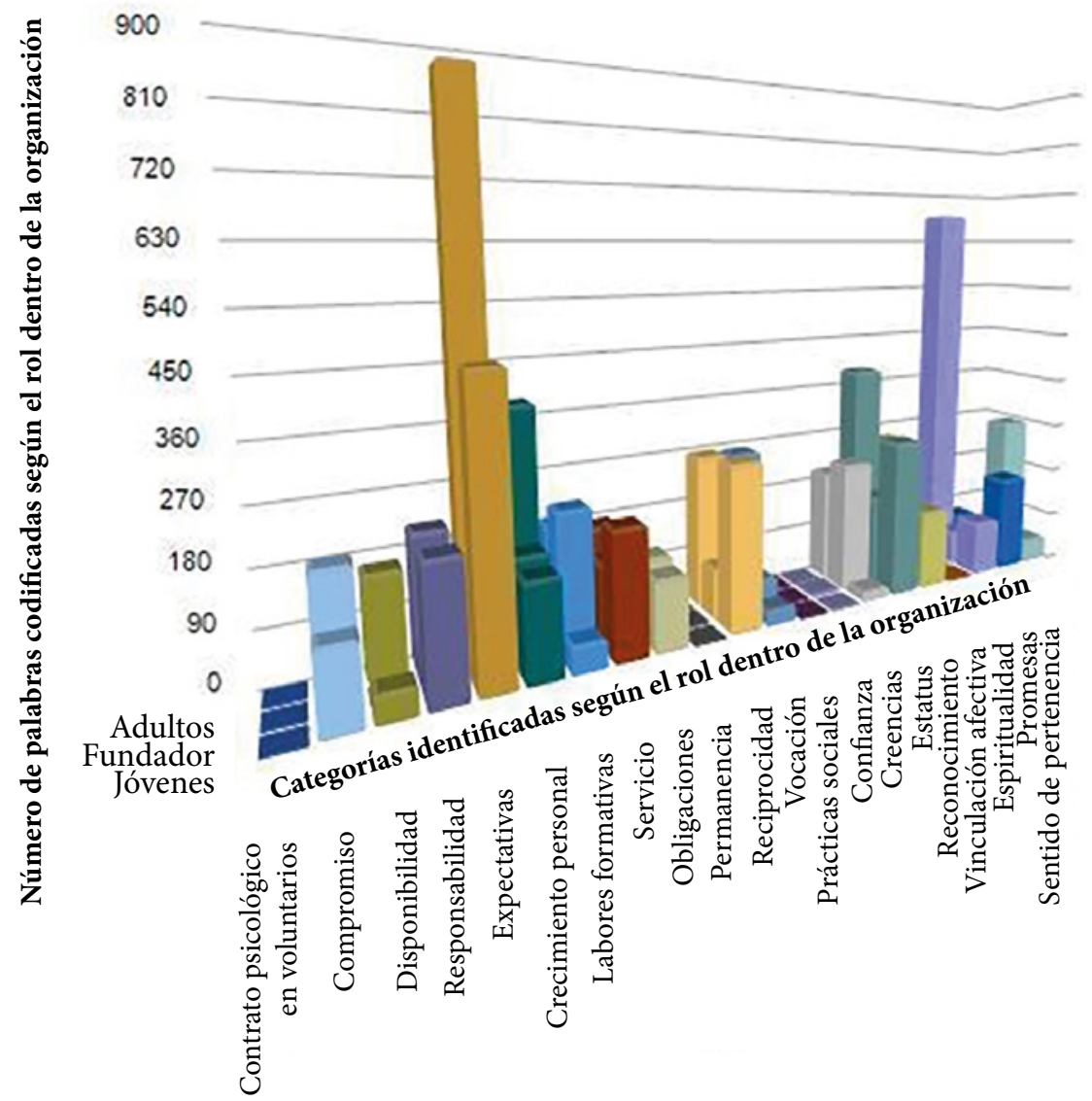

Figura 3. Número de palabras codificadas en cada categoría según el rol del voluntario dentro de la organización. Fuente: elaboración propia.

Se identifica que la cuota de vitalicios (fundadores) se caracteriza por una larga permanencia temporal en la organización (más de cincuenta años). Su contrato psicológico se caracteriza principalmente por un alto sentido de pertenencia a la organización, que se relaciona con las labores formativas y su sistema de creencias para permanecer en ella, lo que acarrea un nivel de compromiso relevante con la misma. La confianza, la vocación y la responsabilidad son las categorías menos relevantes en el contenido de su contrato psicológico, aunque cabe resaltar que la confianza, a pesar de ser una de las características con menor incidencia en su discurso en relación con las otras, es la única que emerge en este grupo de voluntarios, es decir, se vuelve relevante en comparación a los contratos psicológicos de los otros voluntarios (ver figura 4). 


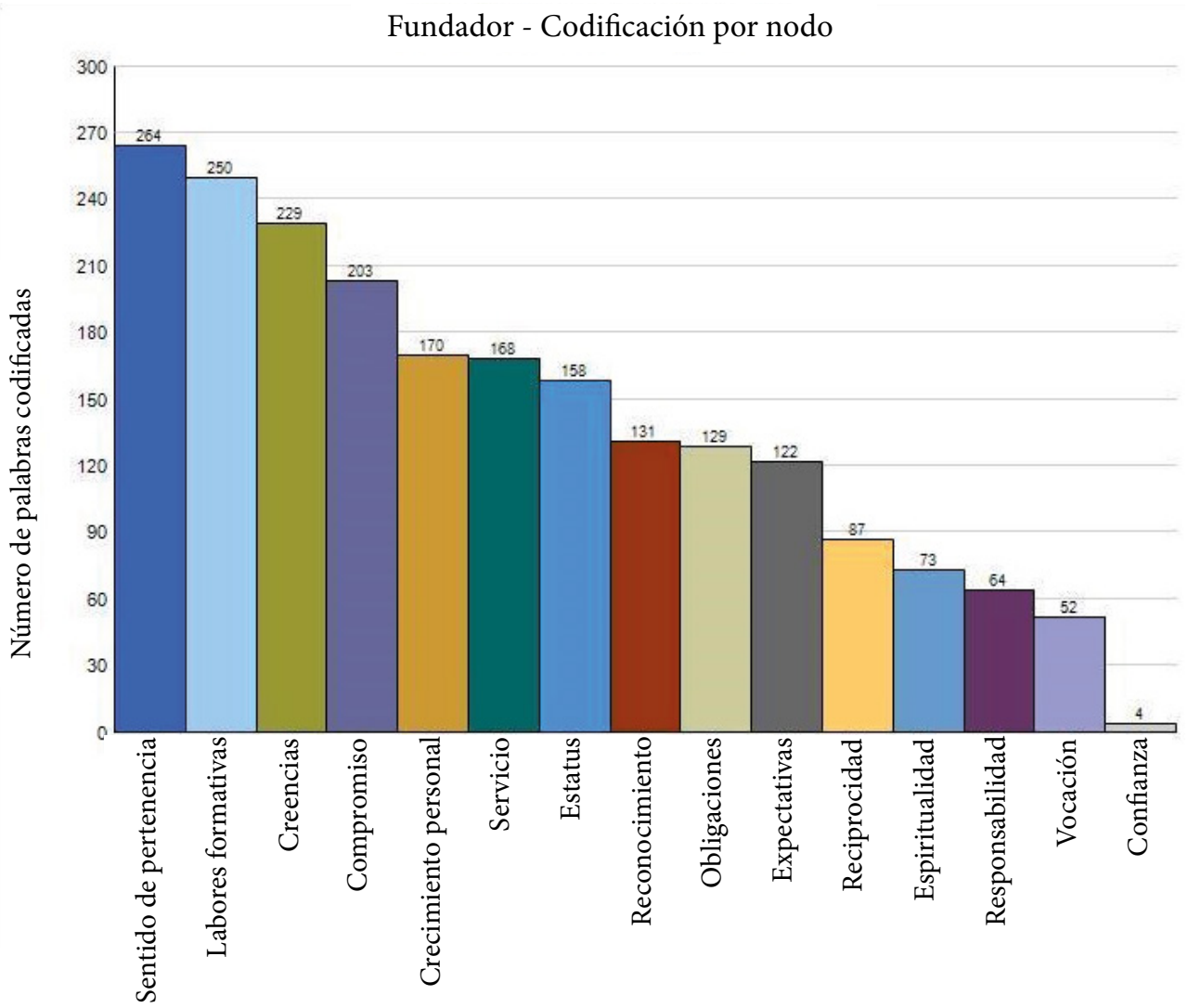

Figura 4. Número de palabras codificadas en los voluntarios vitalicios de la organización. Fuente: elaboración propia.

En relación con las generaciones más adultas, que llevan vinculadas en promedio un tiempo entre diez y cuarenta años a la organización, se identifica un contenido del contrato psicológico caracterizado principalmente por las expectativas que tienen frente a la ejecución y el rol que tienen dentro de la organización. Otros valores significativos son su sistema de creencias espirituales y estatus percibido y recibido por su quehacer como voluntario después de cierto tiempo; sin embargo, y a diferencia de los líderes jóvenes, las obligaciones, responsabilidades y el compromiso son las categorías menos relevantes en su quehacer como voluntarios (ver figura 5). 


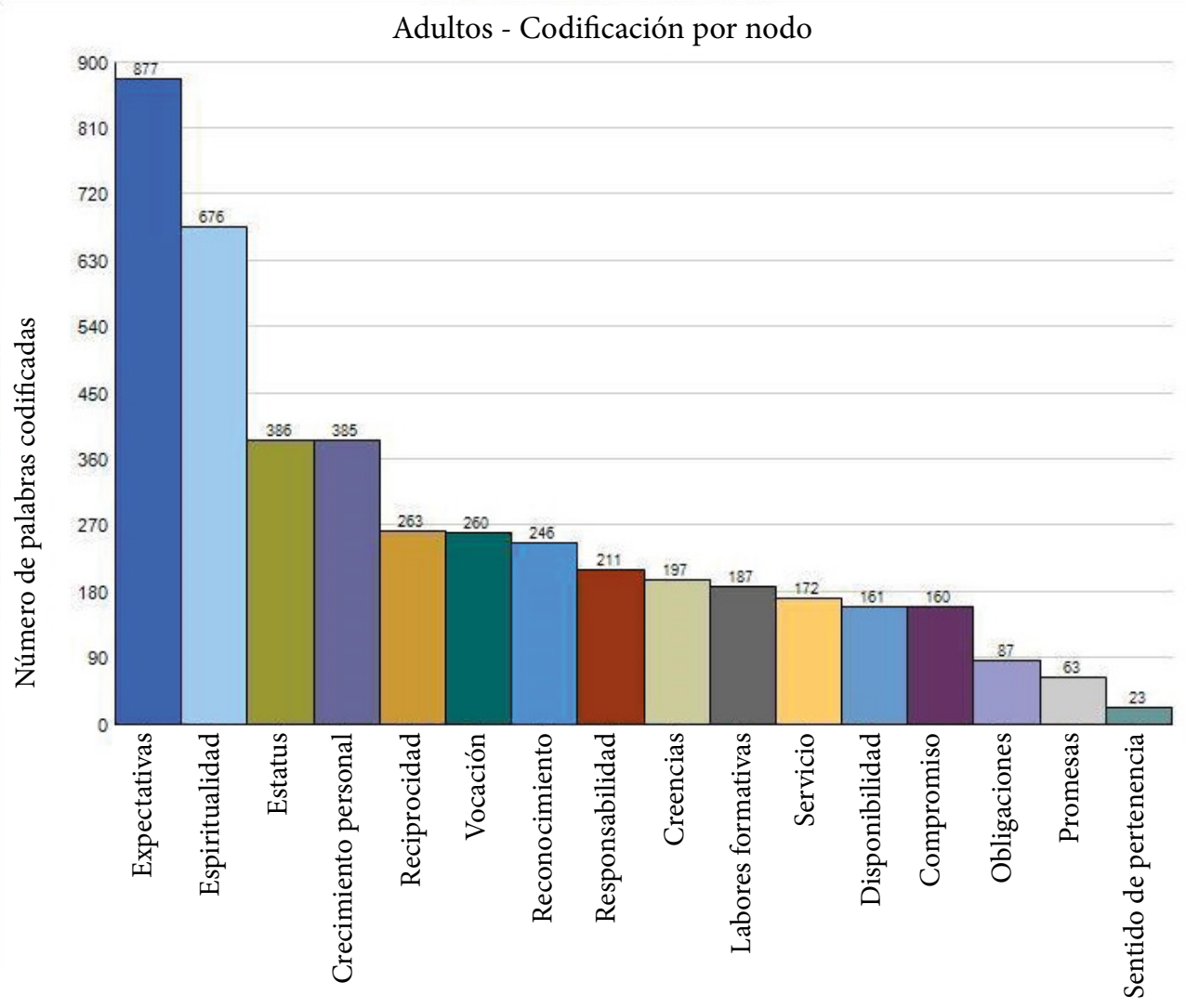

Figura 5. Número de palabras codificadas en los voluntarios del staff de la organización. Fuente: elaboración propia.

Se encuentra que en los líderes más jóvenes estos acuerdos implícitos con la organización se dan con relación a las expectativas que tienen frente al servicio que pueden ofrecer a las otras personas y al compromiso que adquieren principalmente por la reciprocidad que encuentran, entendida como aquellas relaciones o vínculos interpersonales profundos que denominan amistad. Otros aspectos relevantes son las responsabilidades que les son delegadas y la percepción de un estatus muy marcado dentro de la entidad, siendo este último un indicador de autoridad moral y mayor nivel formativo. Por lo anterior, se puede identificar que la relevancia de las responsabilidades que le son delegadas se relaciona con que los hace sentir que hacen parte de una comunidad y que adquieren reconocimiento dentro y fuera de la organización. Las creencias, la espiritualidad, el sentido de pertenencia y las labores formativas que se ejercen, son las características menos relevantes en el contrato psicológico de esa generación (ver figura 6). 


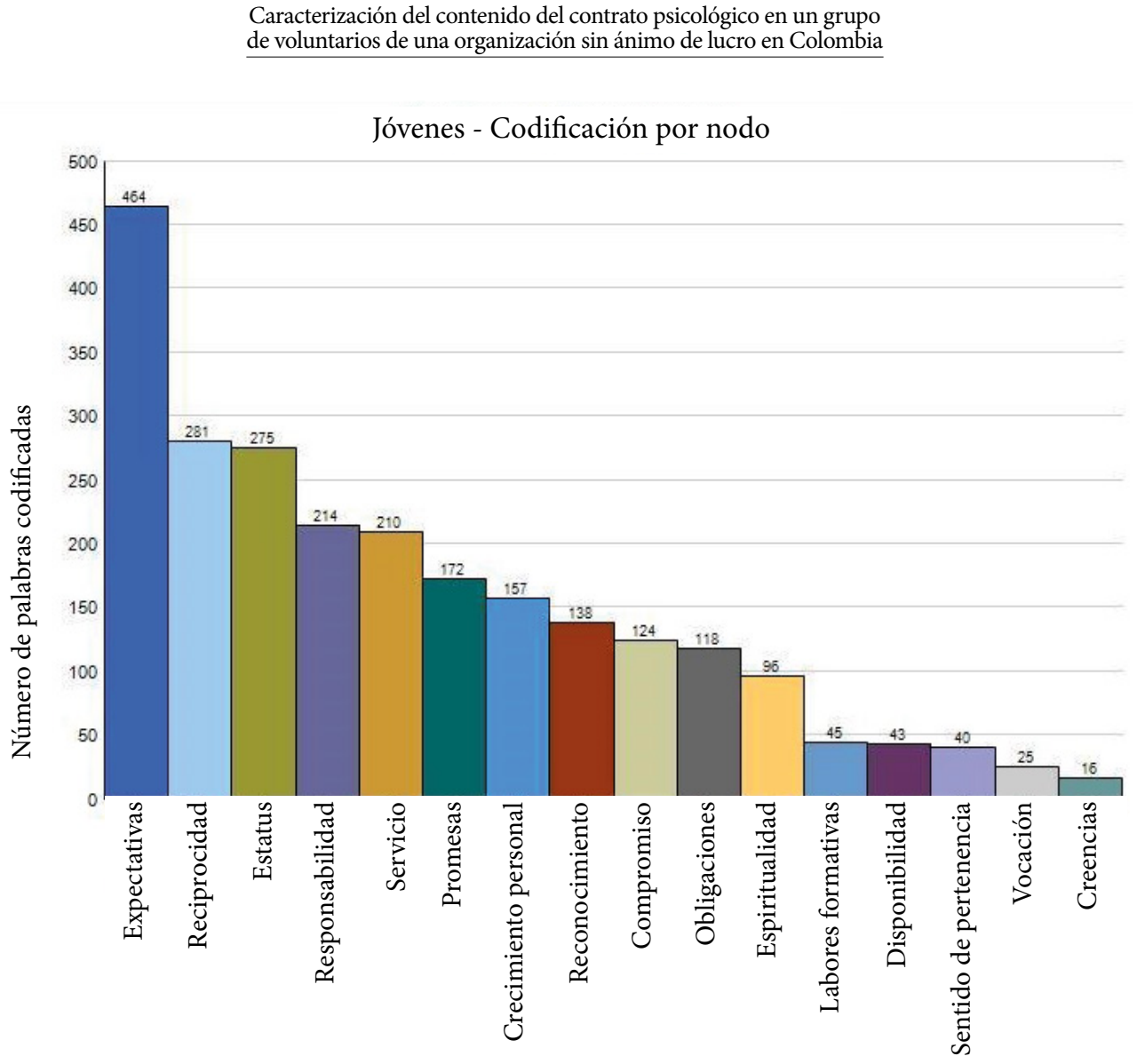

Figura 6. Número de palabras codificadas en los voluntarios líderes de la organización. Fuente: elaboración propia.

\section{Conclusiones}

Con la intención de responder al interrogante: ¿qué caracteriza el contenido del contrato psicológico en un grupo de voluntarios de una organización sin ánimo de lucro en Colombia?, se realizó un análisis cualitativo inductivo, bajo la luz de la teoría fundamentada. Los resultados identificaron seis rasgos principales del contenido del contrato psicológico de esta población, de los cuales tres fueron previamente preestablecidos (compromiso, expectativas y obligaciones) y tres fueron características emergentes (permanencia, vinculación afectiva y prácticas sociales) durante el proceso de análisis de la información recolectada.

De las características previamente establecidas, se identificó que en esta modalidad de trabajo informal las expectativas que se generan entre el voluntario y la organización 
son lo más importante al momento de la formación del contrato psicológico, relacionadas principalmente con el crecimiento personal que perciben pueden tener en la organización. Lo que confirma que el trabajo, en este caso las labores formativas y el servicio que brindan, potencia el desarrollo psicológico, generando en los trabajadores independencia y libertad al decidir sobre sus propias vidas, en especial en los más jóvenes (Domínguez, 2008). Esto explica la manifestación de las subcategorías emergentes relacionadas con las expectativas de la muestra.

En relación con las categorías emergentes, se evidencia que tanto la vinculación afectiva que se da por las promesas, la espiritualidad y el sentido de pertenencia de las personas, así como las prácticas sociales que se dan dentro de la entidad basadas en las creencias, el reconocimiento, el estatus y la confianza percibidas, se asocian con las características propias de la cultura y el clima organizacional de la entidad. Se corrobora que las características del contrato psicológico están moldeadas por las situaciones, el cumplimiento de acuerdos y el contexto social donde se pacte este tipo de contrato, influyendo directamente en elementos adicionales que permiten su continuidad y duración del contrato (Bello, Guerrero, Prado \& Santamaría, 2017).

También se identificó que la permanencia para esta modalidad de trabajo se da principalmente por la reciprocidad que se encuentra en los lazos interpersonales que se crean durante el quehacer, lo cual sugiere que "el intercambio relacional favorece el establecimiento de lazos afectivos y la aparición de tendencias de afiliación" (Böhrt, Solares \& Romero, 2014, p. 37). Esto implica que la evolución del contrato psicológico y el compromiso organizacional cambian con la edad y la antigüedad en la organización.

Se evidenciaron diferencias en la forma como las personas de distintas generaciones vinculadas a la organización perciben el contenido del contrato psicológico, identificando que la antigüedad de vinculación y la edad son factores importantes en la formación del contrato; este hallazgo corrobora los resultados de la investigación de Böhrt, Solares y Romero (2014), quienes señalan que las variables edad y antigüedad se entienden como trasformaciones acumulativas en el tiempo de vida del individuo o de la vinculación en la organización, que tienen una incidencia relevante en la formación y cumplimiento del contrato psicológico.

Partiendo de las diferencias generacionales que se evidencian en la información recolectada, se puede decir que las características del contrato psicológico varían dependiendo del tiempo de permanencia que una persona lleve en la organización. A pesar de que la mayoría de los entrevistados se vincularon a la organización en un promedio de edad similar, entre los 13 y 20 años, sus contratos psicológicos difieren en relación con su momento de vida actual, pues en el análisis realizado se 
identificaron discrepancias relevantes en su contrato psicológico. De otro lado, también se corrobora lo planteado por Torres, Santa y Bonilla (2014), quienes respecto a las expectativas muestran que los trabajadores más antiguos son más leales y comprometidos, mientras que los recién vinculados se concentran en su propio éxito, las responsabilidades que se delegan y el crecimiento personal y profesional que logren, lo cual se evidencia en la modalidad laboral del voluntariado.

Se encuentra que el contrato psicológico para los adultos que llevan vinculados más de diez años como voluntarios se caracteriza principalmente por un discurso enmarcado en su espiritualidad, a diferencia del fundador, en el cual prima la labor formativa y la responsabilidad en los más jóvenes, confirmando que, como afirman Harman y Doherty (2014), el contrato psicológico en voluntarios se caracteriza por buscar nuevas alternativas para ejecutar sus responsabilidades e innovar; esto reafirma que el contenido del contrato psicológico varía en cada población y se vuelve específico a una modalidad de trabajo.

Otra explicación a estas diferencias encontradas en las muestras según la edad, puede deberse a que, según Bolea (citado por Bello, Guerrero, Prado \& Santamaría, 2017), los profesionales que nacieron entre 1945 y 1960 fueron criados en un contexto social caracterizado por las diversas dificultades económicas en los años de posguerra. Esto ocasionó que las personas no tuvieran la oportunidad de estudiar e iniciaron la vida laboral muy jóvenes y de forma rápida, lo que les permitió desarrollar repertorios conductuales de esfuerzo; son personas que permanecen gran parte de su vida en una misma empresa y asumen de forma adecuada situaciones de cambio, a diferencia de las generaciones posteriores a estas fechas.

Finalmente, resaltamos la importancia que tiene realizar este tipo de estudios en las nuevas realidades laborales y en modalidades de trabajo caracterizadas no necesariamente por contratos de trabajo formal sino a través de relaciones mucho más informales. En el caso presentado, el voluntariado constituye una nueva modalidad de trabajo en el mundo contemporáneo, pues las personas que lo realizan no se vinculan contractualmente de manera formal a una institución, no esperan remuneración económica y se comprometen establemente en la prestación de servicios principalmente sociales. Estos tipos de relacionamiento generan en las personas nuevas dinámicas sociales e impactos psicológicos que los cuales pueden ser analizados a la luz de diferentes constructos, como lo es el contrato psicológico, considerado en los últimos tiempos un concepto clave para entender el comportamiento de las personas vinculadas a una organización. 


\section{Referencias}

Alcover, C. (2002). El contrato psicológico, el componente implícito de las relaciones laborales. Aljibe.

Barajas Sandoval, L. C. (2016). Prácticas sociales y cuerpos recuperados: reconfigurar lo propio para sobrevivir. Nómadas, 45, 253-262. http://www.scielo.org.co/pdf/noma/n45/ n4e5a17.pdf

Barreto, I., Velandia, A. \& Rincón, J. (2011). Estrategias metodológicas para el análisis de datos textuales: aplicaciones en psicología del consumidor. Suma Psicológica, 18(2), 7-15.

Bello, A., Guerrero, S., Prado, C. \& Santamaría, D. (2017). Contrato psicológico, un reto para las diferentes generaciones en la empresa Racafe \& CIA S.C.A. (Tesis de Especialización). Universidad Piloto de Colombia, Facultad de Ciencias Humanas. http://polux.unipiloto.edu.co:8080/00003811.pdf

Betanzos Díaz, N., Andrade Palos, P. \& Paz Rodríguez, F. (2006). Compromiso organizacional en una muestra de trabajadores mexicanos. Revista de Psicología del Trabajo y de las Organizaciones, 22(1), 25-43.

Betanzos, N. \& Paz, F. (2007). Análisis psicométrico del compromiso organizacional como variable actitudinal. Anales de Psicología, 23(2), 207-215.

Böhrt, R., Solares, L. \& Romero, C. (2014). Evolución del contrato psicológico y el compromiso organizacional con la edad y la antigüedad. Ajayu - Órgano de Difusión Científica del Departamento de Psicología de la Universidad Católica Boliviana San Pablo, 12(1). http://www.redalyc.org/html/4615/461545457001/

Cancino del Castillo, C. \& Morales Parragué, M. (2008). Responsabilidad social empresarial. Santiago: Departamento de Control de Gestión y Sistemas de Información de la Facultad de Economía y Negocios de la Universidad de Chile. http://repositorio.uchile.cl/ bitstream/handle/2250/122747/Cancino_Morales_2008.pdf

Cantisano, G., Fernández, I. \& Lisbona, A. (2005). Ruptura de contrato psicológico y burnout en equipos de intervención en emergencias y catástrofes. Ansiedad y estrés, 11, 265-279.

Cardozo, S. (2016). Contenido y estado del contrato psicológico de los funcionarios de la Gobernación de Caldas. (Trabajo de grado en Especialización en Gerencia del Talento Humano). Universidad de Manizales. Facultad de Ciencias Sociales y Humanas. https:// ridum.umanizales.edu.co/xmlui/handle/20.500.12746/2675

Contreras, Y. , Diaz, F. \& Sáenz, M. (2017). Confianza y confiabilidad: recursos estratégicos para la competitividad y continuidad de la empresa familiar en México. Red Internacional de Investigadores en Competitividad, 5(1). https://riico.net/index.php/riico/article/ view/601/802

Creswell, J. W. (2008). Research design: qualitative, quantitative, and mixed methods approaches. SAGE. 
Dávila de León, C. \& Jiménez García, G. (2014). Sentido de pertenencia y compromiso organizacional: predicción del bienestar. Revista de Psicología (PUCP), 32(2), 271-302. http:// www.scielo.org.pe/scielo.php?pid=S0254-92472014000200004\&script=sci_arttext

Dabos, G. \& Rousseau, D. (2004). Mutuality and reciprocity in the psychological contracts of employees and employers. Journal of Applied Psychology, 89, 52-72.

Díez, R. (2015). Análisis del contrato psicológico: el caso de Brico Depôt. (Tesis de pregrado en Administración y Dirección de Empresas). Facultad de Ciencias Económicas y Empresariales Universidad de León.

Domínguez, L. G. (2008). Jóvenes, políticas de empleo y subjetividad: una mirada a los nuevos programas de inserción laboral para jóvenes cubanos a través del sentido del trabajo. Revista Argentina de Sociología, 6(11), 169-191.

Gil, T. \& Cano, A. (2010). Introducción al análisis de datos en investigación cualitativa: Tipos de análisis y proceso de codificación (II). Nure Investigation, 45, 1-10.

Gómez y Olave, P. \& Mielgo Martínez, E. (1989). Voluntariado y trabajo social. Cuadernos de Trabajo Social, 2, 79-88.

Harman, A. \& Doherty, A. (2014). The psychological contract of volunteer youth sport coaches. Journal of Sport Management, 28(6), 687-699.

Kim, M., Trail, G., Lim, J. \& Kim, Y. (2009). The role of psychological contract in intention to continue volunteering. Journal of Sport Management, 23(5), 549-573.

Liao-Troth, M. (2001). Attitude differences between paid workers and volunteers. Nonprofit Management and Leadership, 11(4), 423-442.

Martínez, N. (2015). Reseña metodológica sobre los grupos focales. Editorial Universidad Don Bosco, 6(9), 47-53.

Quinceno, J. \& Vinaccia, S. (2009). La salud en el marco de la psicología de la religión y la espiritualidad. Diversitas, 5(2), 321-336. http://revistas.usantotomas.edu.co/index.php/ diversitas/article/view/261/439

Ramos, A. (2012). Efectos del contrato psicológico en una organización no lucrativa. (Tesis Doctoral). Universidad Autónoma de Nuevo León.

Ruiz, J. (2012). Metodología de la investigación cualitativa. Universidad de Deusto.

Sánchez, M. \& Berrocoso, J. (2017). Diyers en la tercera ola: un estudio de casos para el análisis de entornos de aprendizaje autorregulados, conectados y distribuidos. CIAIQ, Congreso Ibero-Americano de Investigación Cualitativa, 5: 86-95 [FCL3] https://proceedings. ciaiq.org/index.php/ciaiq2017/article/view/1322

Stirling, C., Kilpatrick, S. \& Orpin, P. (2011). A psychological contract perspective to the link between non-profit organizations' management practices and volunteer sustainability. Human Resource Development International, 14(3), 321-336.

Strauss, A., Corbin, J. \& Zimmerman, E. (2002). Bases de la investigación cualitativa: técnicas y procedimientos para desarrollar la teoría fundamentada. Universidad de Antioquia. 
Tena, G. (2002). El contrato psicológico: relación laboral empresa-trabajador. Acciones e Investigaciones Sociales, 15, 85-107.

Torres Oviedo, C. F., Santa Mosquera, V. \& Bonilla Arias, J. A. (2014). Caracterización del contrato psicológico de empleados de dos generaciones en una organización del sector bancario. Cuadernos de Administración, 30(51).

Vélez, M. (2017). Sobre el sentido del trabajo en la flexibilidad laboral en Medellín, Colombia. Equidad y Desarrollo, 29, 83-104.

Vesga, J. J. (2007). Contenido y extensión del contrato psicológico en distintas modalidades de trabajo. Perspectivas en Psicología, 10, 77-99.

Vesga, J. J. (2014). Evolución histórica del concepto “contrato psicológico”. En J. Orejuela (ed.). Psicología de las organizaciones y del trabajo. Apuestas de investigación (pp. 243-260). Universidad de San Buenaventura. 



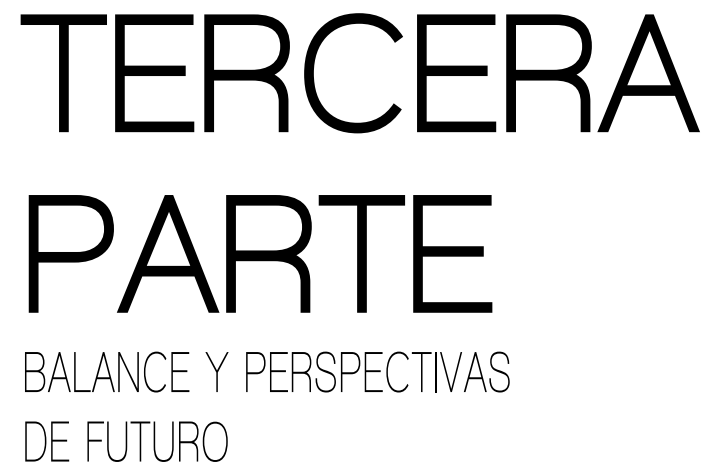





\section{9 \\ EL LARGO PASADO Y LA CORTA HISTORIA DEL CONTRATO PSICOLÓGICO Y LAS RELACIONES EMPLEADO-ORGANZACIÓN}

Carlos-María Alcover*

Universidad Rey Juan Carlos, Madrid

\section{Introducción}

Desde el inicio del trabajo asalariado o por cuenta ajena, las relaciones empleado-empleador se han caracterizado por un doble componente: el explícito, que en su acepción formal alude al contenido del contrato legal, compuesto por una serie de cláusulas que definen y limitan los términos de la relación de intercambio aceptada libremente entre las partes, $y$ en su modalidad menos formal se refiere al acuerdo verbal entre ambas; y el implícito, relativo al conjunto más o menos definido de expectativas, promesas, obligaciones o comportamientos esperados que cada una de las partes formula privadamente respecto a lo que se espera recibir y se está dispuesto a dar en el marco de la relación de intercambio regulada por el contrato de trabajo. Este segundo componente, siempre presente de manera tácita en toda relación laboral, no contó con un término ni una definición más o menos precisa hasta bien avanzada la segunda mitad del siglo XX, cuando varios autores comenzaron a referirse a él denominándolo contrato psicológico. Así pues, se trata de un componente presente en toda relación laboral establecida entre un empleado y un empleador con un largo pasado, pero con una corta historia, y con un futuro cierto mientras se mantengan relaciones de intercambio entre individuos, aunque esté sometido a una continua discusión y necesidad de redefinición. Sin duda, las relaciones laborales actuales no son las mismas que hace medio siglo, puesto que, como señalaba Kompier (2006), "el mundo del trabajo ha cambiado porque el mundo ha cambiado" (p. 422).

Así, la mayor parte de las organizaciones en la actualidad presenta estructuras más horizontales y con límites difusos, donde los empleados y las unidades de trabajo a

* https://orcid.org/0000-0001-9632-9107 
las que pertenecen mantienen vínculos muy débiles entre sí y con la propia organización. Estas estructuras flexibles se ven facilitadas por las tecnologías de la comunicación, que permiten el trabajo a distancia, y por una organización del trabajo basada en proyectos temporales o cíclicos, de modo que los empleados trabajan con otros durante periodos de tiempo limitados e incluso forman parte simultáneamente de varios equipos o proyectos (Shore et ál., 2004). En consecuencia, las relaciones empleado-organización actuales se caracterizan por una mayor flexibilidad, por la existencia de vinculaciones triangulares (empleados contratados por un empleador que prestan sus servicios en una organización diferente), por relaciones temporales $o$ parciales (profesionales libres que se vinculan con empresas para la prestación de un servicio o el desarrollo de un producto de manera puntual), y por carreras abiertas caracterizadas por la movilidad, los vínculos con diferentes empleadores y los cambios de orientación profesional (Baruch \& Rousseau, 2019; Chambel \& Alcover, 2011; Rodrigues \& Guest, 2010; Zaleska \& De Menezes, 2007). Como señalan los expertos en este ámbito (Shore et ál., 2004), las características del trabajo, de las organizaciones y de las modalidades de contratación modifican el significado de los contratos psicológicos (a nivel individual) y las propias relaciones laborales (a nivel grupal o colectivo).

Tres décadas de investigación sobre el contrato psicológico han permitido acumular una amplia evidencia sobre este constructo y los procesos comportamentales y organizacionales asociados a él. Aunque el término se propuso ya en la década de los sesenta (Argyris, 1960, Levinson, Price, Munden \& Solley, 1962, Schein, 1965), la línea de investigación más moderna, impulsada por Rousseau (1989), ha resultado de un elevado valor heurístico y de una gran utilidad para la comprensión de las relaciones entre los individuos y las organizaciones en las que trabajan (Conway \& Pekcan, 2019; Coyle-Shapiro \& Parzefall, 2008; Kraak \& Linde, 2019).

No obstante, la conceptualización del contrato psicológico no ha estado exenta de controversias y de planteamientos discrepantes (Arnold, 1996; Conway \& Briner, 2005; Conway \& Pekcan, 2019; Cullinane \& Dundon, 2006; Griep \& Cooper, 2019; Guest, 1998; Hansen, 2019), fundamentalmente en cuanto a su contenido, su medida y a otros elementos ambiguos, como se analizará a lo largo del capítulo. Esto ha dado lugar a diferentes operacionalizaciones en la investigación empírica, puesto que ha sido medido como las creencias de los empleados acerca de las expectativas, las promesas y las obligaciones contenidas en la relación laboral (Rousseau, Tomprou \& Hansen, 2018). Mientras que las propuestas iniciales de los autores de la década de los sesenta se basaban en las expectativas mutuas entre los empleados y sus supervisores -o la "organización"-, Rousseau (1989) orientó el término hacia las promesas, lo que ponía el acento en cómo los empleados y, especialmente, los agentes 
organizacionales, construyen el contrato psicológico a partir de las promesas explícitas e implícitas transmitidas entre las partes, las cuales se convierten en obligaciones (Coyle-Shapiro, Costa, Doden \& Chang, 2019; Rousseau, 1995). La concepción de Rousseau del contrato psicológico ponía el énfasis en su carácter individual, subjetivo, basado en las percepciones acerca de la relación, las cuales generaban creencias. Tanto su definición inicial como su posterior reformulación mantenían la misma perspectiva: un contrato psicológico se definía como las

\footnotetext{
... creencias del individuo acerca de los términos y condiciones de un acuerdo de intercambio recíproco entre la persona focal y la otra parte. Un contrato psicológico emerge cuando una parte cree que se ha hecho una promesa de futuras compensaciones, se ha realizado una contribución y, en consecuencia, se ha creado una obligación de proporcionar beneficios futuros. (Rousseau, 1989, p. 122)
}

Este conjunto de creencias constituye un esquema cognitivo (Rousseau, 2001), y como tal se configura a partir de distintas fuentes, tanto internas (por ejemplo, las experiencias recordadas) como externas (es decir, los resultados de la relación establecida en el marco del contrato de trabajo), las cuales se modifican a lo largo del tiempo (Rousseau, Tomprou \& Hansen, 2018). Fundamentalmente a partir de las percepciones e interpretaciones del empleado de las observaciones, informaciones y conversaciones intercambiadas con los diferentes agentes organizacionales, desde los más próximos (reclutadores y seleccionadores, supervisores o compañeros) hasta los más alejados (gerentes, administradores o directores de la organización), el contrato psicológico se forma y existe en el ojo del observador (Herriot, 1998; Rousseau, 1989). En consecuencia, "la percepción de mutualidad, y no necesariamente la mutualidad, es de hecho el corazón del contrato psicológico" (Rousseau, 1998, pp. 665-666). Es un enfoque que se mantenía tras una fructífera década de investigación:

\footnotetext{
Un contrato psicológico alude a la creencia individual acerca de las obligaciones mutuas existentes entre la persona y la otra parte, tal como un empleador, ya se trate este de una firma o de otra persona. Esta creencia se basa en la percepción de que se ha realizado una promesa (por ejemplo, relativa a un empleo o a las oportunidades de desarrollar una carrera) y se ha ofrecido una consideración de intercambio por ella (por ejemplo, aceptando un puesto, rechazando otras ofertas de empleo), lo que une a las partes a través de una serie de obligaciones recíprocas. (Rousseau \& Tijoriwala, 1998, p. 679)
}

A pesar de que un contrato psicológico necesariamente implica la participación de varios agentes, la investigación tradicional tendió a simplificar la perspectiva de análisis (Alcover, 2002; Alcover, Rico, Turnley \& Bolino, 2017a; Knapp, Diehl \& Dougan, 
2020; Marks, 2001). Así, los contratos psicológicos eran operacionalizados desde la perspectiva del trabajador (Rousseau, 1990), del empleador (Coyle-Shapiro, 2002), o de ambos (Dabos \& Rousseau, 2004). En todos los casos, los contratos psicológicos cumplen dos funciones clave (Hiltrop, 1995): primero, definen la relación de empleo entre las partes, y segundo, establecen las expectativas mutuas que moldean el comportamiento. El contexto desempeña un papel crítico relacionado con ambas funciones, puesto que condiciona las interpretaciones y valoraciones de las experiencias laborales (Chaudhry, Wayne \& Schalk, 2009; Kraak \& Linde, 2019). De esta manera, el contrato psicológico es un regulador central de las relaciones empleado-organización (Coyle-Shapiro, 2002; Rousseau, 2001), y se ha considerado que influye sobre las actitudes y comportamientos de los empleados con respecto a la construcción de confianza, lo que a su vez genera compromiso y cooperación (Malhotra \& Murnighan, 2002). Además, los beneficios implícitos o explícitos prometidos brindan a las partes implicadas un incentivo para actuar recíprocamente y para aportar algo a cambio de lo recibido (Dabos \& Rousseau, 2004).

La lógica implícita en este enfoque se basa en la premisa de que cada empleado individual y la "organización" establecen una relación. Sin embargo, dado que las organizaciones están formadas por múltiples agentes con los que potencialmente pueden realizarse intercambios, no resulta evidente a quién(es) considera cada empleado cuando define con qué agente(s) organizacional(es) establece la relación (CoyleShapiro \& Shore, 2007). También se ha cuestionado si la "organización" puede tener un contrato psicológico (Conway \& Briner, 2005, 2009; Guest, 1998), ya que supondría un obvio antropomorfismo de dudosa entidad científica. En particular, el elemento de la agencia múltiple, o múltiples stakeholders, es uno de los más relevantes en la redefinición actual del constructo (Alcover et ál., 2017a, 2017b; Baruch \& Rousseau, 2019; Bordia, Restubog, Bordia \& Tang, 2010; Conway \& Pekcan, 2019; Knapp, Diehl \& Dougan, 2020), y constituye el primero de los ejes que identifican el carácter del presente y del futuro de la investigación.

Directamente relacionado con él, el segundo eje se articula en torno a la consideración temporal y dinámica del contrato psicológico. Por supuesto, esta perspectiva no es nueva, ya que desde sus inicios se incluyó en los modelos (Levinson et ál., 1962). Sin embargo, la perspectiva de la agencia múltiple incrementa la complejidad del dinamismo de las relaciones empleado-agentes organizacionales y la consideración del tiempo. Mientras que en los enfoques tradicionales la relación empleado-organización se consideraba como un proceso en el que se encontraban implicadas dos partes, con una dinámica que se modificaba en mayor o menor medida a lo largo del tiempo en función del grado de cumplimiento o ruptura/violación (Chaudhry et ál., 2009; Morrison \& Robinson, 1997; Rousseau, 2001), la nueva perspectiva multifoco 
permite captar que, por ejemplo, simultáneamente un empleado perciba que una(s) partes cumplen mientras que otra(s) no lo hacen, y que dichos cumplimientos/rupturas se sucedan o se combinen de manera tanto sincrónica como asincrónica. La dimensión temporal del contrato psicológico permite analizar cómo los empleados conviven y se adaptan a relaciones ambivalentes de cumplimiento/incumplimiento, a la alternancia de ambos por parte de los mismos agentes a lo largo del tiempo, e incluso cómo las relaciones y el contrato psicológico se redefinen después de haber experimentado su violación sin que el vínculo laboral se rompa (Kraak \& Linde, 2019; Tomprou, Rousseau \& Hansen, 2015). Este dinamismo y temporalidad complejos constituyen en consecuencia el segundo de los ejes identificados en este análisis.

En tercer lugar, los cambios en las relaciones laborales, en las modalidades de contratos y en los diferentes vínculos que los trabajadores establecen con sus empleadores y con las organizaciones, han tenido como una de sus consecuencias la progresiva individualización de las relaciones laborales y la reducción de la normatividad que las regulan (Bal \& Hornung, 2019), lo que también tiene su impacto en los contratos psicológicos (D’Art \& Turner, 2006; Guest, 2004). Este hecho ha provocado la emergencia del constructo denominado acuerdo idiosincrásico (i-deals), referido a los términos especiales de empleo negociados directamente entre un trabajador $y$ su empleador, actual o futuro (Rousseau, Ho \& Greenberg, 2005). El término i-deal no solo alude al carácter idiosincrásico, sino también al supuesto carácter ideal que tiene el acuerdo para ambas partes (Rousseau, 2005). En este tipo de relaciones, como más adelante se analizará, el contenido del contrato psicológico se convierte en algo fundamentalmente explícito, por lo que en realidad su carácter se desvirtúa o al menos se debilita, ya que se negocian y se acuerdan los términos que ambas partes se comprometen a aportar y a recibir en la relación laboral.

El principal objetivo de este capítulo se centra en analizar las implicaciones de estos tres ejes para el presente y el futuro de la investigación sobre el contrato psicológico.

\section{Agencia múltiple o múltiples stakeholders en el contrato psicológico}

Las relaciones laborales han cambiado significativamente en las últimas décadas, tanto en los países industrializados como en los países en desarrollo, con una creciente tendencia hacia lo que internacionalmente se denominan "relaciones laborales no estándares" (non-standard forms of employment). Según la Organización Mundial del Trabajo, "estas nuevas formas comprenden básicamente cuatro acuerdos de empleo diferentes que se desvían de la 'relación laboral estándar', entendida como un trabajo a tiempo completo, indefinido, así como parte de una relación subordinada entre un 
empleado y un empleador" (International Labour Organization - ILO, 2016, p. xxi). Las cuatro modalidades de empleo no estándar se configuran en torno a la temporalidad (por ejemplo, contratos a plazo fijo, incluidos los contratos basados en proyectos o tareas, trabajo estacional, trabajo informal, incluido el trabajo diario), el trabajo a tiempo parcial y a demanda (por ejemplo, con menos horas normales de trabajo que las equivalentes a tiempo completo, empleo marginal a tiempo parcial, trabajo a demanda, incluidos los contratos de cero horas, o contratos abiertos), las relaciones laborales triangulares o con múltiples partes (también conocidas como formas de externalización y subcontratación -en inglés, dispatch, brokerage y labour hire-, los empleos a través de agencia temporal, y la mano de obra contratada en varios niveles de subcontratación), y las formas encubiertas e irregulares (trabajos sin contrato, autoempleo dependiente, falso o no clasificado) (ILO, 2016). En estos contextos, los empleados suelen depender simultáneamente de varios agentes, que representan a una o más organizaciones, que asignan tareas y objetivos, supervisan el trabajo y proporcionan recompensas (o imponen sanciones) según los resultados.

Como se ha señalado, las investigaciones previas generalmente suponían que cada empleado establece un contrato psicológico con la "organización", considerada como la otra parte en una relación bilateral. Como consecuencia de ello, a menudo se da por sentado que la organización está representada por una sola persona (con mayor frecuencia, el supervisor directo del empleado o el gerente de línea) (Lester, Turnley, Bloodgood \& Bolino, 2002; Petersitzke, 2009), quien tiene el poder de tomar todas las decisiones que afectan al empleado y a su contrato psicológico (Alcover et ál., 2017a). Sin embargo, esta relación diádica entre el empleado y la organización no captura el alcance total del contexto social que surge en el curso de las interacciones entre diferentes agentes, ni aborda todos los procesos de comparación social que pueden influir en la formación y desarrollo del contrato psicológico (Henderson, Wayne, Shore, Bomme \& Tetrick, 2008). En las organizaciones contemporáneas es más probable que los empleados mantengan múltiples relaciones con diversos agentes organizacionales (Chambel \& Alcover, 2011; Dawson, Karahanna \& Buchholtz, 2014; Knapp, Diehl \& Dougan, 2020; Lapalme, Simard \& Tremblay, 2011), cada uno de los cuales posee un grado diferente de poder y autoridad para tomar decisiones (Conway \& Briner, 2005). Por lo tanto, en los contextos actuales, la identidad del(los) agente(s) organizacional(es) que representa(n) a la empresa o corporación se convierte en una cuestión clave (Alcover et ál., 2017a), al igual que la redefinición de la carrera laboral/profesional que implica la múltiple agencia, las múltiples relaciones laborales y la múltiple pertenencia a diversas organizaciones (Baruch \& Rousseau, 2019; Knapp, Diehl \& Dougan, 2020; Reader, 2018) para la configuración de los contratos psicológicos. 
La consideración de la agencia múltiple tiene una gran trascendencia para la comprensión y para la investigación relativa al contrato psicológico, no solo en los casos de las múltiples relaciones simultáneas con diferentes empleadores (Raeder, 2018) o de las relaciones triangulares o de subcontratación, sino también en el desarrollo de contratos psicológicos múltiples en la relación laboral única de un empleado con una organización (Knapp, Diehl \& Dougan, 2020). Esta perspectiva de los múltiples focos (Alcover et ál., 2017a, 2017b; Marks, 2001) subraya la necesidad de identificar los diversos agentes organizacionales involucrados en los procesos relacionados con la formación y el desarrollo de los contratos psicológicos. Estos agentes juegan un papel importante durante las primeras etapas de la socialización y continúan actuando como referentes diferenciados durante el desarrollo del contrato psicológico. Además, estos agentes a menudo son responsables en diferente grado del cumplimiento/ruptura del contrato psicológico. Al mismo tiempo, esta perspectiva de múltiples focos propone que diferentes agentes organizacionales pueden influir en última instancia en las actitudes y comportamientos de los empleados de diferentes maneras con base en el concepto de similitud de objetivos (Lavelle, Rupp \& Brockner, 2007). Además, el enfoque también reconoce que es muy probable que las percepciones de los intercambios sociales de los empleados con un agente organizacional particular afecten a sus actitudes y comportamientos hacia ese agente (Masterson, Lewis \& Goldman, 2000). Por otra parte, esta perspectiva también considera que tanto la naturaleza de los contratos psicológicos que se forman con diferentes partes como el grado en que se pueden cumplir van a depender tanto del poder y del estatus de cada trabajador individual en la estructura organizacional - formal e informal- como del grado de influencia y control que ejercen los agentes organizacionales (Alcover et ál., 2017b). Estas relaciones de múltiples focos ponen en primer plano cuestiones de estatus y poder en las relaciones laborales, anteriormente ausentes en la investigación sobre los contratos psicológicos (Baruch \& Rousseau, 2019).

El enfoque de la agencia múltiple también tiene una serie de implicaciones para la gestión de los contratos psicológicos en las organizaciones actuales (Alcover et ál., 2017a). Por una parte, la posibilidad de comprender cómo la naturaleza y la calidad de las relaciones de los empleados con sus compañeros de equipo, supervisores directos y otros agentes organizacionales influyen en sus percepciones de lo que comprende el contrato psicológico y su cumplimiento, podría ayudar a los gerentes a comprender y predecir mejor las actitudes, intenciones y comportamientos laborales de los empleados. Al mismo tiempo, identificar los múltiples focos de los intercambios y los contenidos específicos vinculados con cada uno de los stakeholders implicados permitiría una comprensión más precisa de las fuentes de cumplimiento/incumplimiento y, por lo tanto, debería ayudar a aumentar la conciencia gerencial sobre cómo 
fortalecer o restaurar las relaciones e intercambios entre empleados y otros agentes de la organización, y lograr así mayor congruencia de metas entre todas las partes implicadas (Alcover et ál., 2017a; Baruch \& Rousseau, 2019).

Por otra parte, este enfoque también proporciona una visión más holística de la experiencia laboral y de las relaciones empleado-organización (Shore, Coyle-Shapiro \& Tetrick 2012), porque integra no solo las percepciones sobre el contenido de los intercambios entre los empleados y la organización, sino también los procesos involucrados en la comparación con otros referentes - como son otros compañeros con quienes hay cohesión (referentes socioemocionales y de identidad) y otros compañeros jerárquicamente equivalentes (referentes estructurales)—; la calidad de las relaciones con compañeros de trabajo, supervisores y otros agentes organizacionales; las percepciones de justicia organizacional en todos los niveles; y los procesos involucrados en la identificación organizacional y del equipo de trabajo. Una visión integrada también permitirá a los gerentes comprender mejor el clima organizacional y la cultura específica asociada con cada contexto de trabajo, y diseñar acciones para intervenir y cambiar las facetas del contexto de trabajo que potencial o actualmente perjudican las relaciones entre los miembros de la organización (Alcover et ál., 2017a). Relacionado con ello, también los gerentes pueden comprender mejor los contratos psicológicos de los trabajadores que tienen relaciones laborales no estándares, en particular aquellos que simultáneamente trabajan para varias organizaciones, que pueden percibir (y responder) a los cumplimientos y las rupturas del contrato psicológico de forma diferente a como lo pueden hacer los trabajadores que mantienen una relación laboral única (Knapp, Diehl \& Dougan, 2020; Raeder, 2018). En este sentido, la flexibilidad de estos trabajadores y su capacidad para adaptarse o cambiar de empleos pueden aproximar sus contratos psicológicos a las modalidades de acuerdos idiosincrásicos ( $i$-deals) ya mencionados, puesto que poseen más capacidad para negociar las condiciones de empleo más favorables para ellos y para las organizaciones que les contratan.

En definitiva, la perspectiva de la agencia múltiple o múltiples stakeholders debería facilitar un diagnóstico más completo y preciso de los procesos involucrados en las relaciones, expectativas e intercambios que afectan a múltiples agentes organizacionales, y por lo tanto podría resultar una herramienta útil para el diseño posterior de medidas para mejorar la calidad de las experiencias en los cambiantes contextos laborales de hoy (Alcover et ál., 2017a; Knapp, Diehl \& Dougan, 2020; O'LearyKelly, Henderson, Anand \& Ashforth, 2014). En particular, como señalan Baruch y Rousseau (2019), los trabajadores, los empleadores y otros stakeholders podrían ayudarse mutuamente a anticipar cambios futuros en la relación laboral y en la carrera 
profesional y valorar, discutir y negociar formas de responder a las necesidades cambiantes de cada uno.

\section{Carácter temporal y dinámico del contrato psicológico}

El segundo eje de la investigación actual y futura se configura a partir de una mayor consideración del carácter temporal y dinámico de los contratos psicológicos (Griep, Vantilborgh, Hansen \& Conway, 2018; Kraak \& Linde, 2019). Este enfoque se consolida fundamentalmente a partir de las aportaciones del modelo dinámico del contrato psicológico de Schalk y Roe (2007), del modelo posviolación propuesto por Tomprou Hansen y Rousseau (2015) y del modelo de fases dinámicas de los procesos del contrato psicológico formulado por Rousseau, Tomprou y Hansen (2018).

A pesar de que el constructo es por naturaleza dinámico, la investigación tradicional, lastrada por la prevalencia de los diseños transversales en la mayor parte de la investigación, solo permitía obtener fotografías estáticas de la relación empleado-empleador, ignorando que tanto esta relación como el contrato psicológico inevitablemente cambian a lo largo del tiempo (Rousseau, Tomprou \& Hansen 2018). Los contratos psicológicos comienzan a formarse en un determinado momento (desde el propio proceso de reclutamiento y selección) al comienzo del proceso de socialización (Delobbe, Cooper-Thomas \& De Hoe, 2016), son sensibles a las decisiones de los responsables de recursos humanos (Aggarwal \& Bhargava, 2009), así como a las características de las relaciones que se establecen con los agentes organizacionales, pueden experimentar incumplimientos que provocan la percepción de ruptura (cognitiva) y de violación (emocional), y pueden ser abandonados y olvidados (Schalk \& Roe, 2007). Según estos últimos autores, existen básicamente tres patrones de respuesta del trabajador a los cambios del empleador en cuanto a las obligaciones contenidas en el contrato psicológico: balance (positivo y negativo), revisión (positiva y negativa) y abandono. Cuando los cambios y las discrepancias entre las percepciones y las expectativas son mínimas, el trabajador suele llevar a cabo pequeñas acciones correctoras que no modifican sustancialmente el contrato psicológico. Por el contrario, ante situaciones nuevas o inesperadas, $o$ ante desviaciones significativas del empleador acerca del contenido del contrato psicológico, el trabajador puede implicarse en acciones correctoras que implican un cambio sustancial del mismo. Schalk y Roe (2007) consideran que las personas en general intentan encajar los eventos percibidos en el esquema cognitivo, esto es, en el contrato psicológico (Rousseau, 2001), mientras continúen percibiéndolo como válido, de modo que este margen puede considerarse como una "zona de aceptación" (Schalk \& Roe, 2007), definida por los correspondientes "límites de aceptación” que mantienen el contrato psicológico sin 
cuestionarlo. En consecuencia, en situaciones más o menos estables la persona procesa de manera automática los eventos que afectan a la relación y obtiene un balance (positivo o negativo) que mantiene el contrato psicológico y no pone en riesgo la relación laboral. Por el contrario, cuando las desviaciones del empleador se perciben como inapropiadas o intolerables, el trabajador experimenta que se ha sobrepasado el "límite de aceptación". En este caso, el procesamiento cognitivo de los eventos es mucho más detallado y se experimenta un cambio en el contrato psicológico, que lleva a una revisión de su contenido, pero siempre que las desviaciones sean moderadas y se mantengan en los límites de lo aceptable, de modo que su contenido pueda ser negociado para definir un nuevo contrato psicológico. Por el contrario, si se percibe que los cambios de la conducta del empleador son drásticos o intolerables y superan los "límites de tolerancia", el contrato psicológico se abandona, de modo que el trabajador considera que tampoco está obligado a cumplir con sus obligaciones y su compromiso se reduce al mínimo que permita mantener la relación laboral sin vulnerar lo establecido en el contrato legal (Schalk \& Roe, 2007). En caso de que el incumplimiento del contrato psicológico se considere intolerable y existan alternativas razonables de cambiar de empleo, el trabajador abandonará la relación laboral.

Sin embargo, también es posible que tras experimentar una ruptura y una violación del contrato psicológico la relación laboral no se rompa, puesto que las reacciones y respuestas a una ruptura no son idénticas (Dulac, Coyle-Shapiro, Henderson \& Wayne, 2008), y el trabajador decide continuar en la organización. Para comprender qué ocurre en estas situaciones y cómo evoluciona en el tiempo este tipo de relaciones, Tomprou, Hansen y Rousseau (2015) propusieron el modelo de posviolación del contrato psicológico. La investigación previa había documentado con precisión las consecuencias de las percepciones de ruptura y violación (Bal, De Lange, Jansen \& Van Der Velde, 2008; Coyle-Shapiro et ál., 2019; Zhao, Wayne, Glibkowski \& Bravo, 2007), experiencia que no puede considerarse como un evento discreto sino como un proceso a través del cual el trabajador toma conciencia y elabora las cogniciones, emociones y acciones acerca de lo ocurrido (Parzefall \& Coyle-Shapiro, 2011): reducción del compromiso y de las obligaciones sentidas hacia el empleador (Eisenberger, Armeli, Rexwinkel, Lynch \& Rhoades, 2001; Schalk \& Roe, 2007), cinismo y desconfianza (Andersson, 1996; Robinson \& Morrison, 2000; Robinson \& Rousseau, 1994), sentimientos de haber sido traicionado (Morrison \& Robinson, 1997) y, como consecuencia de todo ello, intenciones o conductas dirigidas a tomar venganza de los agentes organizacionales o de la "organización" mediante acciones negligentes y contraproductivas en general (Bordia, Restubog \& Tang, 2008; Griep \& Vantilborgh, 2018; Jensen, Opland \& Ryan, 2010; Restubog, Zagenczyk, Bordia, Bordia \& Chapman, 2015). Estas consecuencias pueden llevar al abandono de la relación laboral si el 
trabajador no tolera lo ocurrido y se dan las condiciones para ello al contar con alternativas de otro empleo (Turnley \& Feldman, 1999). Sin embargo, el conocimiento acerca de los procesos posteriores a estas experiencias de violación del contrato psicológico cuando la relación laboral no se rompe apenas se habían analizado hasta ahora.

Al igual que lo planteado en el modelo de Schalk y Roe (2007), solo las discrepancias significativas entre el contrato psicológico y las conductas y decisiones actuales de los agentes organizacionales activan las percepciones de ruptura (cognitivas) y generan las reacciones emocionales de ansiedad, angustia, resentimiento y distrés que constituyen la experiencia de violación, provocando una disrupción del contrato psicológico (Tomprou, Hansen \& Rousseau, 2015). Según las autoras, esta disrupción inicia en la víctima un proceso de autorregulación motivado por la búsqueda de equilibrio cognitivo y emocional, mediante el cual persigue intencionadamente la resolución de la violación y la reducción o eliminación del afecto negativo generado por ella mediante el restablecimiento de un contrato psicológico con el empleador. Así, el proceso de

\footnotetext{
... resolución de la violación se refiere a la percepción de la víctima de que la discrepancia entre el contrato psicológico original y las experiencias reales se ha reducido y el efecto negativo asociado se ha disipado. Como tal, la resolución de la violación ocurre a través de la reducción tanto de la discrepancia percibida (cognición) como del afecto negativo (emociones). (Tomprou, Hansen \& Rousseau, 2015, p. 564)
}

El siguiente paso en el proceso se refiere a la probabilidad que percibe la víctima de que la violación se resuelva, probabilidad que depende de la percepción de la capacidad de respuesta organizacional (reconocimiento de la violación y esfuerzo de la organización por repararla), de la rapidez de la resolución y de los recursos disponibles, tanto organizacionales (fundamentalmente, el apoyo de los compañeros y los superiores) como personales (optimismo, control percibido y autoeficacia, entre otros). En función de la probabilidad percibida de la resolución de la violación, la víctima optará por diferentes estrategias de afrontamiento, así como condicionará el esfuerzo invertido por ella para resolverla. Estas estrategias se diferencian por el grado en que afrontan o evitan el estresor, es decir, la violación del contrato psicológico. Las estrategias de afrontamiento incluyen las dos modalidades bien conocidas en la literatura sobre el estrés: el afrontamiento centrado en el problema, que se dirige a las discrepancias percibidas en el contenido del contrato psicológico, y el afrontamiento centrado en la emoción, que persigue disminuir o eliminar el afecto negativo. Por su parte, las estrategias de evitación incluyen el distanciamiento o la desconexión mental y conductual, y su principal objetivo es permitir que la víctima evite 
el factor estresante (la violación) y el afecto negativo asociado a él (Tomprou, Hansen \& Rousseau, 2015). Como predice el modelo del estrés en el que se basan (Carver \& Scheier, 1994; Lazarus \& Folkman, 1984), las estrategias de afrontamiento tenderán a ser más eficaces que las estrategias de evitación en la resolución de la violación (véase también Bankins, 2015), si bien la eficacia de las primeras estará moderada por el grado en que la víctima perciba capacidad de respuesta organizacional. Por último, Tomprou, Hansen y Rousseau (2015) proponen que el nuevo o redefinido contrato psicológico establecido a través de este proceso de autorregulación desarrollado tras la violación estará en función del grado en que se ha resuelto la violación, lo cual da lugar a cuatro posibles tipos de contratos psicológicos posteriores a la violación. Una resolución exitosa se traducirá en una reactivación del contrato psicológico o en uno que florece o prospera a partir de una redefinición de su contenido. Por el contrario, una pobre resolución de la violación dará lugar a un contrato psicológico deteriorado o uno en disolución. Cuando no se logra un nuevo contrato psicológico funcional (contrato deteriorado), la víctima asume las pérdidas producidas o cambia el tipo de contrato; así, por ejemplo, cuando el trabajador tenía un contrato psicológico de carácter más relacional (socioemocional) que tras la violación se convierte en un contrato transaccional (instrumental o material). En el caso de que ni siquiera se logre mantener un contrato psicológico mínimo, la relación iniciará una fase de disolución que probablemente termine en una ruptura del contrato laboral (Tomprou, Hansen \& Rousseau, 2015).

Como se puede apreciar, el modelo posviolación supone una valiosa aportación al conocimiento del desarrollo del contrato psicológico tras las experiencias de ruptura y violación, experiencias que constituyen más la norma que la excepción en las relaciones laborales (Robinson \& Rousseau, 1994), y subrayan el carácter temporal y dinámico del constructo. No obstante, a pesar de su valor heurístico, es preciso señalar que se mantiene dentro de la perspectiva tradicional de la supuesta relación bilateral entre el empleado y la organización, por lo que la teoría y las investigación futuras deberán tratar de incorporar la complejidad de la agencia múltiple, y considerar la multiplicidad de estados (es decir, la combinación de cumplimientos parciales y rupturas/violaciones parciales que se producen simultánea y consecutivamente) del contrato psicológico con cada uno de los agentes o stakeholders implicados.

El modelo más reciente que trata de integrar y avanzar en la comprensión del carácter temporal del contrato psicológico es el formulado por estas mismas autoras (Rousseau, Hansen \& Tomprou, 2018), denominado modelo de fases dinámicas. En síntesis, plantea que los procesos implicados en el contrato psicológico pasan por cuatro fases (con dinámicas intrafase e interfases), denominadas creación, mantenimiento, renegociación y reparación, en las que las funciones de variables como 
las promesas, los incentivos, las contribuciones y las obligaciones cambian con el tiempo y con el contexto de la relación laboral. Cuando un empleado se incorpora a una organización, se inicia la fase de creación del contrato psicológico, durante la cual predominan las creencias basadas en las expectativas del empleado acerca de lo que espera en la relación laboral y las expectativas de la organización acerca de las contribuciones que espera de él o ella; estas expectativas, que son básicamente normativas (lo que es razonable esperar en una relación laboral), generan la percepción de obligaciones. Además, en esta fase tienen importancia las promesas transmitidas, puesto que es fundamentalmente al inicio cuando el empleador, a través de los diferentes agentes organizacionales, establece lo que el empleado va a lograr o puede obtener a cambio de sus actitudes, su comportamiento y su rendimiento en el trabajo. Así, el modelo integra los elementos, señalados al comienzo del capítulo, que habían generado las discrepancias acerca del contenido del contrato psicológico (Conway \& Pekcan, 2019; Hansen, 2019): las expectativas y las promesas, generadas básicamente en la fase de creación del contrato psicológico, se convierten en obligaciones en las fases siguientes, obligaciones que se articulan como los puntos de referencia que sirven para que las partes evalúen el grado de cumplimiento/incumplimiento del contrato psicológico (Rousseau, Hansen \& Tomprou, 2018).

La segunda fase se denomina de mantenimiento, y constituye el marco relativamente estable que pauta las relaciones del empleado con la organización, como los incentivos que puede obtener (oportunidades de desarrollo y promoción, formación, beneficios y recompensas, apoyo organizacional) a cambio de sus conductas de rol (las implicadas en sus tareas para el logro de un rendimiento eficaz) y sus conductas extra rol (conductas de ciudadanía organizacional). Esta fase puede durar semanas, meses o más, dependiendo del carácter y de la estabilidad de la relación laboral, la cual se mantiene salvo que el empleado perciba una disrupción (típicamente, la percepción de ruptura del contrato psicológico) o hasta que decide abandonar la organización, decisión que puede estar motivada por factores negativos (falta de ajuste, insatisfacción, etc.) o no (por ejemplo, al haber recibido una oferta de trabajo más valorada) (Rousseau, Hansen \& Tomprou (2018). Como ya se señaló, la ruptura del contrato psicológico es el resultado de la percepción de una discrepancia negativa entre las obligaciones esperadas y la conducta real del empleador, pero las autoras proponen ampliar la conceptualización del contrato psicológico mediante el término disrupción, para referirse al evento afectivo asociado con una discrepancia, positiva o negativa, percibida por el empleador entre el contenido del contrato psicológico y las experiencias reales. Lo importante en el modelo es la valencia de la respuesta emocional provocada por la disrupción, valencia que indica si esta se considera positiva o negativa. Mientras que los incumplimientos del contrato psicológico por el 
empleador (es decir, una disrupción que representa una discrepancia negativa) generan un afecto negativo en el empleado, los sobrecumplientos del contrato psicológico (esto es, una disrupción que supone una discrepancia positiva al recibir más de lo que se esperaba) pueden generar respuestas afectivas tanto positivas como negativas (Rousseau, Hansen \& Tomprou, 2018). Si durante la fase de mantenimiento no se producen disrupciones, el contrato psicológico permanece estable en el sentido ya indicado, caracterizado por intercambios donde ambas partes cumplen con sus obligaciones y predomina una orientación relacional (Alcover, Martínez-Íñigo \& Chambel, 2012). Pero si se producen disrupciones, positivas o negativas, se pasa a la tercera o cuarta fase, alternativamente.

La fase de renegociación se produce cuando se experimenta una respuesta afectiva positiva por un cumplimiento del contrato psicológico que excede en diferente grado el contenido esperado. Este estado conduce a las partes a renegociar el contrato psicológico "ampliado", que puede incluir acuerdos individuales o $i$-deals, o también puede provocar solo un cambio intraindividual, en el sentido en que el empleado modifica unilateralmente su esquema cognitivo del contrato psicológico para integrar los cambios producidos por los incentivos no esperados. En ambos casos, sobre todo cuando la renegociación es interpersonal, se produce una respuesta emocional positiva que inicia la transición a una nueva fase de mantenimiento del contrato psicológico. Por su parte, cuando la disrupción ha sido negativa (tanto por un incumplimiento como por un sobrecumplimiento), se inicia la fase de reparación, caracterizada por la motivación del empleado a reducir el afecto negativo y a restablecer un contrato psicológico funcional que permita al menos el mantenimiento de la relación. Esto puede lograrse revisando, en su totalidad o en parte, el contenido del contrato psicológico, y ajustando las obligaciones del empleado o del empleador, con el objetivo de reducir las discrepancias percibidas y el afecto negativo que generan, de modo similar a como planteaba el modelo posviolación ya analizado (Tomprou, Hansen \& Rousseau, 2015). Dicho afecto negativo, no obstante, va a mediar la reparación del contrato psicológico, en el sentido en que el malestar, la desconfianza o el resentimiento del empleado generados por la disrupción condicionan su percepción y su valoración de las promesas del empleador y de las nuevas obligaciones acordadas. Si el contrato psicológico logra repararse, se inicia la transición a una nueva fase de mantenimiento, pero si el afecto negativo es muy intenso debido a que el empleado percibe que la disrupción ha sido intolerable y no se logra la reparación, la decisión será el abandono de la relación laboral (Rousseau, Hansen \& Tomprou, 2018). En suma, el modelo ofrece un marco de comprensión, explicación y predicción acerca de la naturaleza dinámica de los contratos psicológicos, y representa una integración temporal de procesos hasta ahora analizados transversalmente por la investigación tradicional. 
La investigación futura sobre los procesos temporales y dinámicos constituirá sin duda uno de los campos más relevantes en el análisis de los contratos psicológicos (Griep, Cooper, Robinson, Rousseau, Hansen, Tomprou et ál., 2019; Kraak \& Linde, 2019), y tiene ante sí el desafío de integrar los elementos considerados en la perspectiva de la agencia múltiple ya analizada en este capítulo. También será relevante el análisis del tiempo en los procesos posviolación y las estrategias utilizadas por los trabajadores (Coyle-Shapiro et ál., 2019; Schalk, De Ruiter, Van Loon, Kuijpers \& Van Regenmortel, 2018), puesto que es de gran importancia analizar cuánto tiempo es necesario para la recuperación del contrato psicológico (ya sea mediante una negociación o a través de una reparación; Rousseau, Hansen \& Tomprou, 2018), conocer qué variables individuales pueden influir en dicho proceso - por ejemplo, tendencia a confiar como rasgo personal, extraversión, neuroticismo, autoestima, etc. (Raja, Johns \& Ntalianis, 2004), así como la resiliencia, autoeficacia, optimismo y esperanza, es decir, el denominado capital psicológico (Luthans \& Youssef-Morgan, 2017) - y qué estrategias organizacionales pueden ser más eficaces y rápidas en la recuperación de los contratos psicológicos (Coyle-Shapiro et ál., 2019). Por todo ello, el tiempo será una de las dimensiones inexcusables en los modelos teóricos que guíen la investigación futura (Griep, Cooper, Robinson, Rousseau, Hansen, Tomprou et ál., 2019; Kraak \& Linde, 2019).

\section{Acuerdo idiosincrásico (I-deals) en las nuevas relaciones laborales}

Como ya se mencionó, las transformaciones geo-socio-políticas, económicas y empresariales de las últimas décadas han propiciado la expansión de la ideología neoliberal, que ha transformado, entre otros muchos ámbitos públicos y privados, el mundo del trabajo y las relaciones laborales. Como señalan Bal y Dóci (2018), el neoliberalismo tiene múltiples efectos. En primer lugar, la desregulación, la privatización y la retirada de los poderes públicos de las disposiciones y marcos sociales han traído consigo que el poder se encuentre no tanto en los gobiernos como en las grandes corporaciones, generalmente multinacionales sin cara. Así, la competición y la lógica de mercado como únicos mecanismos válidos en las organizaciones dirige a estas hacia la maximización de los beneficios, creando una simple dicotomía entre los ganadores (que no solo sobreviven, sino que tiende a aumentar su actividad y su poder, como puede verse con la creciente diversificación de las grandes multinacionales) y los perdedores, incapaces de mantenerse en un mercado libre que no perdona los errores. En segundo lugar, como consecuencia de esta lógica, un pequeño número de empresas y de personas (que no obstante, a veces no se conocen, ya que dirigen desde un intencionado anonimato) concentran un poder cada vez mayor al acaparar mayores cuotas del mercado global. A su vez, este escenario produce una 
distancia abismal entre las todopoderosas empresas y los individuos, lo que genera una creciente desigualdad, ya que la capacidad de un trabajador para negociar sus condiciones laborales en este tipo de relaciones es muy reducida, y la negociación colectiva ha perdido protagonismo en un mundo globalizado donde los sindicatos, tanto los de clase como los profesionales, han visto perder sus niveles de afiliación y su poder real de ejercer presión. Por último, dado que el mercado privilegia a los más fuertes y la regulación y protección de los gobiernos tiende a debilitarse (facilidad para el despido, prevalencia de contratos temporales, disminución de prestaciones sanitarias, por desempleo y por dependencia), las personas más vulnerables son las que con más probabilidad sufren las consecuencias de esta desprotección y se ven abocadas a una autosuficiencia precaria (Bal \& Dóci, 2018). La segmentación, por lo tanto, cada vez es más acusada, ya que no solamente las personas desempleadas se encuentran en el límite de la supervivencia, sino que también un número creciente de trabajadores apenas subsisten con salarios mínimos y condiciones de empleo precarizadas, frente a un número relativamente reducido en proporción de trabajadores de élite (y propietarios de empresas) cuyos salarios y condiciones de trabajo hacen que un porcentaje cada vez mayor de la riqueza se concentre en un segmento cada vez más reducido de individuos.

La combinación del creciente individualismo como valor cultural (tanto en las sociedades industrializadas como en los países en desarrollo) y de la ideología neoliberal tiene como consecuencia el énfasis en la naturaleza contractual de los intercambios, que se consideran básicamente transaccionales, en detrimento de la orientación relacional de los intercambios sociales entre los empleados y la organización (Bal \& Hornung, 2019; Culinane \& Dundon, 2006). Este desplazamiento de lo relacional a lo transaccional ha tenido su efecto también en la propia conceptualización de los contratos psicológicos y otros constructos asociados, como se analiza a continuación.

Según Bal y Dóci (2018), la ideología neoliberal no solo afecta al mundo del trabajo y a las prácticas laborales, sino que también influye en la propia orientación adoptada por la psicología del trabajo y de las organizaciones (PTO) en su investigación y su práctica. Si bien no hay espacio aquí para un análisis de este relevante fenómeno, sí se ha querido incluir esta breve acotación para introducir el último de los ejes señalados en este capítulo sobre el presente y el futuro del contrato psicológico, ya que refleja con nitidez la dirección de la ideología neoliberal mencionada en ambos planos, el mercado y la PTO, así como la individualización del trabajo (Bal \& Hornung, 2019; Bal \& Lub, 2015). Se trata del término acuerdos idiosincrásicos (i-deals), que según Rousseau, Ho y Greenberg (2006), se definen formalmente como 
los acuerdos voluntarios y personalizados de naturaleza no estándar negociados entre empleados individuales y sus empleadores con respecto a los términos que benefician a cada parte. Estos acuerdos de empleo individualizados difieren, en cierta medida, de los de los compañeros de trabajo de los empleados. (p. 978)

Los autores especifican que, pese a ser acuerdos individuales que diferencian entre sí a los propios compañeros de un equipo o un departamento, no hay que considerarlos como el resultado de amiguismo o favoritismo entre el beneficiario y los agentes organizacionales entre los que se negocia. Por supuesto, tampoco se refieren a posibles acuerdos ilegales o irregulares que impliquen un incumplimiento de reglas y normas laborales. Los acuerdos idiosincrásicos pueden negociarse antes de la contratación (denominado ex ante i-deal) o una vez iniciada (ex post i-deal). Sus principales características, en consecuencia, son: 1) se trata de acuerdos individuales entre el empleado y su empleador actual o futuro, y diferentes en su contenido a los de sus compañeros de trabajo; 2) son heterogéneos en su contenido, y pueden incluir una gran cantidad de incentivos y recompensas, tanto formales como informales, a cambio de las contribuciones variadas del empleado; 3) son acuerdos laborales que benefician los intereses de ambas partes, puesto que, como señalan Rousseau, Ho y Greenberg (2006), "el resultado exitoso de un i-deal es que una organización atrae, motiva o retiene los servicios de un empleado valioso quien, a su vez, recibe los recursos deseados de esa organización" (p.978); y 4) son variados en cuanto al volumen de su contenido, ya que pueden referirse a la negociación de un único elemento del contrato (por ejemplo, el salario o la flexibilidad) o a un amplio paquete de incentivos y contribuciones que incluya la totalidad de los componentes importantes de la relación laboral. En todos los casos, es fundamental tener en cuenta que en los acuerdos idiosincrásicos los empleados participan activamente (es decir, tienen el poder de negociar) en la definición, en parte o en su totalidad, de los términos del contrato de trabajo (Rousseau, Ho \& Greenberg, 2006). De algún modo, se refieren a situaciones de relativa simetría de poder entre las partes, o al menos de apariencia de simetría en la negociación.

El contenido de los acuerdos idiosincrásicos puede formar parte del contrato psicológico del empleado (Rousseau, Ho \& Greenberg, 2006) junto a características que también comparte con los contenidos de los contratos de los compañeros de trabajo (Rousseau, 1995). Una modalidad de contrato psicológico denominado balanceado (según la clasificación de Rousseau, 1995), que combina elementos tanto relacionales como transaccionales, y que se caracteriza fundamentalmente por incluir creencias acerca de su capacidad para ser renegociado con frecuencia en función de los intereses y necesidades de la organización y del empleado, favorece la búsqueda de acuerdos idiosincrásicos que faciliten la carrera profesional y potencien la empleabilidad 
(Rousseau, 2005). También se ha encontrado que en épocas de austeridad organizacional (es decir, situaciones de restricciones y ajustes económicos como las originadas desde la crisis financiera global de 2007-2008) los $i$-deals pueden utilizarse para aceptar nuevos contratos psicológicos, puesto que al negociarse explícitamente los términos, proporcionan cierta seguridad a los empleados acerca de su situación laboral y contribuyen a mantener el compromiso en momentos de austeridad (Davies \& Van der Heijden, 2018). Los resultados de la investigación muestran que los ámbitos que se negocian habitualmente en los ex post $i$-deals son la flexibilidad de horarios, la flexibilidad de ubicación, las tareas y responsabilidades laborales y los incentivos financieros (Rosen, Slater, Chang \& Johnson, 2013), así como las oportunidades de desarrollo profesional (Hornung, Rousseau \& Glaser, 2009). En general, entre los antecedentes más relevantes para negociar acuerdos idiosincrásicos se encuentran la prevalencia de valores culturales individualistas, las características del trabajo (limitaciones laborales, alternativas de empleo y nivel profesional), características del líder o agente organizacional (personalidad, conductas y estilo de liderazgo) y las características del empleado (proactividad, habilidades sociales, iniciativa, inteligencia emocional y características sociodemográficas) (Liao, Wayne \& Rousseau, 2016). En particular, en los ex post i-deals los antecedentes fundamentales son la mayor antigüedad en la organización, contar con habilidades políticas y la existencia de relaciones líder-miembros de calidad (Rosen et ál., 2013). Y en cuanto a las consecuencias, el éxito de los acuerdos idiosincrásicos tiene implicaciones importantes para la motivación, el rendimiento de tarea y el contextual (conductas de ciudadanía organizacional), la intención de abandono, el conflicto trabajo-familia, el engagement, las conductas de voz y la creatividad (Hornung, Rousseau \& Glaser, 2009; Liao, Wayne \& Rousseau, 2016), así como para las actitudes laborales, especialmente en relación con la satisfacción laboral y el compromiso organizacional (Liao, Wayne \& Rousseau, 2016; Rosen et ál., 2013; Vidyarthi, Chaudhry Anand \& Liden, 2014); en este último caso, cuando el $i$-deal tenga un componente más relacional-social que transaccional-económico, su relación es más fuerte con las dimensiones afectiva y normativa del compromiso organizacional (Rosen et ál., 2013).

Uno de los aspectos más controvertidos y discutidos en el ámbito académico es el relativo a las diferencias y las similitudes entre los acuerdos idiosincrásicos y los contratos psicológicos. Según Rousseau, la investigadora que ha liderado la investigación tanto sobre el contrato psicológico (p. ej., Rousseau, 1989, 1995) como acerca de los i-deals (p. ej., Rousseau, 2005 y sus colegas Hornung \& Rousseau, 2017; Liao, Wayne \& Rousseau, 2016), las diferencias entre ambos constructos se pueden establecer a partir de tres dimensiones básicas. 
En primer lugar, mientras que el primero se basa en percepciones del empleado que reflejan las creencias subjetivas acerca de las promesas del empleador en relación a los términos que definen la relación laboral (Rousseau, 1995; Zhao et ál., 2007), los segundos no son inherentemente perceptuales, sino que se refieren a las condiciones de trabajo reales que un empleado ha logrado negociar con un empleador (Liao, Wayne \& Rousseau, 2016). De esta distinción parece deducirse que los acuerdos idiosincrásicos poseen un carácter explícito, objetivo, a diferencia de la naturaleza básicamente implícita y subjetiva de los contratos psicológicos. En consecuencia, los acuerdos idiosincrásicos pueden contribuir al desarrollo de contratos psicológicos diferentes (Liao, Wayne \& Rousseau, 2016; Rousseau, 2005). Además, las autoras consideran que un empleado puede estar motivado para lograr la negociación de un $i$-deal a partir del contrato psicológico, en el sentido en que puede percibir que sus contribuciones de calidad le dotan de credenciales para recibir por parte de la organización unas recompensas acordes a su esfuerzo y a sus logros (Rousseau, 2005). En segundo lugar, como consecuencia de lo anterior, los contratos psicológicos son inherentemente intraindividuales, mientras que los $i$-deals son en esencia interpersonales. Y, por último, mientras que los primeros se basan en la justicia percibida por el empleado acerca de los términos incluidos en la relación laboral, los segundos se fundamentan en la justicia social y procedimental (Ho \& Tekleab, 2016; Hornung \& Rousseau, 2017). En conclusión, los contratos psicológicos y los acuerdos idiosincrásicos son constructos que reflejan fenómenos relacionados, pero diferentes en esencia (Liao, Wayne \& Rousseau, 2016), puesto que "las creencias subjetivas con respecto a las obligaciones mutuas en la relación de intercambio con la organización y las condiciones de empleo personalizadas obtenidas objetivamente son fenómenos interrelacionados pero distintos" (Bal \& Hornung, 2019, p. 144). El debate y la discusión acerca de las razones que explican el tránsito en la investigación desde el contrato psicológico hacia el acuerdo idiosincrásico, así como su tensa convivencia en la academia, se encuentra en plena efervescencia (p. ej., Bal \& Hornung, 2019; Conway \& Coyle-Shapiro, 2016; Conway \& Pekcan, 2019; Hornung \& Rousseau, 2017), pero no resulta posible aquí un análisis detallado, por lo que se remite al lector interesado a la literatura citada.

En síntesis, los principales investigadores en este ámbito (Bal \& Hornung, 2019; Hornung \& Rousseau, 2017) destacan que, si bien ambos constructos son un reflejo del carácter de las relaciones laborales en la actualidad, es preciso que la investigación en PTO avance más allá y no se asuman acríticamente los planteamientos impuestos por la ideología neoliberal (Bal \& Dóci, 2018) acerca de lo que normativamente han de ser las relaciones entre empleados y empleadores. La ausencia de una reflexión crítica acerca de los supuestos que subyacen en las teorías y modelos que orientan la 
investigación puede representarse en este caso mediante una asunción que, conscientemente o no, caracteriza el análisis (Bal \& Hornung, 2019) marcado por el "nuevo unitarismo" (Greenwood \& Van Buren III, 2017), es decir, marcos de referencia que conciben las relaciones laborales y los lugares de trabajo regidos por intereses compartidos entre los empleados y los empleadores y una única fuente de autoridad. Esta ideología unitaria se refleja en el denominado "mito de la congruencia de metas" (Greenwood \& Van Buren III, 2017), que asume implícitamente que ambas partes tienen intereses similares, que las diferencias de poder entre ellas no son relevantes y que pueden satisfacerse los intereses, las necesidades y los intereses mutuos simultáneamente gracias a los acuerdos, la coordinación y el ajuste a las condiciones reales, diseñando una relación laboral perfecta guiada por el beneficio mutuo. Sin embargo, buena parte de las realidades laborales no parece que puedan describirse en estos términos. Por ello, es necesario plantear alternativas pluralistas a este paradigma unitario (Bal \& Hornung, 2019; Greenwood \& Van Buren III, 2017) que reflejen la complejidad de las relaciones entre los individuos y las organizaciones.

Un ejemplo de la alternativa pluralista lo constituye el enfoque denominado dignidad en el trabajo (Bal, 2017; Bal \& De Jong, 2017), cuyo enfoque puede resumirse del siguiente modo:

\footnotetext{
El paradigma de la dignidad constituye una alternativa a la lógica instrumental del capitalismo neoliberal y postula el valor intrínseco e inherente del lugar de trabajo y, por lo tanto, la posición de los individuos dentro de las organizaciones y los lugares de trabajo. En línea con el argumento kantiano de que las personas nunca deberían ser tratadas como un medio para el logro de un fin, sino siempre como un fin en sí mismas, el paradigma de la dignidad postula que, en el lugar de trabajo, las personas (y en extensión cualquier objeto material o inmaterial) no pueden ser simplemente tratados como un medio. (Bal \& Hornung, 2019, p. 158)
}

En concreto, este enfoque puede permitir una aproximación diferente al contrato psicológico, ya que evitaría la asunción de que se trata de la percepción del empleado acerca de un contenido que ha sido en gran medida impuesto por el empleador en una relación instrumental y aceptado de forma más o menos pasiva por aquél. Un enfoque basado en la dignidad obligaría a asumir que el empleado, al tener valor como persona y ser un fin en sí mismo, ha de asumir un papel activo en la creación y desarrollo del contrato psicológico, de modo que se reflejará en él el significado intrínseco del trabajo, no solo para las dos partes, sino también para los compañeros de trabajo y todos los miembros de la organización, ampliándose a la comunidad y a la sociedad como un todo. En suma, se trata de abandonar la lógica instrumental del trabajo y recuperar el valor y la dignidad de la persona y de la actividad laboral en sí misma, 
así como el sentido de pertenecer a un grupo, a un colectivo, a una comunidad y reducir con ello el generalizado individualismo característico de los contextos sociales actuales (Bal, 2017; Bal \& Hornung, 2019). También este enfoque de la dignidad puede ser útil en la redefinición de los acuerdos idiosincrásicos, puesto que cuando se plantea una negociación en estos términos no debería solamente tenerse en cuenta la justicia implícita en cada relación particular empleado-empleador, sino en la justicia y la distribución de recursos, oportunidades y condiciones de trabajo de todos los miembros de la organización, de modo que los acuerdos trasciendan las relaciones particulares y contribuyan a la emancipación de las condiciones que limitan la dignidad, el desarrollo personal y la autorrealización (Bal \& Hornung, 2019). Sin duda, la investigación futura en este ámbito no solo debe limitarse a la necesaria clarificación conceptual y metodológica del constructo i-deal (Conway \& Coyle-Shapiro, 2016; Hornung \& Rousseau, 2017), sino también dirigirse hacia una mejora de la actividad laboral, las condiciones de trabajo, las relaciones laborales y la vida social en las organizaciones, y devolver al individuo el valor y la dignidad que le corresponden en la imprescindible organización productiva de las sociedades, la búsqueda de una mejor calidad de vida, como Bal y sus colegas (Bal, 2017; Bal \& De Jong, 2017; Bal \& Hornung, 2019) postulan.

\section{Conclusiones}

A pesar de la abundante teorización e investigación sobre los contratos psicológicos, no se han resuelto satisfactoriamente (al menos para una parte significativa de investigadores) algunas de las ambigüedades centrales del constructo (Conway \& Briner, 2005; Culinane \& Dundon, 2006; Kraak \& Linde, 2019; Hansen, 2019), como el grado en que su contenido es implícito, las características de la interacción entre las "dos partes", la naturaleza real de los intercambios (reciprocidad, mutualidad, nivel de asimetría), el grado de subjetividad y realidad en la percepción de los incumplimientos y las rupturas o cómo deberían ser gestionados, lo que obliga a una continua reflexión y profundización es estos elementos con objeto de avanzar en la investigación sobre estas complejas, implícitas e intersubjetivas relaciones entre múltiples partes (Conway \& Pekcan, 2019; Griep, Cooper, Robinson, Rousseau, Hansen, Tomprou et ál., 2019). En particular, Conway y Pekcan (2019) destacan que, a pesar de la vitalidad de la investigación en las tres últimas décadas, su foco se ha ido desplazando progresivamente hacia el contenido (promesas) explícito del contrato psicológico. Esto ha desvirtuado en cierto modo el carácter del constructo tal y como se reformuló por Rousseau (1989), por lo que recomiendan volver a los elementos originales que se han descuidado con el paso del tiempo, como su carácter implícito, la relación entre dos partes (aunque no hay que olvidar la inclusión del enfoque de la agencia múltiple 
de la organización) y su relación con la salud mental positiva del empleado (Conway \& Pekcan, 2019).

Otro proceso emergente que recibirá atención en los próximos años es el relativo al contrato psicológico establecido entre los miembros en los equipos de trabajo (Akkermans, de Jong, S., de Jong, J. \& Bal, 2019; Alcover, Rico, Turnley \& Bolino, 2017c), referido a cómo las dinámicas de las relaciones, la percepción de justicia entre pares, el apoyo percibido de los compañeros y las relaciones líder-miembros pueden contribuir a la creación y desarrollo de los contratos psicológicos en un contexto colectivo (Alcover et ál., 2017c). Teniendo en cuenta la creciente utilización de los equipos de trabajo en todo tipo de tareas, contextos y organizaciones, la investigación sobre el contrato psicológico en estos sistemas socio-técnicos asumirá un mayor protagonismo en los próximos años.

Por último, la reciente revisión de Coyle-Shapiro et ál. (2019) destaca los cinco ámbitos prioritarios de la investigación futura sobre el contrato psicológico. En primer lugar, el análisis de los tipos de recursos intercambiados, especialmente los relativos al contenido ideológico, tanto por parte del empleado como especialmente de la organización, cuyo carácter puede variar en función de las organizaciones, las profesiones y los contextos culturales y tener efectos diferenciales en las reacciones a los incumplimientos y las violaciones. En segundo lugar, el estudio de los efectos sobre la salud física y mental de los empleados como resultado de los contratos psicológicos, en qué modo su cumplimiento contribuye a su bienestar o su violación constituir un estresor con respuestas disfuncionales para la salud. Tercero, investigar con más profundidad el papel desempeñado por las necesidades psicológicas en la formación y el desarrollo del contrato, así como su consideración como un marco explicativo central que vincula los contratos psicológicos con los resultados obtenidos. En cuarto lugar, la mayor atención a enfoques policontextuales, es decir, la consideración de los factores macroeconómicos, culturales y sociales en la configuración y características de los contratos psicológicos y el papel desempeñado por ellos en las percepciones de cumplimiento o ruptura y violación, así como en las reacciones a ellas y las consecuencias que pueden tener para los trabajadores y para las organizaciones. Este ámbito resulta de vital importancia precisamente por lo que este libro sobre el contrato psicológico en las Américas ha tratado de poner de manifiesto: la necesidad de contextualizar la investigación en el marco de las características sociales, económicas, culturales, políticas e históricas de cada país, y comprender desde ellas tanto las condiciones en las que se desenvuelven las actividades laborales como las subjetividades que interpretan y otorgan significado a las experiencias de trabajo. Por último, y como ya se ha tratado con más detalle en este capítulo, el análisis de la ruptura/violación y las reacciones posteriores a ellas, así como sus implicaciones para la futura 
relación empleado-organización. Por su parte, un nutrido grupo compuesto por los principales investigadores e investigadoras en este ámbito (Griep, Cooper, Robinson, Rousseau, Hansen, Tomprou et ál., 2019) concluye que las tres áreas clave que enriquecerán el futuro de la investigación sobre el contrato psicológico se articulan en el análisis del tiempo, el contexto social y la naturaleza cambiante del trabajo.

En definitiva, los investigadores en este campo subrayan tanto la vitalidad de los contratos psicológicos y los constructos asociados como la necesidad de identificar los problemas que permanecen sin resolver, así como los retos a los que se enfrenta la redefinición del contrato psicológico en un mundo del trabajo en cambio permanente y acelerado que obliga a una continua reconfiguración de los conceptos, las metodologías y los instrumentos de medida. Puede parecer que treinta años no son nada, pero entre 1989 y 2019 el mundo, las relaciones laborales, las organizaciones e instituciones y los valores, expectativas, actitudes y comportamientos de las personas se han transformado radicalmente. La teoría y la investigación en PTO no pueden ignorar este dinamismo, y solo una perspectiva próxima, comprometida y crítica con las realidades y sus subjetividades (interpretaciones y sentidos) puede dar cuenta de los fenómenos psicológicos, psicosociales, organizacionales y sociales a los que trata de comprender, explicar y mejorar con sus intervenciones.

\section{Referencias}

Aggarwal, U. \& Bhargava, S. (2009). Reviewing the relationship between human resource practices and psychological contract and their impact on employee attitude and behaviours: A conceptual model. Journal of European Industrial Training, 33, 4-31.

Akkermans, J., de Jong, S., de Jong, J. \& Bal, P. M. (2019). Me and my team: the role of social context in psychological contract breach and fulfilment. En: Y. Griep \& C. Cooper (eds.). Handbook of research on the psychological contract at work (pp. 164-185). Edward Elgar.

Alcover, C. M. (2002). El contrato psicológico. El componente implícito de las relaciones laborales. Ediciones Aljibe.

Alcover, C. M., Martínez-Î́nigo, D. \& Chambel, M. J. (2012). Perceptions of employment relations and permanence in the organization: Mediating effects of affective commitment in relations of psychological contract and intention to quit. Psychological Reports, 110, 839-853.

Alcover, C. M., Rico, R., Turnley, W. H. \& Bolino, M. C. (2017a). Understanding the changing nature of psychological contracts in 21st century organizations: A multiple-foci exchange relationships approach and proposed framework. Organizational Psychology Review, 7, 4-35. 
Alcover, C. M., Rico, R., Turnley, W. H. \& Bolino, M. C. (2017b). Multi-dependence in the formation and development of the distributed psychological contract, European Journal of Work and Organizational Psychology, 26, 16-29.

Alcover, C. M., Rico, R., Turnley, W. H. \& Bolino, M. C. (2017c). Psychological contract in teams. En: E. Salas, R. Rico \& J. Passmore (eds.). The wiley blackwell handbook of the psychology of team working and collaborative processes (pp. 417-440). Wiley.

Andersson, L. M. (1996). Employee cynicism: An examination using a contract violation framework. Human Relations, 49, 1395-1418.

Argyris, C. (1960). Understanding Organizational Behavior. Tavistock.

Arnold, J. (1996). The psychological contract: A concept in need of closer scrutiny? European Journal of Work and Organizational Psychology, 5, 511-520.

Bal, P. M. (2017). Dignity in the workplace. new theoretical perspectives. Palgrave MacMillan.

Bal, P. M. \& De Jong, S. B. (2017). From human resource management to human dignity development: a dignity perspective on HRM and the role of workplace democracy. En: M. Kostera \& M. Pirson (eds.). Dignity and organizations (pp. 173-195). Palgrave McMillan.

Bal, P. M., De Lange, A. H., Jansen, P. G. \& Van Der Velde, M. E. (2008). Psychological contract breach and job attitudes: A meta-analysis of age as a moderator. Journal of Vocational Behavior, 72, 143-158.

Bal, P. M. \& Dóci, E. (2018). Neoliberal ideology in work and organizational psychology, European Journal of Work and Organizational Psychology, 27, 536-548.

Bal, P. M. \& Hornung, S. (2019). Individualization of work: from psychological contracts to ideological deals. En Y. Griep \& C. Cooper (eds.). Handbook of research on the psychological contract at work (pp. 143-163). Edward Elgar.

Bal, P. M. y Lub, X. D. (2015). Individualization of work arrangements: A contextualized perspective on the rise and use of i-deals. En P. M. Bal y D. M. Rousseau (eds.), Idiosyncratic Deals between Employees and Organizations: Conceptual Issues, Applications, and the Role of Coworkers (pp. 9-23). Psychology Press.

Bankins, S. (2015). A process perspective on psychological contract change: Making sense of, and repairing, psychological contract breach and violation through employee coping actions. Journal of Organizational Behavior, 36, 1071-1095.

Baruch, Y. \& Rousseau, D. M. (2019). Integrating psychological contracts and ecosystems in career studies and management. Academy of Management Annals, 13, 84-111.

Bordia, P., Restubog, S. L. D. \& Tang, R. L. (2008). When employees strike back: Investigating mediating mechanisms between psychological contract breach and workplace deviance. Journal of Applied Psychology, 93, 1104-1117.

Bordia, P., Restubog, S. L. D., Bordia, S. \& Tang, R. L. (2010). Breach begets breach: Trickle-down effects of psychological contract breach on customer service. Journal of Management, 36, 1578-1607. 
Carver, C. \& Scheier, M. F. (1994). Situational coping and coping dispositions in a stressful transaction. Journal of Personality and Social Psychology, 66, 184-184.

Chambel, M. J. \& Alcover, C. M. (2011). The psychological contract of call-centre workers: employment conditions, satisfaction and civic virtue behaviours. Economic and Industrial Democracy, 32, 115-134.

Chaudhry, A., Wayne, S. J. \& Schalk, R. (2009) A sensemaking model of employee evaluation of psychological contract fulfillment: when and how do employees respond to change? Journal of Applied Behavioral Science, 45, 498-520.

Conway, N. \& Briner, R. B. (2005). Understanding psychological contracts at work. a critical evaluation of theory and research. Oxford University Press.

Conway, N. \& Briner, R. B. (2009). Fifty years of psychological contract research: what do we know and what are the main challenges. En: G. P. Hodgkinson \& J. K. Ford (eds.). International review of industrial and organizational psychology (pp. 71-131). Wiley-Blackwell.

Conway, N. \& Coyle-Shapiro, J. (2016). Not so i-deal: a critical review of idiosyncratic-deals theory and research. En: M. Bal \& D. M. Rousseau (eds.). Idiosyncratic deals between employees and organizations: conceptual issues, applications and the role of co-workers. current issues in work and organizational psychology (pp. 36-64). Routledge.

Conway, N. \& Pekcan, C. (2019). Psychological contract research: older, but is it wiser? En: Y. Griep \& C. Cooper (eds.). Handbook of research on the psychological contract at work (pp. 10-34). Edward Elgar.

Coyle-Shapiro, J. A-M. (2002). A psychological contract perspective on organizational citizenship behavior. Journal of Organizational Behavior, 23, 927-946.

Coyle-Shapiro, J. A.-M., Costa, S. P., Doden, W. \& Chang, C. (2019). Psychological contracts: past, present, and future. Annual Review of Organizational Psychology and Organizational Behavior, 6, 1-25.

Coyle-Shapiro, J. A.-M. \& Parzefall, M. (2008). Psychological contracts. En: C. L. Cooper \& J. Barling (eds.). The SAGE handbook of organizational behavior (pp. 17-34). Sage.

Coyle-Shapiro, J. A-M. \& Shore, L. M. (2007). The employee-organization relationship: Where do we go from here? Human Resource Management Review, 17, 166- 179.

Cullinane, N. \& Dundon, T. (2006). The psychological contract: a critical review. International Journal of Management Reviews, 8, 113-129.

D'Art, D. \& Turner, T. (2006) New working arrangements: changing the nature of the employment relationship? The International Journal of Human Resource Management, 17, 523-538.

Dabos, G. E. \& Rousseau, D. M. (2004). Mutuality and reciprocity in the psychological contracts of employees and employers. Journal of Applied Psychology, 89, 52-72.

Davies, A. S. \& Van der Heijden, B. I. J. M. (2018). Reciprocity matters: idiosyncratic deals to shape the psychological contract and foster employee engagement in times of austerity. Human Resource Development Quarterly, 29, 329-355. 
Dawson, G. S., Karahanna, E. \& Buchholtz, A. (2014). A study of psychological contract breach spillover in multiple-agency relationships in consulting professional service firms. Organization Science, 25, 149-170.

Delobbe, N., Cooper-Thomas, H. D. \& De Hoe, R. (2016). A new look at the psycho- logical contract during organizational socialization: the role of newcomers' obligations at entry. Journal of Organizational Behavior, 37, 845-867.

Dulac, T., Coyle-Shapiro, J. A-M., Henderson, D. J. \& Wayne, S. J. (2008). Not all responses to breach are the same: the interconnection of social exchange and psychological contract processes in organizations. Academy of Management Journal, 51, 1079-1098.

Eisenberger, R., Armeli, S., Rexwinkel, B., Lynch, P. D. \& Rhoades, L. (2001). Reciprocation of perceived organizational support. Journal of Applied Psychology, 86, 42-51.

Greenwood, M. \& Van Buren III, H. J. (2017). Ideology in HRM Scholarship: Interrogating the Ideological Performativity of 'New Unitarism'. Journal of Business Ethics, 142, 663678.

Griep, Y. \& Cooper, C. (2019). Introduction. En: Y. Griep \& C. Cooper (eds.). Handbook of research on the psychological contract at work (pp. 1-8). Edward Elgar.

Griep, Y., Cooper, C., Robinson, S., Rousseau, D. R., Hansen, S. D., Tomprou, M. et ál. (2019). Psychological contracts: Back to the future. En: Y. Griep \& C. Cooper (eds.). Handbook of research on the psychological contract at work (pp. 397-414). Edward Elgar.

Griep, Y. \& Vantilborgh, T. (2018). Reciprocal effects of psychological contract breach on counterproductive and organizational citizenship behaviors: The role of time. Journal of Vocational Behavior, 104, 141-153.

Griep, Y., Vantilborgh, T., Hansen, S. D. \& Conway, N. (2018). Editorial: Unravelling the Role of Time in Psychological Contract Processes. Frontiers in Psychology, 9, 813.

Guest, D. E. (1998). Is the psychological contract worth taking seriously? Journal of Organizational Behavior, 19(S1), 649-664.

Guest, D. E. (2004). The psychology of the employment relationship: an analysis based on the psychological contract. Applied Psychology: An International Review, 53, 541-555.

Hansen, S. D. (2019). Psychological contracts: Time for some conceptual clarity. En Y. Griep \& C. Cooper (eds.). Handbook of Research on the Psychological Contract at Work (pp. 63-79). Edward Elgar.

Henderson, D. J., Wayne, S. J., Shore, L. M., Bomme, W. H. \& Tetrick, L. E. (2008). Leader-member exchange, differentiation, and psychological contract fulfillment: A multilevel examination. Journal of Applied Psychology, 93, 1208-1219.

Herriot, P. (1998). "Psychological contract". En: N. Nicholson, (ed.). Blackwell encyclopedic dictionary of organizational behavior (pp. 455-456). Blackwell.

Hiltrop, H.-M. (1995). The changing psychological contract: The human resource challenge of the 1990s. European Management Journal, 13, 286-294. 
Ho, V. T. \& Tekleab, A. G. (2016). A model of idiosyncratic deal-making and attitudinal outcomes. Journal of Managerial Psychology, 31, 642-656.

Hornung, S. \& Rousseau, D. M. (2017). Psychological contracts and idiosyncratic deals: Mapping conceptual boundaries, common ground, and future research paths. En: P. Bhatt, P. Jaiswal, B. Majumdar \& S. Verma (eds.). Riding the new tides: navigating the future through effective people management (pp. 81-91). Emerald.

Hornung, S., Rousseau, D. M. \& Glaser, J. (2009). Why supervisors make idiosyncratic deals: antecedents and outcomes of i-deals from a managerial perspective. Journal of Managerial Psychology, 24, 738-764.

International Labour Organization - ILO (International Labour Force) (2016). Non-standard employment around the world: Understanding challenges, shaping prospects. ILO.

Jensen, J. M., Opland, R. A. \& Ryan, A. M. (2010). Psychological contracts and counter-productive work behaviors: employee responses to transactional and relational breach. Journal of Business and Psychology, 25, 555-568.

Knapp, J. R., Diehl, M.-J. \& Dougan, W. (2020). Towards a social-cognitive theory of multiple psychological contracts. European Journal of Work and Organizational Psychology, 29, 200-214.

Kraak, J. M. \& Linde, B. J. (2019). The usefulness of the psychological contract in the 21st century. En Y. Griep \& C. Cooper (eds.). Handbook of research on the psychological contract at work (pp. 101-121). Edward Elgar.

Kompier, M. A. J. (2006). New systems of work organization and workers' health. Scandinavian Journal of Work, Environment \& Health, 32, 421-430.

Lapalme, M.-E., Simard, G. \& Tremblay, M. (2011). The influence of psychological contract breach on temporary workers' commitment and behaviors: a multiple agency perspective. Journal of Business and Psychology, 26, 311-324.

Lavelle, J., Rupp, D. E. \& Brockner, J. (2007). Multifoci perspectives and target similarity in organizational behavior: bridging justice, commitment, and organizational citizenship behavior. Journal of Management, 33, 378-394.

Lazarus, R. S. \& Folkman, S. (1984). Stress, appraisal, and coping. Springer.

Lester, S. W., Turnley, W. H., Bloodgood, J. M. \& Bolino, M. C. (2002). Not seeing eye to eye: Differences in supervisor and subordinate perceptions of and attributions for psychological contract breach. Journal of Organizational Behavior, 23, 39-56.

Levinson, H., Price, C. R., Munden, K. J. \& Solley, C. M. (1962). Men, management, and mental health. Harvard University Press.

Liao, C., Wayne, S. J. \& Rousseau, D. M. (2016). Idiosyncratic deals in contemporary organizations: a qualitative and meta-analytical review. Journal of Organizational Behavior, 37, S9-S29. 
Luthans, F. \& Youssef-Morgan, C. M. (2017). Psychological capital: an evidence-based positive approach. Annual Review of Organizational Psychology and Organizational Behavior, $4,339-366$.

Malhotra, D. \& Murnighan, J. K. (2002). The effects of contracts on interpersonal trust. Administrative Science Quarterly, 47, 534-559.

Marks, A. (2001). Developing a multiple foci conceptualization of the psychological contract. Employee Relations, 23, 454-467.

Masterson, S. S., Lewis, K., Goldman, B. M. \& Taylor, M. S. (2000). Integrating justice and social exchange: the differing effects of fair work procedures and treatment on work relationships. Academy of Management Journal, 43, 738-48.

Morrison, E. W. \& Robinson, S. L. (1997). When employees feel betrayed: A model of how psychological contract violation develop. Academy of Management Review, 22, 226-256.

O’Leary-Kelly, A. M., Henderson, K. E., Anand, V. \& Ashforth, B. E. (2014). Psychological contracts in a nontraditional industry: Exploring the implications for psychological contract development. Group \& Organization Management, 9, 326-360.

Parzefall, M. R. \& Coyle-Shapiro, J. A. (2011). Making sense of psychological contract breach. Journal of Managerial Psychology, 26, 12-27.

Petersitzke, M. (2009). Theoretical basis of psychological contracts. En M. Petersitzke (ed.). Supervisor Psychological Contract Management. Developing an Integrated Perspective on Managing Employee Perceptions of Obligations (pp. 61-90). Springer Gabler.

Raeder, S. (2018). Psychological contracts of multiple jobholders: a multilevel analysis. Sage Open, 8, 1-18.

Raja, U., Johns, G. \& Ntalianis, F. (2004). The impact of personality on psychological contracts. Academy of Management Journal, 47, 350-367.

Restubog, S. L. D., Zagenczyk, T. J., Bordia, P., Bordia, S. \& Chapman, G. J. (2015). If you wrong us, shall we not revenge? Moderating roles of self-control and perceived aggressive work culture in predicting responses to psychological contract breach. Journal of Management, 41, 1132-1154.

Robinson, S. L. \& Morrison, E. W. (2000). The development of psychological contract breach and violation: a longitudinal study. Journal of Organizational Behavior, 21, 525-546.

Robinson, S. L. \& Rousseau, D. M. (1994). Violating the psychological contract: not the exception but the norm. Journal of Organizational Behavior, 15, 245-259.

Rodrigues, R. A. \& Guest, D. (2010). Have careers become boundaryless? Human Relations, 63, 1157-1175.

Rosen, C. C., Slater, D. J., Chang, C.-H. \& Johnson, R. E. (2013). Let's make a deal: development and validation of the ex post i-deals scale. Journal of Management, 39, 709-742.

Rousseau, D. M. (1989). Psychological and implicit contracts in organizations. Employee Responsibilities and Rights Journal, 2, 121-139. 
Rousseau, D. M. (1990). New hire perceptions of their own and employer's obligations: A study of psychological contracts. Journal of Organizational Behavior, 11, 389-400.

Rousseau, D. M. (1995). Psychological contracts in organizations: understanding written and unwritten agreements. Sage.

Rousseau, D. M. (1998). The 'problem' of the psychological contract considered. Journal of Organizational Behavior, 19, 665-671.

Rousseau, D. M. (2001). Schema, promise and mutuality: The building blocks of the psychological contracts. Journal of Occupational and Organizational Psychology, 74, 511-541.

Rousseau, D. M. (2005). I-deals, idiosyncratic deals employees bargain for themselves. M. E. Sharpe.

Rousseau, D. M., Ho, V. T \& Greenberg, J. (2005). I-deals: idiosyncratic terms in employment relationships. Academy of Management Review, 31, 977-994.

Rousseau, D. M. \& Tijoriwala, S. A. (1998). Assessing psychological contracts: issues, alternatives, and measures. Journal of Organizational Behavior, 19, 679-698.

Rousseau, M. D., Tomprou, M. \& Hansen, D. S. (2018). A dynamic phase model of psychological contract processes. Journal of Organizational Behavior, 39, 1081-1098.

Schalk, R. \& Roe, R. E. (2007). Towards a dynamic model of the psychological contract. Journal for the Theory of Social Behaviour, 37, 167-182.

Schalk, R., De Ruiter, M., Van Loon, J., Kuijpers, E. \& Van Regenmortel, T. (2018). Actively coping with violation: exploring upward dissent patterns in functional, dysfunctional, and deserted psychological contract end states. Frontiers in Psychology, 9, 54.

Schein, E. H. (1965). Organizational psychology. Prentice Hall.

Shore, M. L., Coyle-Shapiro, J. A.-M. \& Tetrick, L. E. (2012). Expanding the boundaries and challenging the assumptions of the employee-organization relationship literature. In M. L. Shore, J. A.-M. Coyle-Shapiro \& L. E. Tetrick (eds.). The employee-organization relationship. applications for the 21st century (pp. 1-19). Routledge.

Shore, L., Tetrick, L., Taylor, M., Coyle Shapiro, J., Liden, R., McLean Parks, J., Wolfe Morrison, E., Porter, L., Robinson, S., Roehling, M., Rousseau, D., Schalk, R., Tsui, A. \& Van Dyne, L. (2004). The employee-organization relationship: A timely concept in a period of transition. En: G. Ferris \& J. Martocchio (eds.). Research in personnel and human resources management (vol. 23, pp. 291-370). Emerald Group Publishing.

Tomprou, M., Hansen, D. S. \& Rousseau, M. D. (2015). The psychological contracts of violation victims: a post-violation model. Journal of Organizational Behavior, 36, 561-581.

Turnley, W. H. \& Feldman, D. C. (1999). The impact of psychological contract violations on exit, voice, loyalty, and neglect. Human Relations, 52, 895-922.

Vidyarthi, P. R., Chaudhry, A., Anand, S. \& Liden, R. C. (2014). Flexibility i-deals: how much is ideal? Journal of Managerial Psychology, 29, 246-265. 
Zaleska, K. J. \& de Menezes, L. M. (2007). Human resources development practices and their association with employee attitudes: Between traditional and new careers. Human Relations, 60, 987-1018.

Zhao, H. A. O., Wayne, S. J., Glibkowski, B. C. \& Bravo, J. (2007). The impact of psychological contract breach on work-related outcomes: a meta-analysis. Personnel Psychology, 60, 647-680. 

de Colombia

Vigilada Mineducación

Sapientia aedificavit sibi domun

Editado por la Universidad Católica de Colombia en diciembre de 2020, en tipografía Minion Pro, tamaño 11 pts.

Publicación digital

Hipertexto Ltda.

Bogotá, D. C., Colombia 


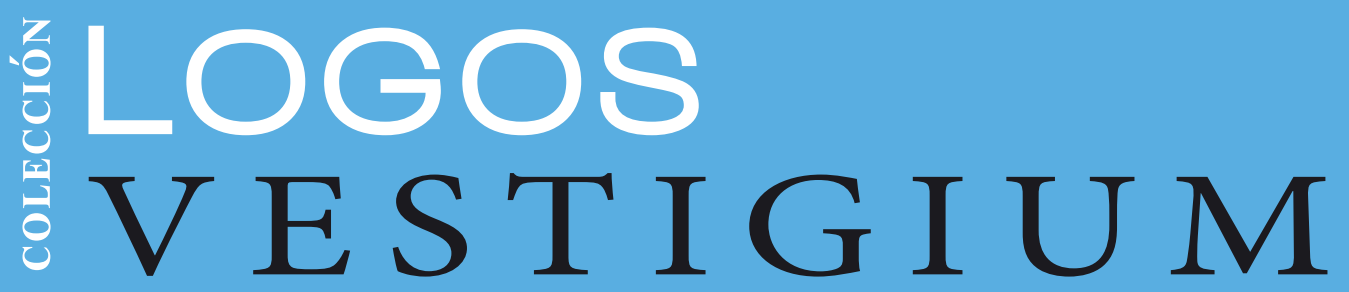

La vigencia del contrato psicologico Aproximaciones tebricas y empiricas desde las Américas
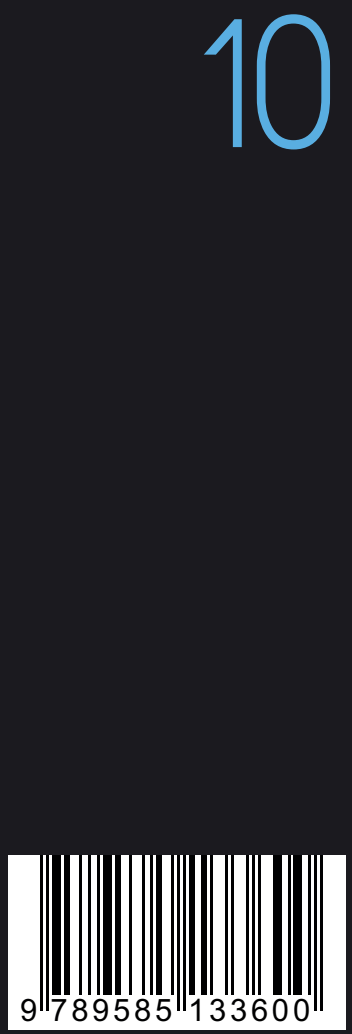

Los continuos cambios que caracterizan el mundo del trabajo y las relaciones laborales en la actualidad modifican de formas diversas las percepciones, las expectativas y las creencias de los trabajadores y los empleadores acerca del contenido y el cumplimiento de sus relaciones de intercambio, las cuales configuran los contratos psicológicos.

Este libro tiene como objetivo ofrecer una panorámica de la diversidad que caracteriza la reflexión conceptual y la investigación sobre el contrato psicológico realizadas desde varios países de las Américas. Investigadores e investigadoras de Colombia, Puerto Rico, México, Brasil, Canadá y España presentan un conjunto de trabajos teóricos y empíricos que tratan de profundizar en la comprensión de las relaciones empleado-organización en los múltiples contextos de trabajo de los respectivos países, y representa una valiosa aportación a la investigación en psicología de las organizaciones y del trabajo en estos contextos. 